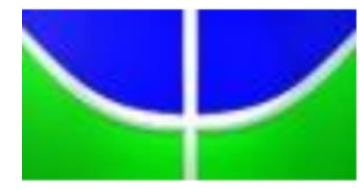

UNIVERSIDADE DE BRASÍLIA

INSTITUTO DE LETRAS

DEPARTAMENTO DE LINGUÍSTICA, PORTUGUÊS E LÍNGUAS CLÁSSICAS PROGRAMA DE PÓS-GRADUAÇÃO EM LINGUÍSTICA

\title{
A REDAÇÃO NAS SÉRIES FINAIS DO ENSINO FUNDAMENTAL: DA ANÁLISE DE ERROS ÀS ESTRATÉGIAS DIDÁTICAS
}




\title{
A REDAÇÃO NAS SÉRIES FINAIS DO ENSINO FUNDAMENTAL: DA ÂNÁLISE DE ERROS ÀS ESTRATÉGIAS DIDÁTICAS
}

\author{
Tese apresentada ao Programa de Pós-Graduação em \\ Linguística, do Departamento de Linguística, Português e \\ Línguas Clássicas, da Universidade de Brasília, como \\ requisito parcial para obtenção do Grau de Doutor em \\ Linguística, Área de concentração: Teoria e Análise \\ Linguística.
}

Orientadora: Prof. ${ }^{a}$. Doutora Daniele Marcelle Grannier 
Priscilla da Silva Santos

\section{A REDAÇÃO NAS SÉRIES FINAIS DO ENSINO FUNDAMENTAL: DA ANÁLISE DE ERROS ÀS ESTRATÉGIAS DIDÁTICAS}

Tese apresentada ao Programa de Pós-Graduação em Linguística, do Departamento de Linguística, Português e Línguas Clássicas, da Universidade de Brasília, como requisito parcial para obtenção do Grau de Doutor em Linguística, Área de concentração: Teoria e Análise Linguística.

BANCA EXAMINADORA

Prof. ${ }^{\text {a }}$ Dra. Daniele Marcelle Grannier (Orientadora)

Programa de Pós-Graduação em Linguística (PPGL/UnB)

Prof. ${ }^{a}$. Dra. Andrea Lima Belfort Duarte (Membro Externo)

Faculdade de Letras - Universidade Federal do Rio de Janeiro

Profa. Dra. Patrícia Maria de Campos Almeida (Membro Externo)

Faculdade de Letras - Universidade Federal do Rio de Janeiro

Profa. Dra. Marcia Elizabeth Bortoni (Membro Interno)

Programa de Pós-Graduação em Linguística (PPGL/UnB)

Profa. Dra. Ulisdete Rodrigues

Instituto de Letras (LIP/UnB)

Prof. ${ }^{a}$. Doutora Poliana M. Alves

Instituto de Letras (LIP/UnB) 
Ficha Catalográfica

Santos, Priscilla

SSA237 A redação nas séries finais do ensino fundamental:

r da análise de erros às estratégias didáticas. / Priscilla Santos; orientador Daniele Marcelle Grannier. -- Brasilia, 2015. $218 \mathrm{p}$.

Tese (Doutorado - Doutorado em Linguística) -Universidade de Brasilia, 2015.

1. Usage-based Linguistic. 2. Ensino de produçăo de texto no sexto ano. 3. Argumentação no sexto ano. 4. Pontuação e prosódia. 5. Gramática e uso da língua I. Grannier, Daniele Marcelle, orient. II. Título. 
Ao desassossego que mudou meu endereço e minha vida, em busca de sonhos inquietantes.

À persistência que, mesmo frágil, me trouxe até o fim. Aos seres iluminados, deste e de outros mundos, que agiram de forma que desassossego e persistência fizessem sentido, e valessem as penas desse longo caminho. 


\section{AGRADECIMENTOS}

A Alfredo, meu pai e herói, pelo amor, pelo apoio irrestrito às minhas escolhas, pelos ensinamentos e presença em minha jornada.

A Delza, minha mãe e estrela, pelo amor incondicional.

À Patrícia, minha pessoa, por ser meu porto, minha base, minha irmã.

A meu irmão Gabriel, pelo apoio e por suportar, com amor, minha ausência.

À professora Daniele Grannier, pela acolhida e por todos os ensinamentos preciosos ao longo dessa jornada.

A todos os docentes do PPGL, pelo primoroso suporte acadêmico que me proporcionaram ao longo de todo o processo de doutoramento.

Aos funcionários do PPGL, especialmente a Ângela e Renata, pela eficiência e competência desde o primeiro contato com o Programa, em 2009.

Às professoras Andrea Duarte, Patrícia Almeida, Márcia Bortoni, Poliana Alves e Ulisdete Rodrigues, por aceitarem compor a banca de Defesa de Tese.

À CAPES, pelo importante período em que fui bolsista REUNI.

À Universidade de Brasília, por ter me dado condições de trilhar o percurso acadêmico que escolhi, e por todas as oportunidades que esse centro de referência trouxe à minha vida.

À Universidade Federal do Rio de Janeiro, minha base acadêmica.

A Brasília, por tudo que tem me proporcionado desde que aqui cheguei.

A Naiara Clemente e alunos, por terem viabilizado a realização desta pesquisa ao confiarem na seriedade do meu trabalho investigativo.

Aos amigos, de lá, de cá e de acolá, que me encorajaram, auxiliaram, deram suporte, riram, choraram e chegam comigo, apesar de toda ausência, ao fim dessa jornada. jornada.

A Alessandra e Theo Harden, pelo apoio imensurável nos últimos momentos dessa

À família Chiari-Rocha, pelo apoio e carinho desde minha chegada a essas terras secas do cerrado brasileiro.

À família Motta, pela acolhida e pelo apoio desde que cheguei a suas vidas.

A Daniel, por chegar, ficar e continuar ao meu lado.

A Amora e Cereja, por alegrarem minha vida e pela companhia incondicional.

À incrível Shonda Rhimes e suas criações, médicos do atual Grey+Sloan Memorial Hospital, meus companheiros desde o mestrado, e que foram fundamentais nesses anos de doutorado. 
"Meaning is use" "Structure emerges from use".

Tomasello (2008: 69)

“The carrousel never stops turning”.

Grey's Anatomy, Episódio 21, Temporada 11. 


\section{RESUMO}

A presente tese tem como objeto de análise produções de textos argumentativos de alunos do sexto ano, de uma escola privada de Brasília, sob a perspectiva teórica da Usage-Based Linguistic, com base nos estudos de Bybee, Tompson, Tomasello e, no Brasil, Martelotta, Bispo e Cunha. A escolha teórico-metodológica foi baseada na necessidade de se analisar a língua escrita em uso pelos alunos, a fim de se buscar novas estratégias para o ensino de Produção de Texto. A partir desses pontos, objetivou-se (i) mapear os principais problemas de estrutura do texto argumentativo produzidos por alunos do sexto ano; (ii) analisar a compreensão dos alunos acerca da organização de textos argumentativos escritos, (iii) verificar em que medida a língua falada influencia na organização do texto escrito, quando se exige o uso da norma-padrão da língua; e (iv) observar a influência da prosódia da língua falada sobre a organização textual escrita em casos específicos de uso da vírgula. A pesquisa conta com a análise de três corpora, formados por um questionário aplicado aos alunos, 150 produções de textos e o áudio de um programa de rádio, para se comparar, acusticamente, a prosódia e o uso de vírgulas nos textos escritos. Os dados gerados por esses instrumentos foram submetidos à análise qualitativa e têm suporte para as discussões propostas na análise quantitativa. Além de descrição, análise e discussão dos dados à luz da Usage-Based Linguistic, esta pesquisa discute questões relacionadas ao ensino de Língua Portuguesa e Produção Textual, e propõe intervenções didáticas a partir dos resultados obtidos na análise de dados. Os corpora indicaram que o aluno domina, como conhecimento prévio à vida escolar, a norma padrão na linguagem escrita em alguma medida, e à escola cabe adequar esse saber à norma padrão da língua portuguesa nas produções escritas dos estudantes. Além disso, no que diz respeito à relação entre entonação e pontuação, as análises põem em cheque algumas afirmações clássicas sobre o assunto, como a relação entre uso da vírgula e a pausa. Com base nos resultados encontrados, foram feitas propostas didáticas para o ensino de Produção de Texto e Língua Portuguesa, no sexto ano. Por sua natureza analítica em relação à estrutura da língua, esta pesquisa se enquadra nos estudos referentes à Teoria e Análise Gramatical, e visa propor incremento ao ensino de Produção Textual a partir da intervenção docente efetiva na língua em uso pelo aluno de sexto ano.

Palavras-Chave: Usage-Based Liguistic. Análise gramatical baseada no uso. Produção de textos. Relação entre Prosódia e uso da vírgula no texto escrito. Ensino de Língua Portuguesa para o sexto ano. 


\begin{abstract}
The present thesis will analyze the production of argumentative texts of sixth grade students from a private school in Brasilia, under the theoretical perspective of the Usage-Based Linguistic, based on the studies of Bybee, Tompson, Tomasello and, in Brazil of Martelotta, Bispo and Cunha. The theoretical methodological choice was based on the need to analyze the written language in use by students, in order to pursue new strategies for the teaching of text production. Based on such points, the objective was (i) to map the main problems of argumentative text structure produced by sixth grade students; (ii) to analyze the comprehension of the students regarding the organization of written argumentative texts; (iii) to verify the extent to which the spoken language influences the written text organization, when it requires the usage of the Standard Language; and (iv) to observe the influence of the prosody of spoken language on the written textual organization in specific cases of comma usage. The research includes the analysis of three corpora, formed by a questionnaire applied to the students, 150 text productions and an audio of a radio program to make an acoustically comparison between the prosody and the use of comma in the written texts. The data generated by such instruments were subjected to qualitative analysis and has the support for the discussions proposed in the quantitative analysis. Besides the description, analyses and discussion of the data based on the Usage-Based Linguistic, such research discusses issues related to the Portuguese Language teaching and Textual Production and it proposes educational interventions from the results obtained in data analysis. The corpora indicated that the student dominates, as prior knowledge to school life, the written Standard Language to a certain extent, and it is the responsibility of the school to adapt such knowledge to the Portuguese Standard Language in the written production of the students. Furthermore, regarding the relation between intonation and punctuation, the analyzes challenge some classic statements on the subject, as the relation between the use of comma and the pause itself. Based on the results found, educational proposals were made to the text production teaching and Portuguese Language in the sixth grade. Per its analytical nature in relation to language structure, such research falls inside the studies on the Theory and Analysis of Grammar, and it aims to propose an increase to the Textual Production from the effective teaching intervention in the language in use by the student of the sixth grade.
\end{abstract}

Key words: Usage-Based Linguistic. Grammar analyses based on the usage. Textual Production. The relation between prosody and the use of comma in written texts. Teaching of Portuguese language for the sixth grade. 


\section{ZUSAMMENFASSUNG}

Die vorliegende Dissertation hat die Zielsetzung, die Produktion argumentativer Texte durch Schüler der sechsten Jahrgangsstufe einer Privatschule in Brasília zu analysieren. Der theoretische Rahmen für die Untersuchung ist Usage-Based-Linguistic auf der Grundlage der Arbeiten von Bybee, Tompson, Tomasello und der brasilianischen Beiträge von Martelotta, Bispo und Cunha. Die Auswahl dieses Rahmens ergab sich durch die Notwendigkeit der Analyse schriftlicher Schüleräußerungen mit dem Ziel, neue Strategien für die Produktion von Texten im schulischen Kontext zu finden. Auf dieser Grundlage ergeben sich die folgenden Frage- und Problemstellungen: a) Inventarisierung und Lokalisierung der grundsätzlichen Schwierigkeiten von Schülern der sechsten Jahrgangsstufe bei der Produktion von Texten; b) Analyse des Verständnisniveaus der Schüler bezüglich der Organisation schriftlicher argumentativer Texte; c) Bestandsaufnahme der Einflüsse der gesprochenen Sprache innerhalb eines normativen Kontexts; d) Beobachtung prosodischer Einflüsse auf die Verwendung von Kommata. Grundlage der Untersuchung sind drei Corpora: ein Fragebogen, 150 Textproduktionen und ein Radioprogramm um die Verwendung von Kommata in der geschriebenen Sprache zu überprüfen. Die aus diesen Corpora gewonnenen Daten wurden einer qualitativen Anlyse unterzogen und sie werden durch die Vorschläge, die innerhalb der Diskussion der quantitativen Analyse gemacht wurden, unterstiutzt.

Neben der Beschreibung, Diskussion und Analyse der Daten im Lichte der Usage-BasedLinguistic werden zudem Probleme des muttersprachlichen Portugiesischunterrichts im Allgemeinen und der Texproduktion in diesem Kontext im Speziellen thematisiert, wobei auf der Base der vorliegenden Daten bestimmte didaktische Interventionen vorgeschlagen werden. Die Corpora lassen den Schluss zu, dass die Schüler durchaus über eine gewisse Kenntnis der Standardsprache und der geforderten Normen verfügen, dass es jedoch Aufgabe der Schule ist, diese Kenntnisse auf das entsprechende Niveau zu heben. Hinsichtlich des Verhältnisses zwischen Intonation und Zeichensetzung lassen die erhobenen Daten Zweifel an einigen klassischen Annahmen zu, dienen aber auch als Grundlage für eine Reihe von didaktischen Vorschlägen bezüglich der Produktion von Texten im sechsten Schuljahr. Wegen der analytischen Natur dieser arbeit, positioniert sie ich innerhalb der grammatischen Analyse und Theorie und versucht, Vorschläge für eine Verbesserung der Textproduktion durch die effiziente Intervention von Seiten der Lehrer zu machen.

Schlagwörter: Usage-Based-Linguistc, grammatische Analyse auf Grundlage des Gebrauchs, Texproduktion, Verhältnis zwischen Prosodie und der Setzung von Kommata im schriftlichen Sprachgebrauch, muttersprachlicher Unterricht des Portugiesischen im sechsten Schuljahr. 


\section{SUMÁRIO}

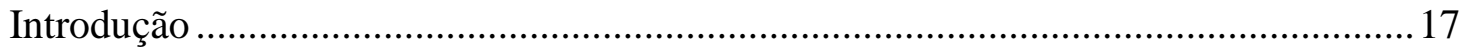

Capítulo 1 - A base teórica: questões sobre linguística ..........................................24

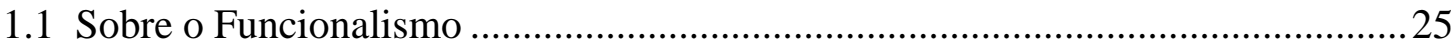

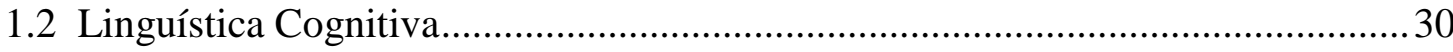

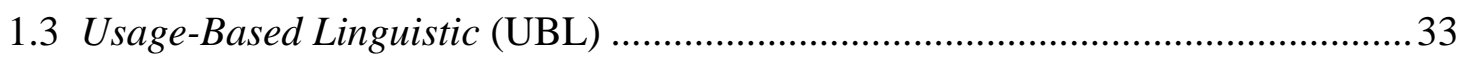

1.3.1 Usage-Based Phonology (Fonologia baseada no uso)..................................... 35

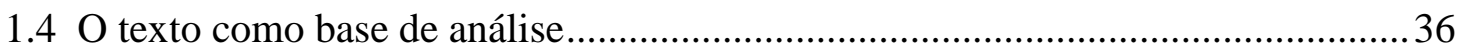

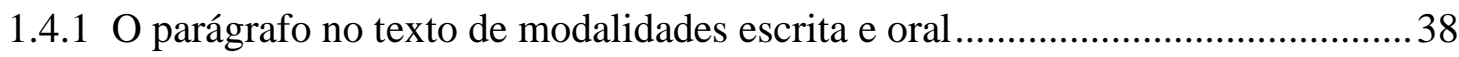

1.4.2 O parágrafo no ensino de Língua Inglesa para o sexto ano ..............................46

1.4.3 O parágrafo no ensino de Língua Portuguesa para o sexto ano..........................50

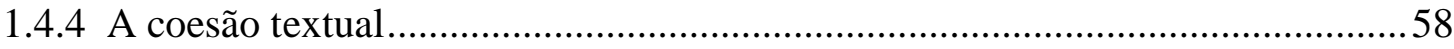

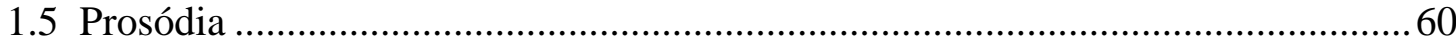

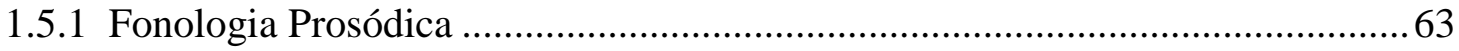

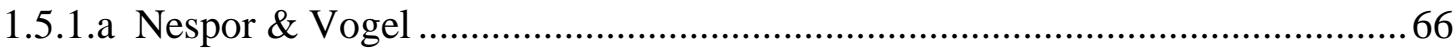

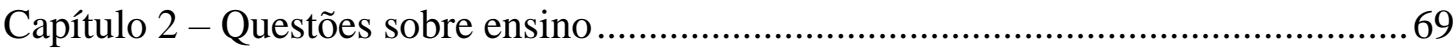

2.1 Parâmetros Curriculares Nacionais - alguns princípios norteadores do ensino de



2.2 Base Nacional Comum Curricular .................................................................. 74

2.3 A pontuação em Língua Portuguesa .................................................................... 83

2.4 Matrizes de correção das produções de texto - ENEM e CEBRASPE .................. 90

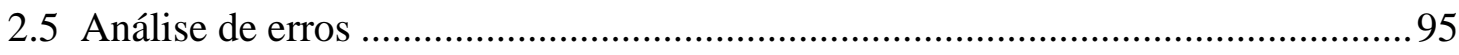



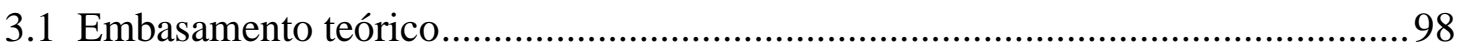

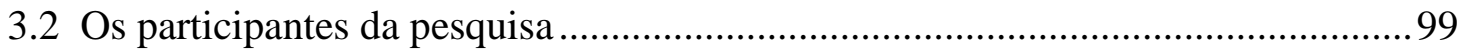

3.3 A construção do corpora de análise ................................................................. 100 
3.3.1 Produção de textos argumentativos pelos alunos do sexto ano da Escola Internacional

3.3.2 Questionário - Instrumento de pesquisa e constituição de corpus I............. 105

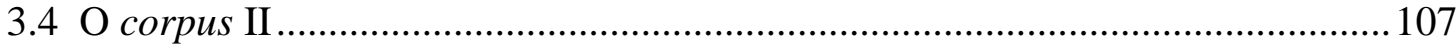

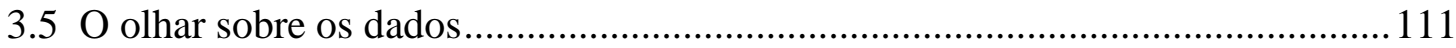

3.5.1 Corpus III - análise acústica de áudio e sua comparação com dados do corpus II

Capítulo 4 - Descrição e análise dos corpora ……………........................................... 118



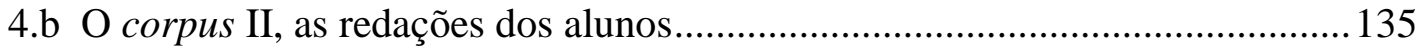

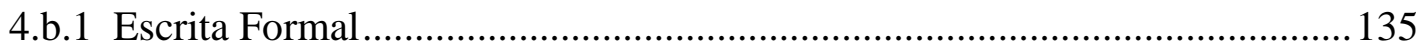

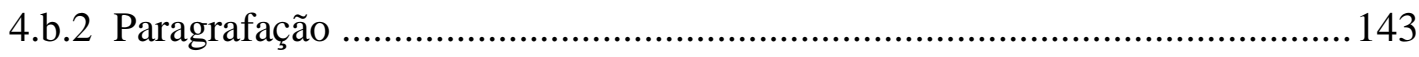

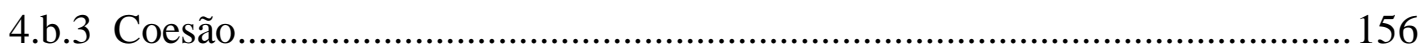

4.b.4 Pontuação - comparação entre os dados escritos e o corpus III.................... 169

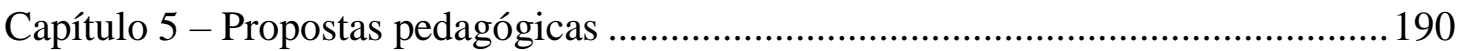

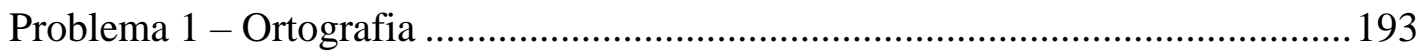

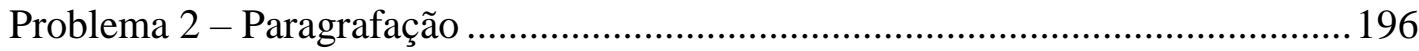

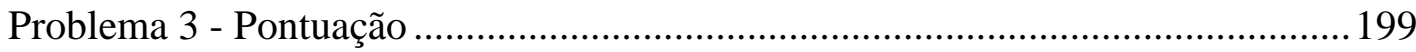

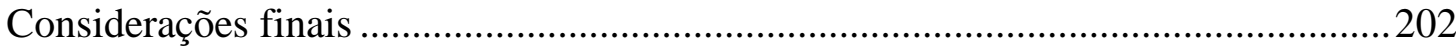

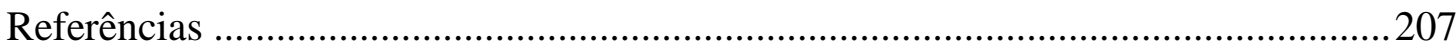

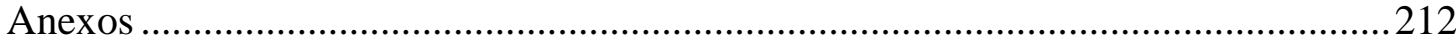

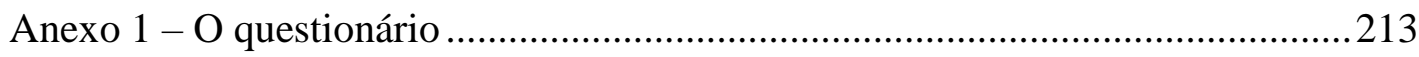



Anexo 3 - Tabela de Critérios de Análise dos dados ...........................................2218 


\section{LISTA DE FIGURAS}

Figura 1 - O papel da entonação: pergunta ou afirmação? .................................................. 37

Figura 2 - Write source, a book for writing, thinking, and learning, página 219 .................. 48

Figura 3-Write source, a book for writing, thinking, and learning - página 220................. 49

Figura 4 - Guia de Livros Didáticos PNLD 2014, página 75 ..............................................51

Figura 5 - Livro didático "Para viver juntos", para o sexto ano, 2014, página 140...............53

Figura 6-Livro didático "Para viver juntos", para o sexto ano, 2014, página 141...............54

Figura 7 - Livro didático "Para viver juntos", para o sexto ano, 2014, página 260...............55

Figura 8 - Livro didático "Para viver juntos", para o sexto ano, 2014, página 277...............57

Figura 9-Hierarquia Prosódica segundo Nespor \& Vogel, 1986.........................................64

Figura 10 - Comparação de hierarquia de constituintes prosódicos. Pacheco, 2006: 56 ........65

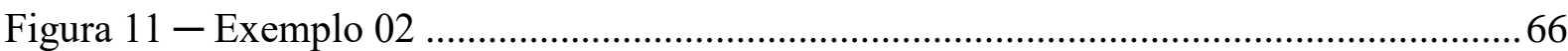

Figura 12 - Brasil, 1998:49. O que se espera do aluno no processo de escuta de textos orais.

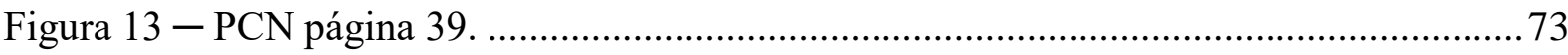

Figura 14 - Base Nacional Curricular Comum - página 8. ................................................. 75

Figura 15 - Base Nacional Curricular Comum - página 8. ............................................... 75

Figura 16 - Base Nacional Curricular Comum - página 9. …............................................ 76

Figura 17 - Base Nacional Curricular Comum - página 35 ................................................. 77

Figura 18 - Base Nacional Curricular Comum - página 35 . .............................................. 78

Figura 19 - Base Nacional Curricular Comum - página 43. ................................................. 79

Figura 20 - Base Nacional Curricular Comum - página 44. ................................................ 79

Figura 21 - Base Nacional Curricular Comum - página 65................................................ 80

Figura 22 - Base Nacional Curricular Comum - página 66. .............................................. 81

Figura 23 - Base Nacional Curricular Comum - página 68. .............................................. 81

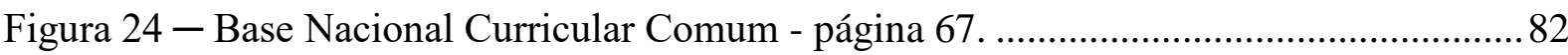

Figura 25 - Guia do Participante - ENEM 2013, página 8 ................................................. 91

Figura 26 - Guia do Participante - ENEM 2013, página 12 .............................................. 92

Figura 27 - Critérios de avaliação dos aspectos microestruturais - CEBRASPE. ..................94

Figura 28 - Critérios de avaliação dos dados ...................................................................... 108

Figura 29 - O que se observar na análise acústica do programa PRAAT ............................ 116

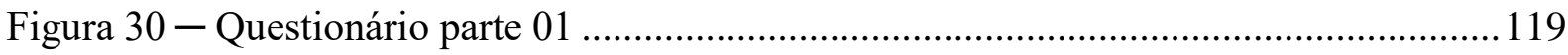




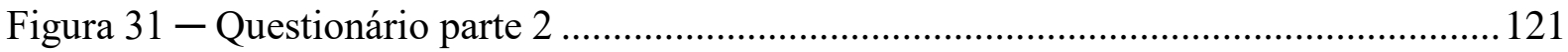

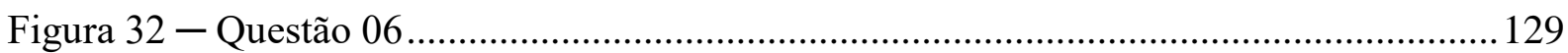

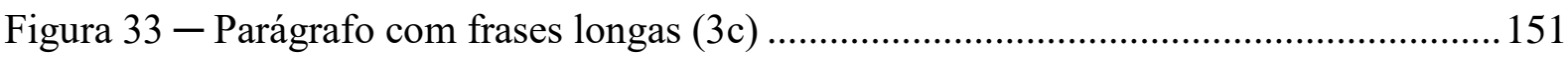

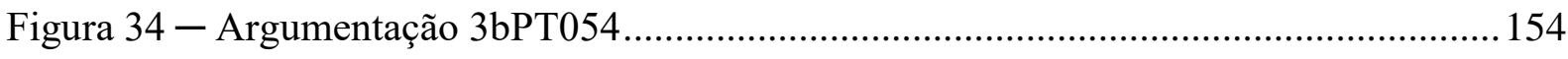

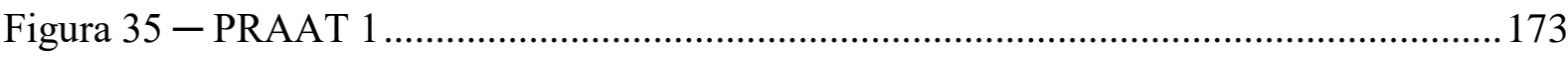

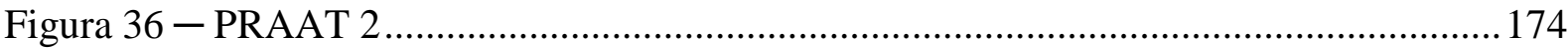

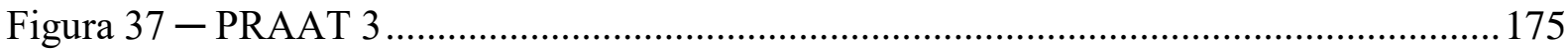

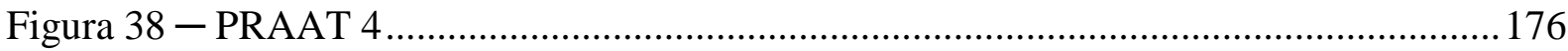

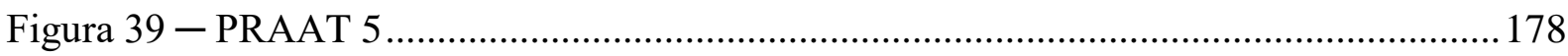

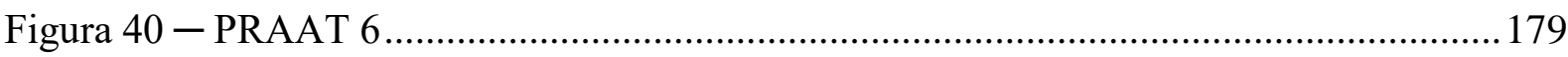

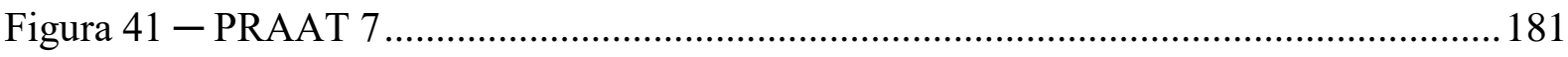



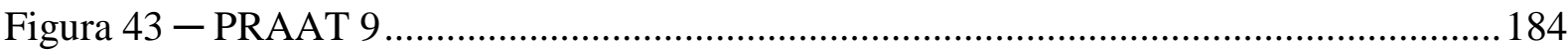



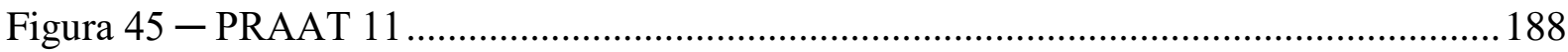

Figura 46 - Uso, Reflexão, Intervenção, Uso. Esquema................................................. 192

Figura 47 - Base Nacional Curricular Comum - páginas 48 e 49. ....................................... 194

Figura 48 - Exemplo de Paragrafação, Aluno 1, Etapa 1................................................... 196

Figura 49 - Proposta Didática: paragrafação 1 ..................................................................... 197

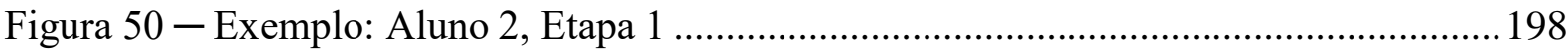

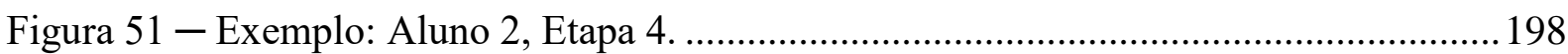

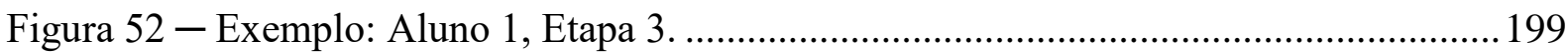

Figura 53 - Livro didático "Para viver juntos", para o sexto ano, 2014, página 8..............216

Figura 54 - Livro didático "Para viver juntos", para o sexto ano, 2014, página 9...............217 


\section{LISTA DE GRÁFICOS}

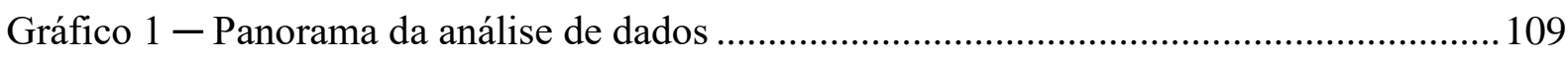

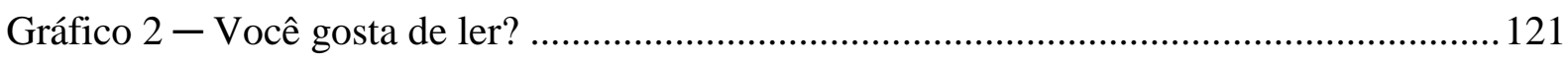

Gráfico 3 - Questionário - Você gosta de produzir textos?................................................ 122

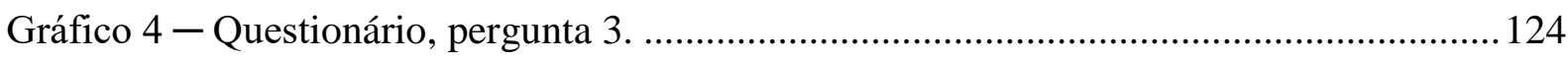

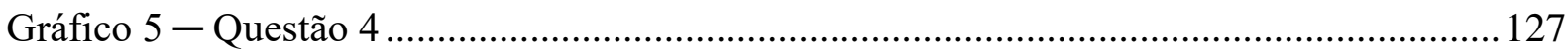

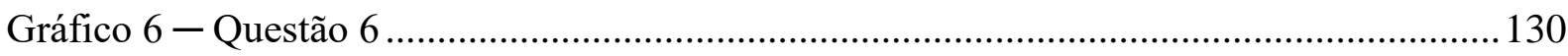

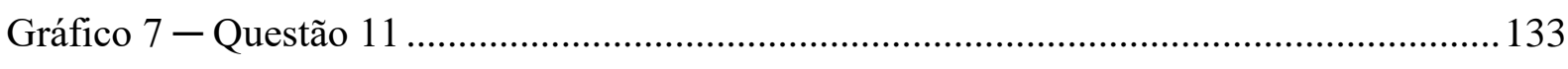

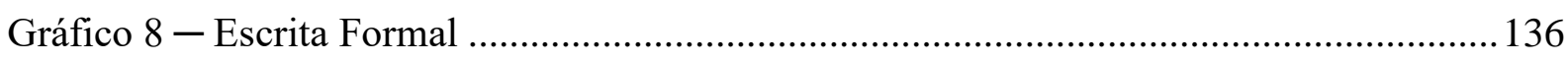

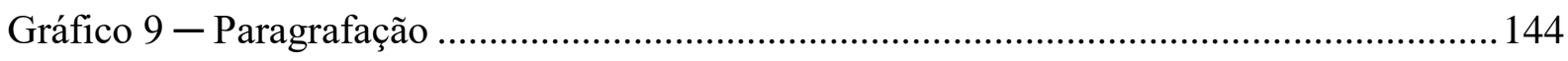

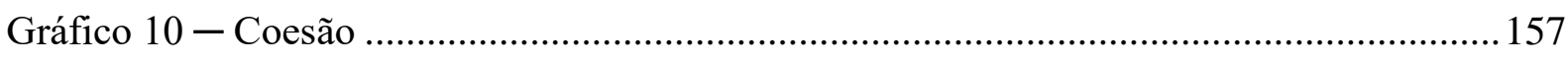

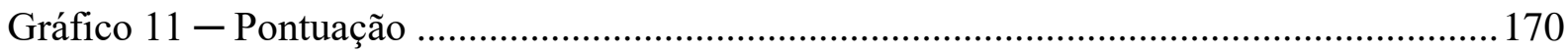




\section{LISTA DE TABELAS}

Tabela 1-Coesão referencial e coesão sequencial entre os critérios de análise dos dados.....59

Tabela 2 - Situações de uso da vírgula, por Abreu, 2003 .................................................. 85

Tabela 3 - A vírgula segundo quatro gramáticas tradicionais............................................... 89

Tabela 4 - Trascrição de áudio "Caderninho da Bel".......................................................... 115

Tabela 5 - Hipo e Hiperssegmentação nos dados - ocorrências do sexto ano ....................... 138 


\section{Introdução}

Todo ano, jornais brasileiros noticiam os resultados do Exame Nacional do Ensino Médio (ENEM), que é uma das principais formas de acesso ao Ensino Superior na atualidade. Polêmica a respeito do exame, frequentemente, acontece em relação às notas de redação. No ENEM $2014^{1}$, o que chamou a atenção de diversas mídias de informação foram as 529 mil notas zero, contrastando com as 250 notas mil, ou seja, notas máximas.

Em setembro de 2015, o Ministério da Educação (MEC) divulgou as notas na Avaliação Nacional da Alfabetização (ANA), que avalia o desempenho de alunos do terceiro ano do Ensino Fundamental I nas competências de leitura, escrita e matemática. Os resultados, segundo dados do próprio relatório ${ }^{2}$ e de notícias ${ }^{3}$ veiculadas na mídia, indicam que 56,17\% dos alunos alcançaram níveis mínimos de leitura e que $34,46 \%$ produzem textos de forma "incipiente ou inadequada", em palavras da escala de escrita do próprio documento.

Esses dados são alguns dos vários índices de avaliações em escala nacional e (ou) internacional que fazem soar o alarme da educação brasileira, apontando que a direção tomada até agora está errada. Os dados, ainda, refletem a educação brasileira no que diz respeito ao ensino de Língua Portuguesa e justificam o descontentamento de alguns professores com a docência.

A dificuldade que o aluno tem para produzir textos, evidenciada acima, foi a propulsora da pesquisa ora apresentada. A prática docente da pesquisadora - lecionou a disciplina de Leitura e Produção de Textos em algumas instituições privadas de Brasília, participou, entre 2010 e 2014, da correção da redação de exames de seleção e avaliação de larga escala e atou como docente no Ensino Fundamental II - despertou seu interesse para a competência escritora, e motivou a investigação empreendida com alunos do sexto ano.

\footnotetext{
1 Conferir notícia em: http://g1.globo.com/educacao/noticia/2015/01/529-mil-alunos-obtiveram-nota-zero-naredacao-do-enem-2014-diz-mec.html (acesso em 20 de set. 2015) ou http://educacao.uol.com.br/noticias/2015/01/13/529-mil-candidatos-tiraram-zero-na-redacao-do-enem-2014.htm (acesso em 20 de set. 2015).

2 Conferir em http://portal.mec.gov.br/index.php?option=com_docman\&view=download\&alias=21091apresentacao-ana-15-pdf\&category_slug=setembro-2015-pdf\&Itemid=30192 (acesso em 20 de set. 2015)

3 Conferir em http://noticias.universia.com.br/destaque/noticia/2015/09/18/1131401/mec-divulga-avaliacaonacional-alfabetizacao.html (acesso em 20 de set. 2015) ou http://g1.globo.com/bom-diabrasil/noticia/2015/09/pesquisa-revela-numeros-criticos-da-alfabetizacao-no-brasil.html (acesso em 20 de set. 2015)
} 
Os participantes do ENEM, que serão os ingressantes em universidades privadas e públicas, completaram todo o percurso da Educação Básica, na qual o indivíduo é exposto à prática da escrita de redações e trabalhos para seus professores. Assim, como justificar resultados tão negativos quanto os vistos no ENEM? A resposta para essa indagação é inexata, mas, certamente, está relacionada aos resultados relativos à ANA, entre outras questões ligadas à qualidade do ensino brasileiro. Quando o tema é a qualidade das produções de texto, a experiência, até agora, indica que os resultados obtidos não estão relacionados ao sistema de ensino, escola pública ou escola privada. Os dados relativos ao Exame indiciam que o desempenho de parte dos estudantes, nas produções de texto, parece não condizer com o esperado para os concluintes do Ensino Médio.

Diante do contexto apresentado, optou-se por investigar a produção de textos no sexto ano, momento de transição do Ensino Fundamental I para o Ensino Fundamental II. Nessa fase, os resultados do processo de aprendizagem até o quinto ano são evidenciados e os conteúdos vistos até então são aprofundados. Além disso, no sexto ano, os alunos começam a ter contato com uma nova forma de enxergar os conteúdos, na qual se espera que eles aprendam a olhá-los verticalmente. Por essas e outras questões é que se deve pensar o sexto ano como o momento de tentar alterar aqueles resultados negativos do público avaliado pela ANA, e preparar o terreno para a obtenção de menos notas zero na redação do ENEM, além de uma quantidade maior de notas mil.

Outro ponto a se considerar, para compreender a gênese deste trabalho, é que a atuação profissional da pesquisadora com níveis de ensino em que o público-alvo era os concluintes da Educação Básica fez com que ela se deparasse com produções de texto ricas em problemas estruturais, compatíveis aos resultados das avaliações mencionados anteriormente. Isso gerou, na pesquisadora, o desejo de trabalhar com as séries iniciais do Ensino Fundamental II, a fim de tentar identificar a essência dos problemas de escrita e intervir de forma a contribuir para a melhoria do desempenho dos alunos em suas redações.

As produções de texto dos alunos em nível final da Educação Básica indicavam uma forte interferência da língua falada na organização dos textos escritos, indiciando que o processo de ensino teria falhado ao longo do percurso escolar. Documentos oficiais relacionados à educação, como os Parâmetros Curriculares Nacionais (PCN) e Base Nacional Curricular Comum (BNCC), enfatizam que o aluno chega à escola já dominando o uso da língua oral e que, portanto, à escola cabe o ensino da norma padrão escrita, o que tem sido feito de forma, aparentemente, pouco eficaz. 
Dessa forma, decidiu-se investigar as produções de texto de alunos do sexto ano, a fim de se (i) mapear os principais problemas de estrutura do texto argumentativo produzidos por alunos do sexto ano (análise de erros); (ii) analisar a compreensão dos alunos acerca da organização de textos argumentativos escritos, (iii) verificar em que medida a língua falada influencia na organização do texto escrito, quando se exige o uso da norma padrão da língua; e (iv) observar a influência da prosódia da língua falada sobre a organização textual escrita em casos específicos de uso da vírgula. Esses passos pretendem confirmar ou refutar as teses básicas de que o texto argumentativo deve ser trabalhado com os alunos desde o sexto ano e que a oralidade influencia na estruturação do texto escrito, sobretudo na pontuação. Em razão dos objetivos delimitados, esta pesquisa se insere na linha de pesquisa do Programa de PósGraduação em Linguística da Universidade de Brasília (PPPGL - UnB) e está relacionada à Teoria e Análise Gramatical, já que um dos processos para alcançar os objetivos traçados é analisar a estrutura gramatical da língua escrita em uso pelos alunos do sexto ano.

Para se alcançar os objetivos acima expostos, é necessário obter algumas respostas para questionamentos relacionados à produção de textos escritos desse segmento. Quais são as principais interferências da oralidade na escrita dos alunos de sexto ano? Que problemas estruturais são mais recorrentes nas produções de textos argumentativos dessa faixa etária? Em que medida a tipologia argumentativa influencia na qualidade das produções de texto em alunos de sexto ano? A artificialidade do uso da língua escrita proposta pela escola nas produções de redações influencia na qualidade do ensino? Como os alunos percebem as estruturas formadoras do texto argumentativo (frases e parágrafos)? Como o docente pode intervir positivamente e produtivamente nas produções de textos escritos?

O primeiro passo em direção às respostas dos questionamentos feitos acima foi decidir que seria feita uma análise dos erros dos estudantes em suas produções de texto escrito. Com isso, seria possível mapear as estruturas mais complexas para os alunos do sexto ano, verificar seu uso, construir hipóteses para a origem da dificuldade e pensar em soluções para a questão. Nessa etapa do processo, confirmou-se a influência da oralidade sobre a escrita, nos níveis do segmento e do suprassegmento, e isso ganhou destaque nas análises aqui propostas.

As análises aqui realizadas têm como base teórica a Linguística Funcional Centrada no Uso $(U B L)$, por se acreditar que a função primeira da linguagem é a comunicação e que a gramática emerge do uso, e não o contrário. Dentre os estudiosos da $U B L$, esta pesquisa toma como base os estudos de Bybee, Tompson, Tomasello e, no Brasil, Martelotta, Bispo e Cunha. 
Essa decisão teórica influenciou diretamente no desenho da pesquisa, especialmente na busca de justificativas cognitivas para as estruturas da língua portuguesa usadas de forma diversa da proposta pela norma padrão. Além disso, a necessidade de se verificar e analisar a língua em uso fez com que a pesquisadora comparasse a norma padrão, via gramáticas tradicionais, com a realidade da língua no processo comunicativo dos alunos em foco, ainda que essa comunicação se processasse entre aluno e professor, em situações simuladas de interação e por intermédio de produções de textos escritos, ou seja, as comunicações analisadas tinham em sua natureza o caráter didático-pedagógico, não eram espontâneas, como seriam as interações processadas via texto oral, entre professor e aluno, durante uma aula, por exemplo.

A opção teórica pela $U B L$ também definiu a necessidade de se tentar verificar o ponto de vista dos alunos de sexto ano em relação a estruturas do texto escrito, paragrafação e pontuação. Assim, optou-se por aplicar um questionário aos alunos investigados para relacionar as respostas dadas ao uso que eles fazem de tais estruturas básicas para a elaboração de qualquer texto escrito. Esse foi um recurso primordial para a compreensão e análise dos dados das produções de textos.

Os dados produzidos pelas redações dos alunos foram analisados com base em cinco macrocritérios, a saber: Escrita Formal, Tipologia Textual, Paragrafação, Coesão e Pontuação. Esses foram definidos e subdivididos em microcritérios com base em duas grades de correção de redações e questões discursivas utilizadas em exames de larga escala: ENEM e Processos Seletivos para ingresso na Universidade de Brasília. Essas grades de correção foram adaptadas aos dados, para que atendessem às necessidades do público-alvo, já que elas são aplicadas em correção de redação para concluintes do Ensino Médio e os alunos investigados estavam acabando de iniciar o Ensino Fundamental II.

Dentre os cinco macrocritérios de análise delimitados, três foram analisados em comparação com o texto oral. São eles: Escrita Formal, Paragrafação e Pontuação. Nos três, visava-se verificar como a fala interferia na escrita, sobretudo em relação aos dois últimos, pois tinha-se como premissa, na pesquisa, que a entonação poderia levar o aluno, no sexto ano, ao erro de estrutura no texto escrito. Dessa forma, para a análise da Pontuação, cada microcritério foi comparado ao texto oral. Para tanto, um programa de rádio foi analisado acusticamente e a comparação feita indicou que a entonação pode conduzir o aluno ao erro no texto escrito, mas também ao acerto. Essa análise foi fundamental para compreender o uso da pontuação no texto escrito, pois justificou alguns equívocos estruturais, na medida em que foi possível identificar a motivação para o uso de determinada estrutura. 
A partir do mapeamento dos principais problemas estruturais nas produções de texto dos alunos de sexto ano e com base na $U B L$, foram apresentadas algumas propostas de intervenção didática para conduzir os alunos à possível melhora de sua habilidade escritora. Acredita-se que é importante oferecer aos alunos condições de se usar a língua que está sendo aprendida na escola, a escrita padrão, para que o uso intensificado das novas estruturas adquiridas possa se tornar natural para os alunos, de forma a escrita padrão lhe seja tão familiar que influencie positivamente a língua usada na modalidade oral, e que passe a estar presente nas interações cotidianas e corriqueiras do aluno. É importante ter em conta que essa pesquisa apresenta características próprias da Pesquisa-Ação, já que toda a investigação foi feita com base em análises de aulas, tendo a sala de aula como locus de pesquisa. Nesse processo, os resultados das investigações feitas em sala de aula geram intervenções didáticas, e os resultados dessas definem os próximos passos da pesquisa.

Por ter seu foco na sala de aula e no ensino de produção de texto escrito em Língua Portuguesa no sexto ano, esta pesquisa tem como objetivo adicional ser mais uma ferramenta para a capacitação de docentes que irão atuar como agentes na tentativa de mudar o quadro atual da educação no Brasil, além de atender a interessados em descrição linguística, com um olhar funcionalista sobre a linguagem. Aqui se revisitam algumas discussões já antigas na área de ensino de Língua Portuguesa, que pouco têm influenciado a prática pedagógica, além de apresentar um novo olhar sobre temas antigos, como o ensino da organização textual e o enfoque, desde essa fase escolar, do texto argumentativo. Isso se justifica pela importância que o ato de argumentar tem na vida dos indivíduos, além de a argumentação já fazer parte da realidade dos alunos no sexto ano. É importante, ainda, frisar que análises desta pesquisa foram feitas com base em produções de alunos de apenas uma escola, mas acredita-se que esse é um recorte significativo e representativo da realidade do ensino de Língua Portuguesa.

Este trabalho está organizado em cinco capítulos, dois relativos à revisão da teoria e de documentos acerca do ensino de Língua Portuguesa, e dois centrados na análise dos dados e em propostas didáticas que visam ao incremento do ensino de redação, com base nos resultados apresentados. Assim, o primeiro capítulo faz uma síntese dos pressupostos teóricos e tem como centro o olhar funcionalista sobre a linguagem, mais especificamente as premissas do Funcionalismo Centrado no Uso. Como o objeto de estudos desta tese é composto, ainda, pelas produções de texto escrito de alunos, apresenta-se, também, nesse capítulo, teorias relacionadas ao estudo do texto, além de questões relativas à fonologia e à prosódia. 
O capítulo dois aborda algumas teorias acerca do ensino de Língua Portuguesa, além de apresentar algumas propostas da Base Nacional Curricular Comum e fazer uma revisita aos PCN, sobre pontos importantes para o ensino de Língua Portuguesa. Além disso, há também a apresentação das matrizes de correção de redação e questões discursivas utilizadas no ENEM e pelo CEBRASPE ${ }^{4}$ - para a correção de concursos de avaliação e seleção, com destaque para o Programa de Avaliação Seriada (PAS) da Universidade de Brasília - que embasaram os critérios de análise dos dados adotados aqui, e também uma revisão sobre a abordagem da pontuação em gramáticas tradicionais, para que, na análise dos dados, as definições constantes nesses materiais possam ser comparadas ao uso desse sinal gráfico pelos alunos.

O capítulo três enfoca o percurso trilhado nesta pesquisa, com a apresentação dos procedimentos metodológicos aplicados. É nele que se expõem a formulação e a organização do corpus, os instrumentos utilizados para as análises e as tomadas de decisão em relação ao desenho desta tese. Como ponto fundamental do capítulo, tem-se a exposição de informações relativas à escola em que a pesquisa foi realizada e aos alunos que deram vida a este trabalho.

O capítulo quatro é o centro da tese, pois nele estão a descrição e a análise dos dados, acompanhadas das discussões que esses suscitaram. Nele é feita a junção do embasamento teórico com a língua escrita em uso pelos alunos do sexto ano, além de apresentar o ponto de vista deles em relação a teorias do texto e sua organização, por meio do questionário aplicado. Esses dados, confrontados com as produções de texto, trazem luz a questões que podem auxiliar o docente na tentativa de possibilitar ao aluno um ensino mais significativo e eficaz. É nesse capítulo que o mapeamento das dificuldades e desvios da norma-padrão escrita é apresentado. Esse mapeamento é fundamental para que gestores e docentes possam buscar melhorias para a qualidade do ensino de Língua Portuguesa, uma vez que apresenta as principais dificuldades dos alunos em relação à língua padrão escrita, que acompanharam os estudantes durante o Ensino Fundamental I e influenciá-los-ão ao longo de toda trajetória escolar.

O capítulo cinco é uma reflexão sobre como a pesquisa realizada pode se refletir em sala de aula, afinal grande parte dos pesquisadores que têm a sala de aula como ambiente de investigação deseja que suas pesquisas repercutam na prática escolar. Assim, algumas propostas de intervenção foram pensadas e aplicadas, ao longo do processo de investigação, com o grupo focal de pesquisa e essas terão seus resultados comentados. Outras propostas didáticas não tiverem a possibilidade de ser implementadas, mas são justificadas e discutidas ao longo de sua

\footnotetext{
${ }^{4}$ Centro Brasileiro de Pesquisa em Avaliação e Seleção e de Promoção de Eventos. Material disponível em http://www.cespe.unb.br/pas/Prova\%20de\%20Reda\%C3\%A7\%C3\%A3o\%20do\%20PAS\%20-\%20V11.pdf
} 
apresentação. É importante destacar que as propostas discutidas foram guiadas pelos resultados indicados na análise de dados, assim, têm fundamentação no uso da língua.

Com todo o exposto, esta tese convidará o leitor a uma discussão sobre o ensino de produção de texto no sexto ano do Ensino Fundamental II, com um recorte específico, já que os dados foram coletados em uma escola particular bilíngue de Brasília. Ao longo da leitura, poderão verificar que a questão do bilinguismo pouco influencia os alunos, já que a transposição de conteúdos e estruturas de uma língua para a outra fica restrita a questões ortográficas, conforme é possível verificar no capítulo quatro. Além disso, será possível também verificar que o aluno domina a norma padrão da linguagem escrita em alguma medida, e seria interessante que à escola coubesse melhorar a estrutura trazida por ele para a sala de aula. Outro enfoque é no que diz respeito à relação entre entonação e pontuação, já que as análises põem em cheque algumas afirmações clássicas sobre o assunto, como a relação entre uso da vírgula e a pausa. Sobre o uso da vírgula, no capítulo dois é possível verificar a abordagem desse tópico por cinco gramáticos distintos, o que resulta em um rico material de consulta a respeito desse tema complexo. Além disso, algumas propostas em relação ao ensino da produção de texto no sexto ano são apresentadas, no capítulo cinco, e seria interessante se essas ecoassem, minimamente, na sala de aula, na tentativa de se encontrar um caminho para reverter a realidade brasileira em relação à competência escritora dos alunos em formação básica. 


\title{
Capítulo 1 - A base teórica: questões sobre linguística
}

\begin{abstract}
A dysfunctional paradigma in Science is a conceptual trap, constraining the mind of the practitioner just as viciously as steel bars would do to his body ${ }^{5}$. Talmy Givón, 1979: 02.
\end{abstract}

Esta pesquisa tem como pedra fundamental a crença de que a linguagem é meio de interação social, e de que só através dela é que todo e qualquer tipo de expressão acontece. Dessa forma, a comunicação passa a ser o objeto de análise, pois se deseja investigar a língua em uso e os processos cognitivos que permeiam o ato comunicativo, em contraponto a estudos focados em sentenças estanques ou palavras descontextualizadas.

A situação comunicativa aqui analisada é a existente entre o aluno do sexto ano do Ensino Fundamental II e seu professor, na atividade didática de produzir textos escritos, com defesa de ponto de vista. Analisando-se os textos escritos dos alunos, é possível chegar a uma regularidade estrutural da gramática em uso e da organização textual mais produtiva para esse grupo. Por sua interface com o ensino de Língua Portuguesa sob o viés escolar, este estudo considerará, também e de maneira secundária, a visão da linguagem centrada em estruturas linguísticas, presentes nas gramáticas tradicionais, em que observa a presença de metalinguagem e regras de uso da modalidade padrão da língua, independentemente de serem utilizadas por seus falantes nativos.

Então, esta pesquisa tem o centro de sua base epistemológica voltado para algumas das teorias linguísticas que têm como premissa básica uma visão de cunho Funcionalista e que consideram, também, os estudos Cognitivos sobre a linguagem. Assim, este estudo encontrou sustentação teórica e metodológica na Usage-Based Linguistic ${ }^{6}(U B L)$. Essa vertente reúne conceitos do Funcionalismo e da linguística Cognitiva, e tem, entre seus pesquisadores centrais, nomes como Bybee, Tompson, Tomasello e, no Brasil, Martelotta, Bispo e Cunha.

Serão apresentados, nas próximas páginas, conceitos fundadores das correntes linguísticas aqui consideradas, assim como o enfoque teórico com os quais serão observados os dados. O capítulo se inicia com uma breve explanação sobre o Funcionalismo e sobre a Linguística Cognitiva, isso para proporcionar uma visão geral das bases teóricas que, juntas, compõem a Usage-Based Linguistic (em geral, neste trabalho, será usada a sigla $U B L$ para se

\footnotetext{
5 "Um paradigma disfuncional na ciência é uma armadilha conceptual, restringindo a mente do praticante tão malignamente quanto barras de aço o fariam a seu corpo”. Givón, 2012: 14
}

${ }^{6}$ Linguística Baseada no Uso. 
referir a esse termo), perspectiva teórica que suporta todo o estudo aqui realizado. Em seguida, são apresentados os fundamentos da $U B L$ e seu olhar sobre os estudos de fonologia, que constitui a Fonologia Baseada no Uso. Após situar o embasamento teórico adotado, serão abordadas questões sobre as teorias que têm o texto como objeto de análise, com ênfase na organização dos parágrafos e na coesão textual. Por fim, este capítulo se deterá nos pressupostos teóricos relativos à Prosódia, tendo em vista a análise acústica, que será apresentada no Capítulo 4. Dessa forma, será possível ter um panorama das teorias linguísticas que sustentam o trabalho apresentado e que nortearam os resultados que serão apresentados e discutidos mais adiante.

\subsection{Sobre o Funcionalismo}

O ser humano é a única espécie, até agora, apontada como capaz de aprender e usar conjuntos de regras linguísticas relativos à linguagem e, por meio deles, se comunicar com outros seres da mesma espécie, além de poder produzir registros dessa comunicação. Sobre isso, alguns estudiosos de cunho gerativista defendem a existência de uma capacidade inata, própria aos homo sapiens, de desenvolver uma Gramática Universal, com base em inputs relacionados à comunicação. Essa característica é o que levaria uma criança a aprender as regras de uma determinada língua sem ter passado por um ensino formal do idioma. Nessa visão, a gramática é composta de um rígido e categórico sistema de regras e estruturas, as quais existem independentemente de seu uso e função. Em estudos que enfocam essa perspectiva teórica, a língua é analisada por si só, de acordo com um padrão estrutural que independe de seu usuário. O grande estudioso e representante dessa linha de análise da linguagem é Noam Chomsky.

Nesta pesquisa, compreende-se a linguagem como ferramenta de expressão de sentimentos e pensamentos, e, portanto, como meio de comunicação e de interação entre humanos. Em razão desse entendimento, o construto teórico que sustenta este trabalho tem como base correntes teóricas de cunho Funcionalista. Nessa linha de análise, toda criança nasce com a capacidade cognitiva de desenvolver a linguagem, de acordo com os estímulos que recebe, sendo essa, então, uma competência desenvolvida por exposição e uso de um determinado sistema de regras, e não uma capacidade inata do ser. Além disso, Bybee (1998) destaca como ponto importante dessa vertente teórica a compreensão de que as línguas vivas podem criar, e criam, novas gramáticas, uma vez que são influenciadas pelo uso e por seu valor 
discursivo. Esse ponto diverge da rigidez formal em relação à língua, defendida pelos estudiosos gerativistas.

Croft $\left(2013^{7}\right)$ ensina que, no Funcionalismo, a ênfase da análise é no significado que a estrutura tem dentro do discurso, e não na estrutura por si só, como fazem os modelos de análise formalistas. Isso faz com que a observação da linguagem em uso em situações reais de comunicação seja imprescindível para os estudiosos dessa linha, já que uma mesma estrutura sintática pode desempenhar diferentes funções, de acordo com o uso que o falante faz dela. Consequentemente, é possível encontrar regularidades entre idiomas, como o é a preferência da sufixação (em comparação com os prefixos) para a formação de palavras. Nessa valorização do discurso para a análise Funcionalista, é importante considerar os ensinamentos de Givón (1979), que elaborou um esquema para explicar os processos diacrônicos de regularização do uso da língua, no qual ficou claro que tudo começa no discurso e morre na morfofonologia. Além disso, esse estudioso postula as seguintes premissas do Funcionalismo, em sua revisão da teoria, publicada na década de 90 (1995: 09):

- languages is a social-cultural activity

- structure serves cognitive or comunicative function

- $\quad$ structure is non-arbitrary, motivated, iconic

- change and variation are ever-present

- meaning is context-dependent and non-atomic

- $\quad$ categories are less-than-discrete

- $\quad$ structure is maleable, not rigid

- grammars are emergent

- $\quad$ rules of grammar allow some leakage. ${ }^{8}$

Os estudos funcionalistas também lançam seu olhar sobre a oposição entre a oralidade e a escrita, que passa a ser foco de pesquisas. Uma justificativa para isso é o já mencionado enfoque no discurso, no qual a comunicação real passa a ser considerada como objeto de investigação e pode acontecer tanto com o uso da oralidade quanto com o da escrita. Nesse

\footnotetext{
${ }^{7}$ Paper publicado na página pessoal de William Croft, disponibilizada pela Universidade do Novo México. Na página, há a informação de que o arquivo foi atualizado pela última vez em 24 de abril de 2013. Disponível em http://www.unm.edu/ wcroft/Papers/Functionalism-IESBS2ed.pdf . Acesso em 30 de março de 2015.

8 Tradução nossa: a linguagem é uma atividade sociocultural / a estrutura serve a uma função cognitiva ou comunicativa / a estrutura é não-arbitrária, motivada e icônica / mudança e variação estão sempre presentes / o significado é não atômico e dependente do contexto de comunicação / as categorias são menos que discretas / a estrutura é maleável, não é rígida / a gramática é emergente / as regras da gramática permitem alguns desvios.
} 
âmbito, pesquisar a relação entre escrita e oralidade é importante para identificar as regularidades estruturais que permeiam essas modalidades da língua. Esse ponto é crucial para a investigação que ora se apresenta, já que se toma como premissa a influência da oralidade sobre a produção do parágrafo argumentativo escrito.

É importante frisar, para as análises que serão apresentadas, que não é possível explicar os fatos gramaticais sem avaliar o contexto de uso de uma estrutura. É o que defende Decat (2004) em seu estudo sobre as cláusulas adverbiais hipotáticas, no qual afirma que a intencionalidade do discurso guia as escolhas estruturais do falante, fazendo com que uma análise descontextualizada de tal aspecto não proporcione uma visão real do seu uso.

Um dos termos basilares para os estudos com base no Funcionalismo é 'função'. A definição encontrada para essa palavra no minidicionário Aurélio (2010: 366) é “1- ação própria ou natural dum órgão, aparelho ou máquina; 2- cargo, serviço, ofício; 3- prática ou exercício de função; 4- utilidade, serventia; e 5- posição, papel; atribuição”. Observa-se que as acepções estão todas relacionadas a desempenho, indiciando a relação que há entre ‘função' e a situação, ou o contexto, em que determinado elemento está inserido. No âmbito dos estudos linguísticos, Halliday entende a função como "o papel que a linguagem desempenha na vida dos indivíduos, servindo aos muitos e variados tipos universais de demanda". Neves (2006) afirma que o termo em foco é entendido "não apenas como entidade sintática, mas como a união do estrutural (sistêmico) com o funcional”. Já Poggio (2002: 32) apresenta que "na tradição gramatical, entende-se por função o papel de uma palavra numa proposição, tudo o que se junta ao seu sentido em determinado contexto. Assim, uma palavra terá uma natureza permanente e uma função que vai depender do seu lugar no discurso".

Como anteriormente mencionado, no ato comunicativo, ou seja, no discurso, a mesma estrutura gramatical pode assumir distintas funções, e, consequentemente, diversas possibilidades semânticas e pragmáticas, pois a linguagem é funcional e propicia essa possibilidade. Isso corrobora a importância de não se investigar as estruturas linguísticas e gramaticais sem seu contexto de produção. Nesse viés, Neves (2006: 18) ensina que

estruturas linguísticas são, pois, configurações de funções, e as diferentes funções são os diferentes modos do significado do enunciado, que conduzem à eficiência da comunicação entre os usuários de uma língua. Nessa concepção, funcional é a comunicação, e funcional é a própria organização interna da linguagem.

Os estudos de cunho formalista não conseguem, por vezes, explicar ou prever fatos linguísticos que aparecem no uso da língua, pois estão considerando apenas o nível estrutural. 
Dessa forma, percebe-se que observar as motivações contextuais e situacionais que levam o falante a utilizar determinada estrutura pode justificar algumas das formações estruturais de que o olhar formal sobre a língua não dá conta, como é o caso da estrutura verbo-sujeito proposto por Naro e Votre (1989:179). Esses estudiosos são precursores do Funcionalismo no Brasil. Segundo eles, "a análise formal propõe soluções categóricas, quando os dados, de fato, mostram um continuum de usos". Naro e Votre propõem ainda que "os fatos reais, bem como a explicação consequente, estão no domínio da performance" (1989: 180).

Outro conceito Funcionalista que vale ser abordado nesta revisão de pressupostos teóricos, dada a sua relevância, é o de gramaticalização. Esse é um processo que comprova o caráter mutável de uma língua viva, como mencionado anteriormente, pois preconiza que uma determinada palavra, por exemplo, pode ter sua classe morfológica alterada, de acordo com o uso que os falantes fazem dela. Na língua portuguesa, pode-se observar tais características, por exemplo, em advérbios terminados em "-mente" que, segundo estudos de Rodrigues (2004), assumem papel de conectivos, e, nesse caso, um elemento, antes, com alto grau de mobilidade - o advérbio -, passa a ter uma posição mais fixa - o conectivo.

Detendo-se um pouco mais ao conceito em análise, Lehman (Lehman, 2002 [1982] e 1985) e Traugott (2010) ensinam que o termo foi usado pela primeira vez em 1912, por Antoine Meillet, que reviu e aprimorou a teoria de Gabelentz sobre aglutinação ${ }^{9}$, ao publicar o artigo "L'évolution des formes grammaticales". Além disso, eles afirmam que o processo de gramaticalização está relacionado à mudança gramatical, essa atuando sobre a estrutura e sobre o significado do termo em evolução. Segundo os estudiosos, a gramaticalização é um processo que não apenas transforma um item lexical em gramatical, mas que, de acordo com Kurylowicz (autor citado por Lehman e Trougott), "shift an item "from a less grammatical to a more grammatical status ${ }^{10}, "$

Hopper \& Trougott (2003) postulam que o termo tem dois significados, um relacionado às investigações sobre os fenômenos de mudança gramatical e o outro, aos próprios fenômenos. O processo de gramaticalização ocorre, segundo Bybee (1998), quando um termo, no discurso, é usado de forma diversa de sua função gramatical original. Com a recorrência dessa adaptação discursiva, o termo assume nova função, e, geralmente, um item lexical, mais maleável - como no caso do advérbio, já mencionado -, assume uma nova função gramatical, ganhando maior

\footnotetext{
${ }^{9}$ Para maiores informações sobre o conceito de aglutinação e sobre o percurso histórico da gramaticalização ver Lehman, 2002 [1982].

${ }^{10}$ Tradução nossa: altera o status de um item menos lexical para mais gramatical.
} 
rigidez estrutural, como o conectivo (exemplo apresentado anteriormente, em que o advérbio sofre o processo de gramaticalização e passa a atuar, no discurso, como conectivo). Há também a possibilidade de alteração de significado que, assim como a alteração sintática do termo, acontece de forma espontânea, em qualquer língua natural.

Lehman (1985: 303) ensina que há duas perspectivas sobre gramaticalização: a sincrônica e a diacrônica. Sobre isso, o estudioso defende que

I will use the concept both on the synchronic and the diachronic axes. Under the diachronic aspect, grammaticalization is a process which turns lexemes into grammatical formatives and makes grammatical formatives still more grammatical (cf. Kuryłowicz 1965:52). From the synchronic point of view, grammaticalization provides a principle according to which subcategories of a given grammatical category may be ordered ${ }^{11}$.

Givón (1995) traz a noção de que a gramática se adapta às transformações sociais e culturais da sociedade, e que o contexto de comunicação fica cada vez mais específico. Por isso, a língua precisa se adaptar e o faz por meio da gramaticalização. Retornando aos estudos de Lehman, em sua revisão do trabalho de 1982 - realizada em 2002 - o estudioso indica que há quatro estágios essenciais no processo de gramaticalização: “the four stages are essentially the morphological types of the linguistic typology of the time: stages I and/or II = isolating, III = agglutinative, $I V=$ flexional $^{12}$ " (Lehman, 2002 [1982]:02). É importante considerar que os conceitos funcionalistas estudados até aqui estão relacionados à análise da linguagem em seu uso. Esse, por sua vez, está atrelado às situações comunicativas em um nível externo de análise. Ou seja, no Funcionalismo não são avaliadas as motivações mentais relacionadas ao uso da linguagem, pois isso é feito na Linguística Cognitiva, que será abordada a seguir.

No Brasil, os estudos sobre gramaticalização atraíram o interesse dos estudiosos da corrente Funcionalista, e teve como importante nome o linguista Mário Martelotta, primeiro doutorando a defender uma tese sobre tal conceito, em 1994. Ele integrava o grupo de pesquisa do professor Sebastião Votre e, durante sua carreira, orientou diversos trabalhos sobre gramaticalização, processo que continua atraindo o interesse de pesquisadores. A gramaticalização evidencia a necessidade de se tomar a língua em uso como base de análise, o que também foi sendo feito no trabalho apresentado. Apesar de os dados não terem sinalizado

1111 Tradução nossa: usarei o conceito tanto no eixo sincrônico, como no diacrônico. Sob o aspecto diacrônico, gramaticalização é um processo que transforma lexemas em formas gramaticais e faz termos gramaticais ficarem ainda mais gramaticais (cf. Kuryłowicz, 1965: 52). Do ponto de vista sincrônico, a gramaticalização fornece um princípio, segundo o qual as subcategorias de uma determinada categoria gramatical podem ser ordenadas.

12 Tradução nossa: os quatro estágios são essencialmente os tipos morfológicos da tipologia linguística da época: as fases I e / ou II = isolamento, III = aglutinação, IV = flexão. 
esse processo no corpus, não há como tratar de Funcionalismo sem mencionar a gramaticalização, por isso o tratamento dispensado a ela na composição da base teórica desta pesquisa.

\subsection{Linguística Cognitiva}

No que diz respeito à compreensão da linguagem não é possível deixar de considerar os processos cognitivos que a envolvem, afinal não há formação de pensamento sem linguagem, e não há linguagem sem a ativação de processos mentais. Tendo-se como base os processos mentais próprios à linguagem, emergem, na década de 70, nos Estados Unidos (mais especificamente na Universidade de Berkeley), investigações voltadas à relação entre linguagem e cognição, que deram início à Linguística Cognitiva. Essa analisa questões relacionadas ao pensamento para justificar a estrutura das línguas, com ênfase em seu aspecto semântico. Sobre isso, Salomão (em entrevista a Abraçado, 2010) enfatiza que essa corrente teórica tem um caráter "semantocêntrico" e não "sintatocêntrico", como o Gerativismo, por exemplo.

A Linguística Cognitiva é uma corrente de estudos da linguagem que emerge da Semântica Gerativa, sucedendo-a, e traz consigo, ainda, características próprias dos estudos Estruturalistas e Funcionalistas. Sobre essa característica, Martelotta (2006) afirma que há duas visões da cognição: uma racionalista e outra experiencialista. A primeira visão tem como base a visão biológica da linguagem humana, centrada na lógica, sem considerar os aspectos sociais, no qual a linguagem é um sistema formal interpretado. Seu maior representante é Chomsky. Já a visão experiencialista da cognição, que leva em conta os fatores sociais, para o qual a linguagem é "um dispositivo para a criação do conhecimento" (idem). Alguns nomes importantes para essa visão da cognição são Lakoff, Langacker, Fauconnier e Tomasello, nos Estados Unidos, e Salomão, no Brasil.

Além de sua diversidade conceitual, observa-se também o caráter interdisciplinar da Linguística Cognitiva, uma vez que essa mantém relação com a Psicologia Cognitiva, a Neurociência e a Inteligência Artificial, por exemplo, como afirma Abraçado (2010: 23). A justificativa para isso, de acordo com Salomão (idem), é seu enfoque semântico, já que investiga as "relações da linguagem com os outros sistemas cognitivos, com as outras semioses". 
Essa corrente teórica refuta o argumento dos estudiosos ligados ao Gerativismo de que a mente humana é organizada em módulos, e que um deles é o responsável pela linguagem (a questão gerativa da modularidade da mente). Para a Linguística Cognitiva, segundo Martelotta (2009:179), a linguagem não é independente das outras faculdades mentais e, portanto, não é um componente autônomo.

Nessa perspectiva teórica, os usuários das línguas naturais são vistos sob um novo ângulo, pois o falante não é mais um reprodutor de regras gramaticais já estabelecidas, ele passa a agir sobre a língua, construindo significados ao longo da comunicação. Outro ponto importante é que os aspectos pragmáticos são fundamentais, uma vez que o contexto de comunicação e a situação interacional passam a ser determinantes para a construção do sentido.

A Linguística Cognitiva acredita que a sintaxe é organizada a partir da semântica, com isso, observa-se a refutação de mais um princípio do Gerativismo: a autonomia da sintaxe. Além disso, o uso da língua também pode configurar a realização de ações. Essa ideia é a base da teoria dos Atos de Fala, proposta por Austin e revista por Searle, o que contribui para salientar a relevância da experiência e da situação comunicativa para as análises das estruturas linguísticas.

Nessa perspectiva, as análises alinhadas aos pressupostos cognitivos têm como objeto de análise dados reais de comunicação, ponto convergente aos estudos de base Funcionalista, em busca de características estruturais que confirmem, ou não, as hipóteses do pesquisador. Esse ponto é fundamental para o estudo que está sendo apresentado, uma vez que o corpus de análise se baseia em produções de textos de alunos, ou seja, em dados reais produzidos em uma situação de interação didática específica, própria do contexto escolar.

Lakoff (1994) propõe que a análise cognitiva da linguagem vá além da interpretação, buscando representar, de forma detalhada, as regularidades estruturais que subjazem as inferências inconscientes acionadas para a compreensão de um texto. O estudioso também afirma que a Semântica Cognitiva trouxe novas ferramentas para as análises conceituais da linguagem, para além do âmbito da Filosofia. Essas seriam, entre outras: a noção de protótipos, os frames semânticos e as metáforas.

Retomando a entrevista de Salomão a Abraçado (2010: 18), tem-se como base da Linguística Cognitiva os postulados a seguir. 
(i) A centralidade dos estudos da significação praticados numa vertente inferencialista (Brandon), que subjaz à semântica de frames e a todos os tratamentos corporificados das relações figurativas estruturantes do léxico e da sintaxe; (ii) hipótese da continuidade entre linguagem e cognição humana, hipótese não-modularista, que vem recebendo recentemente um corte evolucionário cada vez mais definido; (iii) idiomatismo constitutivo das formas linguísticas, formulação fundadora de todas as abordagens construcionistas, mas enunciada com mais veemência pela Gramática Radical das Construções, subscrita por Croft: dentro dessa linhagem do pensamento, um ponto a ressaltar é a gradiência que caracteriza a distinção das formas do léxico e da sintaxe; e (iv) importância do uso na gramatogênese, tanto em termos ontogenéticos, ilustrados pelos estudos de Tomasello, como em termos históricos, exemplificados por estudos como os de Kemmer, os quais acabam por reiterar o caráter idiomático das gramáticas das línguas particulares. Essa dimensão lança pontes importantes em direção à linguística funcionalista, especialmente aquela que se interessa pelos estudos da gramaticalização (haja vista o diálogo TraugottMichaelis em número recente, de 2007, do periódico Cognitive Linguistics).

Alguns conceitos são importantes para as análises com base na Linguística Cognitiva, pois conduzem os estudos nessa área, e são importantes se mencionar em uma síntese das ideias relativas a essa linha teórica. São eles:
a) domínios conceptuais - modelos cognitivos idealizados (mci), molduras comunicativas e esquemas imagéticos;
b) espaços mentais;
c) princípio da projeção; e
d) mesclagem (blending).

É importante frisar que esta pesquisa toma a Linguística Cognitiva, assim como o Funcionalismo, como pressupostos básicos para a principal corrente teórica aqui utilizada, sobretudo na análise de dados. Assim, conceitos específicos da área, como os apresentados no parágrafo anterior, não serão utilizados aqui, por isso a proposição de uma visão geral dessas teorias na composição do presente quadro teórico. 


\subsection{Usage-Based Linguistic (UBL) ${ }^{13}$}

Os conceitos básicos das Linguísticas Funcional e Cognitiva foram abordados até aqui para formar o percurso teórico que conduz à principal teoria que subsidia esta pesquisa: a Usage-Based Linguistic (UBL), ou Linguística Funcional Centrada no Uso (LFCU), ou Linguística Cognitivo-Funcional. É possível, então, entender que se trata de uma extensão das correntes basilares dessa forma de se olhar para a linguagem. Nessa perspectiva, todos os fenômenos linguísticos emergem do uso, ou seja, do processo comunicativo.

Os pressupostos primordiais da Usage-Based Linguistic têm como base a noção de que a linguagem emerge da relação que há entre a cognição e o uso da língua. Tomasello (2008: 69) ensina que a comunicação linguística se resume a dois aforismos: "meaning is use ${ }^{14 "} \mathrm{e}$ "structure emerges from use 15 ". Para o estudioso, a primeira afirmação tem relação com os caráteres funcional e semântico da linguagem, enquanto a segunda estaria alinhada às bases do estruturalismo, contudo, sem deixar de se ter em mente que os teóricos dessa linha anseiam refutar a ideia de que a estrutura linguística é desprovida de caráter semântico.

Um dos principais nomes que embasam esta pesquisa, no que diz respeito à $U B L$, é o da professora da Universidade do Novo México Joan Bybee. Citando Langacker, Bybee (2013: 49) afirma que a premissa básica dessa corrente teórica é que a experiência com a linguagem cria e causa impacto nas representações cognitivas da linguagem. Ela também ensina em seu texto de 2010, capítulo de publicação organizada por Clay Beckner, que essa perspectiva, como o nome já indica, "incorporates the basic insight that usage has an effect on linguistic structure $^{16 "}$.

A $U B L$ contempla uma visão da linguagem e uma linha de análise que integram, à estrutura da língua, aspectos pragmáticos e discursivos. Além disso, é possível realizar uma análise para além da morfossintaxe englobando, também, afora os mencionados no início deste parágrafo, aspectos cognitivos, semânticos e fonológicos. Tem-se, portanto, uma linha de análise diversa, que possibilita um profundo estudo dos fenômenos linguísticos, já que se

\footnotetext{
${ }^{13}$ Neste trabalho, optou-se pela utilização do termo original, em inglês, para fazer referência à principal corrente teórica aqui utilizada: Usage-Based Linguistic.

14 Tradução nossa: significado é uso.

15 Tradução nossa: a estrutura emerge do uso.

${ }^{16}$ Tradução nossa: incorpora a visão básica de que o uso tem influência sobre a estrutura linguística.
} 
propõe a descrever e a explicar a gramática, como afirmam Cunha; Bispo; Silva (2013). Esses são o viés teórico e o objetivo desta pesquisa, no que diz respeito à organização textual de alunos do sexto ano.

Em favor da adoção da $U B L$ como abordagem teórica, Bybee, em entrevista publicada na Revista LinguíStica - em junho de 2012 -, advoga que esse é um modelo mais plausível em comparação àqueles que entendem estrutura e uso como elementos dissociados. Além disso, a $U B L$ reconhece a plasticidade do cérebro e como ele responde a experiências que relacionem a linguagem a outros processos cognitivos, como a memória ${ }^{17}$.

Para os estudos dessa abordagem, é fundamental analisar a linguagem em uso, considerando-se os papéis do contexto comunicativo e dos participantes da interação. Dessa forma, nota-se que não é possível investigar línguas naturais com dados construídos ou com sentenças isoladas ou descontextualizadas, como preconizam as correntes teóricas de cunho puramente formalista. Na $U B L$, é necessário adotar uma metodologia de coleta e análise de dados em que esses sejam obtidos em situações reais de uso da língua, e que possam ser analisados qualitativa e quantitativamente. Esse é mais um ponto central para a pesquisa ora apresentada, o que, também, justifica a opção teórica realizada. O caráter metodológico deste estudo e sua relação com a $U B L$ serão abordados no Capítulo 3.

Ainda segundo as bases dessa teoria, Bybee (2010: 01) ensina que o fenômeno da estrutura presente na gramática de línguas naturais pode ser derivado de domínios gerais de processos cognitivos, operados em múltiplas instâncias da língua em uso. Além disso, com base no conceito de que a estrutura emerge do uso, nota-se que o processo da criação da linguagem é dinâmico, uma vez que a sociedade e a cultura estão em constante renovação.

Ao se pensar em mudança e variação linguísticas, a $U B L$, assim como o Funcionalismo, analisa esses processos com base no conceito de gramaticalização. Por isso é importante analisar a língua em uma perspectiva pancrônica, ou seja, levando em conta sincronia e diacronia. Sobre mudança e variação, Bybee (2010) afirma que o uso repetitivo de determinado processo na língua pode causar impactos na representação cognitiva da linguagem.

Pode-se relacionar esse conceito com a frequência de ocorrência do termo "coisa" nos dados que constituem o corpus desta pesquisa. O termo vindo do latim é classificado morfologicamente como substantivo que pode ser núcleo de termos da oração e designar um

\footnotetext{
17 Tradução nossa. Texto original: "A general argument would be that usage-based models are cognitively more plausible than models that try to divorce structure from usage. They recognize the plasticity of the brain and how it responds to experience and treat language in a way that is congruent with what is known about other cognitive processes, such as memory".
} 
ser animado ou inanimado. Nos dados, esse tem seu uso ampliado e passa a ser utilizado para retomar elementos apresentados anteriormente ou que será introduzido no texto analisados. Dessa forma, temos a confirmação, nos dados, de que o uso pode influenciar a gramática, já que há uma mudança morfossintática em curso, nesse caso. Chama a atenção que, em algumas ocorrências, o termo coisa seja empregado com a função de retomada, porém sem a presença da informação a que se faz referência. Essas informações são apenas uma introdução para algumas questões que serão detalhadas mais adiante. Aqui, visou-se, apenas, relacionar a teoria em foco com alguns pontos observados nos dados.

\subsubsection{Usage-Based Phonology (Fonologia baseada no uso)}

A Usage-Based Linguistic propõe a aplicação de suas bases epistemológicas para a análise da fonologia. Seu principal nome é a linguista Joan Bybee, que explica a Usage-based phonology em seu texto de 1999. Um dos pontos principais da $U B L$ é ser plausível em termos de psicolinguística, e o objetivo é explicar os mecanismos cognitivos e linguísticos envolvidos no uso da língua, da forma mais real possível. É possível aplicar esses conceitos básicos para as análises de cunho fonológico, tanto no nível fonético, quanto na relação entre fonologia e morfologia.

Outro ponto importante para a $U B L$ é a dimensão temporal. Bybee (1999) explica que a dimensão temporal desta vertente teórica reconhece que a língua é processada em tempo real, ou seja, no momento em que ela é usada. Assim, ela pode mudar o tempo todo, de acordo com o uso que lhe é feito, o que faz com que a gramática seja recriada a cada momento. A estudiosa valoriza a diacronia nos estudos linguísticos, já que mudanças diacrônicas são importantes para a análise da língua, sobretudo para descrever e comparar padrões.

A perspectiva de analise proposta na Fonologia Baseada no Uso guiará a análise que se pretende fazer sobre relação entre língua falada e língua escrita nesta pesquisa. Contudo, é importante considerar que esse modelo tem sido aplicado para explicar variações fonológicas no nível da palavra, relacionadas ao nível lexical, e não no nível suprassegmental.

Para esse modelo, a palavra é o objeto mínimo de análise, já que o fone acontece dentro de um contexto específico, assim, a mente armazena o conhecimento relativo à palavra e não o sinal sonoro acústico que cada letra (no texto escrito) produz na fala. Sobre isso, Miranda e 
Guimarães (2013:220) explicam que "a palavra é a unidade de categorização mental para a criança, ou seja, na aquisição da linguagem as sequências fonológicas são aprendidas como partes da palavra e não independentemente da palavra". Nesse sentido, é possível compreender que um processo de aquisição baseado em sílabas ou em unidades menores não seriam tão efetivos quanto um baseado nas palavras.

A Fonologia de Uso também postula que um item lexical corresponde a uma representação mental, e quanto maior o seu uso, mais consolidado e acessível cognitivamente esse item se torna. Além disso, esse modelo apresenta categorias variáveis que são gradientes, afetados pela natureza do uso, e não fonemas ou traços distintivos como os modelos de análise tradicionais propõem.

Segundo Cristófaro-Silva (2002), as representações mentais do léxico podem conter informações "sintáticas, semânticas, fonológicas, fonéticas e ortográficas". Assim, na análise da ortografia do português, por exemplo, faz sentido considerar que, com base na frequência de uso de um determinado item lexical, o aluno deveria ter uma representação mental ortográfica correta das palavras que mais usa. Seguindo esse raciocínio, palavras como 'você' deveriam ser representas mentalmente de forma correta, e, por consequência, reproduzidas corretamente na escrita.

\section{$1.4 \mathrm{O}$ texto como base de análise}

Como já foi mencionado, um dos pontos de investigação, aqui, será a influência da prosódia, da modalidade oral da língua, sobre a estruturação do texto escrito. A relação entre oralidade e escrita, no nível em que se propõe analisar, encontra eco em matrizes de avaliação de redação, como a do Exame Nacional do Ensino Médio (ENEM), na qual consta que

Outra diferença entre as duas modalidades diz respeito à constituição das frases. No registro informal, elas são muitas vezes fragmentadas, já que os interlocutores podem complementar as informações com o contexto em que a interação ocorre, mas, no registro escrito formal, em que esse contexto não está presente, as informações precisam estar completas nas frases. A entoação, recurso expressivo importante da oralidade, e as pausas, que conferem coerência ao texto, são muitas vezes marcadas, 
na escrita, por meio dos sinais de pontuação. Por isso, as regras de pontuação assumem também essa função de organização do texto ${ }^{18}$. (Brasil, 2013:11).

As bases conceituais relacionadas à compreensão de linguagem que aqui se assume já foram mencionadas, mas é preciso, ainda, trazer mais algumas referências teóricas que permeiam esta pesquisa. Assim, é importante destacar que a compreensão e a definição de texto estão alinhadas aos princípios da Linguística Textual de perspectiva sociocognitivointeracionista, de cujos princípios básicos convergem com os da $U B L$, para a qual "o texto passa a ser considerado o próprio lugar da interação e os interlocutores, sujeitos ativos que dialogicamente - nele se constroem e por ele são constituídos” (grifo da autora), conforme afirma Koch (2006: 33). É no texto que se dá o uso da língua e que emergem suas regras reais, não as descritas e (ou) prescritas nos manuais de gramática.

No presente trabalho, não se pode deixar de considerar a língua como um sistema simbólico, pois ela é ordenada por regras e constituintes, e se busca, aqui, verificar a influência das marcas prosódicas na organização textual escrita, afinal o uso primeiro da língua é feito por meio da fala, e não da escrita. Para o estudo analítico do texto em sua modalidade oral, faz-se necessário buscar os conhecimentos da área da Pragmática. Para tanto é importante considerar os estudos de Levinson (2007), sobretudo quando se pretende considerar a entonação como transmissora de informação e agente na construção de sentido do texto, prova disso é que a distinção de uma frase como afirmação ou pergunta, em alguns casos, acontece exclusivamente por meio da entonação, como na dupla apresentada na Figura 1.

\section{Pergunta: Ana chegou hoje?}

\section{Afirmação: Ana chegou hoje.}

Figura 1 - O papel da entonação: pergunta ou afirmação?

Isso corrobora a necessidade de se considerar o texto como o lugar da interação, pois é quando ela se processa que os elementos pragmáticos se constituem. Com isso, torna-se possível analisar, por exemplo, estratégias utilizadas para a alternância dos turnos de fala, as estratégias de polidez, e o fato de a ação ser realizada por meio da fala (dizer é fazer).

\footnotetext{
${ }^{18}$ A redação no ENEM 2013, disponível em http://download.inep.gov.br/educacao_basica/enem/guia_participante/2013/guia_de_redacao_enem_2013.pdf Acesso em 08 de abril de 2015.
} 
Ver o texto como lugar para a interação, e tê-lo como objeto de estudo, também direciona o olhar para o que se pretende nele analisar, principalmente no que diz respeito à sua modalidade oral. É visível que há uma ampliação nos estudos que se debruçam sobre essa, haja vista o projeto empreendido por Ataliba de Castilho para a produção da Gramática do Português Falado, na década de 90 do século XX.

Contudo, estudiosos da análise de textos (Marcuschi 2008 e Cagliari 2001) e da Conversação (Kerbrat-Orecchioni 2006) reconhecem que pouco tem sido investigado no que diz respeito aos seus elementos não verbais, ou paraverbais, como prosódia, assim como sua importância para o sucesso da interação. Cagliari e Massini-Cagliari (2001:01 ${ }^{19}$ ) afirmam que os elementos prosódicos têm estreita relação com a estrutura do texto, e Kerbrat-Orecchioni (2006: 41), que a entonação pode intervir na construção de sentido do texto, sobretudo nas informações implícitas em um diálogo, além de se unir à voz na função de "indicadores muito eloquentes do estado afetivo dos participantes".

Traçando um paralelo com o texto em sua modalidade escrita, um possível nível de análise acima da sentença - próprio da modalidade oral - é correspondente ao parágrafo. $\mathrm{Na}$ estruturação do texto escrito, é consenso considerar o parágrafo como uma unidade de organização baseada, idealmente, na direção argumentativa que o texto pode seguir, e sua progressão temática, ou seja, em como as ideias, ou informações, são desenvolvidas, e sobre isso é que tratará a subseção a seguir.

\subsubsection{O parágrafo no texto de modalidades escrita e oral}

A questão da paragrafação é de grande relevância para a organização do texto argumentativo, porém ainda é pouco clara para os alunos do sexto ano, como será apresentado na análise dos dados. Figueiredo (1999) afirma que a complexidade na organização e na materialização do parágrafo se deve ao processamento cognitivo do brasileiro, que vê o parágrafo como algo abstrato. Além disso, ainda segundo o autor, como o pensamento latino americano é menos direto e objetivo que o norte americano, há uma tendência para que os nossos parágrafos sejam mais robustos e, consequentemente, confusos (dada a sua grande

19 "O papel da tessitura dentro da prosódia portuguesa", no material cujo título é Razões e Emoção - Miscelânea de estudos oferecida a Maria Helena Mateus, Junho de 2001, do Departamento de Linguística Geral e Românica, FLUL. Disponível em http://ww3.fl.ul.pt/dlgr/arquivo/mateus/17.ps. Acesso em 20 de novembro de 2011. 
quantidade de justificativas e digressões) que os dos habitantes dos Estados Unidos. Relacionando-se essas ideias ao ensino de produção de texto no Brasil, que a cada resultado do ENEM recebe mais críticas, percebe-se que há necessidade de se investigar a paragrafação, bem como pensar em estratégias de ensino eficazes para os alunos.

Silva (2014), em sua tese de doutorado sobre paragrafação, argumenta que são escassos os estudos em relação ao parágrafo, o que confirma a necessidade de maior investimento nesse tema. Isso pode justificar a pouca ênfase dada a ele no ensino de produção de textos e na regularidade de informações, quando esse é abordado em alguns manuais. Em linhas gerais, os resultados observados na prática docente indicam que a escassez de investimento no estudo de parágrafo, em língua portuguesa do Brasil, está intimamente relacionada às dúvidas e às dificuldades dos alunos na produção e na organização do texto escrito.

Para confirmar seu argumento, Silva (2014: 76) empreende uma pesquisa bibliográfica sobre a paragrafação e obtém os seguintes resultados.

\begin{abstract}
Para discutirmos melhor a questão da paragrafação, realizamos um levantamento bibliográfico sobre o tema em várias fontes e com isso foi possível perceber que os estudos são escassos. Serviram de material de pesquisa obras de caráter mais instrucionais, ou seja, que visam oferecer ao aluno subsídios para o aprendizado (14 gramáticas, 4 dicionários, 7 manuais de redação); obras científicas (4); periódicos especializados da área de linguagem (Revista DELTA, Revista Linguagem e Ensino, Revista Linguagem em (DIS) curso, Revista Letras), cujos volumes se encontravam disponibilizados eletronicamente; o Banco de Teses e Dissertações da CAPES e os anais dos últimos cinco anos de dois grandes congressos da área educacional (as reuniões da Associação Brasileira de Pós-graduação em Educação - ANPED e os Encontros Nacionais de Didática e Prática de Ensino - ENDIPE).
\end{abstract}

No grupo das obras de caráter mais instrumental, normativo, encontramos autores como Melo (1980), Cunha e Cintra (1985), Mesquita e Matos (1987), Luft (1991), Tufano (1995), Mesquita (1997), Bechara (1999) e Vilela (1999), que não abordam em suas gramáticas esse conteúdo. Outros como Cegalla (1980) se referem ao parágrafo apenas como sinal gráfico responsável em marcar tópicos em leis. Ainda há autores pertencentes a esse grupo que apresentam o parágrafo como uma unidade de composição do texto, são eles: Abreu (1991); Almeida (1989); Cereja e Magalhães (1990) e Garcia (1970). Nas obras científicas (BESSONNAT, 1988, BAKHTIN, 2002; HOFFMANN, 2002; LIBERATO e FULGÊNCIO, 2007), todos os estudiosos pesquisados também apontavam o parágrafo como meio de organização do conteúdo textual $^{20}$.

\footnotetext{
${ }^{20}$ As obras mencionadas pela autora são, por ordem de citação: MELO, G. C. de. Gramática fundamental da Língua Portuguesa: de acordo com a nomenclatura gramatical brasileira.- 3. ed. - Rio de Janeiro: Ao Livro Técnico, 1980; CUNHA, C. e CINTRA, L. F. L. Nova Gramática do Português Contemporâneo. Rio de Janeiro: Nova Fronteira, 1985; MESQUITA, R. M. e MATOS, C. R. Gramática Pedagógica. - 14. ed. - São Paulo: Saraiva, 1987; LUFT, C. P. Moderna gramática brasileira. São Paulo: Globo, 1991; TUFANO, D. Estudos de Língua Portuguesa: gramática. 3. ed. - São Paulo: Moderna, 1995; MESQUITA, R. M. Gramática da Língua Portuguesa. São Paulo: Saraiva, 1997; BECHARA, E. Moderna Gramática portuguesa. 37. ed. Rio de Janeiro: Lucerna, 1999; VILELA, M. Gramática da Língua Portuguesa. 2. ed. Coimbra: Almedina, 1999; CEGALLA, D. P. Novíssima Gramática da Língua Portuguesa. São Paulo: Nacional, 1980; ABREU, A. S. Curso de Redação. São Paulo: Ática,
} 
Além dos materiais investigados pela pesquisadora em questão, pode-se acrescentar à lista dos que não abordam o conteúdo em foco: Azeredo (2008), Abreu (2003 [2012]) e Perini (2010). O manual prático de língua portuguesa elaborado por Martins \& Zilberknop (2010 $29^{a}$ edição) trabalha com a noção de parágrafo como unidade redacional, que serve para dividir e organizar o texto, e cada um trata de um enfoque específico do assunto do texto, ou seja, pode essa obra ser acrescentada dentre as que "apresentam o parágrafo como unidade de composição do texto", segundo proposição de Silva (2014: 76).

Dahlet, em seu artigo publicado em 2006 na Revista de Filologia Linguística Portuguesa, apresenta um histórico da organização textual, e defende que a paragrafação veio auxiliar o processo de leitura em voz alta de um texto. Para compreender o posicionamento da autora, é interessante considerar que, inicialmente, o ensino era realizado por meio de tutores, que liam os textos com seus alunos, e, nesse processo, surgiu a necessidade de pausas para comentários e compreensão do texto. A estudiosa defende também o parágrafo é o primeiro sinal de pontuação, afirmando que

\begin{abstract}
a história da paragrafação é exemplar, pois mostra as determinações que regem sua função, que é diretamente ligada às condições concretas de leitura. Essas condições concretas explicam a razão pela qual o parágrafo é o primeiro sinal de pontuação que apareceu nos textos, pois a ordem tabular, isto é, a introdução de marcas divisórias da escrita que permitiam ao escriba ou ao leitor referir-se diretamente a blocos textuais sem obrigação de retomar o texto desde seu início, respondia a uma necessidade prioritária em relação à segmentação de unidades textuais menores, seja a unidade frasal ou interna à frase. (2006:290).
\end{abstract}

A partir disso, compreende-se que os textos escritos eram, inicialmente, organizados em blocos únicos, que dificultavam intervalos durante a leitura em voz alta para que fossem feitos comentários e explicações, como mencionado no parágrafo anterior. Percebe-se, também, o caráter pedagógico da paragrafação, pois possibilita um diálogo entre quem lê e para quem se lê. Outro ponto que merece atenção é o fato de a paragrafação, bem como a pontuação, partir da necessidade da interlocução do autor com o leitor do texto e de favorecer a compreensão por parte, também, do leitor. Na fala, o leitor/ouvinte do texto ajuda na construção do próprio texto,

1991; ALMEIDA, N. M. de. Gramática Metódica da Língua Portuguesa. 36. ed. - São Paulo: Saraiva, 1989; CEREJA, W. R. e MAGALHÃES, C. T. A. Português: Linguagem: Literatura, Gramática e redação, v.3: 2o grau1. ed. São Paulo: Atual, 1990; GARCIA, O. M. Comunicação em prosa moderna - aprenda a escrever, aprendendo a pensar. 2. ed. Rio de Janeiro: Fundação Getúlio Vargas, 1970; BESSONNAT, D. Lé Découpage em paragraphes et ses fonctions. In: Pratiques, $n^{\circ}$ 57, Mars, 1988; BAKHTIN, M. Marxismo e filosofia da linguagem. $2^{\mathrm{a}}$ ed. SP: Hucitec, 2002; HOFFMANN, J. Da escola ao vestibular. Porto Alegre: Mediação, 2002; e LIBERATO, Y. e FULGÊNCIO, L. É possível facilitar a leitura: um guia para escrever claro. São Paulo: Contexto, 2007. 
já que, a partir de sua reação, é possível que o escritor/falante repense e refaça a estrutura e o conteúdo do texto. Contudo, na escrita, não há esse recurso, e o autor precisa ajudar o leitor a ler seu escrito, e para isso sua organização textual é muito importante. Esse ponto é interessante para a análise que se pretende fazer neste estudo, pois relaciona pontuação e organização textual na fala e na escrita.

Bakthin (2002: 141) também destaca o parágrafo como uma unidade, dentro de um discurso escrito, ou seja, dentro de uma comunicação, em que se valoriza a reação do leitor. Segundo ele, o parágrafo pode conter uma palavra ou uma série de orações complexas, a depender da comunicação na qual o parágrafo se insere. Além disso, o estudioso defende que a afirmação de que "o parágrafo deve conter a expressão de um pensamento completo não leva a nada", já que o parágrafo é uma organização linguística, e não há equivalência entre essa e o "pensamento completo". Essa disparidade entre "pensamento completo" e parágrafo faz com que haja uma explicação relacionada à linguagem para a noção de parágrafo (e não uma explicação relacionada ao pensamento), o que relaciona paragrafação à comunicação, a qual só existe e se processa por intermédio da linguagem.

Uma questão interessante para a análise dos dados, trazida por Bakthin (2002:141) é a noção de organização do discurso escrito e, por consequência, do parágrafo, com base na reação do leitor. Segundo ele, "quanto mais fraco o ajustamento ao ouvinte e a consideração das suas reações, menos organizado, no que diz respeito aos parágrafos, será o discurso". Essa ideia de Bakthin pode justificar o que os dados revelam em relação à paragrafação, já que os alunos do sexto ano têm pouca consciência da relação que se estabelece entre autor e leitor de um texto.

Com as informações apresentadas nesta subseção, pode-se perceber o caráter abstrato do parágrafo no texto escrito. Ou seja, trata-se de uma estrutura facilmente identificável, em um texto escrito, contudo especificar sua função, explicar seu uso e definir sua estrutura não são tarefas óbvias. Além disso, fica, mais uma vez, marcada a importância da comunicação para a estruturação da língua escrita, pois os parágrafos, assim como os espaços em branco entre as palavras, servem para atender a uma necessidade comunicativa, de colaboração com o leitor, não a uma exigência da estrutura. Isso demonstra a necessidade de se trabalhar sistematicamente a paragrafação em sala de aula, pois o aluno, no início do Ensino Fundamental II, tem seu processo cognitivo ainda muito centrado em elementos concretos - relacionados à materialidade de conceitos e às experiências vividas em sua rotina. Por essa razão, para eles, os conceitos abstratos, como a noção de Deus (se esse é um substantivo concreto ou abstrato), são de difícil apreensão. 
Outra possível análise do parágrafo é observá-lo na perspectiva de organização textual e sintática acima da sentença, essa unidade é, para Castilho (2010) e Castilho \& Elias (2012), uma transposição - ou correlação - na escrita, das unidades discursivas da fala. Para a compreensão dessa definição, é preciso ter claros alguns conceitos que os autores abordam, como os que seguem.

1. Tópico discursivo: assunto, tema, que foi considerado relevante pelos locutores, e que está sendo utilizado para estruturar o texto em produção. No discurso, o tópico é o assunto, o tema, à volta do qual giram as intervenções; ele é fundamental para a organização da unidade discursiva. Na gramática (tradicional), o tópico, tema ou sujeito sentencial é o constituinte sobre o qual o verbo declara alguma coisa; ele é fundamental para a organização da estrutura funcional da sentença. Quando localizado fora da sentença, ele é chamado de construção de tópico, funcionando como uma ponte estendida entre o texto e a sentença, vale dizer, entre o Discurso e a Gramática.

2. Unidade discursiva: um segmento do texto caracterizado por reunir um grupo de sentenças que elaboram o tópico, preservando a coerência temática da unidade maior, que é o próprio texto. Formalmente, a unidade discursiva se compõe de um núcleo e de duas margens, sendo facultativa a figuração destas. As margens são tomadas pelos marcadores discursivos. As unidades discursivas são próprias do texto oral, ou fala.

3. Quadro Tópico: conjunto de tópicos desenvolvidos nas unidades discursivas.

Ainda segundo esses estudiosos, os parágrafos/unidades discursivas formam o texto, que pode ser composto por uma ou mais de uma dessas estruturas. Os parágrafos, assim como os textos, possuem propriedades tais como: conectividade conceitual (ou coerência) e conectividade sequencial (ou coesão). Apresentam também diferentes tipologias, dependendo da intenção comunicativa do discurso, sendo, ao menos: a descrição, a narração e a argumentação (ou dissertação).

Considerando-se os estudos de Fávero et al (2007), o parágrafo é uma das unidades de construção do texto escrito, e é composto por um ou mais períodos reunidos em torno de ideias estreitamente relacionadas. Nos textos bem formados, em geral, a cada parágrafo deve 
relacionar-se uma ideia importante, não havendo normas rígidas para a paragrafação. De fato, o produtor pode fazer uso desse recurso para marcar sua intencionalidade.

Para as autoras, o parágrafo é identificado no texto por recursos visuais: entrada junto à margem esquerda ou linha em branco na passagem de um parágrafo para outro. A extensão do parágrafo é variável, e sua estrutura padrão é similar à de um pequeno texto, apresentando introdução, desenvolvimento e conclusão.

Fávero et al observam que a elaboração de um texto escrito, assim como a de um texto oral, envolve um objetivo ou intenção do locutor. Isso implica uma diversidade de textos, e, consequentemente, uma diversidade de estruturação dos parágrafos. Assim, há parágrafos dissertativos (cujo núcleo é uma determinada ideia), narrativos, que têm como núcleo um incidente (as autoras definem incidente como um episódio curto ou fragmento de episódio), e os descritivos. Esse último tem como núcleo um quadro, que, para Fávero et al, é um "fragmento de paisagem, ambiente ou ser num determinado instante, observado a partir de determinada perspectiva" (2007: 25).

Por ser o texto escrito uma interação a distância, em que não há a participação direta e imediata do interlocutor, diferente do texto oral, a construção de um parágrafo bem estruturado exige que ele apresente as seguintes características.

\footnotetext{
Unidade. Cada parágrafo pode conter somente uma ideia principal. As ideias secundárias devem estar relacionadas à principal, sem acréscimos ou digressões que possam quebrar a unidade pretendida.

Coerência. A organização do parágrafo deve ser feita de tal forma que fique evidente o que é principal. É indispensável que haja relacionamento de sentido entre a ideia principal e as secundárias desenvolvidas no texto.

Concisão. O parágrafo deve conter a quantidade de informação adequada ao objetivo do texto. A concisão, porém, não deve ser alcançada em detrimento da clareza.

Clareza. A escolha das palavras adequadas ao contexto concorre, em grande parte, para que o parágrafo se torne claro e a sua leitura possa ser feita de maneira eficiente, atingindo a compreensão (p. 29).
}

As autoras também defendem que, na organização do texto, as ideias precisam estabelecer um encadeamento lógico e natural, de forma que a transição de um parágrafo para o outro não deve ser brusca. Outras indicações importantes sobre organização textual ensinadas por Fávero et al postulam que em alguns casos é importante acrescentar ao texto um parágrafo de transição entre as ideias, ou argumentos defendidos, para que seu encadeamento se faça de maneira coesa e harmoniosa. As estudiosas (2007: 29) também afirmam ser aconselhável "que 
o texto não apresente parágrafos repetitivos sem necessidade, pois a repetição pode interromper o fluxo informacional, tornando o material redundante e cansativo".

Outro estudioso do texto, fundamental quando se fala em produção de textos na modalidade escrita, é Othon Moacyr Garcia. Há, na 26ª edição, lançada em 2006, de sua obra, uma análise do parágrafo - na terceira parte. Ele inicia sua explanação afirmando ser essa unidade de composição complexa de se definir, dada a existência de "vários processos de desenvolvimento e encadeamento de ideias" (2006: 219). Isso propicia a existência de vários critérios e estruturas possíveis para a organização de parágrafos. Assim, a busca por definições que caracterizem o parágrafo encontra na recorrência de determinado arranjo ou - estrutura a base para a sua sistematização. ${ }^{21}$

A principal função do parágrafo é organizar as informações e as ideias trabalhadas pelo escritor em seu texto. Por meio dos parágrafos, o escritor consegue, dentre outras possibilidades, hierarquizar seus argumentos, o que pode causar efeitos de ênfase a determinada ideia em detrimento de outra, também explorada no texto. Isso ajuda o leitor a compreender e a acompanhar o desenvolvimento do pensamento do escritor.

Pode-se observar uma íntima relação entre a extensão do parágrafo e a complexidade do assunto nele abordado, isso pode ser relacionado à Iconicidade, em seu subprincípio da quantidade, conceitos pertinentes à $U B L$. Defende-se, então, que as ideias mais densas e complexas tendem a propiciar parágrafos mais extensos que as mais simples. Isso faz com que haja parágrafos de três linhas, assim como de vinte. Contudo, eis um ponto que merece reflexão, pois nem sempre (a depender do assunto desenvolvido no texto) é possível correlacionar o grau de complexidade de um assunto à justificativa da extensão de um parágrafo.

Segundo Garcia (2006: 222), o parágrafo-padrão seria "aquele de estrutura mais comum e mais eficaz". Ele considera que, na dissertação e na descrição, a estrutura mais produtiva de parágrafos seria:

\begin{abstract}
a introdução, representada na maioria dos casos por um ou dois períodos curtos iniciais, em que se expressa de maneira sumária e sucinta a ideia-núcleo, o desenvolvimento, isto é, explanação mesma dessa ideia-núcleo; e a conclusão, mais rara, mormente nos parágrafos pouco extensos ou naqueles em que a ideia central não apresenta maior complexidade.
\end{abstract}

Alguns livros de produção de texto (Louzada, Goldstein \& Ivamoto 2009) trazem, em sua explicação sobre o parágrafo, essa definição proposta por Garcia. Sobre isso, vale

\footnotetext{
${ }^{21}$ Convém notar que esses arranjos (parágrafos) são frequentes em textos modernos, e não abrange textos clássicos da literatura de língua portuguesa, como Camões.
} 
considerar que alguns conceitos são de cunho semântico, o que pode ser pouco eficaz para o aluno que inicia seus estudos sobre a estruturação do texto. Eficácia do parágrafo e frequência das ocorrências de determinada estrutura, por exemplo, são critérios pouco claros, pois o que é eficiente para um leitor, pode não ser para outro. E a predominância de certa estrutura pode estar relacionada aos gêneros textuais a que os alunos são expostos. Assim, percebe-se que inconsistências conceituais como essas podem agravar a dificuldade dos alunos em se relacionarem com a produção de textos.

Outro conceito explorado por Garcia é o de tópico frasal, parte do parágrafo padrão que "encerra de modo geral e conciso a ideia-núcleo do parágrafo". Geralmente ele é formado por um ou dois períodos curtos, e esses se localizam no início do parágrafo. Contudo, a localização do tópico frasal pode variar de acordo com a intencionalidade do autor do texto. O tópico frasal pode ser também um limitador dos argumentos que o autor do texto pode trazer ao parágrafo, pois não se pode ir além da ideia principal daquele trecho do texto. Quando se faz um esquema de texto, o que se faz é isolar os tópicos frasais que serão ou foram desenvolvidos em cada parágrafo, facilitando, assim, a sumarização ou resumo do texto.

Observa-se que Garcia explora amplamente a questão do parágrafo, trazendo informações também relativas à sua coesão e à sua coerência, tendo como base sempre o texto escrito. Assim, o autor defende que é possível depreender que o parágrafo é uma estrutura própria dessa modalidade linguística, não havendo relação com o texto falado. A posição de Garcia é fundamental para a pesquisa desenvolvida aqui, uma vez que se pretende testar a validade dessa afirmativa, e buscar no texto oral estruturas equivalentes ao parágrafo do texto escrito.

O guia do participante de uma das avaliações mais importantes da educação brasileira atual, o já mencionado ENEM, relaciona a organização dos parágrafos com o encadeamento de ideias. Assim, avalia essa estrutura nas competências 3, em que se deve selecionar, relacionar, organizar e interpretar informações, fatos, opiniões e argumentos em defesa de um ponto de vista; e 4, na qual se exige demonstrar conhecimento dos mecanismos linguísticos necessários para a construção da argumentação.

O mesmo guia busca orientar os candidatos ao exame a produzirem textos dentro dos critérios que serão analisados. Em relação à competência 3, são dadas as seguintes instruções:

na organização do texto dissertativo-argumentativo, você deve procurar atender às seguintes exigências: apresentação clara da tese e seleção dos argumentos que a sustentam; encadeamento das ideias, de modo que cada parágrafo apresente informações novas, coerentes com o que foi apresentado anteriormente, sem 
repetições ou saltos temáticos; congruência entre as informações do texto e a realidade; e precisão vocabular. (Brasil, 2013: 18)

Já na competência $4^{22}$, o foco em relação ao parágrafo é em como esse deve ser estruturado e como a coesão é conduzida a partir da relação entre os parágrafos e internamente a ele. As informações apresentadas retomam conceitos clássicos sobre a estruturação do parágrafo, o que reforça a necessidade de estudos que possam lançar novo olhar sobre o tema. O guia do participante ensina que

um parágrafo é uma unidade textual formada por uma ideia principal à qual se ligam ideias secundárias. No texto dissertativo-argumentativo, os parágrafos podem ser desenvolvidos por comparação, por causa-consequência, por exemplificação, por detalhamento, entre outras possibilidades. Deve haver uma articulação entre um parágrafo e outro. (Brasil, 2013: 20)

As informações apresentadas para o ENEM são direcionadas aos participantes, ou seja, alunos concluintes da educação básica. Nota-se que esses alunos devem compreender os conceitos apresentados, como articulação entre os parágrafos, encadeamento de ideias e ideia principal e secundária. São questões relacionadas à coesão e à coerência textuais, conceitos abstratos, difíceis de os alunos compreenderem sem a intervenção docente, e que precisam ser trabalhadas ao longo de todo o percurso escolar.

\subsubsection{O parágrafo no ensino de Língua Inglesa para o sexto ano}

Os alunos cujos textos compõem os dados desta pesquisa são clientes de um ensino bilíngue, em que a língua inglesa é ensinada como língua materna, assim como o português. No currículo internacional, eles aprendem a noção de organização textual de texto argumentativo, nomeado de Persuasive Writing. A escola adota, como livro didático de língua inglesa para o sexto ano, o material “Write source, a book for writing, thinking, and learning”.

A ordem em que os conteúdos são abordados nas disciplinas de língua inglesa e língua portuguesa não é igual, de forma que, enquanto na primeira é ensinado Persuasive Writing, a segunda trabalha com texto narrativo, mais especificamente, o relato de aventura. Isso faz com

\footnotetext{
${ }^{22}$ É importante destacar que o foco da competência 4 é a coesão textual, que tem no parágrafo um de seus recursos. Neste trabalho, o foco é o parágrafo, por isso decidiu-se verificar como esse é enfocado também em relação à coesão, no Guia do Participante do ENEM.
} 
que os alunos conheçam a paragrafação de tipo argumentativo no modelo americano antes de trabalhar a mesma estrutura em língua portuguesa. Assim, poder-se-ia supor que há transferência de saberes, e que, ao elaborarem textos argumentativos em língua portuguesa, a mesma estrutura do parágrafo em língua inglesa seria mantida. Contudo, como será discutido mais adiante, não é isso que os dados indicam.

O material didático de língua inglesa se inicia com uma mobilização do aluno para a escrita, e passa três páginas apresentando razões para se comunicar por meio dessa variação da língua. Em seguida, os autores dedicam um capítulo de 64 páginas para a explicação do que é o processo de escrita, como ele se dá, como utilizar os critérios de correção que o próprio material propõe, além de oferecer um panorama geral do trabalho que será desenvolvido e apresentar modelos de produções, que ilustram o que está sendo explicado.

Outro ponto abordado logo de início no material didático em foco é como os alunos produzirão seus textos escritos e os cinco $\operatorname{passos}^{23}$ (planejamento, escrita, revisão, edição e publicação) que eles seguirão durante o trabalho que se inicia. Nesse momento, os autores apresentam também como cumprir cada etapa da produção de texto, com informações sobre como ser um bom escritor, e ensinam a noção de tópico, muito relevante para a abordagem proposta.

Logo no índice do livro, é possível perceber que a organização do parágrafo é trabalhada juntamente com a tipologia enfocada em cada capítulo. Assim, o parágrafo argumentativo é ensinado juntamente com a lição de como promover uma causa e como escrever um ensaio sobre injustiça com animais domésticos. Nesse ponto, o material demonstra que a tipologia enfocada tem relação prática com a vida dos alunos, já que é a oportunidade que esses têm de mostrar, às outras pessoas, aquilo que pensam sobre alguns assuntos. Além disso, o material relaciona o parágrafo argumentativo com outras áreas do conhecimento, mostrando como ele pode ser usado em disciplinas como Matemática e Estudos Sociais (Social Studies).

As imagens subsequentes são fotos do material didático em foco e mostram como a organização do texto argumentativo é apresentada ao aluno e trabalhada em aula. As estratégias ensinadas confirmam a análise de Figueiredo (1999), mencionada na subseção anterior, sobre a organização do pensamento americano e como isso se reflete no texto escrito, em contraponto com o modo de pensar menos objetiva dos latino americanos. Observa-se que, antes de o material didático em foco explicar ou definir o texto persuasivo, os alunos são expostos a três

\footnotetext{
${ }^{23}$ Prewrinting, writing, revising, editing and publishing.
} 
perguntas, traduzidas a seguir. Nesse enfoque, as perguntas feitas expõem os alunos à tipologia textual a ser trabalhada e os conduzem a uma linha de raciocínio argumentativa.

(a) Se você pudesse mudar uma coisa em sua escola ou casa, o que você mudaria?

(b) Como você poderia fazer essas mudanças?

(c) Você acredita que poderia convencer outras pessoas a aderirem à mudança que você propõe?

\section{Persuasive Writing}

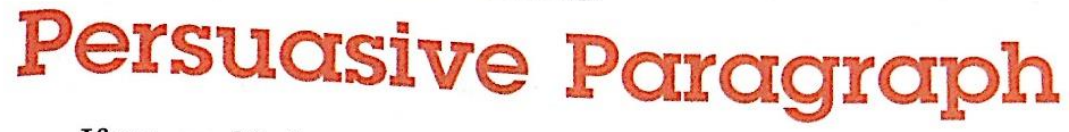

If you could change one thing at school or at home, what would it be? How would you change it? Do you think you could convince other people to go along with the change?

Persuasive writing is your chance to get people to think the way you do about something. Advertisements, editorials, and even some letters are common kinds of persuasive writing.

In the next few pages, you'll write a persuasive paragraph about a change you'd like to make.

\section{Writing Guidellines}
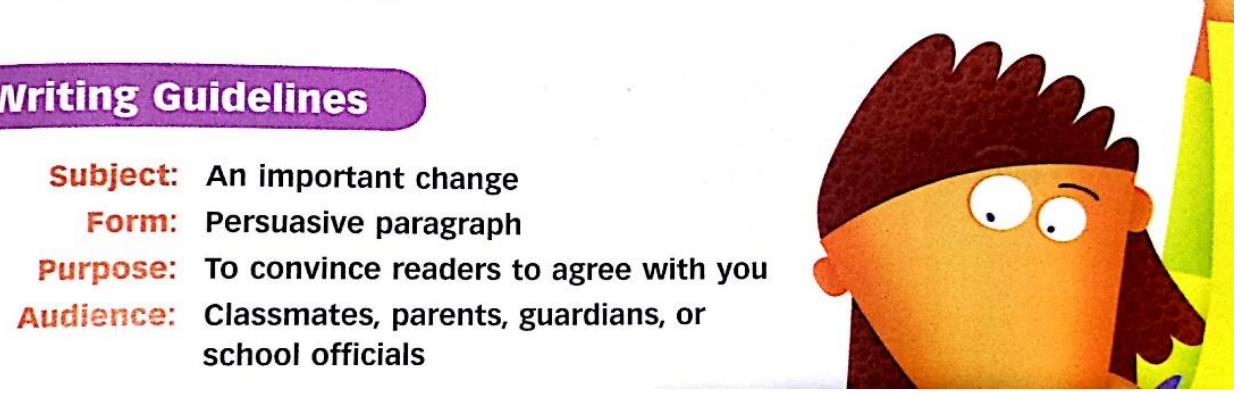

Figura 2 - Write source, a book for writing, thinking, and learning, página 219

Além das perguntas direcionadoras, o material também deixa claro como o parágrafo persuasivo deve ser elaborado, com a função e o público alvo bem definidos. Assim os estudantes têm bem delimitadas as atividades que deverão fazer e o caminho que deverão trilhar para o desenvolvimento de seus textos.

O material didático em foco parte da apresentação de um modelo exemplar, e a metodologia empregada pela Escola Internacional era bastante enfática na necessidade de se apresentar para os alunos um exemplo com alto nível de qualidade, para que esse seja a meta a se atingir. A figura a seguir ilustra esse procedimento metodológico, no qual se pode observar 
que o aluno parte da análise do modelo, para que tenha clara noção de que estruturas precisará utilizar em seu texto.

\section{Persuasive Paragraph \\ In a persuasive paragraph, the topic sentence states an opinion, the body sentences give reasons to support it, and the closing sentence restates the opinion. The following paragraph was written by a student concerned about access to the school stage.}



Figura 3-Write source, a book for writing, thinking, and learning - página 220

Com base no que o livro didático de Língua Inglesa apresenta, o aluno do sexto ano é conduzido a perceber o parágrafo argumentativo como um bloco de informações formado por várias frases curtas, as quais compõem elementos básicos desse tipo de estrutura, que são o 
tópico frasal, o desenvolvimento (o corpo do parágrafo) e a frase de fechamento. Em seguida, o material analisa o parágrafo lido, para identificar alguns pontos importantes dessa estrutura.

É importante ter clareza de que os alunos, antes de trabalharem sistematicamente o parágrafo argumentativo nas aulas de língua portuguesa, como já foi mencionado, trabalharam o parágrafo persuasivo em inglês. Por isso, a expectativa para a análise de dados era que houvesse uma transposição de conteúdo entre os idiomas, já que o conhecimento não é compartimentado. Contudo, como será apresentado na análise de dados, isso não aconteceu, diferente das ocorrências que dizem respeito à transferência de aspectos segmentais da língua inglesa para a língua portuguesa.

A maneira de conduzir o trabalho com parágrafo persuasivo proposta, no material em análise, foi uma das inspirações para algumas das atividades propostas durantes as aulas de Língua Portuguesa, para o ensino da paragrafação. Um exemplo dessa adaptação será apresentado no Capítulo 5 desta tese, que é dedicado a propostas de intervenção didática para o aprimoramento da produção de textos escritos dos alunos de sexto ano.

\subsubsection{O parágrafo no ensino de Língua Portuguesa para o sexto ano}

As três turmas de sexto ano analisadas utilizaram, como livro didático, o material "Para viver juntos", da editora Edições SM. A edição adotada foi a comercializada em 2014, já que, para o no letivo de 2015, o material foi um pouco reformulado ${ }^{24}$. O material tem como base teórica a análise textual e a análise discursiva, embora recorra à metalinguagem, sobretudo, para a explicação de assuntos gramaticais, enfocados conforme a gramática tradicional. O programa nacional de livro didático, ano 2014, trouxe o material em seu guia de livros e, sobre a coleção "Para viver juntos", informa que

\footnotetext{
Visando ao desenvolvimento de capacidades de uso da língua, as atividades de leitura e de produção de textos escritos, nesta coleção, têm como diretriz o trabalho com gêneros textuais próprios de diferentes esferas discursivas. Nesses dois eixos de ensino, o trabalho é proposto de forma articulada, pois os gêneros explorados nas atividades de leitura são os mesmos solicitados na escrita, e alguns dos gêneros produzidos são socializados por meio de atividades associadas à leitura. As propostas
}

\footnotetext{
${ }^{24}$ A reformulação não modificou todo o livro e é possível perceber a manutenção de sua base teórica e da maioria dos textos e atividades propostas. Observou-se que o maior incremento do material, comparando-o com a edição anterior, foi em relação à abordagem da oralidade, que aparece de forma mais sistematizada em enriquecida em sua nova edição e em relação à adequação de usos da linguagem.
} 
contemplam o modo organizacional e as condições de produção desses gêneros e consideram as estratégias e os procedimentos linguísticos implicados tanto na compreensão como na produção textuais. (Brasil, 2013: 74).

Além disso, o referido guia sintetiza as principais características do material, apresentando-as no quadro a seguir apresentado.

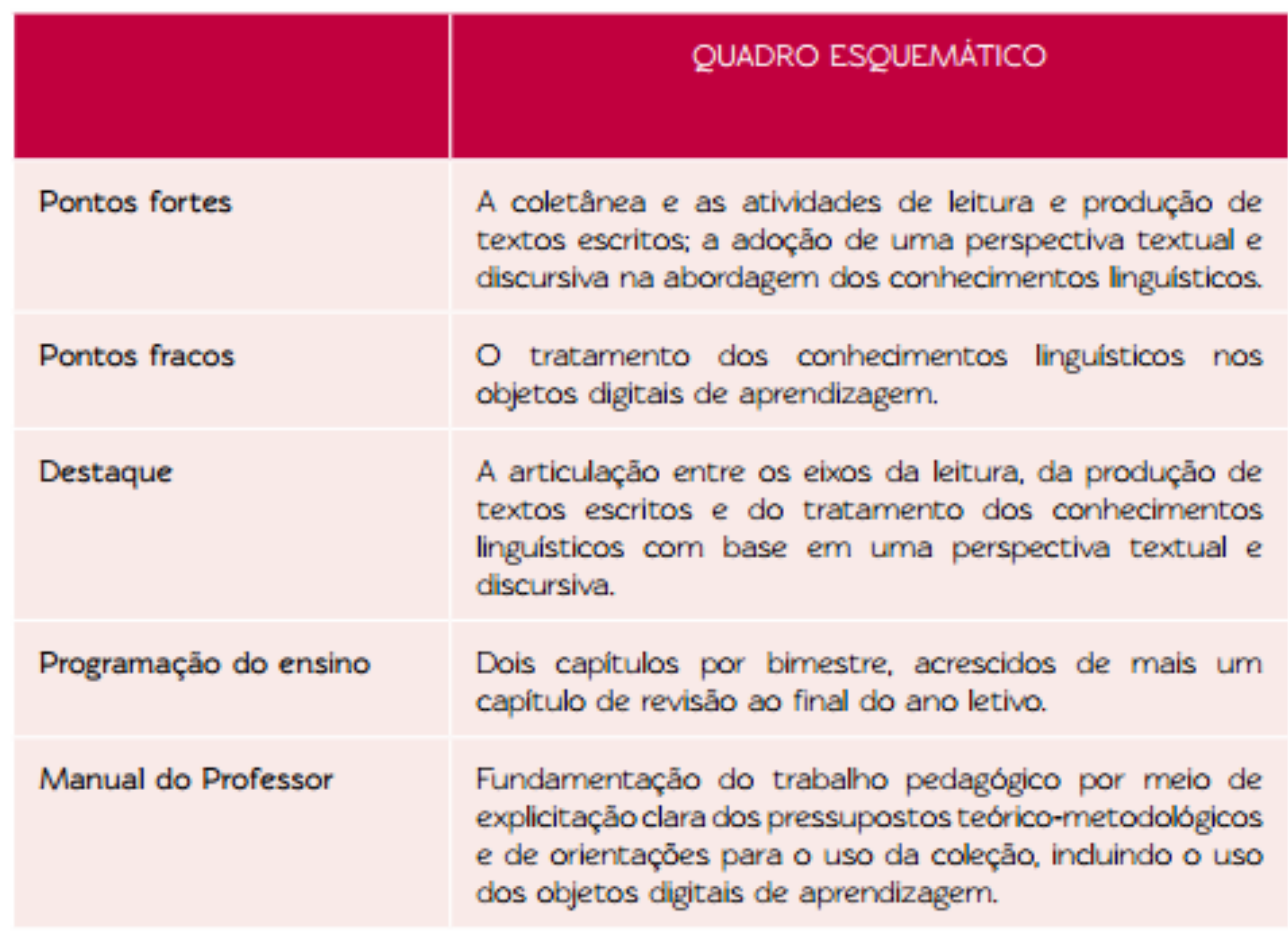

Figura 4 - Guia de Livros Didáticos PNLD 2014, página 75.

A Escola Internacional ${ }^{25}$ adotou esse material para o ano letivo 2014/2015, em substituição ao que era utilizado até então. A troca de material foi feita com base na vertente de ensino que se pretendeu imprimir à disciplina de língua portuguesa, em que se priorizasse o discurso como base de análise da língua e também os gêneros textuais como formas de comunicação. Assim, a linguagem passaria a ser ensinada na perspectiva do uso, na comunicação, o que proporcionaria ao aluno uma visão de teoria e prática integrada, em que a estrutura gramatical é justificada pelo uso que se pretende fazer da língua portuguesa, sobretudo da língua escrita.

A escola adotava, até então, o ensino de língua portuguesa focada na forma, tendo a gramática normativa como principal enfoque, em uma abordagem do texto como pretexto para

${ }^{25}$ Pseudônimo da escola em que a pesquisa foi realizada. Maiores informações sobre o locus da pesquisa são encontradas no Capítulo 3 (Metodologia). 
o ensino da estrutura da língua. Em avaliações internas e externas, promovidas pela escola, ficou claro que a metodologia utilizada não era a mais eficiente, já que os alunos alcançavam resultados abaixo do esperado em relação ao uso e à análise da língua portuguesa.

A troca do material didático foi acompanhada de uma alteração também na forma de a equipe de língua portuguesa olhar para o ensino que se iria praticar, pois o material didático é o que o professor faz dele. Nesse ponto, foi interessante que o docente tenha levado os pressupostos teóricos relativos aos gêneros textuais e à análise linguística para estudo dos docentes de Língua Portuguesa.

Essas informações acerca do material escolar e da linha teórica que norteia o ensino de língua portuguesa na EI tiveram o objetivo de introduzir o tratamento do parágrafo nesse contexto de ensino. Considerando-se as condições expostas, a expectativa de pesquisa era encontrar no material didático o ensino direcionado da produção de texto, que passasse pela organização do parágrafo, já que essa é uma das unidades constitutivas do texto escrito, com importância discursiva e que tem o leitor, ou seja, o interlocutor, como foco, como apresentado na subseção 1.4.1.

O livro didático "Para viver juntos" propõe trabalho coerente à proposta teórica do material didático. $\mathrm{O}$ aluno é exposto ao gênero e ao tipo textual que estão sendo enfocados no capítulo, esses são analisados e, por fim, há o convite para que o aluno produza um texto com o que lhe foi ensinado, e essas etapas são feitas com qualidade. Contudo, não há um enfoque em relação às unidades que constituem o texto, como o parágrafo, que é considerado (pelo material) como um conhecimento prévio do aluno ao ser mencionado em atividades de produção do texto. Nota-se que o livro não trata o parágrafo como unidade discursiva que necessita ser analisada e ensinada ao aluno de sexto ano. Como é possível se verificar o sumário do livro apresentado no Anexo 2, o estudo dos alunos se inicia com a narrativa de aventura e termina com o texto argumentativo sendo trabalhado juntamente com a entrevista, no último capítulo do livro que traz conteúdo novo, pois o último capítulo, de fato, é uma revisão de tudo o que foi estudado.

Como mencionado, não há, no material, seção dedicada ao trabalho com o parágrafo e sua estruturação, diferentemente do que foi observado no livro didático da língua inglesa. Outro ponto divergente entre os materiais é que, no livro de Língua Portuguesa, a argumentação é trabalhada dentro do gênero entrevista, e os argumentos apresentados, com os quais os alunos devem trabalhar, são os do entrevistado, e não os dos estudantes. Ou seja, nessa abordagem, os alunos não terão que se posicionar sobre algo, mas sim trabalhar com os argumentos de outra 
pessoa. Já no material de Língua Inglesa, os alunos precisam apresentar seu ponto de vista sobre determinada temática, como apresentado na subseção 1.4.2.

Observou-se que o livro "Para viver juntos" menciona a necessidade de se organizar um texto em parágrafos apenas quando enfoca o gênero textual notícia, na página 140. Até então o gênero narrativo foi exaustivamente trabalhado, e somente quando o foco recai sobre textos informativos é que se menciona o parágrafo, e, ainda assim, na proposta de produção de texto, como apresentado a seguir.

\footnotetext{
eee Proposta

Você e seus colegas vão escrever um jornal que será distribuído entre os jovens que moram perto da escola. As notícias serão divididas em cadernos com temas de interesse da comunidade local.

Observe os cadernos dos jornais. Qual deles apresenta temas de interesse para os jovens que serão os leitores do jornal produzido pelos alunos de sua classe?
}

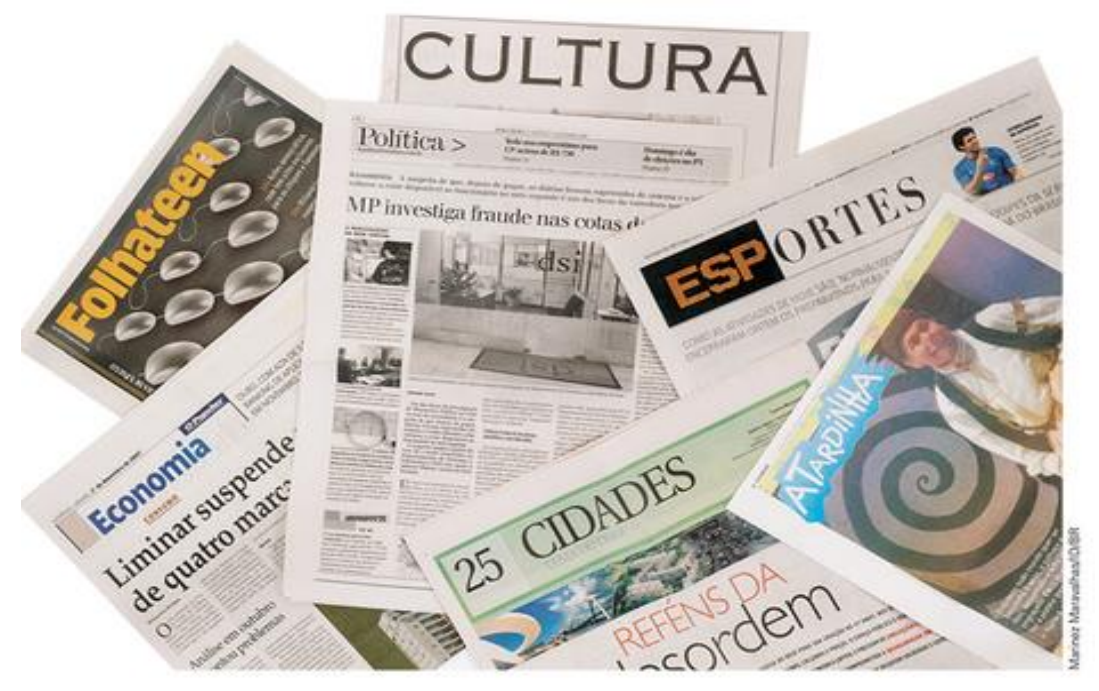

•૯ Planejamento e elaboração do texto

1. Faça uma lista de assuntos que seriam de interesse da comunidade que mora perto da escola. Apresente suas ideias para seus colegas. Por exemplo: mudanças na coleta de lixo, distribuição de alimentos na creche do bairro, exposição de arte nas escolas, etc.

140

Figura 5 - Livro didático "Para viver juntos", para o sexto ano, 2014, página 140. 
2. Escolha um dos assuntos sugeridos pela classe para escrever sua notícia.

3. Planeje seu texto levando em conta os seguintes itens.

a) Título que atraia o leitor.

b) Olho da notícia.

c) Lide.

d) Corpo da notícia.

e) Fotografia que ilustre o fato.

f) Legenda.

4. Após planejar seu texto, escreva a notícia.

a) Lembre-se de que no lide deverão constar as informações principais da notícia. Nos parágrafos seguintes, você desenvolverá o corpo da notícia.

b) Utilize o verbo em terceira pessoa para dar objetividade ao seu texto.

c) Lembre-se de que a seleção de palavras pode revelar a posição de quem escreve a noticia em relação ao acontecimento noticiado.

\section{Avaliação e reescrita do texto}

1. Releia o seu texto e observe os seguintes aspectos.

a) $\mathrm{O}$ assunto escolhido é de interesse dos jovens que moram perto da escola?

b) A linguagem está adequada ao público leitor?

c) Você acrescentou fotografias ou ilustrações a sua notícia?

d) As legendas ampliam as informações da(s) fotografia(s)?

2. Depois de avaliar seu texto, faça as modificações que considerar importantes.

3. O texto deve ser digitado ou pode ser escrito em folhas de papel sulfite.

Figura 6 - Livro didático "Para viver juntos", para o sexto ano, 2014, página 141.

Essa abordagem confirma que a noção de parágrafo é considerada como conhecimento prévio que o aluno deve dominar, ao iniciar o sexto ano. No material, sem explicação acerca da função ou da estrutura paragrafal, o estudante é convidado a elaborar uma notícia, em que os parágrafos seguintes à lide constituirão o corpo do texto.

Considerando-se a tipologia em foco, nota-se que ela é trabalhada de forma diversa à do livro didático de Língua Inglesa. Ao contrário do que ocorre no material "Write source, a book for writing, thinking, and learning”, o parágrafo argumentativo não é sistematizado para o público-alvo, tampouco analisa-se um modelo ideal. Além disso, a argumentação é trabalhada, no material de Língua Portuguesa como apresentado na figura a seguir, que é uma página do livro abordado.

A proposta do material didático de Língua Portuguesa é que o aluno conheça a argumentação a partir do gênero textual entrevista. Assim, é apresentada uma entrevista com a cantora Fernanda Takai, e a partir dela a argumentação é trabalhada. Aqui não será apresentada a entrevista mencionada, mas sim as atividades propostas a partir dela. 
1 Ponto de vista e argumentação

1. Em vários trechos da entrevista são apresentadas as opiniões de Fernanda Takai. Releia a seguinte fala:

"Acho que hoje está claro pra todo mundo que nosso mentor é o John! [...] Acho ótimo que estejam surgindo novos nomes femininos, quanto mais gente melhor. Mais garotas se sentirão incentivadas!"

a) Sobre quais assuntos a cantora expressa suas opiniões nesse trecho?

b) Ela justifica tais opiniöes? Explique.

A entrevista muitas vezes apresenta a opiniảo ou o ponto de vista do entrevistado. Dessa maneira, podemos conhecer o modo como ele vê o mundo, seus gostos, suas ideias.

2. Algumas opiniōes são justificadas com exemplos. Complete o esquema a seguir, revendo as opiniões e os argumentos que aparecem nas falas de Fernanda e do entrevistador.

a) Afirmaçăo de Fernanda Takai.

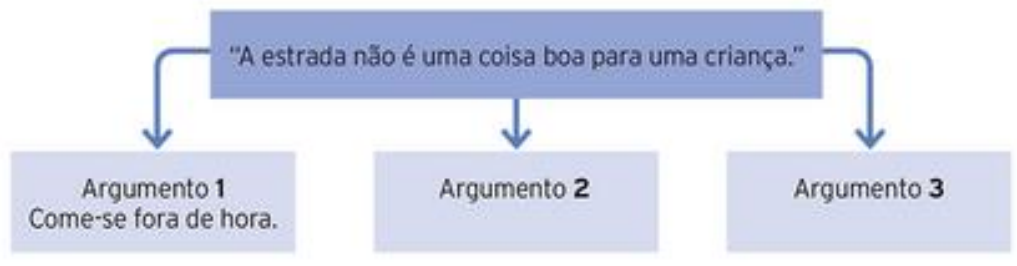

260

Figura 7 - Livro didático "Para viver juntos", para o sexto ano, 2014, página 260.

As atividades propostas acima compõem o primeiro momento em que o material didático sistematiza o trabalho com a apresentação de opiniões e pontos de vista. Observa-se que o aluno é convidado a perceber, inicialmente, como a opinião da entrevista é apresentada no texto. Em seguida, há uma informação de cunho teórico que relaciona entrevista e exposição de ponto de vista. O passo seguinte apresenta ao aluno a organização de parágrafo argumentativo, em que se faz uma afirmação e, no desenvolvimento da estrutura, se apresentam exemplos que podem confirmar, ou refutar, o ponto de vista defendido pela entrevistada. No exercício, o aluno deve identificar os exemplos apresentados em relação à afirmativa "A estrada não é boa para uma criança", que funcionarão como argumentos para a defesa da opinião. Com essa abordagem, o aluno será guiado na construção do texto argumentativo, porém é preciso ponderar que essa atividade é programada para ser realizada na Etapa 4 do ano letivo, o que confirma o que já foi mencionado nesta tese: é preciso trabalhar argumentação com os alunos de sexto ano desde os primeiros momentos do ano letivo. 
A abordagem proposta no material é interessante, pois faz com que o aluno tenha contato com o que é argumento para, depois, elaborar sua própria defesa de ponto de vista. Contudo, a argumentação é uma ação frequente no cotidiano dos alunos da faixa-etária investigada, já que estão, frequentemente, querendo convencer seus pais e professores de seus argumentos. Nesse aspecto, vale mencionar que o grupo analisado era especialmente "argumentador", quando comparado com alunos da mesma faixa etária, de anos letivos anteriores. Era frequente os alunos reivindicarem espaço, inclusive junto à coordenação, para obter benefícios e direitos, como realizar certas atividades durante o recreio e poder escutar música enquanto faziam os exercícios das aulas. Isso demonstra como argumentar é familiar ao aluno do sexto ano, e que, mais que sustentar uma opinião, eles objetivam intervir no comportamento do outro, ou seja, persuadir, como trabalhado na disciplina de Língua Inglesa. Dessa forma, se é tão familiar a argumentação, por que trabalhá-la a partir do ponto de vista de outra pessoa, como propõe o material utilizado? Pode ser mais interessante partir da prática discursiva do ponto de vista e da vivência do próprio aluno, com base em seu conhecimento de mundo.

Dentro da proposta de trabalho do material "Para viver juntos", o parágrafo é tido, como já mencionado, como conhecimento prévio e o aluno não é levado a perceber que os tipos de parágrafos variam conforme a tipologia textual a que serve. A partir das atividades propostas apresentadas nas figuras, nota-se que predomina o ensino pouco reflexivo acerca das estruturas da língua, apesar de todo o referencial teórico centrado no discurso que o material analisado traz. A manutenção do modelo tradicional, de ensino ilustrado pela Figura 8, corrobora o caráter abstrato da paragrafação, o que cria a expectativa de o aluno empregar conhecimentos a respeito do parágrafo que ele talvez possua. Em consequência, sua produção de textos apresenta problemas de coesão e de estruturação, pois o aluno só tem condições de melhorar sua escrita se for exposto a um modelo de parágrafo a ser seguido, como ocorre no material didático de Língua Inglesa. A seguir tem-se o exemplo de como o parágrafo é abordado no material de Língua Portuguesa. 


\section{.e• Planejamento e elaboração do texto}

1. Planeje a entrevista de acordo com as seguintes etapas:

a) Convide uma pessoa para ser seu entrevistado. Explique-Ihe que você enviará as perguntas por carta ou e-mail e que elas deverão ser respondidas por escrito.

b) Faça uma pesquisa sobre a profissão do entrevistado. Consulte sites de universidades e guias de profissăo.

c) Elabore um roteiro de perguntas. Por exemplo: Quantos anos você tem? Possui algum hobby? Onde estudou? Por que escolheu essa profissão? 0 que já realizou? Quais são suas ambições? Como é sua rotina de trabalho?

d) Leve em conta, ao fazer o roteiro, o que o leitor de um Guia das Profissões quer saber: a rotina do profissional, o salário médio, as boas faculdades ou os cursos da área, a necessidade de formação complementar, a situação atual do mercado de trabalho, etc.

e) Extraia boas respostas de seu entrevistado, evitando fazer perguntas cujas respostas sejam apenas sim e não. Por exemplo, em vez de perguntar "O mercado de trabalho para médicos é bom?", pergunte "Como você avalia o mercado de trabalho para os médicos?".

f) Escreva sua carta ou e-mail com as perguntas e envie ou entregue ao entrevistado, pedindo-Ihe que responda ao questionário em dois ou três dias.

2. Redija o texto considerando os seguintes aspectos:

a) Verifique a necessidade de adaptar as respostas do entrevistado para que fiquem claras e de acordo com a norma-padrão da língua.

b) Dê ao texto um título que desperte o interesse do leitor.

c) Escreva um parágrafo introdutório com uma breve apresentação do entrevistado, um comentário sucinto sobre sua vida e suas realizações e um resumo dos assuntos a serem abordados na entrevista.

d) Se quiser, ilustre o texto com uma fotografia ou com um desenho de seu entrevistado.

Figura 8 - Livro didático "Para viver juntos", para o sexto ano, 2014, página 277.

Pode-se observar que, em meio a teorias relacionadas à argumentação, defesa de ponto de vista e do estudo de verbos que introduzem opinião, o aluno é solicitado a escrever um parágrafo introdutório a respeito do entrevistado, em que deverá descrevê-lo. Ou seja, se o professor apenas seguir as propostas de produção de texto do material em análise, o aluno somente trabalhará a opinião do outro, no caso em questão, de seu entrevistado, e não investirá em como expor seu próprio ponto de vista.

Com o enfoque proposto pelo material didático, o aluno do sexto ano terá pouco contato com o texto argumentativo, e menos ainda com a estrutura do parágrafo. Assim, fica clara a necessidade de o professor conhecer o livro com que trabalhará, para que possa seguir outro caminho em relação à produção de texto argumentativo e ao ensino da paragrafação. Essa escolha foi feita pela docente responsável pelo sexto ano da Escola Internacional; assim, sua metodologia de trabalho e seus resultados serão apresentados no Capítulo 3. 


\subsubsection{A coesão textual}

Assim como as noções de parágrafo trabalhadas anteriormente são importantes para ajustar o olhar sobre os dados desta pesquisa, a coesão textual também o é, inclusive por andar junto à paragrafação na estruturação do texto, na modalidade escrita ou na falada, independentemente de sua tipologia ou gênero. A coesão é um dos macrocritérios estabelecidos para análise do corpus, e, por isso, é importante delimitar, em linhas gerais, os conceitos que acerca da coesão textual que serão aplicados aos dados.

Os documentos relativos à educação abordados neste trabalho, que serão apresentados no Capítulo 2 (PCN e Guia do Participante - ENEM), têm a coesão entre seus fundamentos. Assim, evidencia-se a importância que essa tem na organização textual e, consequentemente, no ensino de língua portuguesa. Por isso é importante dedicar alguns momentos deste estudo para enfocá-la neste quadro teórico.

Os estudos sobre a coesão são fundamentais para a Linguística Textual, uma das linhas teóricas de olhar funcionalista sobre a linguagem, em oposição aos estudos de cunho estruturalista. Como referência de estudos sobre coesão, tem-se a obra Cohesion in English, de $1976^{26}$, de Halliday e Hasan, que passa a ser referência em investigações sobre o tema.

Os estudiosos defendem que o conceito de coesão está relacionado à semântica do discurso, já que as relações coesivas só existem dentro do texto e podem ser definidas apenas no texto. Nesse conceito, os elementos de um discurso, de uma comunicação, dependem um do outro para terem sentido, e também pressupõem um ao outro. Uma ilustração, na língua portuguesa, da coesão são os pronomes, que, para terem sentido, dependem de outro termo já expresso no discurso.

Halliday e Hasan (1976 [2013]) consideram que a coesão faz parte do sistema da língua. Segundo eles (1976 [2013]: 5) "the potential for cohesion lies in the systematic resources of reference, ellipsis and so on that are built into the language itself" ${ }^{\prime 27}$. Dessa forma, a coesão pode ser realizada pela gramática ou pelo léxico.

No Brasil, Ingedore Koch é um dos principais nomes relacionados aos estudos da coesão textual. Segundo a linguista (Koch, 2004: 35), coesão é a forma como os elementos linguísticos presentes na superfície textual se interligam, se interconectam por meio de recursos também

\footnotetext{
${ }^{26}$ A edição a que se teve acesso foi publicada em 2013.

27 “O potencial para as regras de coesão está, e é construído, nos recursos do próprio sistema linguístico, como em estruturas de referências, elipses, entre outras". Tradução nossa.
} 
linguísticos, de modo a formar um "tecido" (tessitura), uma unidade de nível superior à frase, que dela difere qualitativamente. Além disso, Koch (2007: 46) entende que a coesão "não está no texto, mas sim se constrói a partir dele numa situação interativa".

Os estudos sobre coesão indicam que há duas modalidades de coesão textual: coesão referencial e coesão sequencial. Conforme Koch (2007: 31), na primeira modalidade de coesão textual, "um componente da superfície do texto faz referência a outro(s) elemento(s) nela presente(s) ou inferível(is) a partir do universo textual". Vale mencionar também que, ainda segundo a autora, "o referente é algo que se (re)constrói textualmente". Já na segunda modalidade de coesão textual, estudam-se os procedimentos linguísticos por meio dos quais se estabelecem, entre segmentos do texto (enunciados, partes de enunciados, parágrafos e mesmo sequências textuais), diversos tipos de relações semânticas e (ou) pragmático-discursivas, à medida que se faz o texto progredir (Koch, 2004: 39).

Nesta pesquisa, delimitou-se o macrocritério Coesão, e nele serão investigados aspectos relacionados à coesão referencial e à coesão sequencial. Os microcritérios, organizados por tipo de coesão, seguem na tabela.

\begin{tabular}{|l|l|}
\hline \multicolumn{1}{|c|}{ Coesão referencial } & \multicolumn{1}{|c|}{ Coesão sequencial } \\
\hline Repetição de palavras & Uso de conectivos \\
\hline Colocação pronominal & Uso de tempos verbais \\
\hline $\begin{array}{l}\text { Uso de "coisa" como elemento de } \\
\text { retomada }\end{array}$ & Regência nominal e verbal \\
\hline $\begin{array}{l}\text { Uso de termos de referência sem } \\
\text { antecedente determinado. }\end{array}$ & \\
\hline
\end{tabular}

Tabela 1-Coesão referencial e coesão sequencial entre os critérios de análise dos dados.

Há ainda um microcritério de análise que pode contemplar elementos das duas modalidades de coesão, o "Truncamento de informações". Em geral, esse tipo de problema pode ocorrer não só por fatores ligados à coesão, já que está muito relacionada à sintaxe da língua. A questão é que, no desenho da pesquisa, o macrocritério mais adequado para abrigar incorreções dessa natureza é o da coesão, já que a questão sintática pode acarretar problemas coesivos, como o uso de um termo de referência que gerará ambiguidade sobre seu referente, ou a ausência de um complemento verbal. Em geral, em casos de truncamento estrutural, a coesão será prejudicada como consequência. 


\subsection{Prosódia}

Outro pilar teórico da presente pesquisa é a Fonologia Prosódica. Antes de apresentar os fundamentos dessa teoria, é interessante esclarecer o que se entende por prosódia. Câmara Júnior (2002 [1986]: 202), em seu Dicionário de Linguística e Gramática, apresenta uma definição objetiva do termo, mostrando sua caracterização para a gramática e sua relação com a fonética. O estudioso apresenta a prosódia como

parte da fonologia referente aos caracteres da emissão vogal que se acrescentam à articulação propriamente dita dos sons da fala, como em português o acento e a entonação. Os gramáticos gregos estudavam a prosódia para fins de métrica, e às vezes, ainda hoje, também assim se restringe a aplicação do termo. Outras vezes ele se usa como sinônimo de ortoépia.

Outra definição para o termo que merece ser mencionada é a de Crystal (2000: 213), em seu Dicionário de Linguística e Fonética. Ele apresenta o termo com maior riqueza de detalhes do que Câmara Júnior, ao apresentar também a visão da linguística, e as bases da Fonologia Prosódica. Para Crystal, prosódia é o

termo usado para indicar, de maneira coletiva, as variações de $\mathrm{PITCH}^{28}$, ALTURA, TEMPO E RITMO (grifos do autor). Às vezes, é usado como sinônimo de "suprassegmental", mas, em sentido mais restrito, se refere apenas às variáveis acima - os demais traços suprassegmentais são rotulados de PARALINGUÍSTICOS. Este segundo sentido se aproxima do uso tradicional do termo "prosódia", quando se refere às características e análises da estrutura de versos.

A teoria de fonologia proposta por J.R. Firth (fonologia prosódica) dá destaque especial à prosódia. Nessa abordagem, ela se opõe à UNIDADE FONEMÁTICA, ou seja, ela se opõe à UNIDADE FONEMÁTICA, ou seja, a uma unidade SEGMENTAL, como uma CONSOANTE ou uma VOGAL, nas quais as prosódias são traços que se estendem sobre contínuos de ENUNCIADO (pode-se falar de "prosódias de sentença" "prosódias de sílaba", etc.). Não apenas o pitch, o ACENTO e os padrões de JUNTURA estariam englobados na noção de prosódia, mas também traços como ARTICULAÇÕES SECUNDÁRIAS, tais como ARREDONDAMENTO dos lábios ou NASALIZAÇÃO, quando eles forem responsáveis pelas restrições fonotáticas ou então caracterizar a estrutura GRAMATICAL (grifos do autor).

Há também a definição proposta por Silva (2011: 188), em seu Dicionário de Fonética e Fonologia:

prosódia prosody ramo da linguística e da fonética que investiga as propriedades ou traços suprassegmentais da fala, os quais são percebidos como parâmetros de frequência fundamental, pitch, intensidade e duração. A prosódia tem estreita relação com o acento, ritmo e entonação.

\footnotetext{
${ }^{28}$ Aqui chamado de Inflexão Tonal, seguindo a tradução proposta por Madureira (1999).
} 
Assim, percebe-se que há uma convergência de definições entre Crystal e Silva, quando consideram a relação entre prosódia e os suprassegmentos e seus parâmetros, sendo consideradas definições mais adequadas de Prosódia para a investigação que se propõe realizar nessa pesquisa. Considera-se a definição de Crystal bastante esclarecedora e pertinente ao estudo, pois lança luz aos traços formadores dos sons da língua. $\mathrm{O}$ estudioso também deixa claro que os elementos de análise em relação à prosódia vão além do segmento, os quais não são contemplados nas investigações dos modelos lineares.

Complementando a noção de Prosódia, é preciso ter em mente alguns conceitos que Bisol (2010) traz no oitavo capítulo de seu livro. Ela recorda a noção de constituinte, que é "uma unidade linguística complexa, formada por dois ou mais membros que estabelecem entre si uma relação dominante/dominado". A autora também defende que os constituintes prosódicos não têm que estabelecer uma relação formal com os constituintes das outras áreas da gramática (sintaxe, morfologia, semântica e pragmática), como é o caso da palavra, na qual nem sempre há equivalência entre a palavra morfológica e a palavra fonológica.

A observação de Bisol (2010) acerca da não obrigatoriedade de equivalência prosódica e gramatical, aqui sob o olhar da sintaxe, mostra-se fundamental para o estudo em foco, pois os dados analisados indicam que não há obrigatoriedade de equivalência entre os limites sintáticos (orações e sentenças) e os limites prosódicos. Nos dados isso fica ainda mais evidente quando se aborda as questões de pontuação, que, na escrita, delimita constituintes sintáticos, questão que será apresentada e analisada mais adiante.

Ponto pacífico entre os estudiosos da área é que os sons de uma língua são formados por traços analisáveis, definidos, anteriormente, na proposição de Crystal. Um dos focos deste trabalho é a inflexão tonal (pitch), como ela age na coesão do texto oral e em sua transposição para o texto escrito. Dessa forma, é importante considerar o que ensina Mateus (2004: 6), quando descreve esse traço:

O tom (ou pitch) tem como correlato acústico a frequência da onda sonora, ou seja, o número de vezes que um ciclo completo de vibração das partículas se repete durante um segundo. Quanto maior o número de ciclos de vibração das partículas, maior e a altura do som e, portanto, mais "alto" e o tom. A frequência fundamental relaciona-se de um ponto de vista articulatório, com as cordas vocais: quanto mais delgadas, maior numero de vibrações, maior altura do som.

Uma sequência de segmentos com os respectivos tons cria a entoação dessa sequência, quer se trate de uma palavra ou de um grupo de palavras. 
Assim, é possível observar que os traços prosódicos são importantes para o funcionamento das línguas, tendo em vista que a eles cabem distinguir significados (como mostra Moraes 2008 e Santos 2009), além de desfazer ambiguidades sintaticamente motivadas (cf. Fonseca 2012), transmitir informações sobre o estado emocional do falante ( $c f$. Colamarco 2009), manter ou passar o turno da conversa, alinhavar as informações do texto oral, entre outras possibilidades (os estudos aqui referidos serão apresentados adiante). Dessa forma, percebe-se o quão importante é debruçar-se sobre os elementos prosódicos da comunicação, área que vem crescendo nos últimos anos, mas que muito ainda tem a ser investigado.

Vale reforçar que entonação é um dos pontos de interesse deste estudo, pois acredita-se que é, também, por meio dela que os elementos discursivos e sintáticos, no texto oral, se processam, principalmente as marcas equivalentes ao que representa a pontuação em um texto escrito. Francis Nolan $(2006)^{29}$, em seu texto intitulado "Intonation", relaciona a entonação ao significado da fala, independentemente das palavras que a compõem e sua representação sonora. Assim, a entonação faz parte do sentido global do enunciado e, segundo o autor, possui tanta relevância quanto a sua formação estrutural, de cunho sintático. A entonação é modulada pelo pitch, que vai além da sentença, e não pode ser considerada isoladamente, possui outros elementos que a compõem, como "timing, loudness and sound voice" (tempo, intensidade e som da voz).

Madureira (1999: 55) afirma que a entonação "compreende padrões de pitch que têm forma, função e domínios específicos". Para pitch a autora propõe como tradução o termo 'inflexão tonal', que será utilizado aqui, a partir de agora. Ela afirma, também, que as alterações na fala chamadas de entonação correspondem: a modulações de frequência fundamental, que é medida em hertz; à intensidade, medida em decibéis; e à duração, medida em milissegundos. Sobre a frequência fundamental (F0), Madureira (1999: 55) afirma que

\begin{abstract}
o parâmetro acústico mais importante da entoação é a frequência fundamental, termo que designa o número de repetições de ciclos de uma onda periódica. O correlato fisiológico da frequência fundamental é o número de vibrações (o abrir e fechar) das cordas vocais e o correlato perceptual é o pitch (inflexão tonal).
\end{abstract}

Nolan (2006.: 1), em seu estudo, diferencia entonação de prosódia. Para ele, entonação está relacionada aos efeitos da inflexão tonal na fala, e prosódia atribui um caráter mais

\footnotetext{
${ }^{29}$ Cf. F. Nolan (2006) Intonation. In: B. Aarts \& A. McMahon (eds), Handbook of English Linguistics. Oxford: Blackwell. Pre-publication version: Intonation.

Disponível em: http://www.ling.cam.ac.uk/francis/FN_inton_prepub.pdf acesso em 22 de janeiro de 2013.
} 
generalizante, que agrega características como "patterns of pitch, timing, loudness and (sometimes) voice quality ${ }^{30}$ ". O autor ainda defende que a entonação carrega uma variedade de tipos de informação, possui uma função dentro do discurso, pode refletir a estrutura da informação de uma sentença e destacar constituintes importantes dentro do enunciado.

O estudioso entende que utilizar o termo Fonologia para se referir à Entonação implica entender que eles são discretos. Dessa forma, possuem unidades linguísticas contrastivas, que formam a base contínua da variável melódica da fala, e essas unidades não são providas de significado, embora passem a tê-lo quando inseridos em um contexto, combinados com outros elementos.

Ressalta-se que a entonação ainda pode transmitir atitudes do falante, como amizade, entusiasmo e hostilidade. Outra característica da entonação é funcionar como uma pista paralinguística a respeito do estado emocional do falante - como excitação, depressão e tristeza -, além de poder regular a alternância de turnos em uma conversa, situação de interação comunicativa, o que a torna importante também para os estudos acerca da polidez. Essas funções da entonação vêm sendo estudadas, no Brasil, por pesquisadores da Universidade Federal de Minas Gerais (grupo de pesquisa do professor doutor César Reis) e Universidade Federal do Rio de Janeiro ( $c f$. Moraes 2008). Esses estudos têm corroborado a relevância da entonação nas línguas naturais.

\subsubsection{Fonologia Prosódica}

Com a entonação e seus constituintes chamando a atenção dos estudiosos, desenvolveuse a Fonologia Prosódica. Nas palavras de Mateus (2004: 7), essa enfocaria a forma como “o fluxo da fala é organizado num conjunto finito de unidades fonológicas. A Fonologia Prosódica é, também, uma teoria das interações, ou seja, das relações de interface entre a fonologia e os outros componentes da gramática, mediadas pela prosódia”.

A organização mental da fala dividida em fragmentos hierarquicamente organizados é um ponto fundamental para a teoria prosódica. Os estudiosos que se debruçam sobre ela trabalham com níveis específicos, que possuem características próprias, e se realizam no fluxo natural da fala. Segundo Nespor \& Vogel (1986:13), pesquisadoras tidas como referência nos

\footnotetext{
${ }^{30}$ Padrões de PITCH, tempo, altura (do som) e (em alguns casos) qualidade de voz.
} 
estudos da prosódia, os constituintes prosódicos da gramática estão marcados com diferentes classes de sinais que abarcam desde modificadores segmentais em si, até mudanças fonéticas mais sutis. É importante ressaltar também que, segundo as autoras, cada constituinte prosódico atua como domínio de aplicação de regras fonológicas específicas e de processos fonológicos.

O trabalho de Nespor \& Vogel (1986) delimita alguns pontos teóricos acerca dos estudos prosódicos. Um dos principais é a organização prosódica em sete níveis hierárquicos de constituintes que as autoras definem: sílaba $(\sigma)$, pé $(\Sigma)$, palavra fonológica $(\omega)$, grupo clítico $(C)$, frase fonológica $(\phi)$, frase entonacional (I) e enunciado (U). Cada um dos níveis definidos possui características próprias, além de conter em si o nível anterior.

Nem todos os estudiosos que se dedicaram à prosódia utilizam em seus estudos a hierarquia de constituintes prosódicos proposta por Nespor \& Vogel. Em sua tese de doutorado, ao abordar a Fonologia Prosódica, Pacheco (2006: 56) utiliza o quadro proposto por Shattuck Hufnagel \& Turk (1996), o qual compara as propostas, e seus autores, para os níveis de constituintes prosódicos. Para se ter uma visão geral das teorias, considera-se pertinente reproduzir o quadro.

Essa representação mostra a similaridade entre as propostas de Nespor \& Vogel com a de Hayes, em que os domínios prosódicos são os mesmos, ou seja, os apresentados na imagem abaixo:

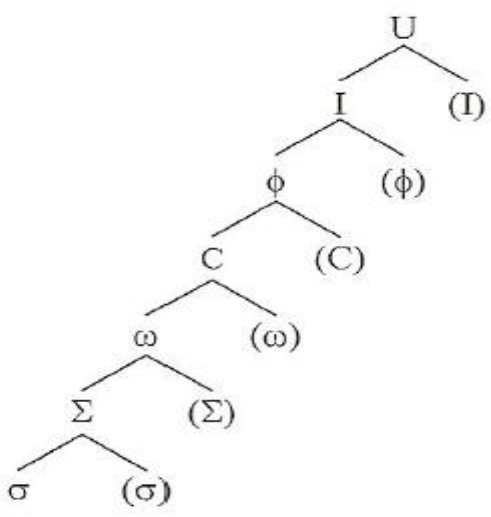

\author{
enunciado \\ frase entonacional \\ frase fonológica \\ grupo clítico \\ palavra fonológica \\ pé \\ sílaba
}

Figura 9 - Hierarquia Prosódica segundo Nespor \& Vogel, 1986.

Observa-se que o nível mais baixo na hierarquia é a sílaba e o mais alto é o enunciado. Selkirk apresenta domínios nomeados de forma diferente, em que não há equivalente ao grupo clítico. Conforme a Figura 10, Beckmam \& Pierrehumbert apresentam a proposta mais peculiar 
dentre as elencadas, em que há apenas três domínios prosódicos, iniciando-se pela Frase Acentual - equivalente à Frase Menor de Selkirk e sem correspondente na proposta de Hayes e Nespor \& Vogel - e se encerra na Frase Entonacional Completa, equivalente à Frase Entonacional das outras duas propostas.

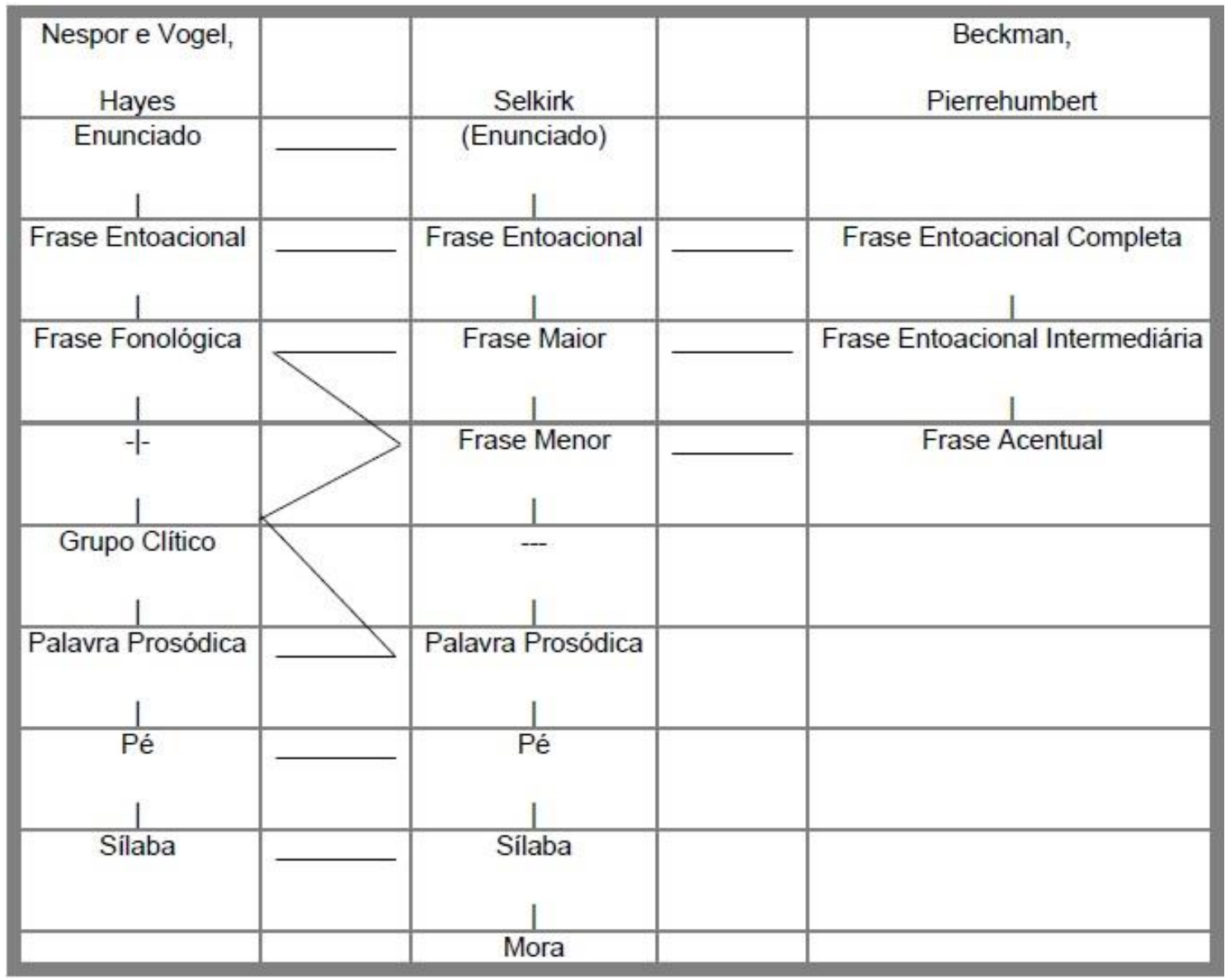

Figura 10 - Comparação de hierarquia de constituintes prosódicos. Pacheco, 2006: 56

Nesta pesquisa, será privilegiada a visão de Nespor \& Vogel por se considerar o modelo mais pertinente à análise que se pretende fazer. Contudo, é importante reconhecer a relevância dos modelos propostos para o estudo da Prosódia. Em razão disso, a próxima subseção tratará especificamente do modelo escolhido para ser privilegiado neste estudo. 


\subsection{1.a Nespor \& Vogel}

Marina Nespor e Irene Vogel se debruçaram sobre o estudo da fonologia prosódica, com base em dados da língua italiana. Para elas, a representação mental da fala está dividida em fragmentos hierarquicamente organizados, os quais, no fluxo natural da fala, estão marcados com diferentes classes de sinais que incluem desde modificações segmentais em si, até mudanças fonéticas mais sutis (Nespor \& Vogel, 1994: 13). Cada um dos níveis hierárquicos constitui um domínio prosódico, com características próprias e com diferentes tipos de informação fonológica. E cada domínio possui como característica as especificidades do domínio anterior somada às suas peculiaridades; sendo assim, a palavra fonológica $(\omega)$ possui suas características além das do pé $\left(\sum\right)$, e assim por diante. Então, matematicamente pensando: $(\omega)=\left(\sum\right)+1$

As estudiosas destacam que não há uma similaridade completa entre os domínios prosódicos e elementos da morfologia e da sintaxe, apesar de refletirem alguma noção desses níveis de análise da língua. Dessa forma, a prosódia serviria, como já mencionado neste capítulo da pesquisa, também para desfazer questões em que a sintaxe provoca ambiguidade, como no exemplo:

\section{Maria abraçou sua irmã molhada.}

Figura $11-$ Exemplo 02

Observa-se que, na frase, há uma ambiguidade de cunho sintático, pois não se sabe se quem estava molhada era Maria ou sua irmã. Para as autoras, a prosódia poderia resolver a questão, a depender do elemento mais proeminente, entre outros elementos prosódicos. Frases com essa natureza têm sido alvo de estudiosos, como se verá no capítulo seguinte com o estudo de Fonseca (2012).

Quanto à morfossintaxe, Nespor \& Vogel defendem que seus níveis hierárquicos são divergentes dos da prosódia, uma vez que a estrutura fonológica é finita, e a sintática, infinita (Nespor \& Vogel, 1994: 14). Os dados dos estudos das autoras embasam e confirmam essa afirmativa, e as análises feitas com a língua portuguesa nesta pesquisa corroboram-na, mais uma vez. 
Nespor \& Vogel também relacionam os componentes fonológicos com os semânticos, e afirmam que essa relação é necessária devido a algumas informações semânticas que são acessadas via componentes fonológicos, sobretudo nos níveis mais altos da hierarquia prosódica. Apesar de não ser abordada pelas autoras, não se pode deixar de se considerar a relação entre prosódia e Pragmática, como já foi mencionado neste trabalho. Algumas informações de cunho pragmático só são possíveis de serem acessadas via prosódia, também em níveis hierárquicos mais altos, como é o caso da ironia. Assim, cogita-se a hipótese de haver domínios prosódicos em níveis maiores do que os identificados pelas estudiosas, mas isso deverá ser verificado nos dados, que serão coletados na próxima fase desta pesquisa, como será esclarecido no capítulo metodológico.

Como cerne da teoria da Fonologia Prosódica, tem-se os domínios prosódicos, que são os seguintes:

- sílaba $(\sigma)$-é considerada a menor categoria prosódica, e tem como cabeça sempre uma vogal, que é o elemento de maior sonoridade, acompanhada de consoantes e/ou glides, que segundo Bisol (2006), são seus dominados. Ela é uma unidade fonológica e, portanto, prosódica, sendo a base da hierarquia prosódica;

- pé $\left(\sum\right)$-é a combinação de duas ou mais sílabas, em que há uma relação de dominância de uma com a outra, e é responsável por regras fonológicas no português como a do acento;

- palavra fonológica $(\omega)$ - é o domínio em que se realiza a interação entre a fonologia e a morfologia, é composta por pés (lembrando que um domínio possui as características do nível anterior, somado às suas peculiaridades), possui apenas um acento primário, e não necessariamente corresponde à forma morfológica da palavra;

- grupo clítico (C) - o clítico, no português, são palavras (geralmente pronomes e artigos) átonas - o, a, te, se, me, etc. - que em geral se unem à palavra de conteúdo no fluxo de fala espontâneo ([[me] $\omega$ [leve]C]), e é nesse nível em que começam a ocorrer o fenômeno do sândi externo (por hora $=$ porora $\rightarrow$ grupo $C$ ). Esse é um fenômeno muito importante na análise dos dados desta pesquisa, que será investigado e discutido nos capítulos seguintes. Sobre o grupo clítico e sua importância para o fenômeno de sândi, e sobre como o clítico perde totalmente sua independência em C, Bisol (2006: 266) afirma: 
Quando o sândi ocorre entre dois elementos de um grupo clítico, a reestruturação silábica os converte em uma só palavra fonológica. É neste caso que o clítico perde totalmente sua independência para tornar-se, com a palavra de conteúdo adjacente, uma unidade só. Na escala prosódica, o grupo clítico é, pois, o domínio mais baixo na aplicação do sândi externo. Somente por ação desse, o clítico incorpora-se totalmente à palavra de conteúdo adjacente.

- frase fonológica $(\phi)$ - é outro domínio que terá destaque nesta pesquisa. A frase fonológica é constituída de um ou mais Cs, em que há um elemento proeminente e com cabeça lexical. Nesse domínio também se observam sândis externos, o que também tem sido confirmado no estudo piloto, assim como a não obrigatoriedade de isomorfismo entre $\phi$ e a sintaxe;

- frase entonacional (I) - formada por um conjunto de $\phi s$, sendo domínio de um contorno de entonação, com seus fins marcados por pausas. Eis mais um nível que os dados tentarão investigar, quanto ao efeito discursivo na argumentação, sobretudo no que diz respeito às pausas; $\mathrm{e}$

- enunciado $(\mathrm{U})$ - é o mais alto nível da hierarquia prosódica - afirmação que também se busca confirmar nos dados deste estudo - é formado por uma ou mais frases entonacionais. Seu limite é marcado por pausa, assim como I, e onde se dá o efeito pragmático e discursivo do texto. Também nesse nível não é obrigatório o isomorfismo entre fonologia e sintaxe.

Como já mencionado, os níveis hierárquicos propostos por Nespor \& Vogel são fundamentais para a presente pesquisa, pois a prosódia será investigada com ênfase nos níveis mais altos da hierarquia prosódica. Isso por causa do objetivo de investigar os efeitos textuais, discursivos e pragmáticos desse elemento fundamental da língua portuguesa. 


\title{
Capítulo 2 - Questões sobre ensino
}

\begin{abstract}
Quando se fala em "usar melhor" [a língua portuguesa], pode-se pensar em ser capaz de usar a chamada norma culta padrão, mas também se pode pensar em eficácia comunicativa. $\mathrm{O}$ ensino de língua deveria centrar-se menos em exercícios gramaticais, de ensino da metalinguagem, e mais em possibilitar ao aluno o domínio das várias modalidades de uso e da modalidade culta da comunidade de que ele faz parte. CALLOU, 2009:28.
\end{abstract}

Como e para que se ensinar língua portuguesa na escola? Essa é uma pergunta que há anos faz parte da vida de muitos alunos e professores. Muitas são as respostas possíveis: porque é importante, porque você vai precisar desses conhecimentos no vestibular, porque você precisa tirar notas boas para passar de ano, entre tantas outras. Aqui também não se pretende respondêla, mas sim problematizar, mais um pouco, em torno dessa temática.

A escola é vista, pelos alunos, como fonte de novos conhecimentos, lugar em que eles vão para aprender novas informações, e se eles já sabem falar português, não faz sentido dedicar tanto esforço na aprendizagem de algo que eles já sabem. O fundamental, nesse ponto, é deixar claro para o aluno que o foco do ensino da língua portuguesa não é o conhecimento que ele já detém, ou seja, a fala do cotidiano, mas sim a língua padrão, com grande ênfase para a escrita.

Possenti (1996: 13) defende que "o objetivo da escola é ensinar o português padrão, ou, talvez mais exatamente, o de criar condições para que ele seja aprendido". Assim, o foco do ensino de língua portuguesa como língua materna seria propiciar ao aluno condições de aprender uma nova modalidade e variedade da língua portuguesa, provavelmente, diferente do que ele usa ao se comunicar oralmente. E assim nota-se que um dos pontos importantes do ensino de língua portuguesa está na diferença entre língua falada e língua escrita. Além disso, é importante que o alunado perceba quão segregador pode ser o desconhecimento desse dito português padrão.

Travaglia, em seu livro de 2004, entende que vale a pena ensinar gramática nas escolas se essa proporcionar ao aluno condições de melhorar o seu papel social. O linguista faz parte do grupo de estudiosos que pensam o ensino de língua materna voltado para a interação, deixando de lado o enfoque sobre o ensino meramente metalinguístico. Essa visão é também a defendida por Callou na epígrafe deste capítulo, que traz mais uma voz em defesa de um ensino que promova mudança na relação do aluno com o mundo, e essa é uma das ideias que permeia todo o trabalho desenvolvido nesta tese.

A questão do ensino de língua portuguesa será enfocada nas páginas a seguir, nas quais se deixará claro o posicionamento assumido neste estudo acerca das questões voltadas ao ensino 
de língua materna. Neste capítulo, será feita uma breve explanação sobre os PCN e uma apresentação das BNCC, documentos do governo brasileiro que subsidiam o ensino de Língua Portuguesa. Além desse olhar sobre a base do ensino, serão enfocadas questões pertinentes à análise de dados, mas que se relacionam intimamente com o ensino, como a pontuação e as matrizes de correção de textos e questões discursivas que nortearam os critérios de análise aqui adotados. Por fim, algumas questões relativas à análise de erros serão apresentadas.

\subsection{Parâmetros Curriculares Nacionais - alguns princípios norteadores do ensino de língua portuguesa.}

A discussão sobre o ensino de língua portuguesa não é recente, prova disso é a proposta dos Parâmetros Curriculares Nacionais (PCN), que datam de 1998. O ensino de língua portuguesa no Brasil é regulamentando PCN, assim como todo o ensino brasileiro. Eles regem o ensino na Escola Internacional, relativo ao currículo brasileiro, apesar de a instituição incentivar uma abordagem em que se mescle, com adaptações, PCN e Commom Core $^{31}$ - que seria, grosso modo, os PCN propostos para a educação nos Estados Unidos, ou melhor, a BNCC americana.

Já na introdução do documento, fica evidente a preocupação com o ensino de língua portuguesa, pela dificuldade de se alfabetizar os alunos e de formar cidadãos verdadeiramente proficientes em sua língua materna, sobretudo na língua escrita. Na busca do caminho para a formação de bons leitores e eficientes produtores de textos escritos, a educação brasileira vem tentando encontrar um caminho de sucesso, e a implementação dos PCN de língua portuguesa é uma dessas tentativas.

Sua base teórica vai além da abordagem clássica do ensino de língua materna centrado em uma abordagem prescritiva, no qual se prioriza a gramática normativa. No documento, a linguagem é compreendida como meio de comunicação, de acesso à informação, de construção

\footnotetext{
${ }^{31}$ São objetivos de aprendizagem que direcionam o ensino de Matemática e Língua Inglesa nos Estados Unidos. Segundo página oficial, The Common Core is a set of high-quality academic standards in mathematics and English language arts/literacy (ELA). These learning goals outline what a student should know and be able to do at the end of each grade. The standards were created to ensure that all students graduate from high school with the skills and knowledge necessary to succeed in college, career, and life, regardless of where they live. Forty-two states, the District of Columbia, four territories, and the Department of Defense Education Activity (DoDEA) have voluntarily adopted and are moving forward with the Common Core. Disponível em http://www.corestandards.org/about-the-standards/. Acesso em 30 de agosto de 2015.
} 
de argumentos e de cultura. Já a língua é tida como um "sistema simbólico utilizado por uma comunidade linguística”. Os dois conceitos estão voltados para o mesmo caminho, que é a interação social e a forma de se relacionar com o mundo, pois isso se dá por meio da linguagem.

Um ensino que tem como base os conceitos de linguagem e de língua apresentados não está interessado apenas em ensinar as regras gramaticais e como se analisar a língua, mas sim está preocupado em formar cidadãos que saibam utilizar a linguagem no exercício de sua cidadania. Com isso, à escola cabe instrumentalizar os alunos para esse fim e formar cidadãos críticos e reflexivos, dando-lhes um ensino significativo e de qualidade, sobretudo no que diz respeito à disciplina Língua Portuguesa.

Os PCN consideram também que interagir pela linguagem é produzir discursos, pois é na comunicação que o uso da língua acontece, pressupostos também enfocados na base teórica desta pesquisa. Essa compreensão de língua e linguagem implica consequências sérias ao ensino de língua materna, pois o alvo não é mais a estrutura, e sim o contexto de uso, no qual as condições de produção de um texto, os interlocutores e o objetivo da comunicação têm tanta importância quanto à correção gramatical.

Uma das consequências para o ensino, gerada pela noção de língua adotada é a mudança na percepção de texto, já que a Teoria dos Gêneros Textuais propõe um ensino de redação diferente da noção tradicional na qual o aluno escreve um texto dissertativo sem um leitor real, e sem uma função social também real. Esse é um pequeno ponto das inovações propostas pelos PCN, em 1998, que demonstra a dificuldade de se perceber a linguagem sob a perspectiva do uso, com um viés interacional, tendo em vista que o encontrado em materiais didáticos e em salas de aula de língua portuguesa, ainda hoje, em 2015, não está alinhado, completamente, ao que propõe o documento.

Um ponto enfatizado pelos PCN e que ainda precisa ser aprimorado em materiais didáticos e práticas pedagógicas, ao menos entre o público enfocado nesta pesquisa, é o trabalho sistematizado com o texto oral. O documento propõe que os alunos analisem textos nessa modalidade para que percebam suas características, variações, funções sociais, estruturação e diferença entre essa e a modalidade escrita da língua. O quadro a seguir, retirado da página 49 do documento, indica o que se espera de um aluno em relação ao processo de escuta de textos orais. Assim é esperado que o aluno 
- amplie, progressivamente, o conjunto de conhecimentos discursivos, semânticos e gramaticais envolvidos na construção dos sentidos do texto;

- reconheça a contribuição complementar dos elementos nãoverbais (gestos, expressões faciais, postura corporal);

- utilize a linguagem escrita, quando for necessário, como apoio para registro, documentação e análise;

- amplie a capacidade de reconhecer as intenções do enunciador, sendo capaz de aderir a ou recusar as posições ideológicas sustentadas em seu discurso.

Figura 12 - Brasil, 1998:49. O que se espera do aluno no processo de escuta de textos orais.

O documento defende um ensino de língua em que a gramática não seja apenas centrada na metalinguagem, com foco nos manuais prescritivos, como já foi mencionado, descontextualizada e sem sentido prático para a vida real do aluno. Nesse sentido, na página 29 dos PCN, tem-se que

O que deve ser ensinado não responde às imposições de organização clássica de conteúdos na gramática escolar, mas aos aspectos que precisam ser tematizados em função das necessidades apresentadas pelos alunos nas atividades de produção, leitura e escuta de textos.

Um dos princípios teóricos básicos sobre o ensino dos conteúdos de língua portuguesa que subsidiam as propostas dos PCN é o eixo Uso $\rightarrow$ Reflexão $\rightarrow$ Uso. Assim, todo o ensino seria pensado a partir do uso e para o uso da língua. Esse fundamento teórico se alinha à base epistemológica desta pesquisa, a $U B L$. Dessa forma, não há como praticar o ensino gramatical, mas, sim, realizar a análise linguística do português.

Segundo os PCN, a prática da análise linguística é fundamental em sala de aula, e não representa um novo nome para a mesma análise gramatical da língua. Ao contrário, propõemse, nessa análise, o olhar a língua e sua estrutura, considerando-se o discurso na qual ela está sendo usada. Dessa forma, como já foi trabalhado no capítulo anterior, o texto seria o objeto de análise e a estrutura linguística seria ensinada com base no gênero textual, considerando-se os aspectos estruturais, pragmáticos e discursivos, conjuntamente. Isso significa trabalhar classes de palavras, mas não fazer o aluno decorar todos os substantivos epicenos e sobrecomuns, mas verificar como esses elementos estruturais são usados para a comunicação oral e escrita, formal e informal, sempre relacionando a estrutura linguística à língua em uso, ou seja, ao discurso.

O foco desta pesquisa é a produção textual, e sobre essa os PCN têm uma seção na qual se define o que se espera de um aluno nessa prática. Produzir um texto, como o próprio 
documento defende, é uma tarefa complexa, em que se tem que coordenar várias ações, tais como: o que se vai informar, para quem, como, com qual linguagem e com qual registro. No sexto ano essa sincronia de ações é muito complexa, exigindo um professor que saiba guiar o aluno pelo fazer textual, definindo um percurso a ser seguido que pode passar pela paráfrase, por reescrever o que outro texto informa, por analisar seu texto e refazê-lo com o auxílio docente, entre outras ações construtoras de um bom texto escrito.

Os PCN propõem que a seleção dos conteúdos a serem trabalhados seja feita com base na capacidade e nas necessidades do aluno, e não no que a tradição escolar predetermina. Contudo, teoria e prática não se encontram na prática escolar, ainda hoje. O ensino continua organizado com base no que a tradição define, além das necessidades que a realidade social impõe como o clássico ensino voltado para o vestibular, ou, como pode ser observado em uma rede privada de ensino do Distrito Federal, a seleção de conteúdos com vistas a preparar os alunos para concursos públicos.

Em relação ao ensino de língua portuguesa, os PCN trazem propostas que redistribuem os papéis no contexto escolar e posicionam o aprendiz no centro da questão. Dessa forma, escola e professores devem planejar a organização e a sequenciação dos conteúdos conforme a figura seguinte apresenta. Nota-se a valorização do grau de autonomia do sujeito, o que propicia à escola seguir nessa direção.

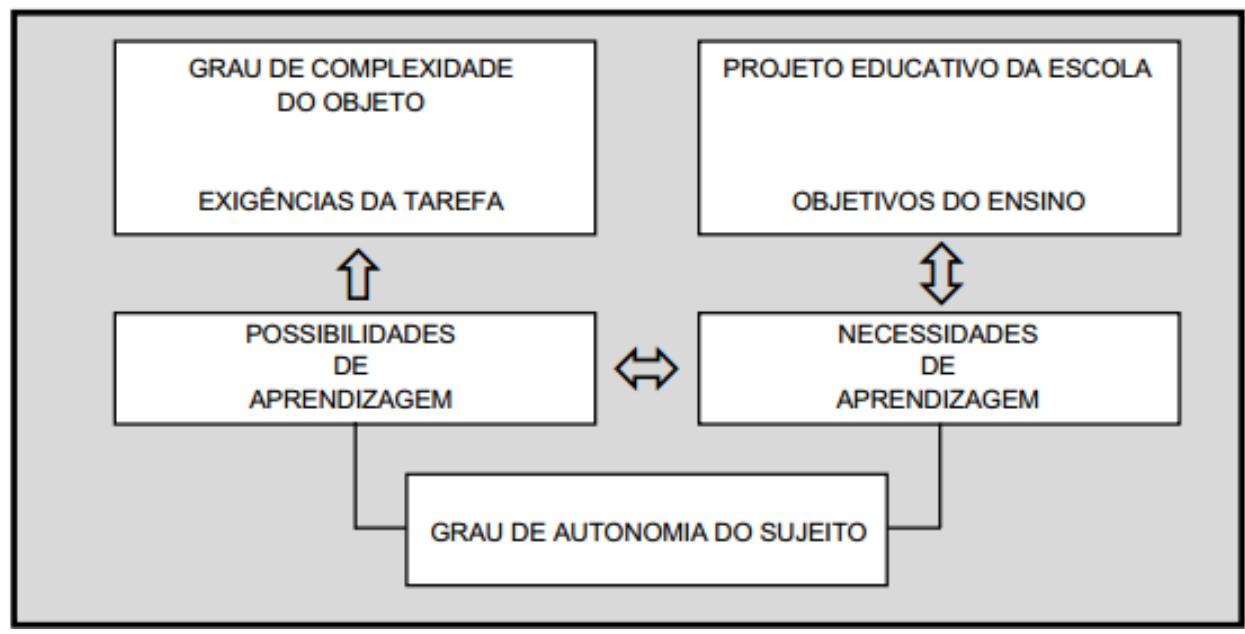

Figura $13-\mathrm{PCN}$ página 39

$\mathrm{O}$ ensino proposto pelos PCN em relação ao ensino de língua portuguesa demanda profissionais da educação, em todas as esferas, engajados à prática proposta. Só que esse engajamento passa por algumas questões prévias, como um professor capacitado para a prática da análise linguística, para o incentivo à leitura, com condições de ser também um pesquisador 
em sua sala de aula, para, constantemente, monitorar o desenvolvimento e as necessidades de seus aprendizes, para organizar projetos integradores e motivadores, além de proporcionar uma gestão que apoie as iniciativas e propostas feitas por seus docentes.

\subsection{Base Nacional Comum Curricular}

O governo federal do Brasil lançou, em setembro de 2015, uma nova e inicial proposta de ensino para o país que pretende determinar os conteúdos mínimos que os brasileiros precisam ter em sua formação, da Educação Infantil até o Ensino Médio. Trata-se de um documento preliminar à Base Nacional Comum Curricular (doravante BNCC), no qual se expõem a proposta em si, com princípios, forma de organização e conteúdo. Esse documento ficará disponível para consulta pública ${ }^{32}$, e a proposta é que, após ampla discussão, ele seja adaptado e efetivamente publicado em junho de 2016. Vale lembrar que a elaboração de um currículo comum a todas as escolas do país está prevista desde a Constituição de 1988, e apenas em 2015 começa a sair do campo das ideias.

A Base Nacional Curricular Comum tem como objetivo garantir aos cidadãos brasileiros o direito à educação com uma qualidade mínima e comum a todos, independentemente da localização geográfica e de rede de ensino (pública ou privada). Assim, o documento, na exposição de seus princípios, apresenta treze direitos, expostos a seguir, garantidos aos alunos na Educação Básica.

\footnotetext{
${ }^{32} \mathrm{O}$ documento está disponível em http://basenacionalcomum.mec.gov.br/, página em que se pode, também, opinar sobre a proposta.
} 
- desenvolver, aperfeiçoar, reconhecer e valorizar suas próprias qualidades, prezar e cultivar o convívio afetivo e social, fazer-se respeitar e promover o respeito ao outro, para que sejam apreciados sem discriminação por etnia, origem, idade, gênero, condição física ou social, convicções ou credos;

- participar e se aprazer em entretenimentos de caráter social, afetivo, desportivo e cultural, estabelecer amizades, preparar e saborear conjuntamente refeições, cultivar o gosto por partilhar sentimentos e emoções, debater ideias e apreciar o humor;

- cuidar e se responsabilizar pela saúde e bem estar próprios e daqueles com quem convive, assim como promover o cuidado com os ambientes naturais e os de vivência social e profissional, demandando condições dignas de vida e de trabalho para todos;

Figura 14 - Base Nacional Curricular Comum - página 8.

- se expressar e interagir a partir das linguagens do corpo, da fala, escrita, das artes, da matemática, das ciências humanas e da natureza, assim como informar e se informar por meio dos vários recursos de comunicaçōo e informação:

- situar sua familia, comunidade e nação relativamente a eventos históricos recentes e passados, localizar seus espaços de vida e de origem, em escala local, regional, continental e global, assim como cotejar as características económicas e culturais regionais e brosileiras com as do conjunto das demais nações;

Figura 15 - Base Nacional Curricular Comum - página 8. 
- experimentar vivências, individuais e coletivas, em práticas corporais e intelectuais nas artes, em letras, em ciências humanas, em ciências da natureza e em matemática, em situações significativas que promovam a descoberta de preferências e interesses, o questionamento livre, estimulando formação e encantamento pela cultura.

- desenvolver critérios práticos, éticos e estéticos para mobilizar conhecimentos e se posicionar diante de questöes e situaçōes problemáticas de diferentes naturezas, ou para buscar orientação ao diagnosticar, intervir ou encaminhar o enfrentamento de questões de caráter técnico, social ou econômico;

- relacionar conceitos e procedimentos da cultura escolar àqueles do seu contexto cultural; articular conhecimentos formais às condições de seu meio e se basear nesses conhecimentos para a condução da própria vida, nos planos social, cultural, e econômico;

- debater e desenvolver ideias sobre a constituiçăo e evoluçăo da vida, da Terra e do Universo, sobre a transformaçāo nas formas de interaçāo entre humanos e com o meio natural, nas diferentes organizações sociais e politicas, passadas e atuais, assim como problematizar o sentido da vida humana e elaborar hipóteses sobre o futuro da natureza e da sociedade;

- experimentar e desenvolver habilidades de trabalho; se informar sobre condições de acesso à formação profissional e acadêmica, sobre oportunidades de engajamento na produção e oferta de bens e serviços, para programar prosseguimento de estudos ou ingresso ao mundo do trabalho;

- identificar suas potencialidades, possibilidades, perspectivas e preferências, reconhecendo e buscando superar limitações próprias e de seu contexto, para dar realidade a sua vocação na elaboração e consecuçăo de seu projeto de vida pessoal e comunitária;

- participar ativamente da vida social, cultural e política, de forma solidária, crítica e propositiva, reconhecendo direitos e deveres, identificando e combatendo injustiças, e se dispondo a enfrentar ou mediar eticamente conflitos de interesse.

Figura 16 - Base Nacional Curricular Comum - página 9.

O documento reconhece que a escola não é a única instituição responsável por garantir esses direitos aos cidadãos, mas, como se sabe, a cada dia seu papel social é redimensionado, essa instituição ganha novas atribuições no desenvolvimento do indivíduo. Os direitos apresentados devem ser trabalhados durante todo o percurso escolar, envolvendo-se todas as áreas de conhecimento, e deve acontecer "de forma articulada e progressiva" (Brasil, 2015: 10). 
Fica claro que a BNCC não é o todo do currículo que as escolas devem seguir, é, como o próprio nome sugere, uma base. A ela, as escolas acrescentaram conhecimentos decorrentes de questões culturais e das necessidades específicas de cada rede e localidade. A BNCC está organizada em quatro eixos introdutórios: Linguagens, Matemática, Ciências da Natureza e Ciências Humanas. A Língua Portuguesa fica dentro do eixo Linguagens, juntamente com Língua Estrangeira Moderna, Arte e Educação Física. Essa área busca desenvolver a comunicação e a expressão por meio de diversas linguagens, com criação e reprodução de ideias. No Ensino Fundamental, segmento no qual se insere o sexto ano, os objetivos para a área de linguagem seguem apresentados pelas figuras a seguir.

- dominar, progressivamente, a fala, a leitura e a escrita;

- viver, refletir sobre a se apropriar dos elementos constitutivos das diferentes linguagens artísticas;

- vivenciar, refletir sobre, apropriar-se de, criar e recriar as práticas corporais;

- reconhecer e valorizar a a pluralidade de manifestações culturais (linguística, artística e corporal);

- reconhecer e compreender o uso de outra(s) língua(s), assim como valorizar a(s) diversa(s) cultura(s);

- respeitar características individuais e sociais, as diferenças de etnia, de classe social, de crenças, de gênero manifestadas por meio das linguagens, assim como a valorização da pluralidade sociocultural brasileira e de outros povos e nações;

- propiciar àqueles/às que apresentem necessidades diferenciadas de comunicação aos conteúdos, o acesso à utilização de linguagens e códigos aplicáveis e de tecnologia assistiva;

Figura 17 - Base Nacional Curricular Comum - página 35. 
- aproximar-se das diversas tecnologias, permitindo não apenas sua utilização como instrumentos de comunicação e informação, mas também o entendimento crítico das relações entre sociedade e tecnologia e o intercâmbio cultural.

Figura 18 - Base Nacional Curricular Comum - página 35.

O conceito de linguagem que dá suporte para a BNCC tem como premissa a interação, e está alinhado ao que defendem os PCN e a principal linha teórica desta pesquisa, a $U B L$. Assim, a língua é pensada em seu contexto de uso, ou seja, ao discurso, o qual se sobrepõe às regras gramaticais. Os objetivos do ensino de Língua Portuguesa estão estruturados em cinco eixos, "que dizem respeito a práticas e conhecimentos de linguagem: apropriação do sistema de escrita alfabético/ortográfico e de tecnologias da escrita, oralidade, leitura, escrita e análise linguística" (Brasil, 2015:38).

O ensino de Língua Portuguesa, no documento, guarda grandes semelhanças com os PCN, sobretudo no destaque que dá a informação sobre a prática da análise linguística, ao enfatizar que a perspectiva de ensino também deve ser Uso $\rightarrow$ Reflexão $\rightarrow$ Uso, no que diz respeito à sistematização e à utilização de categorias gramaticais. Os conceitos de letramento e gêneros textuais continuam sendo valorizados e aplicados nessa proposta de ensino comum. Assim, mais uma vez fica claro, em documentos oficiais, que a forma como se privilegia, em sala de aula, a abordagem da língua deve ser repensada, revista e reconstruída. Os objetivos gerais delimitados para o componente curricular Língua Portuguesa, segundo o documento em foco são demonstrados nas próximas figuras. 
1. planejar e realizar intervenções orais em situações públicas e analisar práticas utilizando diferentes gêneros orais (conversa, discussão, debate, entrevista, debate regrado, exposição oral), assim como desenvolver escuta atenta e crítica em situações variadas;

2. planejar, produzir, reescrever, revisar, editar e avaliar textos variados, considerando o contexto de produção e circulação (finalidades, gêneros, destinatários, espaços de circulação, suportes) e os aspectos discursivos, composicionais e linguísticos;

3. desenvolver estratégias e habilidades de leitura - antecipar sentidos e ativar conhecimentos prévios relativos aos textos, elaborar inferências, localizar informações, estabelecer relações de intertextualidade e interdiscursividade, apreender sentidos gerais do texto, identificar assuntos / temas tratados nos textos, estabelecer relações lógicas entre partes do texto - que permitam ler, com compreensão, textos de gêneros variados, sobretudo gêneros literários;

Figura 19 - Base Nacional Curricular Comum - página 43.

4. valorizar diferentes identidades sociais, lendo a apreciando a literatura das culturas tradicional, popular, afro-brasileira, africana, indígena e de outros povos e culturas;

5. refletir sobre a variação linguística, reconhecendo relações de poder na sociedade, combatendo as formas de dominação e preconceito que se fazem na e pela linguagem, sobre as relações entre fala e escrita em diferentes gêneros, assim como reconhecer e utilizar estratégias de marcação do nível de formalidade dos textos em suas produções;

6. utilizar e analisar diferentes estratégias de coesão e articulação entre partes do texto, tais como os recursos de retomadas (pronominalização, substituição lexical, uso de palavras de ligação) e as palavras e expressões que marcam a progressão do tempo na narrativa, as que estabelecem as relações de causalidade, oposição, consequência, explicação entre acontecimentos e ideias;

7. Ler, produzir e analisar textos multimodais, estabelecendo relações entre escrita, fala, sons, música, imagens (fotografias, telas, ilustrações, imagens em movimento, grafismos), dentre outras linguagens.

Figura 20 - Base Nacional Curricular Comum - página 44.

O Ensino Fundamental é o momento em que o aluno transita entre a infância e a adolescência, tem a base cognitiva estruturada ao longo dos anos iniciais da educação formal. Nele, desenvolve-se o que foi iniciado na Educação Infantil e prepara-se o terreno para o desenvolvimento de conhecimentos mais aprofundados que se darão no Ensino Médio. Assim, 
um trabalho bem feito para o cumprimento dos objetivos a serem alcançados durante esta etapa age efetivamente na formação de um cidadão crítico, agente em seu meio social.

Voltando-se para o sexto ano, alvo desta pesquisa, a BNCC propõe objetivos específicos, apresentados nas figuras subsequentes. Pode-se observar que há pouca ênfase no desenvolvimento de um olhar crítico nesse segmento, ao contrário do que é proposto neste trabalho. Assim, considera-se esse um ponto negativo da proposta em foco, pois analisar criticamente e defender seu ponto de vista são habilidades que devem ser trabalhadas desde os momentos iniciais do Ensino Fundamental, já que essas práticas estão presentes no cotidiano dos alunos, e nada garante que as escolas optarão por abordar tal questão. Retomando a BNCC, segue a proposta dos objetivos educacionais para o sexto ano.

\section{$6^{\circ}$ ANO}

\section{PRÁTICAS DA VIDA COTIDIANA}

Diz respeito à participação em situações de leitura/escuta, produção oral/escrita, próprias de atividades do dia a dia, no espaço doméstico/familiar, escolar, cultural, profissional que crianças, jovens e adultos vivenciam.

LILP6FOA163. Relatar oralmente o conteúdo de notícias veiculadas em jornais, revistas, televisão, rádio, Internet, exercitando a capacidade de selecionar e resumir;

LILP6FOA164. Compreender e produzir textos publicitários diversos, considerando o gênero (anúncio, classificado etc.) e o suporte (jornal, revista, TV, panfleto, outdoor, folder etc.).

\section{PRÁTICAS ARTÍSTICO-LITERÁRIAS}

Diz respeito à participação em situações de leitura/escuta, produção oral/escrita de textos que possibilitem conhecer produções culturais e literárias, valorizar nossa diversidade cultural e linguística, vivenciar experiências estéticas e de fruição literária.

LILP6FOA165. Relatar oralmente o enredo de obras literárias menos extensas, como contos, lendas, fábulas, mitos, reconstituindo coerentemente a sequência narrativa;

LILP6FOA166. Identificar os elementos que compőem as narrativas literárias, tais como tempo, espaço, construção dos personagens, foco narrativo, na leitura de textos da literatura juvenil, africana e indígenas;

LILP6FOA166. Produzir textos narrativos coesos e coerentes, observando a sequência das ações, a construçẫo de personagens e utilizando recursos verbais e/ou multimodais;

Figura 21 - Base Nacional Curricular Comum - página 65.

Nesses primeiros objetivos, observa-se a valorização de experiências cotidianas do aluno e a ênfase na prática da oralidade em sala de aula. Essas práticas são importantes para 
esta pesquisa, sobretudo em relação à oralidade, já que esta investigação traça um paralelo entre as regras de pontuação e a oralidade. Os livros didáticos atuais, porém, ainda não enfocam a língua oral de forma que ela possa auxiliar mais efetivamente a prática do texto escrito.

\section{PRÁTICAS ARTÍSTICO-LITERÁRIAS}

Diz respeito à participação em situações de leitura/escuta, produção oral/escrita de textos que possibilitem conhecer produçōes culturais e literárias, valorizar nossa diversidade cultural e linguística, vivenciar experiências estéticas e de fruição literária.

LILP6FOA167. Criar e recitar poemas de formas composicionais variadas, percebendo efeitos de sentido produzidos por recursos semânticos e sonoros;

LILP6FOA168. Compreender, lendo silenciosamente e de modo oralizado, poemas de formas composicionais variadas, apreendendo efeitos de sentido produzidos por recursos semânticos, sonoros e visuais;

LILP6FOA169. Identificar e analisar diálogos que os textos literários narrativos e poéticos estabelecem com outros textos, sobretudo no nível temático;

LILP6FOA170. Produzir poemas de gêneros variados, como haicais, sonetos, quadras, cordel, explorando a sonoridade $e$ os efeitos de sentido gerados.

\section{PRÁTICAS POLÍTICO-CIDADÃS}

Diz respeito à participação em situações de leitura/escuta, produção oral/escrita de textos, considerando especialmente aqueles das esferas jornalistica e publicitária, política, jurídica e reivindicatória e temas que impactam a cidadania e o exercício de direitos.

LILP6FOA171. Identificar as informaçöes que constituem o lide na leitura de notícias e reportagens impressas, televisivas, digitais (o quê, quem, onde, quando, como, por quê);

LILP6FOA172. Planejar a fala, em interações que exigem defesa de pontos de vista, mobilizando a capacidade de construir argumentos em situações que demandam atitude responsiva;

LILP6FOA173. Identificar as ideias defendidas ou refutadas por interlocutores em gêneros diversos orais e escritos como carta de leitor, postagens e comentários que circulam em redes sociais etc:;

Figura 22 - Base Nacional Curricular Comum - página 66.

\section{PRÁTICAS CULTURAIS DAS TECNOLOGIAS DE INFORMAÇÃO E COMUNICAÇÃO}

Diz respeito à participação em situações de leitura/escuta, produção oral/escrita de textos que possibilitem interagir em contextos de comunicação a distância e de compreender as características e os modos de produzir, divulgar e conservar informação, experimentando e criando linguagens e formas de interação em uma sociedade cada vez mais midiática.

LILP6FOA180. Mobilizar recursos multimodais na recepção e na produção de textos em diferentes mídias (jornal falado, programa radiofônico, blog etc.).

Figura 23 - Base Nacional Curricular Comum - página 68. 


\section{PRÁTICAS POLÍTICO-CIDADÃS}

Diz respeito à participação em situações de leitura/escuta, produção oral/escrita de textos, considerando especialmente aqueles das esferas jornalística e publicitária, política, jurídica e reivindicatória e temas que impactam a cidadania e o exercício de direitos.

LILP6FOA174. Responder, por escrito, a perguntas ou enquetes que exijam um posicionamento crítico, mobilizando argumentos consistentes e utilizando uma variedade linguística adequada à situação de comunicação;

LILP6FOA175. Compreender textos que regulam direitos e deveres, como o regimento da escola e combinados de sala de aula, avaliando a sua pertinência e funcionalidade.

\section{PRÁTICAS INVESTIGATIVAS}

Diz respeito à participação em situações de leitura/escuta, produção oral/escrita de textos que possibilitem conhecer os gêneros, a linguagem e as práticas relacionadas ao estudo e à pesquisa que favoreçam a aprendizagem dentro e fora da escola.

LILP6FOA176. Planejar e apresentar exposiçōes orais sobre temáticas diversas, a partir de fontes de estudos fornecidas pelo professor, adequando a linguagem (escolhas lexicais e estruturais) à situaçăo de produção escolar;

LILP6FOA177. Selecionar informações em textos diversos nas atividades de pesquisa, identificando temas e ideias principais e apresentando essa compreensäo sob a forma de apontamentos;

LILP6FOA178. Analisar e elaborar listas e tabelas, para compreender e organizar informações de textos expositivos em atividades de estudo e de pesquisa;

LILP6FOA179. Elaborar enquetes sobre temas relativos às diversas áreas do conhecimento e divulgar os resultados sob a forma de listas e tabelas.

Figura 24 - Base Nacional Curricular Comum - página 67.

Os defensores da adoção da BNCC apontam, como um de seus argumentos, que uma base comum a todas as escolas brasileiras possibilitará melhor formação de professores, que saberão o que devem, minimamente, trabalhar com seus alunos, e para isso serão preparados. Atualmente, o que os cursos de licenciaturas ensinam está distante da prática docente, e isso dificulta efetivas mudanças na educação. Em relação ao ensino de Língua Portuguesa, é fundamental que o professor seja preparado para a prática da análise linguística, pois essa exige especialização do docente, e o que se tem visto, ainda, é a manutenção do ensino tradicional no ensino dessa disciplina.

Neste estudo, ter em mente as questões de ensino e as expectativas de documentos oficiais acerca da educação na disciplina de Língua Portuguesa é fundamental no olhar para os dados. Diante das inovações teóricas, as opiniões dos alunos acerca do que lhes foi questionado e os resultados de suas produções de texto evidenciam a pouca prática do que a teoria apresenta 
como desejo de qualidade de ensino, e indiciam que a implementação, com eficiência, da BNCC será uma árdua tarefa.

\subsection{A pontuação em Língua Portuguesa}

Ao se abordar a pontuação em Língua Portuguesa, é inevitável tratar do que as Gramáticas Tradicionais da língua ensinam, já que apresentam as regras e indicam em que casos devem-se usar ou não a vírgula, por exemplo. Porém, antes de trazer para este trabalho o que Celso Cunha \& Lindley Cintra, José Carlos de Azeredo, Evanildo Bechara e Napoleão Gomes de Almeida postulam sobre a pontuação, será apresentada uma visão do tema alinhada aos pressupostos teóricos básicos desta pesquisa. Para tanto, enfocar-se-á o que Antônio Suarez de Abreu (2003) apresenta, principalmente, como a definição de pontuação, em sua "Gramática Mínima".

Abreu toma o modelo funcionalista-cognitivista para escrever sua obra, à exceção dos temas como ortografia e acentuação. Ele justifica sua escolha por esse modelo pela forma com que ele procura descrever os fatos da língua, com base em "como o usuário atribui sentido àquilo que escreve ou lê", em diversos contextos e necessidades de uso da língua, em diversas formas de interação via linguagem.

Com essa perspectiva, Abreu (2003) conceitua a pontuação do texto escrito, relacionando-a com a entonação dos textos orais e a intenção comunicativa do autor do discurso. Se esse pretende produzir uma frase declarativa na fala, produz-se "uma curva sonora em direção ao grave" (Abreu, 2003:247), entonação que será marcada na escrita pelo ponto final. Caso a intenção comunicativa seja indicar continuidade de uma ação ou suspense, a entonação do final da frase se mantém nivelada com a do início, sendo marcada na escrita pelo uso de reticências. Quando, ao final de uma frase, a curva entonacional se eleva, intenciona-se produzir uma pergunta, representada na escrita pelo ponto de interrogação. Quando a pergunta exige uma resposta que seja sim ou não, a entonação apresenta uma marca diferenciada, em que a proeminência da curva entonacional recai sobre o pronome interrogativo. Ao ponto de exclamação o autor atribui a expressão de emoções, e a curva entonacional seria ascendente final, com alongamento da última vogal tônica da frase. 
No que tange ao uso da vírgula, o linguista explica que, na fala, as palavras não são pronunciadas isoladamente, mas sim em grupos entonacionais ou grupos prosódicos ${ }^{33}$. Dessa forma, uma oração simples, como “A importância da leitura é muito grande” (PT023) ${ }^{34}$, é pronunciada como um único bloco prosódico, sem pausas. Porém, quando há a necessidade de se reunir orações, como em "Quando você lê um livro / você tem que entender o que está acontecendo na história” (PT042), na fala, há uma necessidade natural de separar a oração subordinada da principal, nesse caso específico. Isso porque cada uma delas corresponde a um grupo prosódico. Na escrita, segundo o autor, essa quebra de ligação entonacional seria marcada por uma vírgula. Seguindo essa linha de raciocínio, as vírgulas, são

recursos gráficos utilizados para assinalar, na escrita, as quebras de ligação entonacional marcadas pela sintaxe e que promovem o "empacotamento ${ }^{35 "}$ " das frases de um texto em blocos prosódicos. Estudar o emprego da vírgula é, portanto, aprender a assinalar, na escrita, as quebras de ligação entonacional originadas na sintaxe das frases (Abreu, 2003: 251).

O autor chama atenção para as regras de criação de grupos prosódicos, pois esses estão relacionados à sintaxe de uma frase, e, segundo ele, a inserção equivocada da barreira entonacional pode prejudicar a estrutura e o sentido da informação. Abreu exemplifica essa questão com o exemplo de uma possível frase proferida em uma feira livre, dita por um feirante que trabalha em uma barraca de frutas: "Olha a manga gostosa".

Se o feirante dissesse à freguesa: /Olha a manga gostosa!/, empacotando a frase em um único bloco prosódico, a palavra manga é que seria afetada pelo adjetivo gostosa. Mas, maliciosamente, ele quebra a ligação entre o substantivo manga e o adjetivo gostosa, dizendo: /Olha a manga / gostosa!/.

Isso altera a sintaxe da frase, fazendo com que o adjetivo gostosa passe a ter como referência a própria freguesa. (Abreu, 2003: 251)

Com base no conceito das ligações entonacionais, ou "empacotamentos sintáticoprosódicos", como Abreu as denomina, o autor define as situações em que se deve usar a vírgula e a situação em que não se deve usá-la. Ele inicia explicando que entre o verbo e seus complementos obrigatórios sintaticamente, sujeito e demais complementos, não há quebra entonacional, portanto não há o uso de vírgulas ainda que esses estejam fora da posição padrão.

\footnotetext{
${ }^{33}$ Para maiores informações sobre esses dois conceitos, conferir o Capítulo 1.

34 As informações acompanhadas do código PT (produção de texto) fazem parte do corpus de análise. São exemplos retirados das produções textuais dos alunos do sexto ano da Escola Internacional.

${ }^{35} \mathrm{O}$ termo não é totalmente equivalente a empacotamento informacional, information packaging, termo próprio dos estudos relativos à Estrutura Informacional.
} 
O quadro a seguir apresenta uma síntese das situações em que há a necessidade do uso da vírgula, de acordo com o autor. Seguindo a lógica de Abreu, as quebras prosódicas serão marcadas pelo uso de barras (/).

\begin{tabular}{|c|c|}
\hline $\begin{array}{l}\text { Situações em que se pode haver quebra } \\
\text { entonacional ou não (vírgula opcional). }\end{array}$ & $\begin{array}{c}\text { Situações em que há quebra entonacional, } \\
\text { obrigatoriamente. }\end{array}$ \\
\hline $\begin{array}{l}\text { Adjuntos adverbiais em posição padrão, } \\
\text { ou seja, em final de oração. } \\
\text { /Paula deu presente ao namorado ontem/. } \\
\text { /Paula deu presente ao namorado/ ontem/. } \\
\text { Paula deu presente ao namorado, ontem. }\end{array}$ & $\begin{array}{l}\text { Adjuntos adverbiais sob forma de } \\
\text { orações. } \\
\text { /Paula deu presente ao namorado/ quando } \\
\text { chegou o Natal/. } \\
\text { /Paula /quando chegou o Natal/ deu presente ao } \\
\text { namorado. } \\
\text { /Quando chegou o Natal/ Paula deu presente ao } \\
\text { namorado/. }\end{array}$ \\
\hline $\begin{array}{l}\text { Quando há mais de um adjunto, ainda em } \\
\text { posição padrão, ao menos uma quebra } \\
\text { precisará ser feita. } \\
\text { /Paula deu presente ao namorado/ ontem depois } \\
\text { do jantar/. } \\
\text { /Paula deu presente ao namorado ontem/ depois } \\
\text { do jantar/. }\end{array}$ & $\begin{array}{l}\text { Termos da mesma função não ligados por } \\
\text { conjunção (enumeração). } \\
\text { Idem, ibidem. } \\
\text { Paula, Joana e Ângela compraram presentes. }\end{array}$ \\
\hline $\begin{array}{l}\text { Adjuntos adverbiais fora da posição } \\
\text { padrão. } \\
\text { /Ontem/Paula deu presente ao namorado/. } \\
\text { /Paula / ontem/deu presente ao namorado/. } \\
\text { /Paula deu presente/ ontem/ ao namorado/. }\end{array}$ & $\begin{array}{l}\text { Orações coordenadas aditivas ligadas por } \\
\text { E, se os sujeitos forem diferentes. } \\
\text { Paula deu presente ao namorado, e ele não } \\
\text { gostou. }\end{array}$ \\
\hline & $\begin{array}{l}\text { Termos de uma mesma função sob forma } \\
\text { de oração. }\end{array}$ \\
\hline & $\begin{array}{l}\text { Conjunções coordenativas deslocadas } \\
\text { para o meio da oração. }\end{array}$ \\
\hline & $\begin{array}{l}\text { Orações ou fragmentos de oração } \\
\text { deslocados dentro de outra oração. }\end{array}$ \\
\hline & Aposto explicativo. \\
\hline & Vocativo. \\
\hline & Expressões explicativas ou de retificação. \\
\hline & Orações adjetivas explicativas. \\
\hline & Elipse do verbo. \\
\hline & Tópicos de oração. \\
\hline & Antitópicos de oração. \\
\hline
\end{tabular}

Tabela 2 - Situações de uso da vírgula, por Abreu, 2003.

A perspectiva de Abreu (2003) é interessante e, de fato, esclarece a relação entre o ritmo, da fala, e a pontuação própria da escrita. Porém há um caso específico que essa análise pode 
não contemplar. Em casos de sujeitos oracionais, é possível haver uma quebra prosódica que separa sujeito e verbo, situação apresentada pelo estudioso como não passível a quebras dessa natureza. Um exemplo seria a frase 'Os problemas econômicos que o país enfrenta abalaram a confiança no governo'. Não soaria estranha, aos ouvidos dos falantes nativos do português brasileiro, a ocorrência de uma quebra entonacional da seguinte forma nessa frase: '/Os problemas econômicos que o país enfrenta / abalaram a confiança no governo\% Contudo, sintaticamente, não é aceitável o uso de vírgula antes do verbo "abalaram", dessa forma, é importante considerar que o "empacotamento sintático-prosódico" pode apresentar ainda algumas lacunas em relação às explicações do uso da vírgula.

Celso Cunha e Lindley Cintra (2001: 644) apresentam a vírgula como a representação escrita de uma pausa de curta duração. Para eles, a vírgula pode ser usada para separar elementos de uma oração e também orações de um só período. Os autores admitem que há alguns casos em que o emprego da vírgula não corresponde a uma pausa real, e exemplificam com o exemplo das respostas rápidas, como "Sim, senhor”. Além disso, Cunha \& Cintra (2001: 650) destacam, na conclusão da explanação sobre o uso da vírgula, que toda oração ou termo de valor meramente explicativo são pronunciados entre pausas, por isso a necessidade de se usar a vírgula no texto escrito, e que os termos essenciais e integrantes da oração são ligados uns aos outros sem pausa, na fala, por isso não se pode usar vírgulas entre uma oração principal e uma oração subordinada substantiva.

\begin{tabular}{|c|c|c|c|}
\hline $\begin{array}{l}\text { A vírgula - Cunha \& } \\
\text { Cintra (2001) }\end{array}$ & $\begin{array}{l}\text { Uso da vírgula: Casos } \\
\text { gerais. - Azeredo (2008) }\end{array}$ & $\begin{array}{l}\text { Uso da } \quad \begin{array}{r}\text { vírgula } \\
\text { obrigatório } \\
(2009)\end{array} \\
\text { Bechara }\end{array}$ & $\begin{array}{l}\text { Emprego da vírgula - } \\
\text { Almeida (2009) }\end{array}$ \\
\hline $\begin{array}{l}\text { Separar elementos que } \\
\text { exercem a mesma função } \\
\text { sintática, quando não vêm } \\
\text { unidos pelas conjunções } \\
\text { e, ou, nem. } \\
\text { OBS.: Quando as } \\
\text { conjunções e, ou, nem } \\
\text { vêm repetidas em uma } \\
\text { enumeração, costuma-se } \\
\text { separar por vírgula os } \\
\text { elementos coordenados. }\end{array}$ & $\begin{array}{l}\text { Separação de orações ou } \\
\text { termos coordenados sem } \\
\text { a utilização de } \\
\text { conectivos. } \\
\text { OBS.: Nas orações } \\
\text { introduzidas pela } \\
\text { conjunção E, pode-se } \\
\text { empregar a vírgulas (a) } \\
\text { quando apresentam } \\
\text { sujeitos diferentes, (b) } \\
\text { quando os conectivos } \\
\text { estiverem repetidos numa } \\
\text { sequência enumerativa, } \\
\text { caracterizando r o } \\
\text { polissíndeto, } \\
\text { elementos coordenados } \\
\text { podem ser separados por } \\
\text { vírgula. }\end{array}$ & 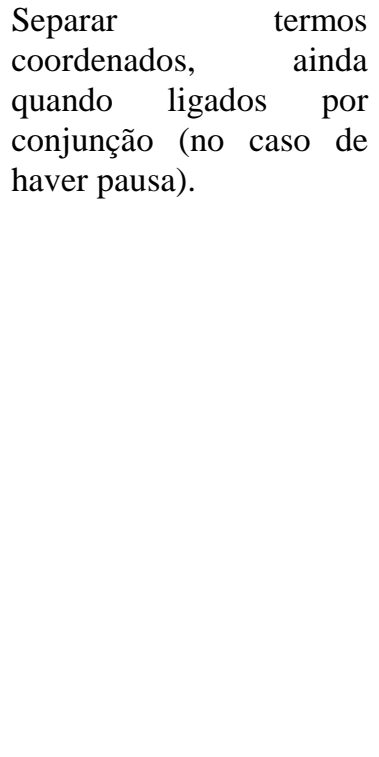 & $\begin{array}{l}\text { Emprega-se a vírgula } \\
\text { entre palavras, membros } \\
\text { e orações de idêntica } \\
\text { função; ou } \\
\text { emprega-se a vírgula } \\
\text { entre vários sujeitos, } \\
\text { vários objetos ou entre } \\
\text { orações independentes, } \\
\text { assindéticas. }\end{array}$ \\
\hline
\end{tabular}




\begin{tabular}{|c|c|c|c|}
\hline 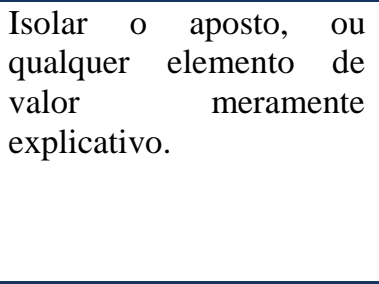 & $\begin{array}{l}\text { Aposição explicativa ou } \\
\text { circunstancial em geral. }\end{array}$ & $\begin{array}{l}\text { Separar orações } \\
\text { coordenadas aditivas, } \\
\text { ainda que sejam iniciadas } \\
\text { pela conjunção E, } \\
\text { proferidas com pausa. }\end{array}$ & $\begin{array}{l}\text { Marcar pausa no fim da } \\
\text { subordinada adjetiva } \\
\text { restritiva, quando esta é } \\
\text { constituída por dizeres } \\
\text { muito longos (nesse } \\
\text { caso, pode separar } \\
\text { sujeito de verbo). }\end{array}$ \\
\hline Isolar o vocativo. & Separação do vocativo. & $\begin{array}{l}\text { Separar } \\
\text { coordenadas alternativães } \\
\text { (ou, quer, etc), quando } \\
\text { proferidas com pausa. } \\
\text { Quando denota } \\
\begin{array}{l}\text { equivalência não há } \\
\text { vírgula. }\end{array}\end{array}$ & $\begin{array}{l}\text { Para evitar ambiguidade } \\
\text { na sínquise ou } \\
\text { deslocação violenta dos } \\
\text { complementos. }\end{array}$ \\
\hline $\begin{array}{l}\text { Isolar os elementos } \\
\text { repetidos. }\end{array}$ & $\begin{array}{l}\text { Separação de adjunto } \\
\text { adverbial anteposto. } \\
\text { Opcional quando o } \\
\text { adjunto é um advérbio ou } \\
\text { SPrep estritamente de } \\
\text { circunstância (de lugar, } \\
\text { tempo ou modo), a } \\
\text { vírgula se torna, porém, } \\
\text { necessária se o adjunto } \\
\text { tem função modalizadora } \\
\text { ou é uma oração, } \\
\text { desenvolvida ou } \\
\text { reduzida. } \\
\text { OBS.: Pode-se separar ou } \\
\text { isolar por vírgula o } \\
\text { adjunto adverbial na sua } \\
\text { ordem natural, quando se } \\
\text { quer realça-lo. }\end{array}$ & $\begin{array}{l}\text { Em aposições, exceto de } \\
\text { valor explicativo. }\end{array}$ & $\begin{array}{l}\text { Para separar nas datas o } \\
\text { nome da localidade. }\end{array}$ \\
\hline $\begin{array}{l}\text { Isolar o adjunto adverbial } \\
\text { antecipado. } \\
\text { OBS.: Quando os } \\
\text { adjuntos adverbiais são } \\
\text { de pequeno corpo (um } \\
\text { advérbio, por exemplo), } \\
\text { costuma-se dispensar a } \\
\text { vírgula. Essa, porém, é } \\
\text { regra quando se pretende } \\
\text { realça-los. }\end{array}$ & $\begin{array}{l}\text { Uso de palavras e } \\
\text { locuções que expressam } \\
\text { conexões discursivas em } \\
\text { geral (adição, explicação, } \\
\text { contraste, compensação, } \\
\text { retificação, } \\
\text { encadeamento, } \\
\text { conclusão, ratificação } \\
\text { etc.). }\end{array}$ & $\begin{array}{l}\text { Separar, em gral, os } \\
\text { pleonasmos e as } \\
\text { repetições (quando não } \\
\text { têm } \\
\text { superlativamente). valor }\end{array}$ & $\begin{array}{l}\text { Para indicar zeugma do } \\
\text { verbo. }\end{array}$ \\
\hline $\begin{array}{l}\text { Separar, na datação de um } \\
\text { escrito, o nome do lugar. }\end{array}$ & $\begin{array}{lll}\text { Elipse do verbo } & \text { em } \\
\text { estruturas } & & \text { de } \\
\text { coordenação. } & & \\
\end{array}$ & $\begin{array}{l}\text { Separar ou intercalar } \\
\text { vocativos. }\end{array}$ & $\begin{array}{l}\text { Para separar elementos } \\
\text { paralelos de uma } \\
\text { expressão proverbial. }\end{array}$ \\
\hline $\begin{array}{l}\text { Indicar a supressão de } \\
\text { uma palavra (geralmente } \\
\text { o verbo) ou de um grupo } \\
\text { de palavras). }\end{array}$ & $\begin{array}{l}\text { Separação de oração } \\
\text { coordenada que não seja } \\
\text { aditiva. }\end{array}$ & $\begin{array}{lrr}\begin{array}{l}\text { Separar as orações } \\
\text { adjetivas de } \\
\text { explicativo. }\end{array} & & \\
\text { valor }\end{array}$ & $\begin{array}{l}\text { Para separar certas } \\
\text { conjunções } \\
\text { pospositivas, tais como } \\
\text { porém, contudo, pois, } \\
\text { todavia... } \\
\text { OBS.: Porém, contudo e } \\
\text { outras podem dispensar } \\
\text { a vírgula. }\end{array}$ \\
\hline
\end{tabular}




\begin{tabular}{|c|c|c|c|}
\hline $\begin{array}{l}\text { Separar orações } \\
\text { coordenadas assindéticas. }\end{array}$ & $\begin{array}{l}\text { Acréscimo de oração } \\
\text { justaposta para o registro } \\
\text { de algum ato de fala } \\
\text { (neste caso, também se } \\
\text { usa o travessão). }\end{array}$ & $\begin{array}{l}\text { Separar, quase sempre, as } \\
\text { orações adjetivas } \\
\text { restritivas de certa } \\
\text { extensão, principalmente } \\
\text { quando os verbos das } \\
\text { duas orações se juntam. }\end{array}$ & $\begin{array}{l}\text { Para dar ênfase a certas } \\
\text { conjunções, advérbios e } \\
\text { locuções adverbiais. } \\
\text { OBS.: Não se usa } \\
\text { vírgula depois de 'pois', } \\
\text { 'mas', 'todavia', 'logo' } \\
\text { quando essas iniciam } \\
\text { oração coordenada, } \\
\text { exceto quando colocada } \\
\text { para dar ênfase a alguma } \\
\text { expressão que segue. } \\
\text { É também erro colocar } \\
\text { sistematicamente entre } \\
\text { vírgulas advérbios e } \\
\text { locuções adverbiais. Só } \\
\text { devem aparecer quando } \\
\text { houver enfor a } \\
\text { obrigando o leitor a } \\
\text { notar a força do advérbio } \\
\text { ou da locução. }\end{array}$ \\
\hline 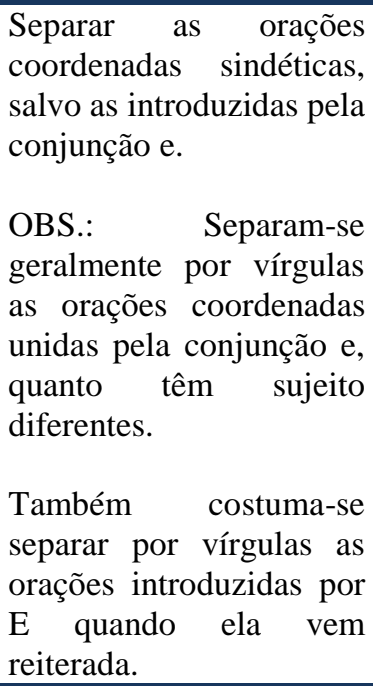 & $\begin{array}{l}\text { Emprego de coordenadas } \\
\text { por processo correlativo } \\
\text { em geral. }\end{array}$ & $\begin{array}{ll}\text { Separar } & \text { orações } \\
\text { intercaladas. } & \end{array}$ & $\begin{array}{l}\text { Depois de sim ou não } \\
\text { colocados no início da } \\
\text { sentença. }\end{array}$ \\
\hline $\begin{array}{l}\text { Em relação às conjunções } \\
\text { adversativas, quando } \\
\text { essas vêm no início da } \\
\text { oração (principalmente, } \\
\text { MAS) põe-se uma vírgula } \\
\text { antes da conjunção. } \\
\text { Quando essas conjunções } \\
\text { vêm após algum termo da } \\
\text { oração, elas precisam } \\
\text { estar isoladas por } \\
\text { vírgulas. }\end{array}$ & $\begin{array}{l}\text { Separação de orações } \\
\text { reduzidas que não sejam } \\
\text { constituintes imediatos de } \\
\text { um termo da oração } \\
\text { principal. }\end{array}$ & $\begin{array}{l}\text { Separar, em geral, } \\
\text { adjuntos adverbiais que } \\
\text { precedem o verbo e as } \\
\text { orações adverbiais que } \\
\text { vêm antes ou no meio da } \\
\text { sua principal. }\end{array}$ & $\begin{array}{l}\text { Depois de 'assim', } \\
\text { 'então', 'demais' e de } \\
\text { outros advérbios e } \\
\text { locuções adverbiais em } \\
\text { princípios de sentenças, } \\
\text { com sentido de } \\
\text { conjunção. }\end{array}$ \\
\hline $\begin{array}{l}\text { Isolar a conjunção POIS } \\
\text { (conclusiva), que sempre } \\
\text { vem posposto a um termo } \\
\text { da oração. }\end{array}$ & $\begin{array}{l}\text { Antecipação } \\
\text { (topicalização) de um } \\
\text { termo que será retomado } \\
\text { por um pronome. }\end{array}$ & $\begin{array}{l}\text { Separar, nas datas, o } \\
\text { nome do lugar. }\end{array}$ & $\begin{array}{l}\text { Para separar certas } \\
\text { locuções explanatórias, } \\
\text { tais como, 'isto é', 'por } \\
\text { exemplo'... }\end{array}$ \\
\hline $\begin{array}{l}\text { Isolar } \quad \text { orações } \\
\text { intercaladas. }\end{array}$ & & $\begin{array}{l}\text { Separar partículas e } \\
\text { expressões de explicação, } \\
\text { correção, continuação, } \\
\text { conclusão, concessão. }\end{array}$ & $\begin{array}{l}\text { O vocativo vem sempre } \\
\text { acompanho de vírgula } \\
\text { quando inicia a oração. }\end{array}$ \\
\hline
\end{tabular}




\begin{tabular}{|c|c|c|}
\hline $\begin{array}{lr}\text { Isolar } & \text { orações } \\
\text { subordinadas } & \text { adjetivas } \\
\text { explicativas. } & \end{array}$ & $\begin{array}{l}\text { Separar as conjunções e } \\
\text { os advérbios } \\
\text { adversativos, } \\
\text { principalmente quando } \\
\text { pospostos. }\end{array}$ & $\begin{array}{l}\text { Pode a vírgula ser } \\
\text { empregada } \\
\text { enfaticamente em lugar } \\
\text { do verbo 'ser' em } \\
\text { orações de fácil } \\
\text { compreensão. }\end{array}$ \\
\hline $\begin{array}{l}\text { Separar as orações } \\
\text { subordinadas adverbiais, } \\
\text { principalmente quando } \\
\text { antepostas à principal. }\end{array}$ & $\begin{array}{l}\text { Indicar, às vezes, elipse } \\
\text { do verbo. }\end{array}$ & $\begin{array}{l}\text { Introduzindo-se num } \\
\text { período um parêntese } \\
\text { em lugar onde já haja a } \\
\text { vírgula, esta se coloca } \\
\text { depois de fechado os } \\
\text { parênteses, uma vez que } \\
\text { este sempre esclarece o } \\
\text { que ficou antes da } \\
\text { vírgula, e não o que vem } \\
\text { depois dela. }\end{array}$ \\
\hline $\begin{array}{l}\text { Separar as orações } \\
\text { reduzidas de infinitivo, de } \\
\text { gerúndio e de particípio, } \\
\text { quando equivalentes a } \\
\text { orações adverbiais. }\end{array}$ & $\begin{array}{l}\text { Assinalar a interrupção } \\
\text { de um segmento natural } \\
\text { das ideias e se intercala } \\
\text { um juízo de valor ou uma } \\
\text { reflexão. }\end{array}$ & \\
\hline & $\begin{array}{l}\text { Desfazer possível má } \\
\text { interpretação resultante } \\
\text { da distribuição irregular } \\
\text { dos termos da oração, } \\
\text { separa-se por vírgula a } \\
\text { expressão deslocada. }\end{array}$ & \\
\hline
\end{tabular}

Tabela 3 - A vírgula segundo quatro gramáticas tradicionais.

Azeredo (2008) inicia sua explicação sobre a pontuação com a explanação sobre a entonação, que é vista como como expressão portadora de sentido, e como elemento discursivo, capaz de revelar, ou camuflar, a intenção comunicativa do falante. O estudioso também menciona a relação entre entonação, pausa e uso da vírgula, o que interessa especialmente a essa pesquisa. Ele menciona a obrigatoriedade sintática da vírgula e reconhece que nem sempre a relação entre fala e escrita será positiva.

Segundo Bechara (2009), a pontuação está relacionada à entonação, e são pausas, orais e escritas. O gramático indicou que é possível entender a pontuação de duas maneiras: larga (abarca sinais de pontuação e de realce) e restrita (abarca somente sinais de pontuação). Independentemente das maneiras de se entender a pontuação, ela desempenha papel discursivo fundamental. Nota-se que Bechara não enfatizou a relação entre uso de vírgula na escrita e a pausa, típica da oralidade. Além desses gramáticos, Almeida (2009) também trata sobre a vírgula, e a relaciona à pausa na oralidade. Ele ainda chama atenção para a não relação exata entre pausa e uso da vírgula, o que pode levar ao uso desse sinal de pontuação, na língua escrita, em situações sintaticamente erradas. Almeida (2009) e seus ensinamentos sobre o uso da pontuação já foi enfocado anteriormente. 


\subsection{Matrizes de correção das produções de texto - ENEM e CEBRASPE}

Um dos importantes pontos desta pesquisa foi a decisão de como as produções de texto dos alunos seriam analisadas. Todo o embasamento teórico tem como centro a visão de a linguagem ser meio para a comunicação e de que a língua se constrói no uso, ou seja, durante o processo comunicativo. Com isso, uma pergunta, na pesquisa, foi: que critérios serão usados para analisar o uso da língua portuguesa feito pelos alunos do sexto ano em seus textos escritos?

A resposta direcionou o estudo para os manuais de ensino tradicionais da língua portuguesa; isso em razão da forma como a escola encaminha o ensino de língua portuguesa, independentemente das orientações dos PCN, como apresentado na seção anterior. Assim, neste trabalho será feita uma comparação do uso da língua pelos alunos com as regras da chamada norma culta presente nas gramáticas tradicionais. Os desvios do uso dos alunos em relação ao padrão normativo serão analisados sob a perspectiva da $U B L$.

No universo de regras trazidas pelos manuais de ensino, foi preciso delimitar o que seria analisado, e, para tanto, foi necessário pensar nas estruturas básicas para compor um texto escrito de qualidade, considerando-se o nível de escolaridade dos alunos que foram os informantes desta pesquisa. Com isso em mente, tomou-se a decisão de investigar como exames que avaliam a produção de texto dos alunos analisam e mensuram a estrutura linguística e argumentativa apresentada nos textos.

Assim, decidiu-se tomar como base duas grades de correção de avaliação em larga escala: a grade do Exame Nacional do Ensino Médio $\left(\mathrm{ENEM}^{36}\right)$ e a do vestibular da Universidade de Brasília, organizado pelo Centro Brasileiro de Pesquisa em Avaliação de Seleção e de Promoção de Eventos ${ }^{37}$ (CESPE/CEBRASPE, doravante CEBRASPE). Ambas as tabelas estão disponíveis na Internet, foram utilizadas para os exames aplicados no ano de 2013 e foram a última atualização disponível, encontrada pela pesquisadora. Essas grades de correção foram adaptadas às necessidades de pesquisa, por isso não foram usadas integralmente.

\footnotetext{
${ }^{36}$ Disponível em

http://download.inep.gov.br/educacao_basica/enem/guia_participante/2013/guia_de_redacao_enem_2013.pdf acesso 03 de março de 2015.

${ }^{37}$ Disponível em

http://www.cespe.unb.br/vestibular/vestunb_13_1/arquivos/CRIT_RIOS_ADOTADOS_NA_AVALIA___O_DE_ASPEC TOS_MICROESTRUTURAIS.PDF acesso 03 de março de 2015.

Versão mais recente foi lançada no mês de novembro de 2015, e pode ser encontrada em http://www.cespe.unb.br/pas/.
} 
A grade de correção do ENEM é chamada, no Guia do Participante, de "Matriz de referência para redação" e apresenta cinco competências a serem avaliadas nas redações dos participantes do exame. Ainda de acordo com o guia, as competências são as apresentadas a seguir.

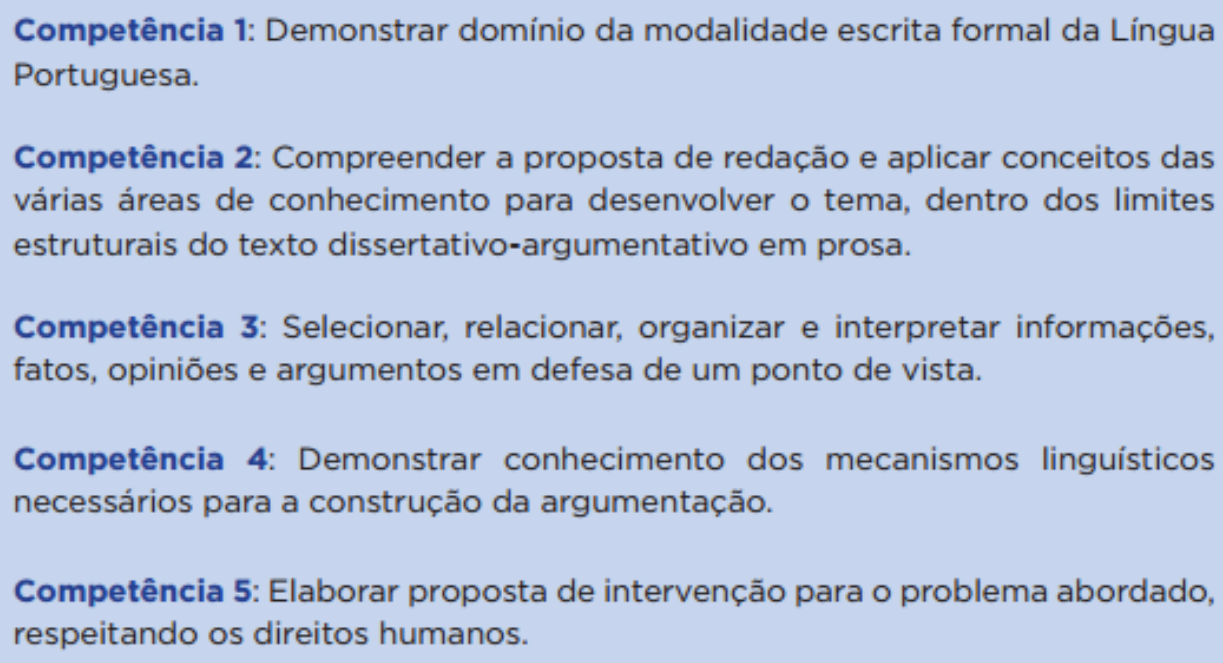

Figura 25 - Guia do Participante - ENEM 2013, página 8.

As competências propostas nesta matriz de referência embasaram os macrocritérios de análise, adaptados ao público-alvo. A Competência 1 foi mantida, sendo ampliada para este trabalho e dividida em análise relativa à Escrita Formal e à Pontuação. A Competência 2 foi adaptada, e a compreensão da proposta foi verificada, com relação à manutenção temática e ao atendimento ao tipo textual solicitado, no caso o argumentativo. A Competência 3 não foi considerada nesta pesquisa e a 4 foi investigada em relação à coesão textual, na qual a pontuação do texto também interfere. Por essa razão foi criado um macrocritério focado nela. A Competência 5 não foi considerada nesta análise, tendo em vista que, no momento das coletas de dados, os alunos ainda não tinham sido estimulados a trabalhar com a perspectiva de propor solução para o problema em pauta, foco dessa competência.

A descrição, no documento, da Competência 1 foi importante na delimitação do que seria analisado nos dados. Nela, a distinção entre fala e escrita é o primeiro ponto a ser abordado no que diz respeito à escrita formal, e é um dos critérios avaliados nessa competência, já que alcançam maior pontuação aqueles que demonstrarem maior domínio da modalidade escrita da língua portuguesa. Em uma breve análise da escrita em qualquer nível de ensino, são notáveis os problemas que os brasileiros têm na grafia das palavras, sobretudo pela influência da fala. 
Por isso esse ponto é importante para a análise aqui proposta, já que, para escrever conforme as convenções da língua escrita padrão, é preciso saber os limites entre fala e escrita. O guia apresenta os requisitos básicos para se produzir um texto dissertativo-argumentativo, de acordo com a perspectiva do exame, que será reproduzido a seguir.

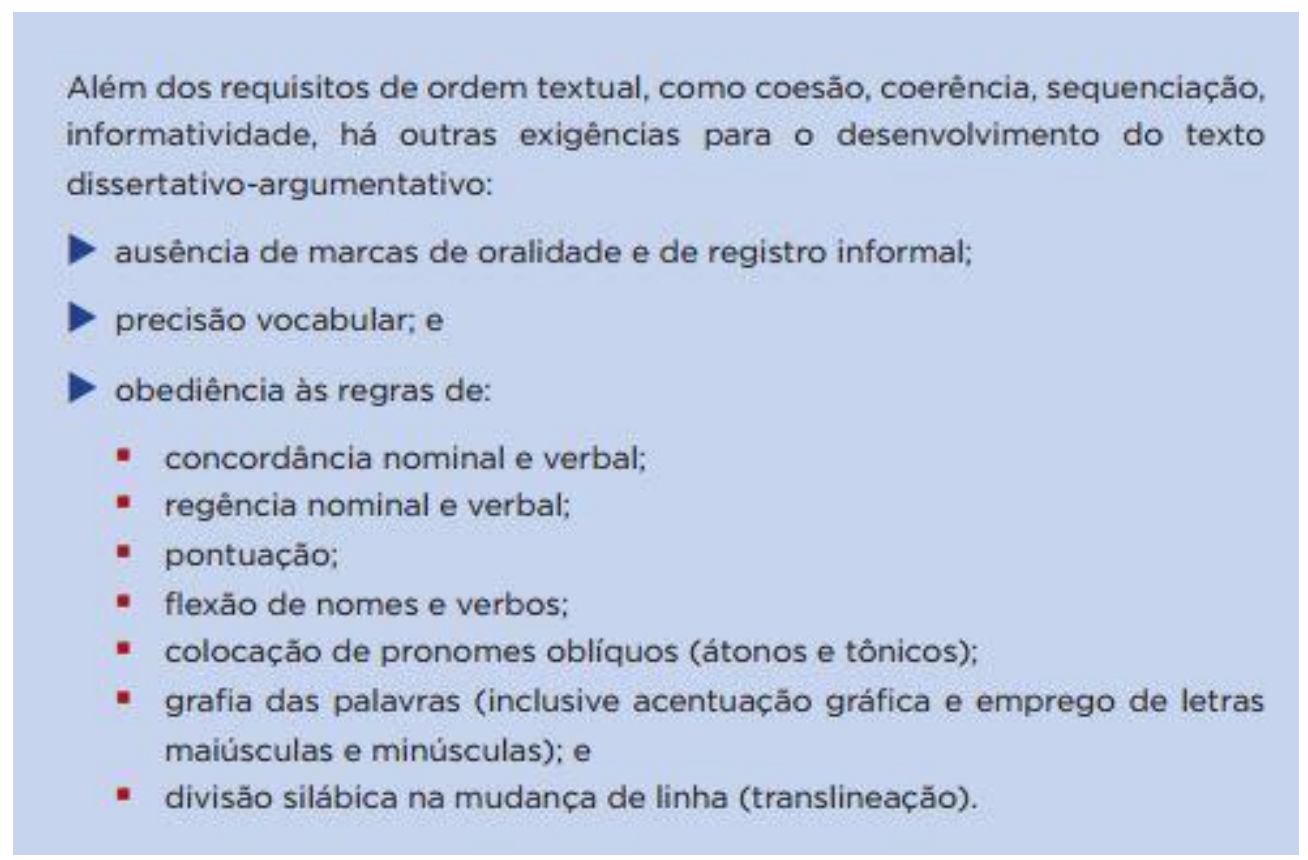

Figura 26 - Guia do Participante - ENEM 2013, página 12.

A primeira exigência, como já mencionado, diz respeito à distinção entre escrita e oralidade, e as demais seguem o mesmo viés, tanto que foram critérios analisados neste trabalho, à exceção da translineação (separação de sílabas no final da linha). É importante insistir nessa dicotomia pois, à primeira vista, ela parece óbvia, contudo os dados apontam para ser a "Escrita Formal" um dos pontos críticos do ensino de Língua Portuguesa. As regras elencadas no trecho anterior do guia motivaram os microcritérios de análise dos erros dos alunos, que foram avaliados por presença ou ausência de erro de grafia das palavras, por exemplo.

Uma importante questão é destacar é que a escolha desta matriz de referência também tem relação com a relevância do ENEM para a educação brasileira, já que o exame como um todo afere a qualidade da educação brasileira. A Escola Internacional tem uma clientela elitizada, e, mesmo nela, os dados indicam que os alunos chegam ao Ensino Fundamental II com problemas que necessitarão ser trabalhados com afinco para que, ao final da Educação Básica, a escola tenha cumprido seu papel ante as dificuldades da escrita formal. Na perspectiva 
da $U B L$, é do uso que emergem as regras da língua, e esse faz com que seja cada vez maior o distanciamento entre fala e escrita, mesmo com a interferência da escola.

A Competência 2 avalia a compreensão do participante em relação à proposta de redação, e o primeiro passo para isso é que o texto produzido seja dissertativo-argumentativo. Se o aluno escreve um texto narrativo, por exemplo, ele não atende à proposta e tem seu texto zerado. Dentre os critérios avaliados nessa competência, foram mantidos, nesta pesquisa, a pertinência à tipologia e ao tema, assim, se o aluno do sexto ano produzisse um texto narrativo, ou desenvolvesse uma argumentação a qual divergisse do que lhe foi solicitado na proposta de redação, configurar-se-ia erro, nesta tese, com base na Competência 2 do ENEM.

$\mathrm{O}$ exame, em relação à Competência 3, avalia a seleção dos argumentos em prol da defesa de um ponto de vista. Assim mensura a coerência entre as ideias defendidas e sua plausibilidade, além de valorizar a autoria, ou seja, a não cópia dos textos motivadores da proposta. Como já foi mencionado, essa competência não foi considerada entre os critérios de análise desta pesquisa, por ser um momento em que o aluno começa a ter contato com textos argumentativos e com o formato de redação como é proposto no ENEM.

A coesão é o foco da Competência 4, na qual se avalia a organização textual na relação entre frases e parágrafos (entre si e em relação ao texto como um todo), e no desenvolvimento das ideias. É nela que se verifica o uso de elementos conectivos, estratégias de retomada e introdução de ideias e termos. Essa competência motivou o macrocritério Coesão desta pesquisa. Segundo o guia, os critérios a seguir serão avaliados nessa competência.

Para garantir a coesão textual, devem ser observados determinados princípios em diferentes níveis:

Estruturação dos parágrafos - um parágrafo é uma unidade textual formada por uma ideia principal à qual se ligam ideias secundárias. No texto dissertativoargumentativo, os parágrafos podem ser desenvolvidos por comparação, por causaconsequência, por exemplificação, por detalhamento, entre outras possibilidades. Deve haver uma articulação entre um parágrafo e outro.

Estruturação dos períodos - pela própria especificidade do texto dissertativoargumentativo, os períodos do texto são, normalmente, estruturados de modo complexo, formados por duas ou mais orações, para que se possa expressar as ideias de causa-consequência, contradição, temporalidade, comparação, conclusão, entre outras.

Referenciação - as referências a pessoas, coisas, lugares e fatos são introduzidas e, depois, retomadas, à medida que o texto vai progredindo. Esse processo pode ser expresso por pronomes, advérbios, artigos ou vocábulos de base lexical, estabelecendo relações de sinonímia, antonímia, hiponímia, hiperonímia, uso de expressões resumitivas, expressões metafóricas ou expressões metadiscursivas. (ENEM, 2013:20). 
O documento do CEBRASPE (2013: 2) que foi considerado nesta pesquisa não é um guia detalhado como o do ENEM, é a apresentação de "alguns critérios de avaliação de aspectos microestruturais da prova de redação e de questões do tipo D do $1^{\circ}$ Vestibular de 2013 da Universidade de Brasília - UnB”. Assim como a matriz anterior, esta também foi adaptada aos dados e não foi utilizada integralmente. $\mathrm{O}$ documento em foco não contempla todos os aspectos formais de um texto, mas serve à proposta de uma correção padronizada das redações dos candidatos a uma vaga na Universidade de Brasília. A seleção de aspectos microestruturais abordados tem como critério a "incidência dos erros relativos a tais aspectos nos textos avaliados e atualização de regras em gramáticas normativas de referência”. (idem, ibidem)

O documento do CEBRASPE apresenta grafia/acentuação gráfica, morfossintaxe e propriedade vocabular como os aspectos avaliados na correção das redações. É válido mencionar que a grade de avaliação dos referidos exames não contempla apenas a análise de critérios microestruturais. Há também uma avaliação de aspectos macroestruturais, que não são contemplados no documento em foco e que não foi considerada, pela pesquisadora, para esta pesquisa. Os três aspectos apresentados são subdivididos da seguinte maneira.

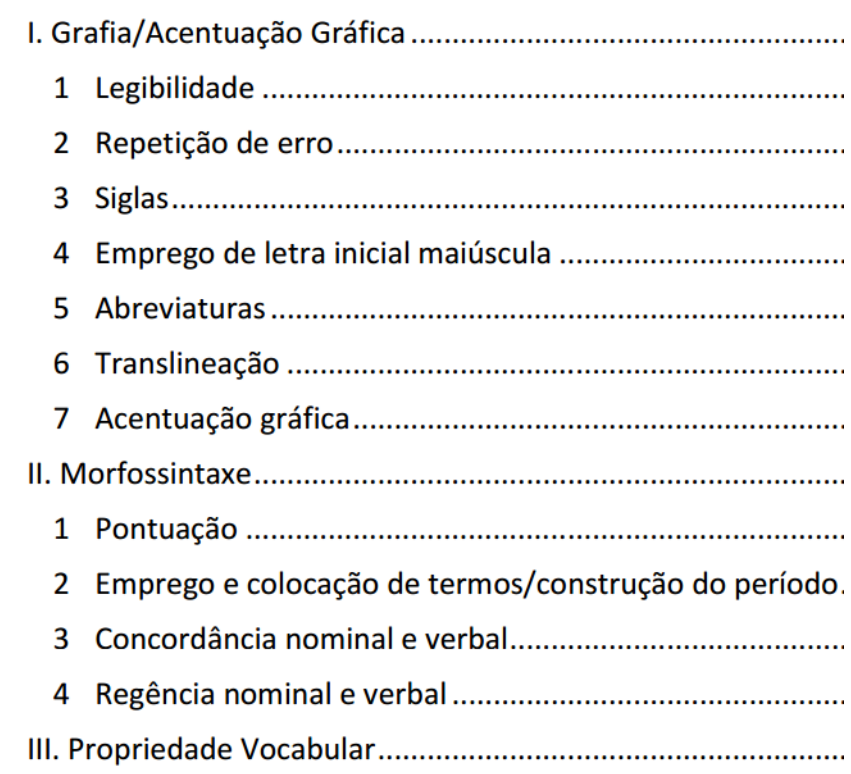

Figura 27 - Critérios de avaliação dos aspectos microestruturais - CEBRASPE.

Dos critérios microestruturais de avaliação, a pontuação foi o que mais influência teve do documento do CEBRASPE. Esse descreve os casos que serão penalizados, caso ocorram nas redações dos candidatos, e os critérios descritos a seguir foram aplicados à tabela de análise dos dados desta pesquisa: 
É registrado como erro o emprego de vírgula ao final de uma declaração (Os softwares utilizados para usufruir do voip também evoluem de forma acelerada, os softwares possibilitam a utilização de recursos de transmissão de voz [...]). Nesse exemplo, identifica-se erro no emprego da vírgula após "acelerada", termo que encerra uma declaração.

É registrada como erro a ausência de vírgula nos casos em que essa pontuação seja necessária para isolar locuções ou expressões adverbiais longas — assim consideradas as expressões com três ou mais palavras — deslocadas, para o início da oração, ou intercaladas.

É registrada como erro a ausência de vírgula no caso de orações adverbiais deslocadas, independentemente da extensão da oração. (CEBRASPE, 2013:6)

Além dos critérios dessas duas grades de correção, ambas aplicadas a avaliações dedicadas a aferir o domínio linguístico escrito de concluintes do Ensino Médio brasileiro, foi necessário, com base nas gramáticas tradicionais, acrescentar alguns critérios e detalhar outros para que se pudesse ter uma noção abrangente dos erros dos alunos de sexto ano ao usarem a língua escrita para se posicionarem sobre algum tema. Ademais, um dos objetivos da pesquisa é verificar se a entonação influencia na organização das frases e parágrafos, o que também justifica a necessidade de se modificar as grades de correção do ENEM e do CEBRASPE.

\subsection{Análise de erros}

A análise de erros é um tipo de análise linguística tradicional na Linguística Aplicada, sobretudo nos estudos de aquisição de língua não materna. Essa prática tem como foco os erros cometidos pelo aprendiz durante o processo de aquisição da língua alvo (a que se está aprendendo), comparando-os com a própria língua alvo. Por isso, esse tipo de análise põe o aprendiz no centro do processo de ensino e (ou) aprendizagem de língua.

Nesse tipo de análise, os erros cometidos pelo aprendiz levam em conta a interferência de sua língua materna sobre a língua alvo. Esse é um fato importante em relação à natureza do erro do aprendiz, porém não é o único que deve ser considerado.

Apesar de ser um tipo de análise linguística desenvolvido para o ensino de língua não materna, é possível aplicar a análise de erros também ao ensino de língua materna. No caso da língua portuguesa, observa-se que, na prática, o aluno tem como língua materna a modalidade falada da língua, que diverge do foco da escola, que é a modalidade escrita. No processo de ensino aprendizagem da língua portuguesa escrita, assim como no ensino de inglês para 
brasileiros, por exemplo, observam-se erros motivados pela língua materna ao se produzir a língua alvo. Assim, um dos principais problemas na produção de textos escritos em língua portuguesa por falantes nativos desse idioma é a interferência da língua falada. Isso causa problemas desde a grafia das palavras até a organização textual. Por essa razão, justifica-se a análise de erros neste estudo.

Vale frisar que a noção de erro é entendida nesta pesquisa como os desvios que os alunos produziram em relação à norma padrão escrita. Dessa forma, considera-se como erro os desvios de grafia das palavras e também de questões sintáticas e morfológicas.

Neste trabalho, analisar os erros dos alunos para se refletir sobre o ensino de produção de textos nas aulas de língua portuguesa e, mais que isso, pensar em interferências didáticas significativas é etapa fundamental. Foi a análise dos erros cometidos pelos estudantes em foco que definiu o desenho desta pesquisa, a partir da seleção e adaptação dos microcritérios que serão trabalhados nos capítulos seguintes.

A análise de erros acabou funcionando como avaliação diagnóstica em sala de aula, e essas foram direcionando as ações seguintes, tanto em sala de aula, quanto nesta pesquisa. Assim, esse processo acabou direcionando a pesquisa para a prática da Pesquisa-Ação. Os erros que os alunos apresentaram em suas produções de texto foram mapeados, organizados e analisados, de forma a direcionar as intervenções didáticas que conduziram às conclusões desta pesquisa. 


\title{
Capítulo 3 - $O$ percurso investigativo
}

\begin{abstract}
A curiosidade, instinto de complexidade infinita, leva por um lado a escutar às portas e por outro a descobrir a América; - mas estes dois impulsos, tão diferentes em dignidade e resultados, brotam ambos de um fundo intrinsecamente precioso, a actividade do espírito. Eça de Queirós
\end{abstract}

'Pesquisar' é uma palavra que tem em si a curiosidade, o desejo de saber mais sobre algo, o instinto próprio ao ser humano de ir além e conhecer mais. As civilizações são hoje, também, o resultado de suas pesquisas, as quais foram empreendidas pela fome de conhecimento, que vem, em movimento contínuo e ininterrupto, gerando descobertas e quebrando barreiras. É assim em todas as áreas do saber, e a Linguística vem sendo terra fértil para a curiosidade de quem sobre ela se debruça.

A evolução do processo comunicativo garante aos estudos sobre a linguagem vasta e longeva fonte de investigação. Ao se inserir a educação nesse campo, amplia-se exponencialmente o desejo de conhecer mais, de investigar as mudanças e adaptações que as interações sociais vêm sofrendo em virtude das mudanças tecnológicas e sociais, proporcionadas pelo século XXI.

Em razão disso, este estudo vem se debruçar sobre a relação entre jovens adolescentes com idade entre 10 e 12 anos e a sistematização em textos escritos daquilo que tão eficazmente já produzem oralmente: a argumentação. Para que se possa investigar essa questão, é preciso lançar o olhar investigativo de forma organizada sobre o fenômeno, coletar dados variados que sustentem ou refutem as hipóteses, já mencionadas no capítulo 1 desta tese, e analisá-los, cuidadosamente. Sendo assim, o presente capítulo tratará da forma como esta pesquisa foi empreendida.

Aqui serão apresentados os fundamentos norteadores e geradores dos dados analisados, além de sua análise e tratamento. É na metodologia que será discutido o percurso investigativo, os caminhos a que os resultados foram conduzindo, a curiosidade - instigadora de mais pesquisa - , que eles foram gerando na pesquisadora e seus consequentes desdobramentos. Assim, a apresentação se inicia com a exposição das indicações metodológicas feitas pela $U B L$, o qual defende que a análise quantitativa pode auxiliar a análise qualitativa, sem haver a necessidade de se aprofundar em aspectos estatísticos. Em seguida, dados relativos aos participantes serão apresentados; assim, é nesse momento que o leitor conhecerá detalhes sobre a escola na qual a pesquisa foi empreendida e sobre os alunos que produziram os dados 
analisados. Logo depois, serão apresentadas informações acerca da composição do corpora de análise, com a formação dos três corpus construídos: questionário, produção de textos e programa de rádio. Por fim, será apresentado como será feita a análise dos dados. Assim, todo o caminho percorrido nesta pesquisa será apresentado ao longo deste capítulo, com as justificativas para a adoção de cada uma das estratégias e instrumentos utilizados.

\subsection{Embasamento teórico}

O presente estudo tem como base teórica e metodológica a Linguística Funcional Centrada no Uso, o que significa realizar análises de cunho qualitativo e quantitativo dos dados. O olhar qualitativo sobre os dados é fundamental para que se possa avaliar a natureza dos fenômenos observados e, assim, verificar como eles agem na argumentação escrita dos alunos. Por outro lado, a análise quantitativa revelará quão recorrentes são os recursos utilizados pelos alunos, quais pontos precisam de maior interferência do professor.

É importante frisar que o cerne da análise é de cunho qualitativo e que a quantificação dos dados é vista apenas como um suporte para as análises, apresentando as tendências identificadas nos dados. Segundo Cezário \& Cunha (2013: 22)

\footnotetext{
O aspecto qualitativo diz respeito ao caráter descritivo e interpretativo da análise e ao enfoque indutivo baseado na observação das amostras coletadas. Já a dimensão quantitativa refere-se à natureza mensurável do material empírico tomado como amostra. Para tanto, quantificamos, em termos absolutos e percentuais, a recorrência dos fatores selecionados para a análise.
}

Assim, a metodologia aqui aplicada tem o suporte teórico da $U B L$, o que justifica o fato de os dados aqui quantificados não terem recebido tratamento estatístico. Sabe-se que os dados aqui analisados representam apenas uma amostra das possíveis ocorrências dos fenômenos enfocados, por isso não são passíveis de avaliações estatísticas, já que essas implicam análises baseadas em bancos de dados mais robustos. Portanto, este trabalho objetiva indicar tendências de uso da língua escrita por alunos do sexto ano. 


\subsection{Os participantes da pesquisa}

Este estudo foi realizado com sessenta e seis alunos do sexto ano, Ensino Fundamental II, com faixa etária entre 10 e 12 anos, de uma escola da rede privada que está localizada em área nobre de Brasília, Distrito Federal. A escolha pelo sexto ano foi feita por se tratar de uma etapa de transição, na qual eles iniciam a segunda etapa do Ensino Fundamental. Esse momento do percurso escolar de um indivíduo é muito importante, pois a base que ele teve até ali é posta em cheque, já que, no sexto ano, há um movimento de ir e vir, no qual os professores apresentam conteúdos fundamentais para o futuro, além de checar e aprofundar o que foi ensinado nas fases iniciais.

A escola em que a pesquisa foi realizada é de tamanho mediano e possui em torno de 900 alunos nos ensinos Fundamental (I e II) e Médio. A clientela dessa escola é formada por pessoas de classe média alta e alta da capital federal (geralmente filhos de políticos, empresários, diplomatas e funcionários públicos de alto escalão) e por filhos de funcionários da escola. Optou-se, aqui, por não divulgar a identidade da escola para a proteção dos participantes da pesquisa e da própria instituição, assim ela será chamada, neste trabalho, de Escola Internacional (EI). Contudo, as características da escola serão apresentadas a seguir.

A escola é internacional e oferece a seus alunos um ensino bilíngue (português e inglês), com os currículos brasileiro e internacional, do ensino infantil ao ensino médio. Seu objetivo é formar cidadãos do mundo, desenvolvendo em cada aluno notáveis qualidades éticas, acadêmicas e espirituais, na busca de pessoas que possam ser agentes transformadores da realidade em qualquer lugar do planeta. A escola propõe um ensino em tempo integral, em que os alunos passam, em média, oito horas do seu dia imersos em ambiente acadêmico. $\mathrm{O}$ ano letivo da escola é organizado em Etapas, equivalentes ao bimestre das escolas brasileiras. Assim, um ano letivo tem quatro etapas, que têm duração entre dois e três meses. Ao final de cada etapa, os alunos são submetidos a avaliações formais escritas, cujas notas comporão a média bimestral de aproveitamento do aluno, em cada disciplina.

A escola segue o calendário americano, o que significa que o ano letivo tem início no final de julho e término na metade de junho. Por ser uma escola internacional, há alunos de várias nacionalidades, sobretudo filhos de funcionários do corpo diplomático de diversos países, que vêm trabalhar em Brasília, porém cerca de $90 \%$ dos alunos é formado por brasileiros. É importante ter em conta que esta pesquisa teve como participantes os alunos do 
currículo brasileiro, que têm o português como língua materna e, por isso, têm seis horas aulas semanais de ensino de língua portuguesa, nas quais se incluem componentes voltados à gramatica, à leitura, à interpretação e à produção de textos. Dentre esses alunos do chamado, pela escola, de ensino regular de língua portuguesa, havia três alunos estrangeiros que estudavam a Língua Portuguesa como materna, embora suas verdadeiras línguas mães fossem a língua inglesa e a língua russa. As produções de textos desses alunos foram analisadas juntamente com as dos brasileiros em razão da proficiência demonstrada pelos alunos ao longo das aulas e das atividades realizadas.

Durante o sexto ano, os alunos estudam, nas disciplinas língua portuguesa e língua inglesa, conteúdos semelhantes, como algumas classes de palavras (verbos, substantivos, adjetivos) e tipos textuais (narração, argumentação e texto expositivo). Na disciplina de língua portuguesa, os alunos aprendem sobre a estruturação formal e discursiva do texto argumentativo, e os mesmos conteúdos são trabalhados em língua inglesa, sob o título de texto persuasivo (persuasive essay).

As aulas de língua portuguesa são ministradas por uma única professora, que trabalha com toda a carga horária da disciplina e leciona gramática, literaturas e produção de texto. A mesma estrutura é adotada na disciplina de língua inglesa, que também tem carga horária de seis horas aula por semana. As duas disciplinas enfocam, no que diz respeito à forma, a organização dos parágrafos e do texto argumentativo, conforme apresentado no capítulo anterior.

\subsection{A construção dos corpora de análise}

Esta pesquisa segue os preceitos da $U B L$, e, por isso, tem como objeto de pesquisa a língua viva, em um contexto de comunicação específico do universo escolar. Não serão analisadas aqui frases isoladas ou criadas para fins de pesquisa. Será investigado como os alunos do sexto ano estão produzindo textos escritos e se estão transpondo para a língua escrita, em texto argumentativo, marcas próprias da oralidade, sobretudo no que diz respeito à organização textual.

Para tanto, foi organizado um corpus composto de três corpora, sendo: 150 produções de textos argumentativos dos alunos, um questionário para compreender a percepção dos alunos 
sobre a organização textual e um áudio para se verificar a relação entre a oralidade e a escrita acerca da pontuação. Assim, será possível dispor de material consistente para refutar ou confirmar as hipóteses levantadas na introdução desta tese.

\subsubsection{Produção de textos argumentativos pelos alunos do sexto ano da Escola Internacional}

O principal corpus desta pesquisa é constituído por 150 produções de textos argumentativos, desenvolvidas pelos alunos nas avaliações da primeira, da segunda e da terceira etapas. Foram avaliadas apenas a primeira versão de cada produção, tendo em vista que, após a correção dos textos, cada aluno reescreveu sua produção com base na correção do professor (contudo esse exercício não contava como nota para a avaliação de redação). Como o escopo do trabalho é identificar os erros que os alunos cometem ao utilizarem a língua, não foi considerada a segunda versão, já que essa apresentaria a interferência do professor.

A docente das turmas analisadas optou por trabalhar, desde as primeiras semanas do ano letivo, com o texto argumentativo. Ela optou por provocar discussões orais dos grupos, a partir de temas suscitados pelos livros paradidáticos lidos pelas três turmas. $\mathrm{O}$ primeiro dizia respeito ao uso da informática em sala de aula, principalmente do computador e do tablet. Antes mesmo da leitura do livro ser finalizada pelos alunos, o tema começou a ser trabalhado, com pesquisas acerca do assunto e com os alunos buscando a opinião de seus responsáveis sobre o tema. Com o avançar da leitura do livro, as discussões em sala de aula foram ficando mais frequentes, e, ao final desse ciclo de trabalho, foi realizado um debate oral, em que a turma se organizava em dois grupos, um que deveria defender o uso da informática em sala de aula, e outro que deveria defender o não uso dessas tecnologias no espaço escolar.

Para se prepararem para o debate, os alunos precisaram procurar argumentos, além de separar os que constavam no livro "Meu computador, a internet e eu", adotado como paradidático para o sexto ano. Durante o debate, cada membro do grupo tinha três minutos para apresentar seus argumentos. Ao final da fala de cada um, a palavra era passada para o grupo opositor. O objetivo do debate era convencer a plateia, formada por colegas de classe, de seus argumentos. Em cada uma das três turmas, os argumentos e os resultados foram diferentes, e a atividade evidenciou que defender um ponto de vista, para esses alunos, não era uma atividade 
distante de suas realidades, ao contrário, eles estavam bastante familiarizados com o ato de argumentar.

Após debate oral, os alunos precisaram escrever a discussão, produzindo, então, um texto dissertativo-argumentativo, nos quais deveriam atender à seguinte proposta de produção.

\footnotetext{
Primeira proposta de produção de texto argumentativo do ano letivo 2014/2015: Nas duas primeiras semanas de aula, conversamos e lemos sobre o uso da tecnologia em nossas vidas, especialmente na sala de aula.
}

Agora é hora de você escrever um pouco sobre isso. Você é contra ou a favor da presença da tecnologia em nossas vidas? Por quê?

Faça um texto, apresentando seu ponto de vista sobre o tema. Para seu texto ficar ainda mais interessante, use exemplos e histórias apresentadas no livro "Meu computador a internet e Eu!". Seu texto tem que ter no mínimo 20 e no máximo 30 linhas.

Antes da produção do texto, o conceito de texto dissertativo foi trabalhado, e, também, a noção de parágrafo argumentativo. Em virtude da abstração do conceito de parágrafo e da carência de informações sobre isso no material didático, foi apresentada uma fórmula, um modelo de parágrafo que deveria ser seguido pelos alunos: o parágrafo deveria ter pelo menos duas frases, tratar de um assunto apenas e ter entre cinco e oito linhas. Os resultados dessa primeira produção também foram analisados e compõem o corpus deste trabalho.

O trabalho com a produção de texto argumentativo continuou ao longo da primeira Etapa, com leitura e analise de textos dessa tipologia, com ênfase na organização textual, além da reescrita das produções dos alunos. Esses procedimentos foram realizados antes da avaliação da primeira etapa.

A produção de textos compõe a prova de Língua Portuguesa na EI. A docente do sexto ano optou por solicitar aos alunos a elaboração, para a avaliação bimestral, de um texto argumentativo, com base na leitura do livro paradidático "Yakima, o menino onça", do escritor Francisco de Assis Brasil. Esse foi indicado como leitura no mês de setembro, época em que foram realizadas as avaliações da primeira etapa, cuja temática está relacionada aos índios no Brasil. Os resultados dos trabalhos dos alunos atenderam às expectativas da primeira Etapa do ano letivo, início do trabalho com paragrafação e texto argumentativo. 
Além do trabalho prévio com a tipologia, os temas abordados nessas redações foram previamente discutidos com os estudantes, para que eles pudessem apresentar e defender seus pontos de vista de forma consistente e adequada ao sexto ano. Durante o processo de aprimoramento das produções de texto, foram trabalhados diversos pontos que serão abordados na análise dos dados, sobretudo na comparação da organização textual escrita com a organização textual falada. O trabalho desenvolvido em sala influenciou diretamente nos resultados aqui demonstrados.

Retornando-se ao foco sobre os temas propostos nos dados analisados, conforme mencionado no parágrafo anterior, os alunos foram expostos a discussões e outras atividades sobre os assuntos ante os quais eles deveriam se posicionar. Essa estratégia foi adotada com a intenção de os alunos chegarem para a avaliação com menos ansiedade para a produção de texto, e pudessem, então, apresentar o melhor desempenho possível, já que essa etapa da avaliação não lhes causaria surpresas.

- Etapa 01

Proposta: Com base nas atividades feitas em sala, na leitura do livro "Yakima, o meninoonça" e nos textos desta avaliação, escreva um texto, apresentando sua opinião sobre o tema:

"Índios no Brasil: quem são, como vivem, que línguas falam e por que merecem a atenção dos governantes e da sociedade".

Seu texto deverá ter no mínimo 20 e no máximo 30 linhas

- Etapa 02

Proposta: Temos, abaixo, um cartaz sobre a leitura. Com base nas informações nele contidas e nos textos 01 e 02 de nossa avaliação, reflita: qual é a importância da leitura para a formação do ser humano?

Responda a essa pergunta, apresentando sua opinião sobre o tema, em um texto de, NO MÍNIMO, 20 linhas. Não deixe de apresentar seu ponto de vista, com justificativas e exemplos, além de sua opinião.

- Etapa 03

Proposta: Ao longo do bimestre, fizemos a leitura de "Não se esqueçam da rosa", livro de Gisela Nicolelis. Agora, você produzirá um texto, fazendo uma crítica ao livro. 
Dentre as propostas apresentadas, uma delas merece explicação especial. O tema proposto para o terceiro bimestre é relativo à leitura de um livro com o qual todos os alunos trabalharam. A narrativa conta a história de uma menina da idade dos alunos (12 anos), que descobre ser portadora de uma doença que degenera seus ossos. Esse problema é genético e ela herdou de seu pai, um sobrevivente da bomba atômica de Hiroshima. Durante o trabalho com "Não se esqueçam da rosa", foram realizadas pesquisas temáticas e rodas de debates sobre os assuntos enfocados na narrativa, além de pequenos textos sobre esses momentos de reflexão coletiva. Os alunos, das três turmas de sexto ano, se engajaram nas atividades propostas e, sobretudo, com a temática em si. Por sugestão de um dos alunos, foi feita a análise da poesia "Rosa de Hiroshima", de Vinícius de Moraes, sempre com a intensa participação de toda a turma. Depois de todo o percurso de conhecimento do assunto, os alunos foram convidados a se posicionar, por escrito, sobre o livro e sobre os acontecimentos históricos que o permearam. Esse, então, foi o momento final de uma série de atividades embasadas em "Não se esqueçam da rosa".

Os alunos do Ensino Fundamental II da Escola Internacional realizam frequentes produções de texto, com ênfase no tipo argumentativo. O processo de elaboração de seus textos inclui a escrita e a reescrita de seus textos, de forma que, semanalmente, eles realizam tarefas relacionadas à prática textual.

Os temas abordados nas produções de texto são, anteriormente, pesquisados pelos alunos e trabalhados pelo professor durante as aulas, para que haja riqueza de argumentos, considerando a faixa etária em análise. Dessa forma, percebe-se que o aluno tem que se preocupar com a qualidade de argumentos, além da estrutura de sua produção de texto. A metodologia trabalhada em relação à produção de textos teve como objetivo oferecer ferramentas para o aluno, desde o início do Ensino Fundamental II, para que ele pudesse transitar, sem grandes dificuldades, pelas tarefas que o meio acadêmico irá lhe cobrar, com trabalhos cada vez mais complexos, os quais exigirão posicionamento crítico e reflexivo do estudante. 


\subsubsection{Questionário - Instrumento de pesquisa e constituição de corpus I}

O questionário ${ }^{38}$ é, segundo Marconi \& Lakatos (2003: 200), um instrumento de coleta de dados em que se obtém um grande número de informações, com qualidade e maior uniformidade, devido à pouca influência do pesquisador sobre a resposta do informante. Nesta pesquisa, optamos por utilizar o questionário como mais uma fonte de dados, pois, por meio dele, buscamos verificar em que medida o aluno de sexto ano tem consciência dos conhecimentos acionados por ele durante a produção de um texto argumentativo. Assim, os resultados aqui funcionaram como acessórios para a análise das produções de texto, que são o foco neste estudo.

As perguntas formuladas ao longo do questionário são dos seguintes tipos:

- abertas ( questões 03, 04, 05, 08, 09 e 10) - permitem aos alunos apresentarem livremente sua opinião acerca dos conceitos investigados;

- fechadas e dicotômicas (questão 01) - investigam hábitos dos alunos de forma objetiva e obtêm respostas negativas ou afirmativas;

- fechadas e de múltipla escolha (questão 02) - investigam os conhecimentos dos alunos sobre a organização textual de forma objetiva, com uma série de possíveis respostas que exploram várias facetas do tema em cheque; $\mathrm{e}$

- mistas (questões 06, 07 e 11) - conjugam as questões abertas e fechadas, solicitando maior reflexão dos alunos, além de suas justificativas para as alternativas escolhidas.

A ordem das perguntas foi pensada considerando os ensinamentos de Marconi \& Lakatos (2003: 210), que instruem a se iniciar o questionário com perguntas mais simples e gerais, para depois seguir as "questões de fato", aquelas que são o cerne da pesquisa. Assim, iniciamos o instrumento com uma pergunta objetiva sobre hábitos do informante. A complexidade das perguntas aumenta conforme o desenrolar do questionário, e culmina em um convite para que o aluno produza um pequeno texto argumentativo. Nesse momento, o objetivo é verificar se há correlação entre o que eles pensam e o que fazem ao redigir.

O uso de questionários possibilita que os dados obtidos sejam textuais. Ou seja, os informantes produzem textos - escritos, no caso desta pesquisa - , que são base da pesquisa

\footnotetext{
${ }^{38}$ Vale ressaltar que o instrumento utilizado neste trabalho se encontra no Anexo 1.
} 
qualitativa. Günther (2006: 202) ensina que "a pesquisa qualitativa é uma ciência baseada em textos, ou seja, a coleta de dados produz textos que nas diferentes técnicas analíticas são interpretados hermeneuticamente". Assim, um mesmo instrumento atende aos critérios da pesquisa qualitativa e forma um banco de dados rico em material linguístico para ser analisado, que também pode ser quantificado, a depender do desenho da pesquisa realizada. As respostas dos alunos foram submetidas à mesma análise e levantamento de erros que as produções de textos, porém seus resultados foram apresentados e analisados separadamente.

No instrumento em foco, buscou-se verificar em que medida o que é ensinado durante as aulas de língua portuguesa - sobre organização do texto argumentativo - se relaciona com as regras subjacentes à produção de fala e escrita. Tentou-se verificar se há, nos alunos, a consciência dos conceitos relativos à paragrafação e à pontuação, elementos importantes para a organização do texto escrito, e sua aplicação durante a produção textual. Sabe-se que o conteúdo relativo à organização textual é trabalhado durante as aulas de língua portuguesa, mas fica a dúvida se o processo de produzir um texto é regido pelas técnicas trabalhadas em sala ou pela ideia de texto que os alunos trazem consigo. Além disso, procuramos verificar se eles julgam haver relação entre a organização textual escrita com a falada.

Outra razão que demonstra a importância dos dados gerados pelo questionário é a necessidade de se saber que noções de organização textual - e de texto - o aluno do sexto ano tem. Isso porque o aluno, na transição do Ensino Fundamental I para o Ensino Fundamental II, ainda está muito ligado a elementos concretos. Assim, se a noção de texto e organização textual for, para ele, totalmente abstrata, aplicar a teoria às suas produções de texto torna-se um processo ainda mais complexo. Nesse aspecto, as perguntas elaboradas no instrumento buscaram mensurar o nível de compreensão dos alunos sobre texto e organização textual.

Após a aplicação do questionário a 41 alunos (quantidade de alunos que estavam presente na aula no dia da aplicação do instrumento), as respostas às perguntas fechadas e mistas foram catalogadas, quantificadas e analisadas. Já as das perguntas abertas, foram integralmente copiadas, com problemas formais preservados, e analisadas. A versão completa do questionário está em Anexo 1. Todas as etapas executadas geraram gráficos e informações que serão apresentados no próximo capítulo. 


\subsection{O corpus II}

O corpus II, formado pela produção de texto dos alunos, foi analisado com base em uma tabela organizada com cinco macrocritérios, subdivididos em vinte e oito aspectos microestruturais de análise. Esses foram inspirados nas matrizes de correção de redação, utilizadas no Exame Nacional do Ensino Médio (ENEM) ${ }^{39}$ e pelo Centro Brasileiro de Pesquisa em Avaliação e Seleção e de Promoção de Eventos (CEBRASPE), para a correção de redações e questões dissertativas ${ }^{40}$.

A decisão de inspirar os critérios de análise deste estudo em matrizes de correção de redações de avaliações de larga escala aponta para uma perspectiva teórica diversa do Funcionalismo. Os critérios microestruturais de avaliação das produções de texto se pautam na gramática normativa da língua portuguesa, em sua variedade padrão, na qual se privilegia a estrutura formal em detrimento ao uso. Aqui não se considera essa decisão metodológica como conflito de teorias, já que o critério usado pela sociedade para avaliar o conhecimento de um indivíduo sobre sua competência no uso formal da língua portuguesa é a proximidade ou afastamento da produção textual escrita ou oral, com a norma padrão.

Inicialmente, delimitou-se os cinco eixos de investigação: (i) Escrita Formal, (ii) Tipologia e Proposta, (iii) Paragrafação, (iv) Coesão e (v) Pontuação. Essa definição foi fundamental para este trabalho, pois explicitou o caráter formal que a ele se pretende dar, já que a qualidade da argumentação não faz parte de seu escopo. Nesse âmbito, é importante retornar aos princípios teóricos da $U B L$, a fim de justificar a escolha aqui feita. Acredita-se que um dos caminhos para uma intervenção didática eficaz é a real noção das dificuldades dos alunos, e, nesse caso, verificar a gramática que eles empregam em seus textos escritos é o ponto inicial. Somente a partir desse ponto é possível intervir no uso da língua escrita, para adequá-la, o máximo possível, ao contexto acadêmico.

Chegar ao modelo de grade de correção utilizado não foi uma tarefa simples, pois sua elaboração não foi baseada somente na mescla dos modelos selecionados (ENEM e CEBRASPE). Foi preciso, também, adequá-las aos dados, o que só foi possível na medida em

\footnotetext{
${ }^{39}$ Disponível em http://download.inep.gov.br/educacao_basica/enem/guia_participante/2013/guia_de_redacao_enem_2013.pdf

${ }^{40}$ Disponível http://www.cespe.unb.br/vestibular/vestunb_13_1/arquivos/CRIT_RIOS_ADOTADOS_NA_AVALIA__O_ DE_ASPECTOS_MICROESTRUTURAIS.PDF
} 
que a correção foi progredindo. Porém, refazer os critérios de correção a cada novo texto lido demandou o retrabalho de analisar, mais uma vez, os textos já analisados. Assim, optou-se por se fazer uma pré-testagem, ou uma pré-correção, com trinta textos para poder refinar a grade de correção que seria aplicada a todos os dados.

A seguir, o quadro completo de critérios de análise das produções dos alunos, que também consta no Anexo 03. Nele é possível observar os macrocritérios e os relacionados à microestrutura. Sua frequência de ocorrência será apresentada na sequência.

\begin{tabular}{|c|c|}
\hline & Escrita formal \\
\hline & 1a) Acentuação \\
\hline & 1b) Concordância Nominal \\
\hline & 1b) Concordância Verbal \\
\hline & 1c) Ortografia \\
\hline & Tipologia e Proposta \\
\hline & Paragrafação \\
\hline & 3a) Texto formado por um parágrafo. \\
\hline & 3b) Parágrafo composto por uma só frase. \\
\hline & 3c) Parágrafo composto por frases longas. \\
\hline & $\begin{array}{l}\text { 3d) Parágrafo com mais de uma ideia sendo } \\
\text { desenvolvida. }\end{array}$ \\
\hline & Coesão \\
\hline & 4a) Uso inadequado de conectivos. \\
\hline & 4b) Uso inadequado de tempos verbais. \\
\hline & 4c) Truncamento de informações \\
\hline & 4d) Repetição de palavras. \\
\hline & 4e) Colocação pronominal (obliquos). \\
\hline & $\begin{array}{l}\text { 4f) Regência - nominal e verbal (uso do } \\
\text { acento indicativo de crase). }\end{array}$ \\
\hline & $\begin{array}{l}4 \mathrm{~g}) \text { Uso de "coisa" como elemento de } \\
\text { retomada. }\end{array}$ \\
\hline & $\begin{array}{l}\text { 4i) uso de termos de referência sem } \\
\text { antecedente determinado. }\end{array}$ \\
\hline & Pontuação \\
\hline & 5a) Uso de virgula entre sujeito e verbo. \\
\hline & 5b) Uso de virgula entre verbo e objetos. \\
\hline & $\begin{array}{l}\text { 5c) Ausência de vírgula para isolar orações, } \\
\text { locuções ou expressões adverbiais deslocadas. }\end{array}$ \\
\hline & $\begin{array}{l}\text { 5d) Ausência de virgulas entre orações e } \\
\text { termos intercalados. }\end{array}$ \\
\hline & $\begin{array}{l}\text { 5e) Ausência de vírgulas antes de orações } \\
\text { subordinadas. }\end{array}$ \\
\hline & $\begin{array}{l}\text { 5f) Ausência de virgulas em frases com } \\
\text { alteração de sujeito. }\end{array}$ \\
\hline & $\begin{array}{l}5 \mathrm{~g}) \text { Ausência de vírgula antes de "mas", } \\
\text { "porém" etc. em coordenação sindética. }\end{array}$ \\
\hline & $\begin{array}{l}\text { 5h) Ausência de ponto final após declaração } \\
\text { inicial. }\end{array}$ \\
\hline & $\begin{array}{l}\text { 5i) Uso de virgula antes de último item de } \\
\text { enumeração de itens simples (ex: usa, mặă, banana). }\end{array}$ \\
\hline & $\begin{array}{l}\text { 5j) Ausência de vírgula antes de oração de } \\
\text { valor explicativo. }\end{array}$ \\
\hline & $\begin{array}{l}\text { 5k) Ausência de vírgulas antes de orações } \\
\text { coordenadas alternativas. }\end{array}$ \\
\hline
\end{tabular}

Figura 28 - Critérios de avaliação dos dados 
Para a análise, foi considerada a frequência com que os problemas ocorreram nos textos, desde que em contextos distintos. Por exemplo: o erro de regência foi computado mais de uma vez em um único texto se ele ocorresse com verbos e/ou nomes diferentes, caso o erro de regência ocorresse mais de uma vez no texto, com o mesmo verbo, o problema era computado apenas uma vez.

A análise realizada parte da quantificação da ocorrência dos aspectos observados no corpus. Contudo, é necessário enfatizar que não há, nesta pesquisa, a intenção de gerar dados estatísticos a partir dos resultados, já que, para tal, seria necessário ampliar o quantitativo de textos analisados. A partir da quantificação dos dados, foi possível delimitar os aspectos que seriam, aqui, analisados mais detidamente. Em termos numéricos gerais, o gráfico a seguir apresenta o quantitativo de ocorrência dos problemas relacionados à estrutura formal da língua.

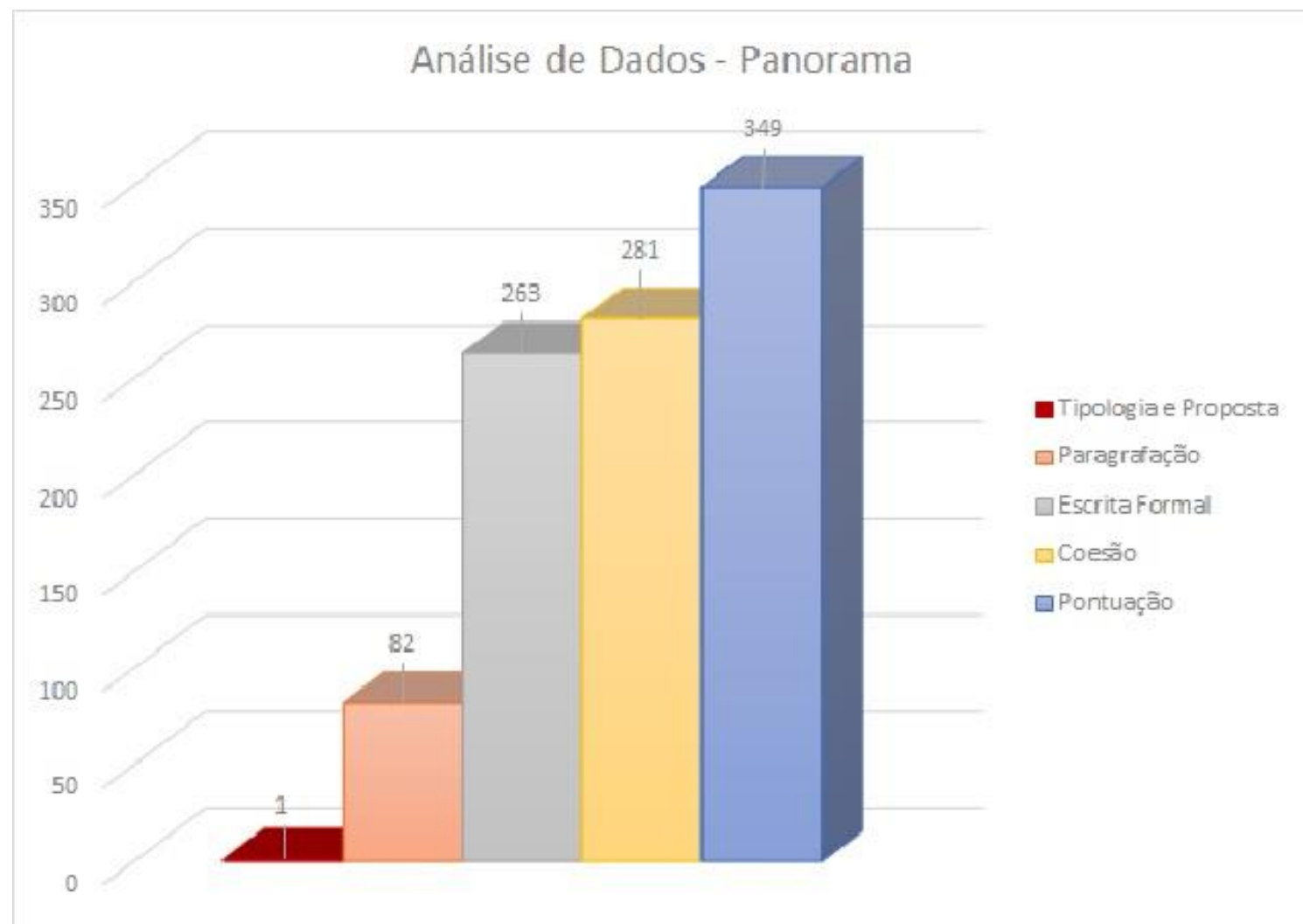

Gráfico 1 - Panorama da análise de dados

$\mathrm{Na}$ representação acima, é possível verificar que, em 150 produções de textos analisadas, houve 976 erros, na soma dos erros de todos os microcritérios. Desses, 349 foram relativos à pontuação, 281 à coesão, 263 à escrita formal, 81 à paragrafação e apenas um problema relativo à tipologia e ao atendimento à proposta. Essa foi a primeira quebra de expectativas em relação aos dados, pois, por se tratar de alunos do sexto ano, mesmo com o 
trabalho desenvolvido ao longo das aulas, era esperado que alguns não atendessem aos comandos do enunciado, ou usassem o tema para desenvolver narrativas, tipologia trabalhada nos anos anteriores e, por isso, mais familiar ao grupo. Essa expectativa foi criada com base na experiência docente da pesquisadora, quando trabalhou com outros grupos, também de sexto ano, da Escola Internacional.

Entende-se que é na proposta de produção que a intencionalidade da redação será explicitada e que os interlocutores serão definidos, e isso delimita o grau de formalidade com que deve ser escrito o texto. A ocorrência de apenas um caso, relativo a Tipologia e Proposta, indicia que as atividades prévias de sensibilização e análise de textos argumentativos foram positivamente recebidas pelos alunos, que aplicaram seu conhecimento nas avaliações que fizeram.

Outro macrocritério analisado, cujos resultados divergiram do esperado, foi o que diz respeito à paragrafação. Logo nas primeiras atividades realizadas, no início do ano letivo de 2014/2015, os alunos das três turmas produziam textos com problemas de paragrafação, conforme será apresentado mais adiante. Era comum que os alunos produzissem parágrafos formados por uma frase longa, composta de mais de dois períodos, ou que organizassem o texto inteiro com um único, e exaustivo, parágrafo. Contudo, como o gráfico acima indica, apenas 82 problemas detectados foram relativos a esse macrocritério.

No que diz respeito à coesão e à pontuação, os dados, quantitativamente, confirmaram a suposição inicial de que ambas seriam parte sensível na produção de texto argumentativo na faixa etária em foco. Porém, qualitativamente, os aspectos microestruturais mais sensíveis também romperam com o esperado. Como a hipótese principal desta tese é que a entonação influencia diretamente a organização sintática do texto escrito, era esperado, por exemplo, que a presença de vírgula entre verbo e sujeito, em relação à pontuação, fosse recorrente nos dados; porém outros usos da vírgula se revelaram mais produtivos, o que lançou luz sobre novas perspectivas de análise do fenômeno em foco.

Em relação à escrita formal, dados e expectativa caminharam juntos, quantitativamente, pois a ocorrência de problemas nesse macrocritério foi coerente ao período de início do Ensino Fundamental II. Contudo, a natureza dos erros indica que a relação fala e escrita ainda está muito latente, além da influência da tecnologia, questões que terão sua discussão aprofundada mais adiante.

Após a primeira organização em relação à natureza dos erros, cada microcritério delimitado teve seus dados analisados à luz de estudos na área, mencionados no capítulo 01 
desta tese. Em relação ao macrocritério Escrita Formal, os microcritério Ortografia foi estudado com base no que ensina Lemle (2011) acerca da relação letra e som. Ainda sobre a relação fala e escrita, estudos de Tenani (2011) subsidiam a análise acerca de hipo e hipersegmentação.

\subsection{O olhar sobre os dados}

Mais importante do que ter um grupo de dados para se analisar é como esses dados são observados pelo pesquisador. Dessa forma, 150 redações de alunos do sexto ano podem representar o quantitativo de trabalho extra sala de aula que um professor tem, ou pode ser uma fonte rica de pesquisa linguística acerca do uso da língua.

O trabalho que está sendo aqui apresentado indica que o olhar escolhido sobre os textos em questão foi o segundo, e essa escolha implicou desdobramentos. A primeira decisão a se tomar envolvia a natureza dos textos que seriam investigados. Inicialmente, a ideia de se elaborar uma proposta de produção de texto para ser aplicada com o único objetivo de servir a esta pesquisa foi cogitada. Contudo, os dados refletiriam o resultado de um momento pontual no percurso escolar dos alunos, e poderia não apresentar diversidade de estruturas a serem analisadas, tampouco o quantitativo de textos que, de fato, foram investigados.

Após leituras acerca da pesquisa e diálogo com a coordenação da escola, optou-se por se constituir um banco de dados linguísticos a partir das produções dos alunos em três momentos distintos do ano letivo. Essa decisão teve implicações de várias formas: (i) os textos precisariam ser digitalizados e armazenados antes de corrigidos; (ii) a escola precisava atuar como parceira nas atividades; e (iv) a análise precisaria ser, além de dados científicos para este estudo, fonte de dados para ajustes pedagógicos em relação aos alunos.

Vencidas as etapas descritas, era preciso delimitar os critérios de análise, pois esses guiariam a correção dos textos e a configuração deste estudo. Assim, a partir de estudos acerca das matrizes de correção de redação e questões discursivas do ENEM e do CEBRASPE, iniciou-se o processo de delimitar os microcritérios de análise, testar se esses seriam apropriados aos dados e o que se precisava adaptar, como já foi mencionado.

Durante o processo de análise dos dados, alguns resultados indicavam a necessidade de subsídios de outra natureza, ou seja, seria necessário obter mais informações para se tentar realizar uma análise diferenciada e melhor estruturada dos aspectos que se objetivava 
investigar: a organização textual. Com isso, optou-se por dar voz aos participantes da pesquisa e, através de questionário, obter informações sobre como os alunos do sexto ano percebiam alguns conceitos, inerentes à produção de textos. Essa foi uma decisão essencial para este estudo, pois, a partir dos dados fornecidos pelos questionários, foi possível encontrar pistas importantes sobre a relação entre textos orais e escritos e a organização de cada um deles.

Com os dois corpora definidos e coletados, veio a decisão teórico-metodológica de se olhar os desvios à norma padrão da língua a partir da natureza dos erros. Essa é uma indicação própria dos estudos relativos à análise de erros, desenvolvida para o ensino de L2, que se adequou a este estudo. Assim os erros foram categorizados (tabela de análise), organizados de acordo com cada critério definido e analisados a partir desses procedimentos de pesquisa.

Por fim, como a pesquisa relaciona a organização textual em textos escritos e falados, percebeu-se a necessidade de compará-los. Isso ficou latente durante a análise do macrocritério Pontuação. Assim, um áudio de fala espontânea, porém controlada, foi selecionado, transcrito e analisado acusticamente no programa PRAAT. Maiores informações sobre áudio e análise serão fornecidas mais adiante.

Ao longo do caminho, transformou-se metal bruto (provas de redação) em pedras preciosas, que resultaram em joias para o ensino de produção de texto em língua portuguesa. Assim, a partir dessas análises, propõem-se intervenções pedagógicas que possam colaborar para um ensino de língua mais efetivo, que colabora para a função da educação de formar cidadão críticos, aptos e engajados em práticas sociais político-cidadãs.

\subsubsection{Corpus III - análise acústica de áudio e sua comparação com dados do corpus II}

Analisar o texto escrito, e nele buscar elementos da oralidade, traz a curiosidade de extrapolar os pressupostos teóricos e verificar, in loco, as questões investigadas. Assim, decidiu-se verificar a relação entre a quebra entonacional na oralidade com os microcritérios selecionados para a análise da pontuação no texto escrito. Essa análise tem o objetivo de ser mais um elemento que subsidie e justifique os resultados obtidos e as análises feitas acerca do uso da língua escrita pelos alunos de sexto ano.

É importante enfatizar que a análise proposta não é um estudo aprofundado da entonação, por isso não se pretende verticalizar o olhar sobre os dados acústicos aqui apresentados. Sabe-se que para um estudo acústico há a necessidade de um quantitativo maior 
de dados orais, formando um banco de dados representativo, o que não é o caso deste estudo. Aqui, pretende-se analisar apenas uma amostra de texto oral. A análise feita ilustrará, com dados da fala, o uso de determinadas estruturas, a fim de se comparar os ensinamentos de gramáticas tradicionais e o uso da língua na oralidade.

Na verdade, trata-se de um experimento que busca, por meio da representação gráfica de dados acústicos, identificar se há quebra entonacional, ou pausa, entre os elementos que, sintaticamente, necessitam de vírgulas no texto escrito. Portanto, o interesse dessa análise são as pausas, indicadas sob a rubrica [quebra ent.] ou QE. Além dessa marcação, os dados apresentarão a indicação, por meio de um asterisco, da sílaba mais proeminente da sentença, apenas a título de informação, pois isso não está em foco nesta análise.

Analisar um texto veiculado na internet, como é o caso do áudio em análise, foi uma opção metodológica importante e baseada nos critérios do comitê de ética em pesquisa científica. A proposta inicial era gravar os dados de fala dos próprios alunos e analisá-los à luz das teorias aqui trabalhadas. Contudo, esse tipo de prática necessitaria de uma autorização por escrito dos pais e responsáveis por cada aluno das turmas analisadas. Isso poderia ser uma pedra no caminho do andamento da pesquisa. Assim, decidiu-se que a solução mais eficaz seria recorrer a textos disponibilizados na internet.

\section{O experimento}

Em virtude das especificidades da análise acústica, sobretudo em relação à qualidade de áudio, optou-se por fazer a seleção de um quadro de programa de rádio, que fosse produzido em um contexto formal, com fala espontânea. Por isso, decidiu-se buscar uma coluna que fosse ao ar na rádio $\mathrm{CBN}$ e estivesse disponível, gratuitamente, na rede mundial de computadores, para audição e download. Além disso, era necessário que fosse um texto que tivesse argumentação em sua construção (já que os textos escritos analisados têm essa tipologia em sua construção), e que tivesse curta duração, dois minutos, no máximo.

Com base nas características necessárias, optou-se por analisar a coluna diária "Caderninho da Bel”, que vai ao ar às seis horas e cinquenta e sete minutos. Nela, a empreendedora Bel Pesci compartilha com o público algumas de suas anotações pessoais, que colaboraram para seu sucesso. O áudio selecionado, cujo título é "Limpe sua mente", foi ao ar 
no dia onze de setembro de 2015, e pode ser encontrado tanto na página da rádio CBN, quando em seu canal no YouTube $e^{41}$.

Após selecionado, foi feito o download do áudio, em extensão .wav (escolha feita em razão das características do programa de análise), por meio do programa aTube Catcher ${ }^{42}$. Em seguida, o arquivo foi transcrito, grafematicamente. A partir da transcrição do áudio, foi possível identificar as sentenças e as categorias que seriam submetidas à análise acústica. Isso foi possível com o uso do programa PRAAT ${ }^{43}$.

O áudio, com duração original de dois minutos e cinquenta segundos, foi editado, no próprio programa PRAAT, transcrito em editor de texto e, finalmente analisado, acusticamente. Como o programa só analisa trechos de, no máximo, dez segundos, foi necessário segmentar a gravação, em partes que equivaleriam a sentenças que contivessem os elementos de interesse desta pesquisa. A transcrição do áudio é apresentada a seguir.

\begin{tabular}{|l|l|}
\hline \multicolumn{2}{|c|}{ Caderninho da Bel - Limpe sua mente. 11 de setembro de 2015} \\
\hline Hamilton & Muito bom dia para você, Bel Pesci. \\
\hline Bel Pesci & Bom dia, Hamilton, e bom dia, ouvintes. \\
\hline Hamilton & $\begin{array}{l}\text { Hoje é sexta-feira, dia de abrirmos o seu caderno no capítulo "Desafio", } \\
\text { e nós vamos falar da importância de se fazer uma limpeza. Semana } \\
\text { passada, foi uma organização no ambiente de trabalho. Hoje você está } \\
\text { propondo limpeza aonde? }\end{array}$ \\
\hline Bel Pesci & $\begin{array}{l}\text { Uma limpeza mental. Eu vou explicar isso um pouquinho melhor. A gente } \\
\text { comentou, recentemente, no Desafio do Caderninho, que a limpeza ou a } \\
\text { organização do seu ambiente acabam influenciando na organização dos } \\
\text { seus pensamentos também. Você, em um ambiente organizado, leva para } \\
\text { que tudo seja mais organizado. E eu queria falar um pouquinho de uma } \\
\text { limpeza muito importante que às vezes a gente deixa de lado, que é a } \\
\text { limpeza da sua mente. É o seguinte: existem diversos pensamentos que, } \\
\text { às vezes, ficam tomando nossa cabeça, e pode ser alguma pessoa que te } \\
\text { magoou, e aquilo volta para a sua cabeça, ou pode ser algo que não foi }\end{array}$ \\
\hline
\end{tabular}

\footnotetext{
41 Áudio disponível em https://www.youtube.com/watch?v=9jcF969SU3s $\quad$ e em http://cbn.globoradio.globo.com/comentaristas/bel-pesce/BEL-PESCE.htm ambos foram acessados em $11 \mathrm{de}$ setembro de 2015.

${ }^{42}$ Programa disponível para download em http://www.atube.me/video/.

${ }^{43}$ Software para análise de voz desenvolvido por Paul Boersma e David Weenick, disponível gratuitamente nas páginas www.praat.org. e http://www.fon.hum.uva.nl/praat/download_win.html
} 


\begin{tabular}{|c|c|}
\hline & $\begin{array}{l}\text { finalizado, e você quer finalizar aquilo melhor, ou pode ser um problema } \\
\text { que está rolando no trabalho e que ainda não teve solução. Eu convido } \\
\text { vocês a analisar quais são esses pensamentos que, constantemente, tomam } \\
\text { a sua cabeça e, de uma certa forma, solucionar o que dá para solucionar, } \\
\text { ou, pelo menos, tomar um passo diante daqueles que não têm solução total } \\
\text { agora. Vamos dar um exemplo, vai, alguma coisa que está te magoando, } \\
\text { te magoando, te magoando, pode ser... Se foi alguém que fez um erro, } \\
\text { perdoa logo, ou, se não dá para perdoar, marca logo uma conversa. Toma } \\
\text { alguma atitude, para que aquilo que está virando uma repetição na sua } \\
\text { cabeça, possa não ficar matutando na sua cabeça como está fazendo. }\end{array}$ \\
\hline Hamilton & $\begin{array}{l}\text { Tomando espaço do seu tempo, da sua preocupação... atrapalhando a sua } \\
\text { vida... }\end{array}$ \\
\hline Bel Pesci & $\begin{array}{l}\text { Exato. E se for algumas daquelas coisas que não têm solução, tenta } \\
\text { finalizar de alguma forma esse assunto também, porque esses } \\
\text { pensamentos ficam voltando, e porque algumas vezes são pensamentos } \\
\text { negativos ou pensamentos de frustração, de mágoa, também fazem muito } \\
\text { mal. Então quero convidar vocês a fazerem uma limpeza na sua mente, } \\
\text { identificar quais são aqueles pensamentos que não estão fazendo tão bem. } \\
\text { Ou situações que ficam voltando toda hora sem serem resolvidas e, ou dar } \\
\text { um passo adiante de ela estar resolvida ou finalizar. }\end{array}$ \\
\hline Hamilton & $\begin{array}{l}\text { Até porque, como diziam os mais antigos, o que não tem remédio, } \\
\text { remediado está. }\end{array}$ \\
\hline
\end{tabular}

Tabela 4 - Transcrição de áudio "Caderninho da Bel".

A transcrição do áudio é fundamental para identificar os trechos que devem ser analisados no programa de análise acústica. A seleção foi feita com base nos microcritérios que compõem o macrocritério Pontuação de análise dos dados. Nesse, os desvios da norma padrão foram organizados entre ausência de pontuação em estruturas que delas prescindiam, ou a presença de pontuação em estruturas que não a requerem. A ocorrência de cada problema foi analisada a partir dos dados das produções de textos e confrontada com trecho do texto falado que compartilhava mesma natureza.

Para compreender melhor as análises acústicas, algumas informações são importantes. É preciso identificar na imagem de análise o que se está sendo enfocado, para que essas 
informações sejam significativas do que se pretende discutir. Dessa forma, a imagem a seguir apresenta os elementos de análise acústica.

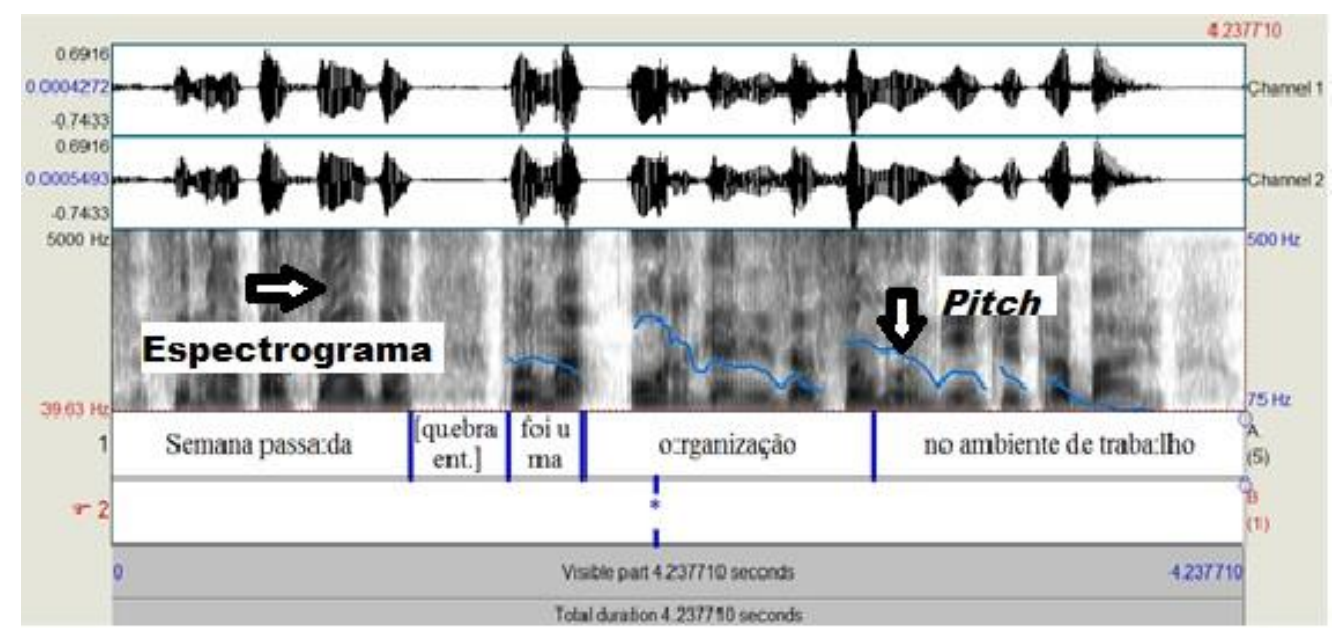

Figura 29 - O que se observar na análise acústica do programa PRAAT

Para a presente pesquisa, os elementos fundamentais a se identificar na imagem PRAAT são a curva entonacional, ou seja, o pitch, curva em azul, e o espectrograma. Caso algum elemento a mais seja acrescentado na análise, como os formantes, esse será indicado ao longo da análise. Sobre esses conceitos, vale citar, mais uma vez, o ensinamento de Mateus (2004: 6):

O tom (ou pitch) tem como correlato acústico a frequência da onda sonora, ou seja, o número de vezes que um ciclo completo de vibração das partículas se repete durante um segundo. Quanto maior o número de ciclos de vibração das partículas, maior e a altura do som e, portanto, mais "alto" é o tom. A frequência fundamental relaciona-se de um ponto de vista articulatório, com as cordas vocais: quanto mais delgadas, maior numero de vibrações, maior altura do som.

Uma sequência de segmentos com os respectivos tons cria a entoação dessa sequência, quer se trate de uma palavra ou de um grupo de palavras.

Apenas para retomar, então, o pitch é responsável pela marcação da curva entonacional e o espectrograma marca a frequência da onda sonora. Assim, com esses elementos, será possível analisar os fenômenos linguísticos que se deseja investigar: a quebra entonacional, representada por vírgula ou ponto final na escrita, e o fluxo contínuo da fala.

As informações aqui apresentadas mostram o percurso investigativo, cada decisão que fundamentou e moldou as análises, as discussões e as conclusões a que esse estudo conduz. Por vezes, o caminhar é tão ou mais interessante que o chegar, e para esta pesquisa, certamente, essa noção se aplica, já que acompanhar o desenvolvimento dos alunos e durante a coleta de 
dados, e a emersão, a partir das produções de texto, dos fenômenos linguísticos investigados foi tão enriquecedor quanto os resultados a que se chegou. E tudo isso será apresentado a seguir. 


\section{Capítulo 4 - Descrição e análise dos corpora}

Bem longe de dizer que o objeto precede o ponto de vista, diríamos que é o ponto de vista que cria o objeto. (Saussure).

Este capítulo é o coração do trabalho que vem sendo apresentado. Aqui serão discutidos os dados produzidos pelos 150 textos analisados, além dos obtidos nas respostas do questionário respondido por 41 dos alunos em foco. Além disso, há também a análise acústica de dados de fala, com os quais alguns resultados relativos aos textos escritos serão comparados. São, portanto, três corpora que demonstrarão como os estudantes do sexto ano da Escola Internacional compreendem alguns conceitos relativos ao ensino de produção de textos e como eles usam a língua em sua modalidade escrita para defender seus pontos de vista.

Nos corpora apresentados e analisados, poder-se-á observar como os alunos iniciam o processo de sistematização do uso da tipologia argumentativa, conforme o texto escrito exige. Essas produções irão confirmar ou refutar as hipóteses norteadoras dessa pesquisa, em que se propõe a (i) mapear os principais problemas de estrutura do texto argumentativo produzidos por alunos do sexto ano; (ii) analisar a compreensão dos alunos acerca da organização de textos argumentativos escritos, (iii) verificar em que medida a língua falada influencia na organização do texto escrito, quando se exige o uso da norma padrão da língua; e (iv) observar a influência da prosódia da língua falada sobre a organização textual escrita em casos específicos de uso da vírgula.

Nas próximas páginas serão apresentadas as análises feitas dos dados e, durante essa etapa, os corpora serão descritos e os resultados encontrados serão discutidos com base nas teorias apresentadas nos capítulos um e dois. A análise se inicia com as respostas do questionário aplicado, que constituem o corpus I desta pesquisa. Cada resposta foi investigada e as conclusões que elas proporcionaram foi justificada com exemplos transcritos dos textos dos alunos. Seguindo essa etapa, o corpus II será explorado e os resultados das análises serão apresentados de acordo com a ordem de macrocritérios delimitados na matriz de correção de produção de textos elaborada para esta pesquisa. Ao longo da discussão do último macrocritério delimitado, Pontuação, será feita uma comparação entre os dados do corpus II com o corpus III. Essa análise comparativa encerra o capítulo e abre espaço para a discussão didática que se propõe no capítulo cinco. 


\section{4.a O corpus I, o questionário}

Foi aplicado um questionário para 41 alunos, por meio do qual foi possível reforçar a ideia de que a organização textual escrita é abstrata para o aluno no início do Ensino Fundamental II. As respostas revelaram que há falta de compreensão de alguns sobre a funcionalidade da paragrafação no texto escrito. Isso reforça o caráter artificial da língua escrita, em uma realidade na qual a fala é o elemento principal de comunicação. Os alunos demonstraram não perceber na fala a mesma organização textual da escrita, o que dificulta a organização textual nessa modalidade.

Uma informação que se deve levar em conta, para a análise das respostas obtidas no questionário, é que o instrumento foi aplicado no início do segundo semestre letivo, ou seja, nos momentos iniciais do terceiro bimestre. A essa altura, os alunos já tinham estudado, de forma sistematizada, a organização estrutural do texto argumentativo, e isso se deu nas disciplinas de língua portuguesa e de língua inglesa. Dessa forma, é possível afirmar que as perguntas versavam sobre pontos já comuns aos participantes da pesquisa, e, por isso, a expectativa em relação a respostas que demonstravam estranheza ou desconhecimento sobre a funcionalidade do parágrafo era baixa. Mais adiante, os dados indicarão que isso foi parcialmente contrariado.

A fim de verificar os hábitos dos alunos, as questões iniciais versavam sobre idade e preferências relacionadas à leitura, como pode ser visto na Imagem 01, a seguir. Em relação à idade, os 41 participantes da pesquisa tinham entre 10 e 12 anos. Assim, nota-se que eles são parte de uma geração que cresceu em meio aos avanços tecnológicos, para os quais a comunicação via aparelhos celulares e outros meios eletrônicos é natural. Isso chama a atenção para o lugar da escrita em suas vidas, já que, com frequência, produzem textos escritos para se comunicarem. Isso poderia trazer, para eles, maior familiaridade com as produções de textos escritos, porém não foi isso que os dados indicaram ao longo desta investigação.

Idade:

Gosta de ler?

Quantos livros por mês você lê?

Você tem o hábito de ler na internet? Se $\operatorname{sim}$, o quê? 
Segundo a $U B L$, a gramática emerge do uso. Com base nisso, é possível compreender que a leitura favorece o uso da língua escrita. Por meio desse hábito, é possível consolidar conhecimentos em relação à estrutura linguística, ampliar o vocabulário, além de se aprimorar a grafia das palavras, ponto sensível observado nos dados. A crença, já consolidada pelo senso comum, de que um bom escritor é, antes de tudo, um ótimo leitor motivou a pergunta sobre leitura no instrumento apresentado. Os alunos da Escola Internacional44 possuem alto poder aquisitivo, o que dá a eles acesso quase ilimitado a uma vasta possibilidade de leitura de alto nível. Assim, a expectativa era que essa característica influenciasse positivamente o hábito de leitura dos alunos, tornando-os leitores vorazes de bons textos e, seguindo essa linha de raciocínio, bons escritores. Vale ressaltar que, apesar da complementariedade que há entre leitura e escrita, é preciso ter sempre clara a noção de que são competências diferentes que exigem habilidades específicas e próprias a cada uma delas.

Nesse aspecto, os dados indicam que o gosto pela leitura está presente entre os alunos, já que apenas $15 \%$ deles revelaram não gostar de ler. Por outro lado, reunindo os que indicaram gostar de ler (49\%) com os que gostam "mais ou menos" (36\%), percebe-se que os participantes da pesquisa estão inseridos em um contexto favorável ao uso da língua escrita considerado como padrão pelas escolas brasileiras e documentos oficiais.

Outro ponto a se observar é o quantitativo de livros lidos indicado pelos alunos. Foi indicado entre zero e dez livros lidos por mês. Sobre isso, vale a pena considerar que, para a disciplina de língua portuguesa, é exigida a leitura de um livro por mês. Assim, aqueles que indicaram que não leem, sequer, um livro por mês, revelam que não cumprem o mínimo exigido pela escola. Em contrapartida, a qualidade da leitura daqueles que afirmam ler dez livros mensais é questionável, já que todos têm uma grande quantidade de atividades e tarefas escolares a serem cumpridas.

\footnotetext{
${ }^{44}$ Nome criado para fazer referência à escola em que os dados foram coletados. Sobre essa questão, verificar o capítulo 02 .
} 


\section{Gosta de ler?}

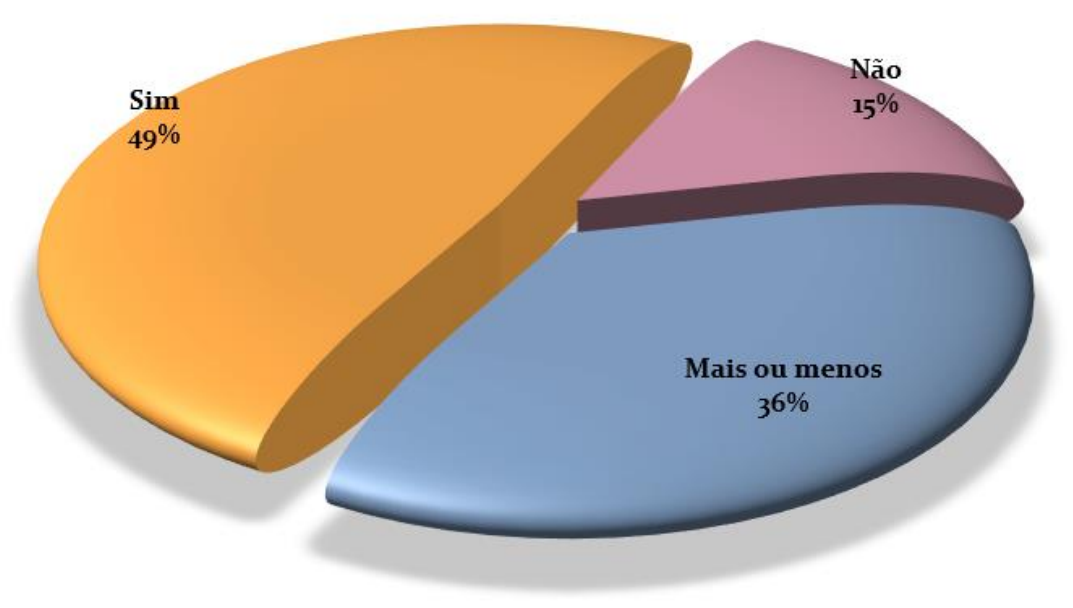

Gráfico 2-Você gosta de ler?

Os dados indicam ainda que, na contramão do avanço tecnológico, vinte e três, dos quarenta e um, alunos entrevistados preferem a leitura em livros físicos, não na internet. A leitura com intermédio da tecnologia se concentra em notícias, mensagens, blogues, pesquisas, fóruns e informações relacionadas a esportes. Apenas dois alunos revelaram preferir ler obras literárias em meio eletrônico.

A segunda etapa do questionário teve como objetivo verificar os conhecimentos dos estudantes do sexto ano acerca da organização textual e da relação entre texto escrito e texto falado. As duas primeiras perguntas são objetivas e aferem o gosto dos alunos em relação à produção de texto. Sobre isso foi possível concluir que é pequena a diferença entre os que gostam e os que não gostam de produzir textos escritos. Seguem as informações relativas ao questionário e às respostas dos alunos.

1. Você gosta de produzir textos?
( ) $\operatorname{Sim}$
( ) Não
( ) Mais ou menos

2. Que tipo de textos você mais gosta de produzir? Marque apenas uma alternativa.

( ) Narrativos - que contam histórias.

( ) Argumentativos - que apresentam opiniões.

( ) Diários - que contam suas experiências e sentimentos.

( ) Nenhuma das respostas anteriores (N.R.A.).

Figura $31-$ Questionário parte 2 
É interessante retomar a relação dos alunos com a leitura mediada pela tecnologia. Conforme apresentado acima, há uma preferência pela leitura tradicional, em papel. Isso, relacionado ao resultado abaixo apresentado, demonstra que ações como conversas realizadas por mensagens de textos, interação em redes sociais e em jogos em rede não são consideradas, pelos alunos, leitura, tampouco produção de texto, mesmo que as principais habilidades envolvidas nesses processos sejam as mencionadas. Assim, os $44 \%$ de alunos que declaram gostar de escrever não estão considerando como texto escrito os que promovem a comunicação, como os correios eletrônicos e chats.

Os gráficos um e dois demonstram que o quantitativo de pessoas afeitas à leitura corresponde ao de pessoas que gostam de produzir textos escritos. Isso reforça a ideia, mencionada anteriormente, de que o hábito de ler influencia o hábito de escrever. E ambos fortalecem o uso da língua dentro da variedade tida como padrão pela escola.

Estudos, como o de Kleiman (2007), indicam que a prática da escrita precisa ser compreendida pelo aluno como forma de interação social, ou seja, como prática discursiva. Assim, é importante que a escola intervenha nesse processo, fazendo com que o aluno perceba a necessidade de produzir textos com alto nível de qualidade para que o processo comunicativo se realize com sucesso. Nessa perspectiva, é função da escola intervir no uso da língua escrita do aluno, tanto fazendo com que essa prática tenha significado e funcionalidade, quanto moldando padrões gramaticais altos da língua usada na produção dos textos. Com isso o aluno pode ressignificar o papel da produção de textos escritos em sua trajetória enquanto ser social, e trazer novos resultados ao gráfico dois, apresentado a seguir.

Você gosta de produzir textos?

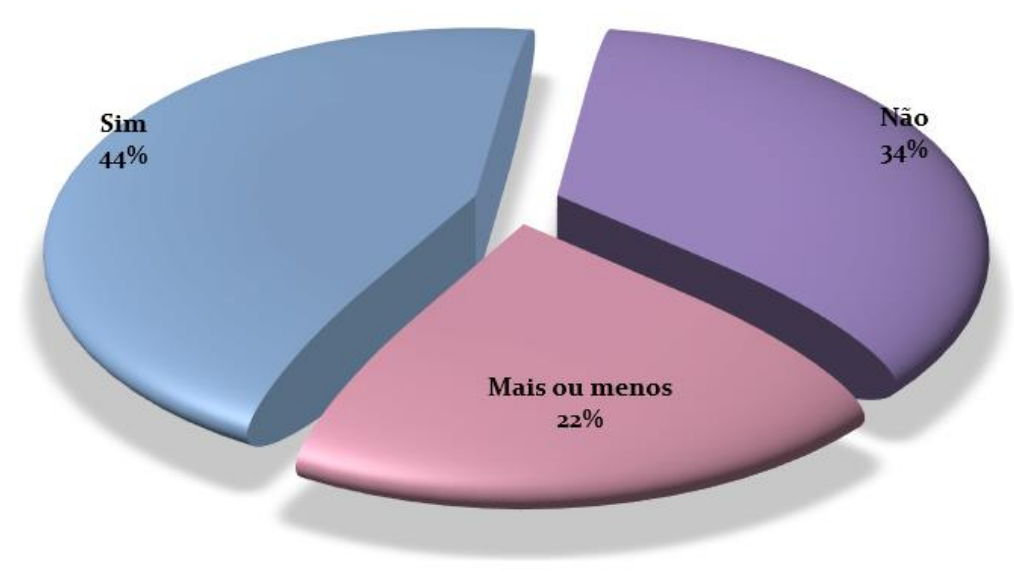

Gráfico 3-Questionário - Você gosta de produzir textos? 
O gráfico acima indica que $66 \%$ dos alunos se posicionam negativamente em relação à produção de textos escritos. Esse resultado indica que, apesar dos avanços nas pesquisas relacionadas ao trabalho com o texto em sala de aula, a prática redacional ocupa um lugar desprivilegiado no imaginário dos alunos do sexto ano, uma fase ainda inicial da vida escolar. Assim, fica ligado o sinal de alerta, pois, caso esse quadro não seja alterado durante o percurso escolar, o mais provável é que, cada vez mais, escrever textos seja um problema, que gere consequências negativas quando esse aluno chegar ao ensino superior e em sua vida profissional.

É útil para as análises seguintes considerar que, no questionário, havia a especificação para que o aluno usasse, em suas respostas, a norma padrão da língua portuguesa. Essa informação foi delimitada nas instruções do instrumento e reforçada pela pesquisadora ao longo da aplicação, e os resultados serão notados ao longo dos exemplos que ilustrarão as análises a seguir. As respostas deixam latente que, desde o início da vida escolar, é preciso enfatizar a distinção entre língua escrita e língua falada, assim como a existência da norma padrão do idioma e sua função social, pois os dados indicam que a transferência da fala para a escrita é um problema que deverá ser trabalhado com os alunos em foco, mas que já deveria ter sido sanado durante a fase de alfabetização.

A terceira pergunta do questionário direciona o foco do aluno para a estruturação do texto e inicia o rol de perguntas focais, além de ser a primeira discursiva do instrumento. Conforme já mencionado no capítulo metodológico deste estudo, as perguntas discursivas são respondidas textualmente, por escrito, e, como o texto escrito é o objeto desta investigação, o aluno, ao apresentar suas ideias sobre os questionamentos, produz, simultaneamente, dados que podem confirmar os resultados das análises feitas com base no corpus II.

A pergunta três é uma tentativa de compreender a percepção dos estudantes em relação ao parágrafo. Em razão disso, seu enunciado indagava: “para você, o que é o parágrafo?”. As respostas foram fidedignamente copiadas e separadas em quatro categorias: (i) relaciona o parágrafo com a organização textual; (ii) relaciona parágrafo com o leitor do texto; (iii) relaciona parágrafo e manutenção temática (ideia); e (iv) não demonstra conhecimento consistente sobre parágrafos, em ordem de relevância de critérios para a pesquisa. Cada resposta foi computada apenas uma vez, de forma que, se o aluno, em sua resposta, relacionou organização com a manutenção de ideias, esse dado foi considerado apenas na categoria relacionada à organização. Os resultados confirmaram a percepção da pesquisadora, para quem 
o aluno percebe a paragrafação como um conceito abstrato e não uniforme. A quantificação dos dados é apresentada no gráfico a seguir.

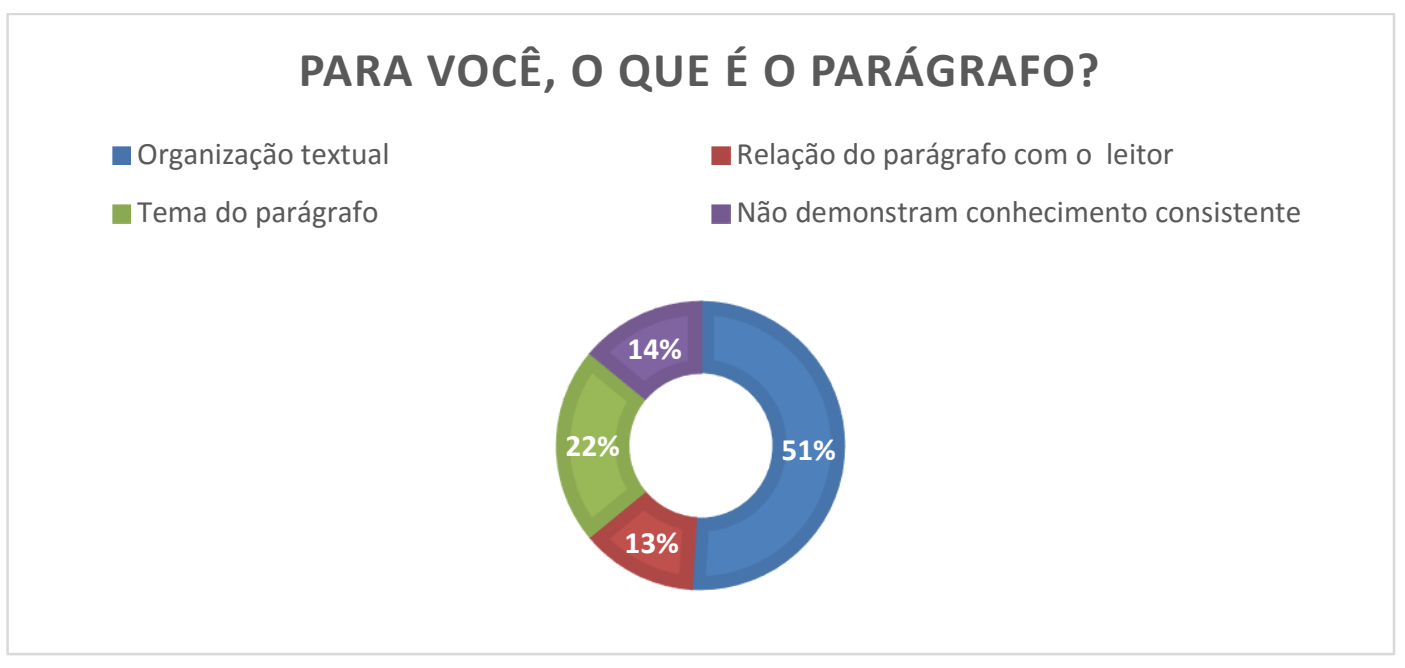

Gráfico 4 - Questionário, pergunta 3.

O gráfico revela que, dos 41 alunos respondentes, 14\% deles não demonstram conhecimento consistente sobre o parágrafo, ou seja, seis alunos usam a estrutura, reconhecem que ela existe, mas não compreendem seu objetivo em um texto. Assim, tem-se respostas como as seguintes para a pergunta em foco.

\begin{tabular}{|l|l|}
\hline Aluno 07 & Um espaço que colocamos quando vamos fazer uma produção de texto. \\
\hline Aluno 10 & Uma coisa que nois usa nós nossos textos que são bem chatinhos. \\
\hline Aluno 15 & $\begin{array}{l}\text { Para mim os paragrafos são outras partes de historia ou outros assuntos } \\
\text { depende do texto. }\end{array}$ \\
\hline
\end{tabular}

Esses alunos demonstram compreender que o parágrafo é um elemento textual, mas não conseguem perceber sua função, mesmo usando-os em sua prática acadêmica e tendo estudado sobre isso em suas aulas de línguas portuguesa e inglesa. É possível notar a confusão conceitual nas respostas, que deixam visíveis algumas lacunas na formação do aluno, como a própria noção de texto. A noção perceptível no exemplo do Aluno 15, ao relatar que "paragrafos são outras partes de historia ou outros assuntos depende do texto" (sic), deixa margem a se compreender que, para o aluno, alguns textos apresentam parágrafos, ao passo que outros, não. Outra possibilidade de análise dessa resposta é que o aluno compreenda que tranquilamente a noção 
de parágrafo, considerando que há, inclusive, paragrafação em diversas tipologias textuais. Caso o caminho interpretativo demonstre que a hipótese 1 é a mais plausível, deve-se considerar que, exceto em gêneros textuais que apresentam formas próprias de organização, como a história em quadrinhos, os textos com os quais o aluno mais tem contato em contexto escolar são organizados em parágrafos, e o estudante apenas relacioná-lo com histórias - narrativas põe em cheque o processo de ensino da língua portuguesa até então. É básico que o aluno, no sexto ano, perceba que os textos vão além das narrativas e são organizados em parágrafos.

Cinco alunos, $13 \%$ dos respondentes, demonstram maturidade ímpar ao se alinharem às teorias de Bakthin (2002) e definirem o parágrafo como estrutura textual que colabora com o trabalho do leitor. Essa noção pode ser verificada nos próximos exemplos.

\begin{tabular}{|l|l|}
\hline Aluno 03 & Para avisar ao leitor que, ira falar sobre um outro assunto. \\
\hline Aluno 28 & $\begin{array}{l}\text { Para mim, é um jeito de organizar as minhas ideias, quando escrevo e } \\
\text { ajudar o leitor a compreender melhor o texto. }\end{array}$ \\
\hline Aluno 31 & $\begin{array}{l}\text { O parágrafo é para mim a separação do texto em partes para que fique } \\
\text { mais fácil entender o texto melhor e fazê-lo ficar mais interessante para o } \\
\text { leitor. }\end{array}$ \\
\hline
\end{tabular}

Seja em relação ao assunto, ou em relação à organização textual, esses $13 \%$ dos alunos conseguiram perceber um fundamental elemento na produção de qualquer texto, escrito ou falado: o interlocutor/leitor. Essa delimitação influencia diretamente outras escolhas comunicativas, como a extensão do texto, a seleção vocabular, o grau de formalidade, a linguagem, o gênero textual e sua estruturação. Não se pode perder de vista a comunicação, e, para que essa se processe eficazmente, é preciso que o autor e seu interlocutor estejam em sintonia, e o parágrafo colabora para que isso aconteça.

É interessante também perceber o conhecimento que os alunos demonstram deter acerca da relação entre organização do assunto e conteúdo informacional, ao mencionarem que o parágrafo indica a troca de assunto. Esse é um conceito bastante presente em materiais didáticos, sobretudo naqueles utilizados no segmento em foco. A relação mencionada faz o gancho com o próximo critério de análise, a relação de parágrafo com as ideias do texto.

\begin{tabular}{|l|l|}
\hline Aluno 24 & É a parte de um texto onde se passa um só assunto. \\
\hline Aluno 33 & Paragrafo são grupos de frases que produzem a mesma ideia. \\
\hline
\end{tabular}




\begin{tabular}{|l|l|}
\hline Aluno 35 & $\begin{array}{l}\text { Para mim parágrafo é um espaço entre a margem e a frase que determina } \\
\text { quando o assunto é mudado. }\end{array}$
\end{tabular}

Percebe-se que, para alguns alunos, o parágrafo reúne informações acerca de uma única ideia ou um único assunto. Nota-se também que a mudança de assunto demarca a mudança de parágrafo. Tal visão alinha-se com a teoria de Bakhtin (2002) de que não é possível, em um parágrafo, desenvolver uma ideia por completo. Essa noção, apontada por 22\% (9 alunos) dos respondentes já indica que eles têm a noção de que, em um texto, há mais de uma ideia sendo desenvolvida, e, dessa forma, haverá mais de um parágrafo.

A resposta do Aluno 35 trata, ainda, do caráter visual que o parágrafo tem, o que é importante para guiar o leitor. Com mais esse elemento, pode-se concluir que os alunos do sexto ano têm noção do que seja um parágrafo, mas que esse não é um conhecimento consistente para grupo, mesmo que $86 \%$ dele saibam definir parágrafo e explicar sobre seu uso e função em um texto.

Nos dados, $51 \%$ das respostas relacionam parágrafo à organização. Nelas, é comum o uso de termos como "grupo", "estrutura" e "partes", o que demonstra a noção, já conhecida pela maioria, de que um parágrafo estrutura um texto escrito, e, segundo resposta que será analisada aqui, somente do texto na modalidade escrita. Os próximos exemplos apresentam três respostas de alunos que percebem o parágrafo como organização textual.

\begin{tabular}{|l|l|}
\hline Aluno 01 & Parágrafo é a organização nos textos. \\
\hline Aluno 14 & Parágrafo é uma estrutura de organização de textos. \\
\hline Aluno 19 & $\begin{array}{l}\text { Parágrafo pra mim é um modo de organizar o início, meio e fim de uma } \\
\text { história, narrativa, texto, etc. }\end{array}$ \\
\hline
\end{tabular}

A resposta do aluno 19 demonstra haver problemas com a noção de o que é texto, apesar de o material didático usado durante o sexto ano ter a teoria dos gêneros textuais como parte de seu arcabouço teórico e trabalhá-la com os alunos logo nos primeiros capítulos. O material apresenta a definição de que toda comunicação se processa em textos, independentemente da modalidade ou do tipo textual, e trabalha com esse pressuposto ao longo das atividades de 
análise linguística e interpretação de texto. Porém, esse também é um conceito abstrato, que implica a desconstrução, para o aluno, do que ele percebe como texto.

Nessa fase, os alunos entendem que texto é aquele em que há parágrafos escritos, como livros e materiais escritos relacionados ao ambiente escolar. Eles têm grande dificuldade de compreender que uma tirinha, por exemplo, é um texto, assim como alguma produção falada, como um debate oral ou a própria aula. Além disso, alguns alunos diferenciam história de texto, e isso demonstra que, para eles, a tipologia também influencia em sua percepção da estrutura em foco. Isso pode ser confirmado na resposta do aluno 15 para a quarta pergunta do questionário (“Em sua opinião, para que serve o parágrafo?”), na qual afirma que "Para mim, (o parágrafo) serve para você organizar sua história ou texto". Outra resposta também chama a atenção por relacionar a definição de parágrafos com a tipologia. Segundo o aluno 22, o parágrafo serve "Para comesar e enserar uma opinião. (sic)", relacionando a existência de parágrafo com o tipo argumentativo, assim como o aluno 15 faz com a narrativa.

As respostas dos participantes da pesquisa à pergunta quatro confirmam os resultados das respostas à pergunta três, já que 63,5\% demonstram perceber que a função textual do parágrafo é organizar o texto, e utilizaram exatamente o termo 'organizar' em suas respostas. Outros $14,6 \%$ conservaram a ideia de organização textual, mas utilizaram vocábulos como 'separar' e 'dividir'. Os alunos 19 e 31 percebem a função do parágrafo como sendo a de organizar o texto em início, meio e fim, percepção também ligada à organização. Dessa forma, percebe-se que $78,1 \%$ das respostas relacionam o parágrafo com organização. Além disso, 7,3\% relacionam parágrafo e assunto, e 14,6\% se mostraram confusos com relação à pergunta, e afirmaram que o parágrafo serve, por exemplo, para "quebrar sua cabeça nos textos" (aluno 38), ou para "exatamente nada" (aluno 9). O gráfico subsequente representa esse resultado.

\section{Em sua opinião, para que serve o parágrafo?}

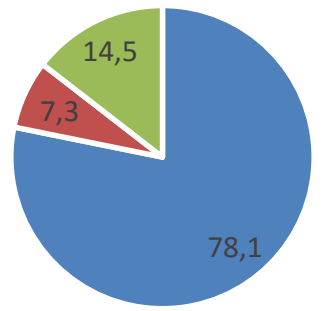

- Respostas relacionadas à organização textual - Respostas relacionadas ao assunto = Outros 
A questão cinco objetiva verificar como os alunos compreendem a organização do parágrafo. Da pergunta três para a cinco, a linha de raciocínio seguida é partir do maior, que é o conceito, para o menor, que é a estruturação do parágrafo. Assim, pode-se verificar a compreensão sobre definição de conceito, função e composição do objeto em análise, o parágrafo. Até aqui, nota-se que os alunos do sexto ano têm mais facilidade para compreender para que serve o parágrafo do que para conceituar tal estrutura, e também para determinar sua composição.

As respostas em foco apontaram grande confusão e pouca compreensão de como se estrutura um parágrafo. As respostas mais consistentes estão relacionadas a frases e desenvolvimento de assunto, como se pode verificar nos próximos exemplos. Porém elas apenas reproduzem as lições trabalhadas nas aulas de língua portuguesa e de língua inglesa, e não demonstram que os alunos tenham se apropriado de fato desse conhecimento.

\begin{tabular}{|l|l|}
\hline Aluno 01 & Tem uma frase principal, três complementares e uma frase final. \\
\hline Aluno 05 & $\begin{array}{l}\text { O parágrafo é organizado em frase inicial, duas a três frases de } \\
\text { desenvolvimento e uma frase de conclusão. }\end{array}$ \\
\hline Aluno 31 & $\begin{array}{l}\text { O parágrafo é organizado em três partes, início do texto, meio ou } \\
\text { problema, e fim ou solução. }\end{array}$ \\
\hline
\end{tabular}

Além dessas, chamam atenção respostas que evidenciam a dificuldade dos alunos em relação à estrutura em foco. Alguns deles relacionam a composição do parágrafo com a organização espacial, assim, o Aluno 14 afirma que "parágrafo se inicia com um espaço da margem ele é organizado em algumas linhas" (sic) e o Aluno 35, que o parágrafo se organiza "Com um espaço entre a margem e a frase". Outros relacionam com a progressão temática ou organização, porém com alguns equívocos conceituais, como os exemplos a seguir.

\begin{tabular}{|l|l|}
\hline Aluno 06 & É organizado em tópicos diferentes. \\
\hline Aluno 07 & $\begin{array}{l}\text { Você tem que colocar dois dedos na frente do texto e toda vez que o texto } \\
\text { for mudar de assunto você tem que colocar um parágrafo. }\end{array}$ \\
\hline Aluno 40 & Com parágrafos. \\
\hline
\end{tabular}


Como finalização da investigação sobre o conceito de parágrafo no questionário, a pergunta seis tenta propor um desafio a mais para o aluno, que precisaria justificar a resposta dada a uma questão de múltipla escolha sobre a relação entre parágrafo, fala e escrita, como é possível conferir a seguir. Nesse ponto, buscou-se lançar luz à relação fala e escrita, no olhar do aluno, tendo em vista que, até então, enfocava-se o conceito em si, não especificamente uma ou outra variação linguística.

6. Das opções abaixo, marque apenas uma alternativa. Em seguida, explique a razão de sua escolha.

a) ( ) O parágrafo só existe nos textos falados (em conversas, aulas, palestras, diálogos de filmes etc.).

b) ( ) O parágrafo existe nos textos escritos e nos textos falados.

c) ( ) O parágrafo só existe nos textos escritos.

d) ( ) O parágrafo não existe.

Justificativa.

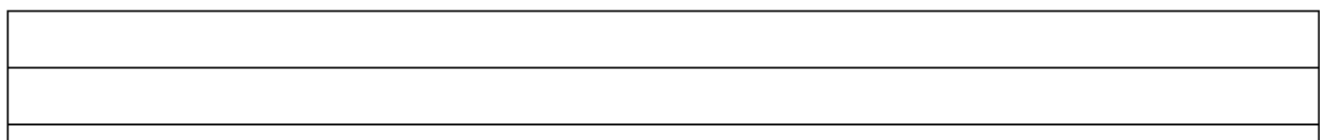

Figura 32 - Questão 06

Ao se enfocar a dicotomia básica da língua portuguesa, os dados indicam que fala e escrita não são vistos como partes de um continuum, para os alunos, e sim como elementos diferentes, já que 33 respostas para essa pergunta afirmaram que o parágrafo só existe no texto escrito. Assim, não compartilham da organização por meio dessa estrutura. Esse resultado reforça a percepção da pesquisadora, pois esse foi considerado no momento da elaboração do questionário.

Os $82,5 \%$ dos alunos que entendem só haver parágrafos no texto escrito confirmam o que já foi aqui mencionado, sobre a dificuldade de os alunos entenderem que o texto é a língua em uso, é a comunicação se processando, e que podem ser compostos por diferentes linguagens e variedades da linguagem verbal. Mais uma vez ficam nítidos os resultados da abordagem que a escola dá em relação a textos, relacionando-os com a escrita, sem privilegiar o uso da língua que os alunos já dominam ao chegarem ao ambiente escolar, a fala. Os resultados da pergunta seis estão no gráfico a seguir. 


\section{QUESTÃO 6}

\section{\ O parágrafo só existe nos textos escritos. \\ - O parágrafo existe nos textos escritos e nos textos falados. \\ ■ 0 parágrafo só existe nos textos falados.}

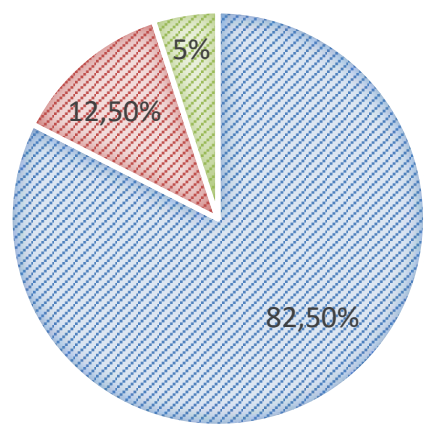

Gráfico 6-Questão 6

As justificativas apresentadas demonstram, mais uma vez, a complexidade de verbalizar o que é apenas uma percepção. Mais uma vez fica evidente que o trabalho feito na escola, em produção de texto, é construído em terreno arenoso, já que os alunos não têm consolidados conhecimentos básicos, sobre os quais importantes conceitos e práticas serão construídos, como os conceitos de texto e parágrafo. Atacar a inconsistência epistemológica dos alunos logo nos primeiros anos do Ensino Fundamental II pode garantir a aquisição de conhecimento significativo, e isso acarretará alunos que, ao final da educação básica, sejam proficientes em sua língua materna, produzindo textos escritos e falados com qualidade.

Retornando à apresentação das justificativas, nota-se que, apesar de não reconhecerem o parágrafo como parte de um texto falado, os estudantes em foco percebem que esse, assim como o escrito, apresenta uma organização, ainda que essa percepção seja confusa. $O$ aluno 08 afirma que "nos textos escritos você precisa de organização e nos textos falados não. Depende quando é uma conversa formal precisa sim de organização, mas em uma conversa informal (entre amigos) então não precisa de organização". Essa justificativa é contraditória, porém indicia a percepção de que um texto falado, ainda que em registro formal, necessita de organização.

Apesar de 5\% dos alunos marcarem que percebem a existência do parágrafo apenas em textos falados, não há justificativas que expliquem essa percepção. Pelo contrário, o mais 
recorrente é explicar que não se pode falar em parágrafo, como os exemplos apresentados a seguir. Dessa forma, os dados indicam que o aluno não transpõe a estrutura do texto escrito para o falado, por não relacionar um ao outro, no que diz respeito à organização textual, assim, é preciso considerar que a paragrafação não é um conhecimento subjacente à língua, simplesmente por não ser percebido na oralidade. Com isso, ela deve ser ensinada ao aluno, que deve, sistematicamente, aprender a usá-la.

\begin{tabular}{|l|l|}
\hline Aluno 05 & $\begin{array}{l}\text { Os parágrafos só existem nos textos escritos porque não falamos com } \\
\text { parágrafos. }\end{array}$ \\
\hline Aluno 22 & No texto falado a pessoa não marca o parágrafo. \\
\hline Aluno 26 & $\begin{array}{l}\text { O parágrafo só existe nos textos escritos porque se for falado ou outra } \\
\text { coisa não tem jeito de se identificar quando começa ou quando termina. }\end{array}$ \\
\hline
\end{tabular}

Apesar de a maioria, como já foi apresentado, indicar que o parágrafo só existe no texto escrito, $12,5 \%$ percebem que o texto falado também prescinde de organização, que é feita por meio dos parágrafos. Assim, assumem que o parágrafo é comum ao texto escrito e ao texto falado, além de apresentar justificativas como as seguintes.

\begin{tabular}{|l|l|}
\hline Aluno 15 & Parágrafo é uma coisa que tem em todos os textos. \\
\hline Aluno 28 & $\begin{array}{l}\text { Os parágrafos existem nos textos escritos e nos textos falados, pois é uma } \\
\text { forma de organização. Então, quando a pessoa começa ou conclui um } \\
\text { tema, por exemplo, ou algo de que está falando ou escrevendo, uma ideia, } \\
\text { é o começo de um novo parágrafo. }\end{array}$ \\
\hline Aluno 31 & $\begin{array}{l}\text { Os parágrafos existem nos textos escritos e falados porque é o que separa } \\
\text { o texto em partes, porque mesmo em textos falados têm ordem. }\end{array}$ \\
\hline
\end{tabular}

A questão seis do questionário encerra a etapa relativa à paragrafação. Outra estrutura importante do texto escrito é a pontuação, sobre a qual as próximas questões do questionário voltar-se-ão. A abordagem segue o mesmo direcionamento que a investigação sobre o parágrafo, partindo de pergunta relacionada ao conceito, depois à função, à situação de uso e, por fim, aborda-se a relação entre fala e escrita. Como pergunta de transição, foi feita a questão 
sete (ver Anexo 1), que tinha o objetivo de distrair os informantes durante o preenchimento do questionário, por isso seus resultados não serão analisados aqui.

Os resultados sobre a paragrafação indicavam grande confusão teórica por parte dos participantes desta pesquisa, e as respostas relativas à pontuação confirmam e ampliam essa noção. É possível identificar quatro eixos de sentido em relação ao conceito de pontuação, entre as respostas consideradas minimamente significativas, assim respostas como "não sei" (aluno 40) e "Eles são muito importantes. Eles mostram... eu sei o que é... mas eu não sei como explicar" (aluno 21) não foram consideradas.

Como primeiro eixo, pode-se observar a pontuação sendo percebida como agente na organização do texto, já o segundo eixo explora a ideia de a pontuação expressar emoção e atribuir sentido ao texto. $\mathrm{O}$ terceiro eixo relaciona escrita com leitura, e a pontuação seria a responsável por guiar o leitor; por fim, é o que relaciona texto escrito com a fala, indicando ser a pontuação responsável por pausas e marcas de finalização. Os exemplos seguintes confirmam essas observações.

\begin{tabular}{|l|l|l|}
\hline Aluno 02 & Eixo 01 & Alguns sinais para deixar seu texto mais organizado. \\
\hline Aluno 31 & Eixo 02 & $\begin{array}{l}\text { Os sinais de pontuação dão um tempo e voz ao texto, dando } \\
\text { sentido, como se a frase fosse uma exclamação, interrogação } \\
\text { ou ponto final para acabar a frase. }\end{array}$ \\
\hline Aluno 25 & Eixo 03 & Servem para ajudar na leitura, \\
\hline Aluno 14 & Eixo 04 & Eles são sinais gráficos que servem para pausar um texto. \\
\hline
\end{tabular}

A confusão conceitual anteriormente mencionada não diz respeito ao erro, pois, como se pode observar, as respostas dos alunos são pertinentes ao conceito de pontuação, inclusive aos trabalhados no capítulo anterior. A confusão está presente na fragmentação do conhecimento, pois nenhum dos alunos uniu os quatro eixos em sua resposta, o que pode indicar, ainda, uma fase de aquisição do conhecimento relativo a esse conteúdo. Além disso, pode-se relacionar a questão da organização textual ligada à pontuação com seus papeis sintáticos, e isso será trabalhado em anos posteriores.

As respostas até aqui têm sido significativas na materialização do ensino fragmentado que, apesar dos avanços científicos e pedagógicos, ainda vige nas escolas do país. Quando se pensou na pergunta em análise, não foi esperada uma resposta uniforme acerca da pontuação, mas a diversidade de respostas obtida trouxe ênfase à conceituação de pontuação, uma vez que, em alguma medida, os alunos utilizam pontos e vírgulas em seus textos. Esses resultados estão 
alinhados à percepção da pesquisadora de que é justamente a pontuação um dos pontos mais frágeis da escrita em língua portuguesa, em diversos níveis de ensino. Por isso os resultados aqui apresentados são importantes para se pensar no ensino de produção textual, já que é preciso atacar o problema de frente desde as séries iniciais do Ensino Fundamental I.

As respostas que os alunos produziram para a questão oito, relativa à conceituação de pontuação, é representativa das demais perguntas sobre o tema. Os quatro eixos propostos, anteriormente, são uma constante nas três perguntas seguintes, de forma que não vale a pena se ater a elas individualmente, contrariamente à abordagem feita nas questões sobre parágrafo. As questões nove e dez inquiriam sobre a função e o uso da pontuação sob o ponto de vista dos alunos, e confirmam que a maioria deles não tem a menor ideia de qual é a motivação que leva ao uso da pontuação.

Para fechar a análise das perguntas do questionário, uma última questão merece ser comentada. A questão onze era do tipo mista, na qual se pretendia verificar se os alunos percebiam o uso da pontuação em textos produzidos na modalidade escrita e oral.

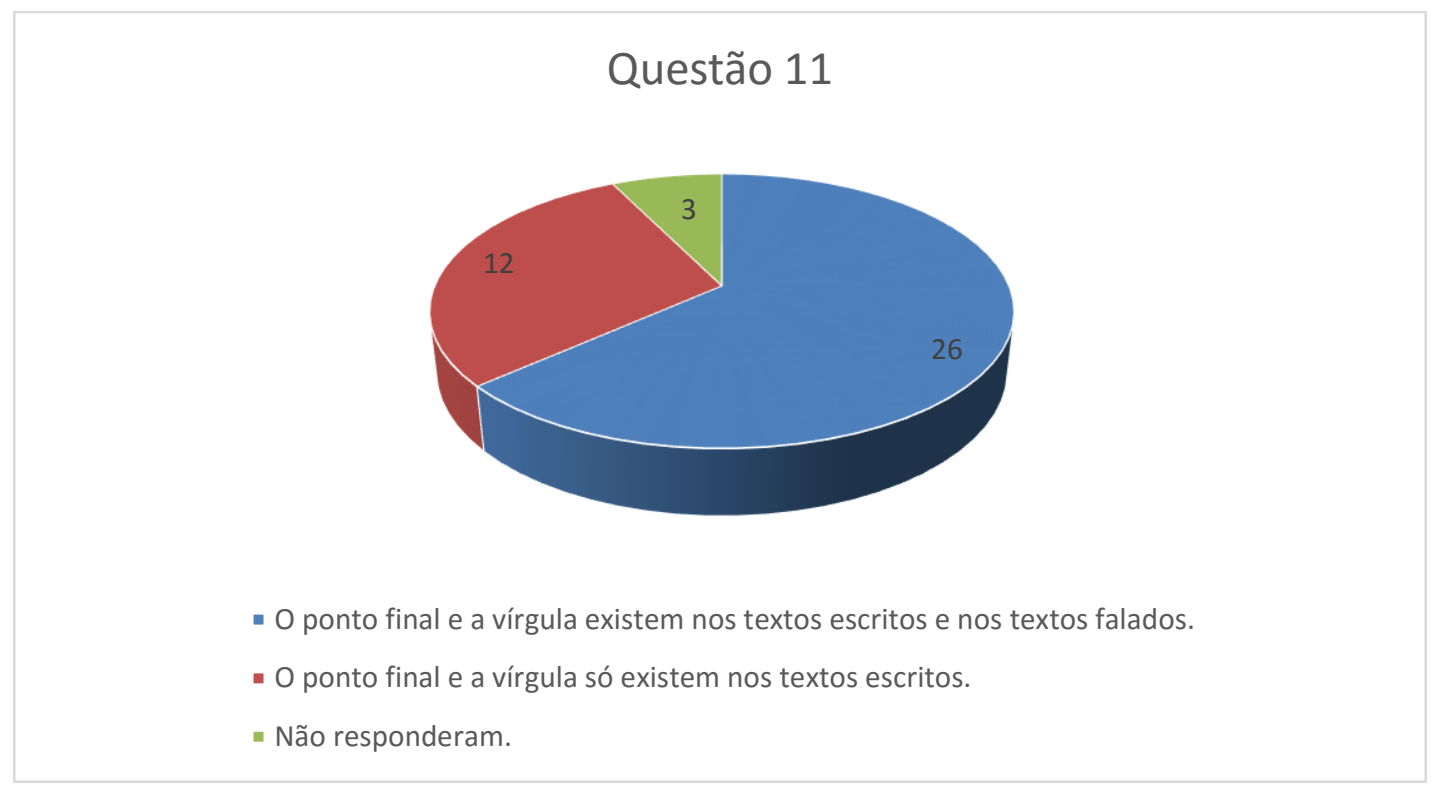

Gráfico 7 - Questão 11

Os resultados apresentados no Gráfico 6 demonstram que os alunos percebem que os sinais de pontuação existem nos textos orais e nos textos escritos, o que diverge na percepção da noção de parágrafo, que é majoritariamente compreendido como elemento próprio do texto escrito. As justificativas em relação à questão onze demonstram que a pontuação é percebida no texto oral em virtude das pausas que são feitas na fala, como confirmam as justificativas a seguir. 


\begin{tabular}{|l|l|}
\hline Aluno 01 & $\begin{array}{l}\text { Existem nos textos escritos e falados porque precisa ter vírgulas e ponto } \\
\text { final para ter um tempo para respirar. }\end{array}$ \\
\hline Aluno 18 & $\begin{array}{l}\text { Existe no texto falado porque quando você fala alguma coisa como "Pão, } \\
\text { vinagre e sal" você dá uma pausa no final, e no final da frase você termina } \\
\text { a frase. }\end{array}$ \\
\hline Aluno 25 & Porque você não fala tudo junto, você faz pausas. \\
\hline
\end{tabular}

Em geral, os textos das justificativas dessa questão são confusos e apresentam problemas estruturais que não foram observados em outros momentos do questionário. Isso pode ser tanto pelo cansaço dos alunos em virtude da extensão do instrumento, e essa era a última questão, quanto pode demonstrar que justificar a relação da pontuação na fala e na escrita é, de fato, complexo para os alunos do sexto ano. Essa pergunta foi a que teve mais justificativas em branco (6), ou com a resposta "não sei justificar" (3).

Algumas respostas defendem que somente o texto escrito apresenta pontuação, e tiveram justificativas que indicam a complexidade, para o aluno, do tema que está sendo enfocado. A relação entre elementos concretos e elementos abstratos volta à discussão, em que se percebe a fala como abstrata e a escrita como concreta, já que na primeira não se podem ver os sinais de pontuação.

\begin{tabular}{|l|l|}
\hline Aluno 03 & Pois não precisa falar vírgula ou ponto final em um texto falado. \\
\hline Aluno 08 & $\begin{array}{l}\text { Porque no JN (Jornal Nacional) eles não ficam: HOJE UMA PESSOA } \\
\text { MORREU VÎRGULA ISSO OCORREU EM SP PONTO DE } \\
\text { EXCLAMAÇÃO. Então a virgula e o ponto final só aparecem no texto } \\
\text { escrito. }\end{array}$ \\
\hline Aluno 11 & Porque os pontos e as vírgulas são que só tem na escrita gráficas. \\
\hline
\end{tabular}

Em algum momento da vida escolar dos alunos analisados, os sinais de pontuação foram ensinados a eles, já que seus textos apresentam, ainda que de maneira equivocada, esses recursos linguísticos. O que parece não ter sido feito é relacionar esses sinais ao sistema da língua, como de fato são. Não é preciso ensinar ainda a estrutura do período para essa faixa etária, mas apenas relacionar pontuação com respiração durante a leitura não está surtindo efeito. Conscientemente, alguns alunos não relacionam pausa na fala com vírgula na escrita, e as análises das próximas subseções indicarão se o fazem inconscientemente, para que se possa identificar se há relação entre entonação e pontuação nos textos escritos. 


\section{4.b O corpus II, as redações dos alunos}

A principal fonte de dados para análise desta pesquisa é o banco formado por 150 redações dos alunos. Conforme já explicado no capítulo metodológico, as redações foram produzidas entre o primeiro e o terceiro bimestres letivos da Escola Internacional, e formam considerável fonte de dados.

A seguir, serão apresentados os resultados da análise de erros empreendida nas redações. Os erros, ou desvios da norma padrão, serão analisados e comparados, quando possível, com as respostas dos questionários. Além disso, serão levantadas hipóteses para a motivação dos erros. Hipóteses, apenas, em razão do quantitativo de dados, já que se trata de uma amostra de redações, e também por se estar trabalhando com questões cognitivas, que requerem um longo percurso de análise e experimentação para que hipóteses sejam convertidas em afirmações categóricas.

\section{4.b.1 Escrita Formal}

Este macrocritério abarca quatro pontos de análise microestruturais: ortografia, concordância verbal, concordância nominal e acentuação. Desses, os dados indicaram que são mais profícuos os problemas relativos à grafia das palavras, juntamente com o uso equivocado do acento gráfico ou a ausência deles. O gráfico 8 apresenta os resultados da análise, relativa à escrita formal. 


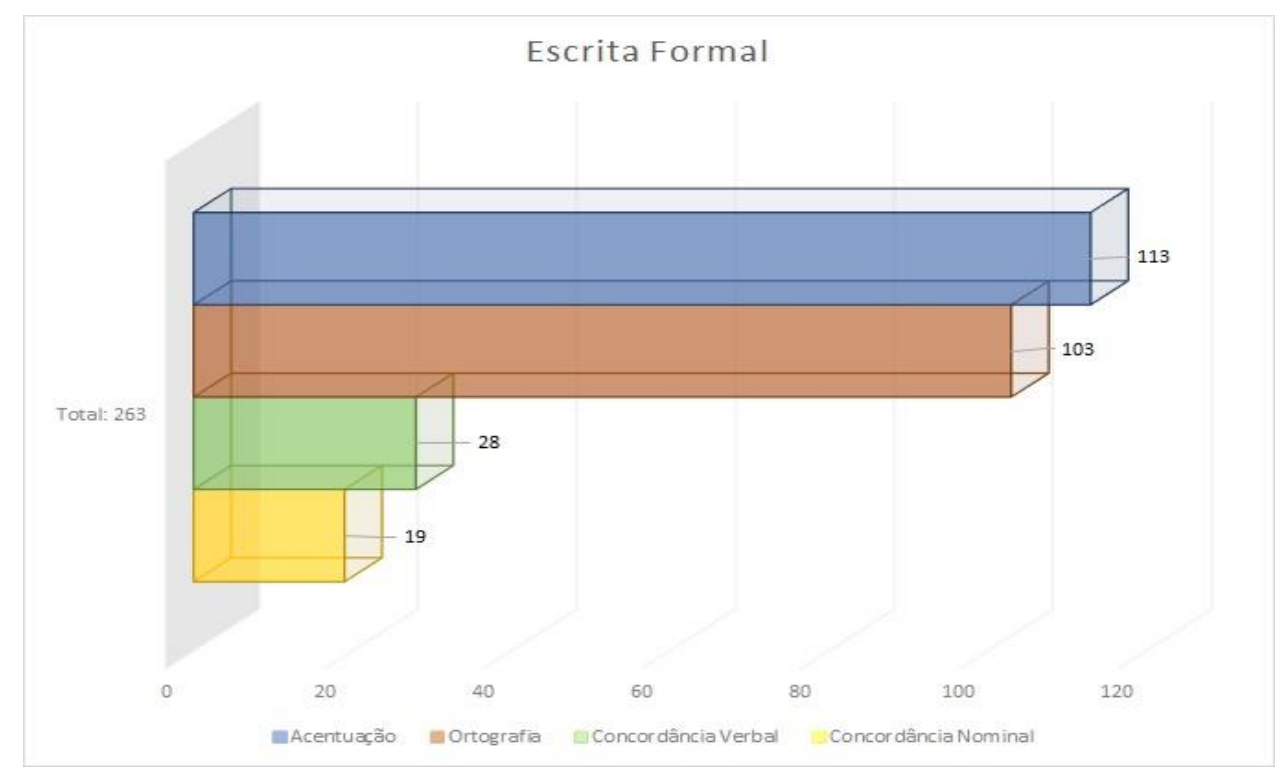

Gráfico 8- Escrita Formal

Como se pode observar, questões relativas à acentuação e à grafia das palavras são as mais recorrentes nos dados. Essa comparação não é somente em relação ao macrocritério Escrita Formal. Dentre todos os critérios analisados, esses dois problemas são os mais produtivos.

\section{Grafia das palavras e acentuação}

Os dados indicam que a correta grafia das palavras, para o público em foco, é um desafio que inspira maior investimento didático, com estratégias específicas para a solução do problema. Na tabela de critérios de avaliação das produções de texto, a ortografia está indicada sob a numeração $1 \mathrm{~d}$, que será usada também aqui. Por ser o critério da microestrutura mais frequente em relação à escrita formal, ele será o primeiro a ser abordado.

Observa-se que os erros acontecem, majoritariamente, no nível do segmento, por causa da falta de relação exata entre letra (escrita) e som (fala), própria da língua portuguesa. Assim, os dados apenas reforçam o que estudiosos como Lemle (2011), já constataram em seus estudos. Há também problemas de grafia relacionados ao segmento em que há a junção, na escrita, de 
duas palavras, o que reflete característica da fala, quando duas palavras formais formam uma palavra fonológica.

Nos exemplos selecionados, pode-se observar que a variação de letras para representarem um único fonema, no caso específico, o /s/ é problema para o aluno. Observa-se “converçar” por 'conversar', “comessar” por 'começar', “disleccia” por 'dislexia', “voçe” por 'você' e "serteza" por 'certeza'. Em todas essas palavras grafadas erradas, observa-se que a variação de letras existentes na língua portuguesa para se escrever o som de /s/ eleva a dificuldade de o aluno, no nível em foco, não cometer equívocos relacionados à ortografia.

Lemle, no "Guia teórico do alfabetizador", aponta que a relação entre letra e som, na língua portuguesa, é uma das primeiras dificuldades que o alfabetizando precisa superar. Segundo ela, poucos são os casos em que há relação direta entre letra e som, ou seja, de uma letra representar um e unicamente um som. Isso acontece, no dialeto carioca, apenas com as letras que representam, graficamente, os fonemas /p/, /b/, /t/, /d/, /f/, /v/ e /a/. Quando o aluno chega ao sexto ano, grande parte dessa primeira dificuldade já deveria ter sido superada, porém os dados indicam que essa dificuldade pode perdurar, permanecendo durante a fase escolar, e não seria exagero afirmar que podem chegar à fase adulta do indivíduo, se não for trabalhada sistematicamente ao longo do percurso escolar. Os exemplos apresentados no parágrafo anterior evidenciam os prejuízos que os alunos analisados já apresentam em relação à ortografia, os quais poderiam ter sido minimizados se a fase de alfabetização tivesse sido mais enfática nesses pontos críticos.

Os dados mostram, ainda, que a relação entre letra e som não é o único problema ligado à ortografia, em relação ao grupo estudado. Há também problemas que evidenciam a relação entre grafia e prosódia, por isso merecem ser analisados com atenção. A segmentação das palavras também é fator de dificuldades para os alunos, e vale ressaltar que, aqui, quando se trata de segmentação, não está em jogo as palavras localizadas em final de linha, ou seja, não se abordará questões relativas à translineação. Problemas de segmentação relacionados à translineação não foram abordados neste estudo.

Abaurre (1991) se debruça sobre a questão e a chama de segmentação não-convencional. Esse problema também foi apresentado na referida obra de Lemle (2011), na qual essa linguista menciona que outra dificuldade do alfabetizando é ter consolidado o conhecimento de palavra. Em razão da complexidade do problema em foco, estudiosos como Abaurre (1991), Tenani (2011) e Chacon (2013) estudam a ocorrência das segmentações não-convencionais do Ensino Fundamental. 
A definição das segmentações não-convencionais tem a ver com a ocorrência do espaço em branco entre uma palavra formal e outra, na escrita. Isso demonstra a percepção que o indivíduo tem da língua oral. Há, dentre essas segmentações, a hipossegmentação e a hiperssegmentação. Na primeira, o espaço em branco entre uma palavra formal e outra é suprimido, como em "tenque" (1dPT047), por 'tem que', já na segunda, é introduzido um espaço em branco em posição na qual ele não existe, ou seja, uma palavra formal é segmentada em duas, como em “di dático" (1dPT005), por 'didático'.

Dentre as 150 redações, foram 18 ocorrências de hipo e hiperssegmentação. Iniciandose a análise pelos dados menos recorrentes, foram observados três dados que tinham relação com o uso do hífen, uma para cada tipo. Observou-se a ocorrência de hipossegmentação em “usálas”, por 'usá-las', e "respeitalos”, por 'respeitá-los', além de hiperssegmentação em “injusta-mente”, por 'injustamente'. Ademais, observou-se também um caso de redução de sílaba na palavra, e não de segmentação. Por não haver um espaço especialmente reservado para o tratamento de redução, e por se ter observada apenas uma ocorrência desse tipo de problema, é que se optou por mencionar tal ocorrência neste parágrafo. Houve o uso de "des" no lugar de 'desde', com o apagamento da sílaba átona.

Em relação às segmentações não-convencionais motivadas pela ocorrência, ou não, do espaço em branco, a tabela seguinte apresenta o resultado. Nele é possível confirmar as conclusões de Tenani (2011), e verificar que a hipossegmentação, no sexto ano, é o tipo de segmentação não-convencional mais profícua. Nela, observa-se que há a tendência de se suprimir o espaço em branco entre a sílaba átona anterior à palavra formal escrita, fazendo com que artigos e preposições sejam acoplados às palavras que os acompanha. Assim, há mais uma evidência que pode confirmar a influência da fala sobre a escrita, pois o apagamento de sílabas átonas é comum na oralidade, tanto que, formam, em geral, uma única palavra fonológica.

\begin{tabular}{|l|l|}
\hline Hipossegmentação - $12(66,72 \%)$ & Hiperssegmentação - 4 (22,3\%) \\
\hline Agente, ajente, porexemplo, haver ( a ver), & Deis de, im portante, che garem, em \\
envez (em vez), encima, deser (de ser), & $\begin{array}{l}\text { quando (enquanto) e di dático. } \\
\text { pelo omenos, derrepente, arelação (a } \\
\text { relação), tenque (tem que) e conserteza). }\end{array}$ \\
\hline
\end{tabular}

Tabela 5 - Hipo e Hiperssegmentação nos dados - ocorrências do sexto ano

Os dados relativos às hiperssegmentação não indicaram regularidade que pudesse elucidar a motivação para se acrescentar espaço em branco em meio à escrita de uma palavra 
formal em todas as ocorrências. É possível observar que em "im portante" e "em quando", a preposição parece motivar a hiperssegmentação, porém essa regularidade não se mantém em “che garem". Assim, nota-se que é necessário investir mais na investigação da hiperssegmentação para se compreender o fenômeno e se buscar formas eficazes de intervenção em sala de aula.

1dPT004 - "Hoje vou converçar sobre a importância da leitura (...)" // "Eu acho que tenho um pouco de disleccia(...)"

$1 \mathrm{dPT} 011$ - "ainda podem decidir se podem comessar a ler(...)"

$1 \mathrm{dPT} 005$ - “(...) sobre fatos reais ou livros di datico, conserteza a pessoa (...)"

$1 \mathrm{dPT} 040$ - "A leitura E um fator muito im portante".

$1 \mathrm{dPT} 150$ - "se voçe não tiver um iphone(...)"

$1 \mathrm{dPT} 047$ - "Em quando você for criança você tenque ler muito(...)"

Vale frisar que nenhuma das produções de textos analisadas nesta pesquisa foi produzida por alunos com laudos de disgrafia, dislexia, problemas cognitivos, ou de aprendizagem, que comprometessem a escrita. Um fator que deve ser considerado, contudo, é o fato de a escola oferecer um ensino bilíngue (português e inglês), pois a semelhança entre algumas palavras, comuns às duas línguas, influenciam a escrita de alguns alunos, como nos exemplos a seguir.

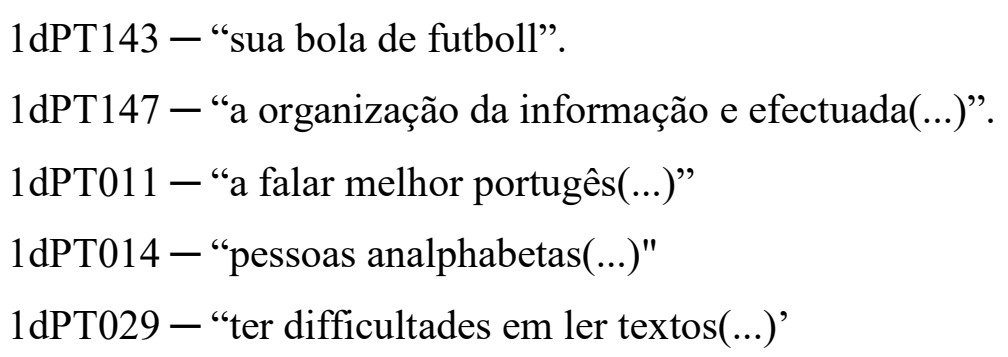

Outro microcritério de destaque em relação à Escrita Formal é a acentuação. Sobre isso, vale mencionar que não é somente o desconhecimento das regras de acentuação que vem influenciando na escrita dos alunos em geral. Cada vez mais, escrever é uma atividade frequente na rotina das pessoas, por conta da tecnologia que trouxe consigo uma série de ferramentas de comunicação em que a escrita é destaque, e isso sem contar as redes sociais, já comuns a tantas 
pessoas. Os alunos em foco também fazem uso dessas ferramentas de comunicação, e se observa uma forte influência da comunicação moderna com a qualidade da escrita dos jovens. Uma das principais consequências é o uso de acentos gráficos, que foram banidos da escrita de muitos alunos.

Os dados evidenciam essa problemática, como confirmam os exemplos seguintes, e indicam que o docente precisa investir pesado no ensino da acentuação, pois alguns erros relacionados a isso podem gerar problemas semânticos à informação. A acentuação tem uma função gramatical em algumas palavras, pois marcam a classe morfológica e o significado de algumas delas, como em 'secretária' e 'secretaria', 'e' e ‘é', 'sábia', 'sabia' e sabiá', 'influência' e 'influencia', entre outros pares. Dessa forma, a escola precisa interferir no uso que os alunos estão fazendo da acentuação gráfica (no caso atual, na falta de uso) para alterar a regra por eles estabelecida de que não há mais acentos nas palavras de língua portuguesa, e explicitar que sua função gramatical é um dos caminhos para isso. Exemplos de problemas relacionados a esse microcritério podem ser encontrados na lista seguinte.

$$
\begin{aligned}
& \text { 1aPT046 - "Na sua inteligencia(...)". } \\
& \text { 1aPT047 - "boas notas em sua infancia". } \\
& \text { 1aPT048 - "a leitura influência muito no nosso futuro". } \\
& \text { 1aPT052 - "vai ter muita dificuldades para éscrever" } \\
& \text { 1aPT055 - "A leitura e um jeito de estudar(...)". } \\
& \text { 1aPT058 - "A leitura precisar ser um habito saudavel". }
\end{aligned}
$$

De acordo com os dados, como já mencionado, a ausência de acentuação é o principal problema relacionado a esse microcritério, contudo não é o único. Observa-se também a presença do acento gráfico posicionado de forma equivocada, como há em 1aPT048 e em 1aPT052. No primeiro caso, pode-se explicar o uso do acento gráfico por ele funcionar como marca de tonicidade de palavra, que distingue o verbo 'influencia' do substantivo 'influência'. Isso leva a perceber que o equívoco cometido pelo aluno tem motivação na função distintiva do acento gráfico, o que não se percebe no segundo caso em foco. Em 1aPT052, o acento gráfico é posicionado de forma aleatória em palavra que não requer essa marcação, por apresentar a tonicidade prototípica da língua portuguesa, cuja sílaba tônica preferencial é a penúltima (paroxítonas). 
De acordo com os princípios da $U B L$, são a regularidade e a frequência de uso que levam o indivíduo a estabelecer as regularidades léxico-semânticas e, também, fonológicas das palavras. Assim, quanto mais contato o aluno tiver com as palavras, escritas e acentuadas corretamente, sobretudo as que lhe são mais problemáticas em relação à grafia e à acentuação, mais são as chances de se reverter o quadro aqui descrito. Isso porque, ao aumentar o uso das palavras pelos alunos, esses poderão fixar os padrões e as regularidades formais e de uso dessas, o que faz com que a mente fixe a estrutura correta. Além disso, a Fonologia Baseado no Uso propõe que a palavra é o menor constituinte de análise, por ser provida de significado. É interessante considerar essa noção para o ensino de ortografia, tendo em vista que se o aluno aprender a palavra, e não sílabas ou sons das letras, ele se familiarizará desde o primeiro contato com sua forma de grafia correta, o que pode ajudar a alterar, para melhor, os resultados aqui encontrados e apresentados.

\section{Concordância verbal e concordância nominal}

Além dos problemas relacionados a questões formais da palavra, o macrocritério "Escrita Formal" ainda abarca a simetria de grau e gênero existente entre termos de uma oração. Assim, concordância verbal e nominal também foram investigadas nos dados. $\mathrm{O}$ gráfico 8 mostra que foram contabilizadas 28 redações com problemas de concordância verbal e 19 com concordância nominal, número bem reduzido em comparação a grafia e acentuação das palavras. Aqui será enfocada apenas a ocorrência mais profícua dentre os erros de concordância verbal.

Acerca das ocorrências de problemas com concordância verbal, observa-se que o tipo de erro mais recorrente guarda estreita relação com a acentuação: o verbo 'ter', e seus derivados, conjugado na terceira pessoa do plural, no presente do indicativo 'têm'. Como os próximos exemplos podem demonstrar, a ausência da acentuação, que distingue singular e plural do verbo 'ter' no presente do indicativo, é, recorrentemente, o que gera o problema de concordância verbal.

1cPT013 - “As distrações do século 21 é tudo o que é moderno e que você mais gosta que acaba atrapalhando sua cultura".

1cPT129 - "Eles tem mais línguas (idiomas) que a gente". 
1cPT132 - “(...) índios também tem que nos respeitar."

1cPT138 - "o governo não os valorizam.”

A conjugação de verbos, apesar de ser conteúdo a se trabalhar no sexto ano, é também abordada em séries anteriores, de forma que os alunos já sabem a necessidade de relacionar a pessoa verbal com a forma do verbo, a fim de indicar singular e plural. Os dados indicam que esse é um conhecimento que os alunos do sexto ano detêm, já que realizam essa concordância com sucesso em textos orais. A peculiaridade do verbo em análise é que sua distinção entre singular e plural é marcada pelo acento circunflexo na escrita - com pouca marcação na fala. Os dados demonstram que isso leva o aluno ao duplo erro, já que a ausência da acentuação gráfica leva à falta de concordância entre verbo e seu sujeito.

Nesse sentido, nota-se que problemas na escrita não podem ser pensados e abordados isoladamente, uma vez que a língua não é segmentada. Para tanto, o aluno deve perceber que a divisão do português em vários conteúdos, como é utilizada pela escola e pelas gramáticas, tem a ver com necessidades didáticas e não são o reflexo da língua em uso. No uso, sintaxe, morfologia, pragmática, semântica e fonologia se misturam em prol da comunicação, e isso necessita ser considerado pela escola.

Em relação aos problemas de concordância nominal, esse foi o microcritério menos produtivo. Foram observados 19 textos com problemas dessa natureza, que abarcam tanto concordância de gênero, quanto de número, como se observa nos exemplos a seguir.

1bPT004 - “A leitura pode me ajudar nisso e então é necessário."

1bPT016 - "A leitura talvez seja construtivo."

1bPT019 - "Livros podem ser bom."

Os exemplos sugerem que a distância, na oração, do adjetivo para o substantivo com o que ele deve concordar pode influenciar na concordância nominal, de forma que quanto mais distantes um do outro, maiores são as chances de o aluno se perder em sua construção e cometer erros dessa natureza. Esse tipo de problema pode ser considerado condizente com o sexto ano, já que nessa fase o aluno começa a utilizar, na escrita, estruturas mais complexas, suscitadas, sobretudo, pela tipologia textual argumentativa. Até o quinto ano, a Escola Internacional 
enfatizou em seu currículo a tipologia narrativa, o que justifica o uso de estruturas mais simples, que pouco possibilitavam o afastamento entre termos, como os demonstrados nos exemplos. No sexto ano, fez-se a opção por enfatizar o texto argumentativo, visando, inclusive, a iniciar a preparação dos alunos para os textos avaliativos que farão ao longo de seu percurso acadêmico.

A "Escrita Formal" é a primeira competência a ser avaliada na matriz de correção da redação do ENEM, e isso motivou sua escolha como primeiro macrocritério de análise neste trabalho. Entende-se, aqui, que o domínio da escrita formal da língua portuguesa não tem relação apenas com questões acadêmicas, está ligado também com questões sociais. A escrita fora dos padrões da norma culta, ainda hoje, é estigmatizada socialmente, marcada como característica de classes sociais mais baixas e pouco escolarizadas.

$\mathrm{O}$ avanço do uso da tecnologia no cotidiano das pessoas faz com que o texto escrito seja cada vez mais utilizado como forma de comunicação em redes sociais e mensagens em celulares. Isso faz com que o estigma social do domínio da norma culta escrita fique ainda mais acentuado. É comum encontrar notícias ${ }^{45}$ na rede mundial de computadores que relatem problemas interpessoais motivados por erros de escrita, além de dicas para bem escrever. Esses fatos evidenciam a necessidade de se debruçar sobre o trabalho da escrita formal na escola, sobretudo nas séries iniciais, quando o trabalho com o texto está tomando forma. É importante que a escola interfira diretamente no uso da língua escrita do aluno, possibilitando-lhe situações propícias para que ele aprimore a noção de que língua escrita e língua falada são faces de uma mesma moeda, e não uma única entidade, e, o mais importante, que a escrita tem regras e exigências distintas da oralidade.

\section{4.b.2 Paragrafação}

Optou-se por avaliar, dentro do macrocritério paragrafação, quatro pontos importantes para a organização do texto, que a prática profissional da pesquisadora indica como pontos críticos na qualidade das redações dos alunos do ensino básico. De maneira geral, organizar as ideias em um texto é um dos grandes desafios textuais com o qual a maioria daqueles que já passou por bancos escolares já se deparou. É comum encontrar textos em que não é possível

\footnotetext{
${ }^{45}$ Alguns exemplos disso são manchetes como: "Fim de namoro por causa de erros de português ao se comunicar", disponível em http://www.capixabahoje.com.br/fim-de-namoro-por-causa-de-erros-de-portugues-ao-secomunicar/ acesso em 31 de julho de 2015.
} 
compreender completamente a informação que se tentou transmitir, em razão da ordem em que as ideias foram apresentadas.

Até o final do quinto ano, os alunos da Escola Internacional estão acostumados a produzir narrativas, nas quais os parágrafos são bem marcados pelos acontecimentos da história, além de ser comum a ocorrência de períodos compostos por coordenação, com pouco uso de elementos conectivos e relações simples entre verbos. É nesse momento que os alunos começam a deixar de lado o universo do narrar e começam a entrar em contato com o a arte de argumentar, de defender um ponto de vista.

O texto argumentativo trabalha com a exposição de argumentos e, em alguns casos, com a intenção de influenciar o julgamento do outro (interlocutor) em relação a determinada questão. Além disso, a estrutura textual muda naturalmente, já que os períodos coordenados dão espaço para os subordinados, que são sintaticamente mais complexos para os alunos do sexto ano. Com isso, ante o crescente grau de dificuldade na produção de textos escritos, é comum que a qualidade desses vá sendo comprometida, e que ocorra um alto índice de textos organizados de forma insatisfatória, com problemas que dificultam a coesão, assim como o encadeamento de ideias.

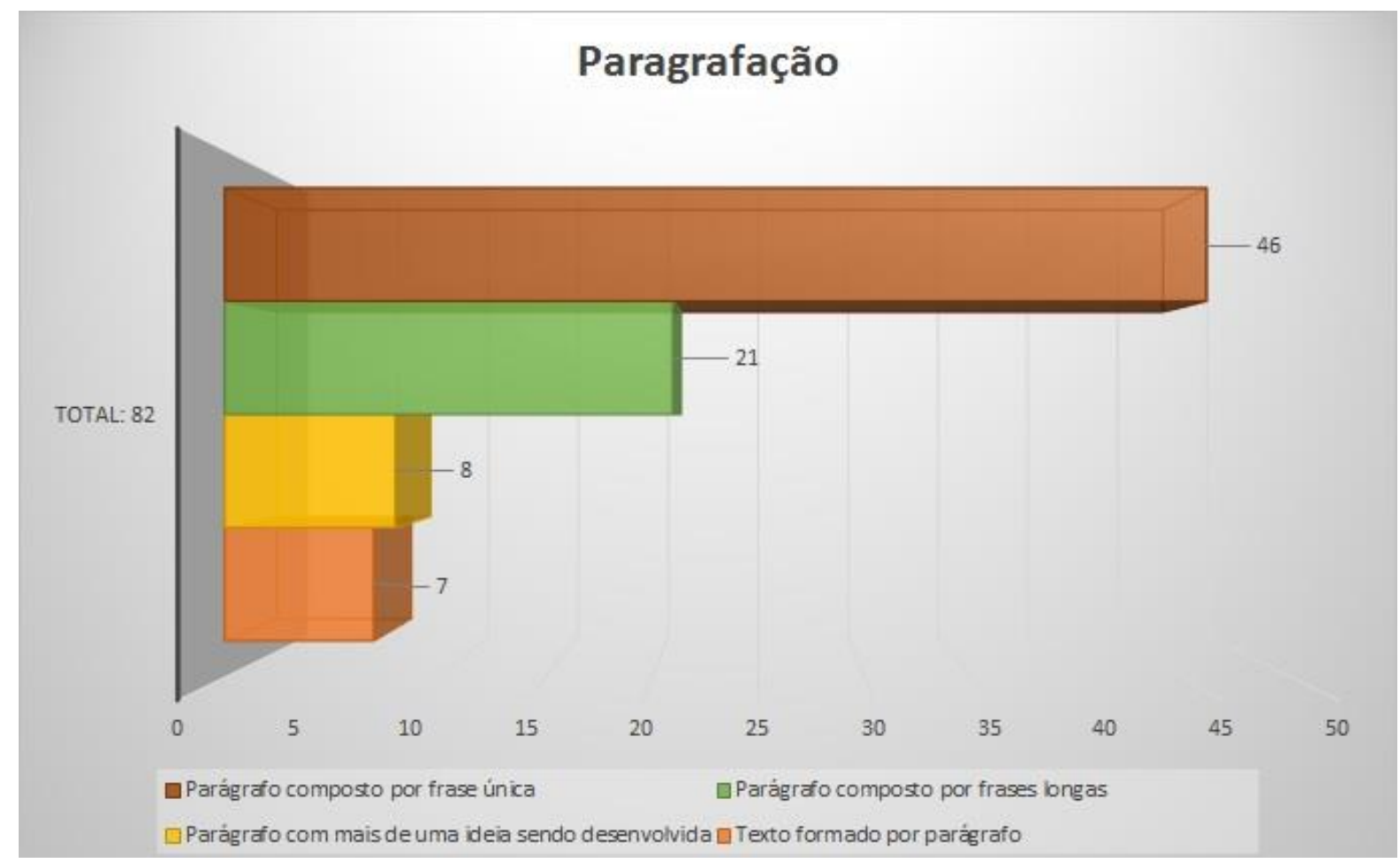

Gráfico 9-Paragrafação 
Considerando-se essas questões, os textos dos alunos foram avaliados, em relação à paragrafação, sob a ótica de quatro microcritérios: (a) Texto formado por um único parágrafo, (b) Parágrafo composto por frase única, (c) Parágrafo composto por frases longas, e (d) Parágrafo com mais de uma ideia sendo desenvolvida. Foram constatados 81 textos com problemas de paragrafação, mais de $50 \%$ do quantitativo analisado, e o problema mais recorrente foi em relação ao microcritério (b), Parágrafo composto por frase única, como indica o gráfico acima, enquanto o problema menos recorrente ficou a cargo dos textos monoparagrafais, o primeiro microcritério a ser apresentado a seguir.

\section{Texto formado por um único parágrafo - Monoparágrafo}

$\mathrm{Na}$ tentativa de defender os argumentos, observou-se que alguns alunos apresentavam textos escritos em que toda a reflexão era organizada nos moldes primários de parágrafo, aqueles feitos sem interrupção no fluxo da leitura, em que se organiza as informações em um único bloco de texto, ou seja, são monoparagrafais. No início da investigação, esperava-se um alto número de ocorrência de textos escritos em um único parágrafo, porém essa expectativa foi frustrada ao se notar que apenas sete, das 150, redações apresentaram o parágrafo único.

A seguir, há a cópia de um exemplar dos textos organizados em um único parágrafo, formado por 19 linhas manuscritas. Tendo-se como base a noção do parágrafo como meio de colaboração com o leitor e a ideia de Bakthin (2002), já apresentada na revisão da teoria deste trabalho, de que quanto mais organizados os textos, maior é a colaboração do leitor, e melhor é a relação entre os interlocutores. Assim, pode-se concluir que os textos monoparagrafais, no sexto ano, indicam que o aluno ainda não tem claro o conceito básico de que o texto é comunicação, e que, por isso, ele - enquanto autor - precisa colaborar com seu leitor, para que esse compreenda facilmente as informações que estão sendo apresentadas e, no caso dos textos analisados, os pontos de vista defendidos.

3aPT046 - Muitas pessoas hoje em dia esquecem de ler por causa da tecnologia usada. Na minha opinião acho que não é errado mecher em celular, tablet e etc... só que elas também não podem se esquecer de fazer suas obrigações como por exemplo dever de casa, tomar banho e ler. Ler é fundamental para o ser humano, aumenta e reforça o conhecimento de cada um. Se você começar a ler desde 
pequeno com certeza absoluta isso vai afetar na sua inteligencia. Não importa o que seja que você está lendo, qualquer tipo de leitura é bom para a sua mente. Então, aqui vai a dica, sempre tentem ler ao máximo possível, se supere, faça uma coisa boa e nunca deixe de fazer suas responsabilidades isso vai te afetar.

Esse texto apresenta um único parágrafo, formado por seis frases, reunindo, em um único bloco, várias informações. $\mathrm{O}$ autor do texto, apenas em um parágrafo, apresenta o tema a ser desenvolvido, expõe o ponto de vista que defende, argumenta sobre ele, propõe um diálogo com o leitor, aconselha-o e conclui sua argumentação. São vários movimentos que o leitor tem que acompanhar para que a interação se processe verdadeiramente.

Outros problemas estruturais podem ser observados, em 3aPT046, além da paragrafação, que serão explorados em outros momentos deste trabalho. Observa-se que a organização no nível da oração é sintaticamente comprometida pela ausência de vírgulas. Já a coesão é prejudicada por repetições de palavras ("tomar banho e $\underline{\text { ler. }}$ Ler é fundamental") e problemas de referenciação (retomada de referencial distante -“ "só que elas também não podem se esquecer"), e, no nível da palavra, há incorreções de grafia (“mecher”) e acentuação (“inteligencia”). Isso só para citar alguns pontos críticos identificados no texto.

Além do fator de colaboração com o leitor, outro ponto da teoria de Bakthin (2002) que vale a pena ser avaliada é no que diz respeito ao tamanho do parágrafo. Conforme já apresentado, o estudioso defende que o parágrafo pode ter a extensão de uma palavra a várias orações. O exemplo acima faz avaliar que a extensão do parágrafo, na escola, deve ser melhor instruída, pois o estudante, em seu momento de aprendizagem, ainda não domina as estratégias necessárias para se elaborar um parágrafo de qualidade, em qualquer das extensões indicadas por Bakthin. Os dados indicam que quanto maior o parágrafo, mais informações ele apresenta, maior as chances de ele ter sua estrutura sintática prejudicada, e, por consequência, sua compreensão será mais difícil para o leitor.

Um ponto a ser observado, no exemplo, é que, apensar de monoparagrafal, o texto não é repetitivo e circular. Isso mostra que o autor tinha, minimamente, conhecimento do tema a ser trabalhado, pois o nível informacional do texto não foi afetado por sua estrutura arbitrária, quando se considera a proposta de redação, e as instruções trabalhadas durante as aulas de Língua Portuguesa, as quais serão abordadas adiante.

Outro dado a se considerar em relação à extensão do parágrafo é que, segundo o princípio da iconicidade da $U B L$, quanto menos o falante/ouvinte conhece a informação, maior 
é a estrutura que a representa. As informações conhecidas, ou seja, o dado, tendem a apresentar pouca informação e uma estrutura mais enxuta.

Uma das primeiras lições ao grupo, trabalhada pela docente, foi sobre o parágrafo do texto argumentativo e a importância de se organizar o texto em mais de um parágrafo. Na faixa etária analisada, em razão de seus conhecimentos da língua escrita, é comum o texto apresentar problemas estruturais, e um dos principais, como será mostrado mais adiante, está relacionado à organização de frases e parágrafos. Como os alunos não dominam as estratégias de coordenação e subordinação de ideias, é comum que utilizem frases curtas em seus textos narrativos. Quando vão argumentar, os alunos do sexto ano, conforme indicam os dados, se esforçam para utilizar estruturas mais complexas, o que, em alguns casos, não dá certo e a organização textual acaba sendo gravemente comprometida.

Por causa do foco nos textos argumentativos que se pretendeu ter com o grupo em análise, a docente optou por parametrizar o parágrafo argumentativo para o grupo. Assim, ficou definido que o parágrafo deveria ter (i) entre cinco e oito linhas manuscritas, (ii) pelo menos duas frases e (iii) desenvolver apenas uma ideia. $\mathrm{O}$ exemplo apresentado anteriormente, que contém um texto monoparagrafal, indica que essas informações sobre o parágrafo argumentativo, ao fim da primeira etapa do ano letivo, ou seja, passados os primeiros dois meses de aula, o conceito e a estruturação de parágrafo careciam de mais investimento pedagógico, ou seja, precisavam ser mais explorados durante as aulas de produção de texto.

\section{Parágrafo com mais de uma ideia sendo desenvolvida}

Outra evidência que comprova as respostas do questionário, apresentadas anteriormente, neste capítulo, de que os alunos têm dificuldade de compreender a natureza abstrata do parágrafo é a produção, em oito redações, de parágrafos compostos por mais de um assunto. Acredita-se que haja relação entre o quantitativo de alunos que produziram textos com a característica em foco e aqueles que indicaram não ter noção alguma da função e da estrutura de um parágrafo. A baixa incidência desse tipo de parágrafos combina, ainda, com a maioria de respondentes que relacionaram a paragrafação com organização textual e com o tema em foco. Dessa forma, se os alunos percebem que em cada parágrafo deve ser desenvolvido apenas um tema, em razão da organização textual, menor será o quantitativo de assuntos por parágrafo. O 
exemplo a seguir apresenta dois parágrafos referentes ao desenvolvimento do texto do aluno, produzido na primeira Etapa do ano letivo.

\section{$3 \mathrm{dPT} 133$}

A maioria dos índios vivem dentro de uma tribo. Cada tribo tem culturas e jeitos diferentes de viver e de se divertir. Já aconteceu muita guerra entre índios e homens brancos causando muitas mortes e doenças desconhecidas.

Não existe uma língua exata para os índios porque à uma variação de 180 línguas. Os mitos mudam, tipos de moradia mudam, regras mudam, etc. (sic).

Nota-se que nos dois parágrafos os temas apresentados não chegam a ser desenvolvidos. O primeiro parágrafo começa com ênfase na moradia dos índios, segue para cultura e fecha com guerra entre índios e homens brancos. Os argumentos são apenas mencionados e agrupados sem critério aparente, embora seja possível relacionar moradia e cultura, ideias das duas frases iniciais.

O segundo parágrafo do exemplo é interessante de ser observado, pois as duas frases que o formam têm seus temas relacionados aos argumentos apresentados, e não desenvolvidos, no parágrafo anterior, mas não apresentam continuidade entre si. Isso leva a perceber que o aluno compreende corretamente a função do parágrafo de agir para a organização textual, e demonstra, ainda, que ele tem consciência de como essa estrutura deve ser desenvolvida. Contudo, seu caráter informacional ainda precisa ser, e será, aprimorado, ao longo das aulas de língua portuguesa.

\section{Parágrafo composto por frases longas}

Outra característica dos parágrafos dos alunos de sexto ano, que envolve questões formais e cognitivas, é a presença, em 21 redações, de frases longas. Nessa fase, o aluno ainda não foi formalmente ensinado a produzir, no texto escrito, frases longas e complexas, com uso de subordinações, verbos no subjuntivo e elementos de conexão. Contudo, como falantes proficientes que são, tentam transpor para a escrita a complexidade de seus argumentos. O 
problema é que, como não estão instrumentalizados para utilizar a linguagem escrita com tal refinamento, acabam formando frases longas, confusas e com problemas formais.

Os alunos estavam, no sexto ano, iniciando trabalho formal com o texto argumentativo escrito, como já foi mencionado, e, portanto, o processo de transpor para o papel argumentos que ainda não estão prontos cognitivamente é altamente complexo. Nesse aspecto, a $U B L$ fornece uma base para que os dados categorizados nos microcritérios $3 b$ e $3 c^{46}$ sejam compreendidos e explicados.

O critério da iconicidade, definido "como a correlação motivada entre forma e função" (Cesário e Cunha, 2013:22), e seu subcritério da quantidade, para o qual "quanto maior será a quantidade de informação, maior será a quantidade de forma para sua codificação" (idem, ibidem) podem lançar luz às razões das longas e confusas frases produzidas pelos alunos em seus textos. Além disso, a complexidade do pensamento acarreta igual complexidade de sua expressão (Clark e Clark, apud Cesário e Cunha, 2013), portanto, dada a complexidade do pensamento dos alunos, em fase de amadurecimento, maiores e mais confusas tendem a ser as frases e os parágrafos. É importante que o docente compreenda esse processo cognitivo para saber lidar com isso e não apenas apontar o erro ao aluno, mas sim ajudá-lo a organizar suas ideias e, consequentemente, seu texto.

Os microcritérios $3 b$ e $3 \mathrm{c}$ não podem ser tratados do mesmo nível que os problemas de grafia, por exemplo, pois não configuram um erro, nessa fase escolar, mas devem ser percebidos como parte do processo de maturação cognitiva. Assim, problemas coesivos dessa natureza precisam ser apontados para serem aprimorados com a intervenção do professor. Isso é importante, também, visto que frases robustas e bem estruturadas não denotam problemas de estruturação do texto, pelo contrário, demonstram que seu produtor possui bom domínio da língua portuguesa escrita. Por isso é importante guiar o aluno na organização de suas ideias, ajudando-o a maturá-las, como já mencionado.

O exemplo a seguir apresenta um parágrafo classificado como $3 \mathrm{c}$, ou seja, é formado por frases longas e, por isso, com problemas de estruturação. Essa produção foi feita na avaliação da primeira etapa letiva, em que o aluno apresentava seu ponto de vista a respeito da situação dos índios no Brasil, motivado pela leitura de livro paradidático sobre o tema, conforme foi apresentado no capítulo anterior.

\footnotetext{
46 3b - Parágrafo composto por uma só frase. / 3c - Parágrafo composto por frases longas.
} 
3cPT132 - A briga entre índios e fazendeiros por causa de território não é boa porque morrem pessoas de ambos os lados, se o território é dos índios os fazendeiros tem que deixar para os índios, mas se é dos fazendeiros, os índios tem que deixar para os fazendeiros. Não é só os fazendeiros e os índios que não se respeitam, o governo também não respeita o índio, pegando seus territórios e vendendo ilegalmente e fazendo dinheiro para si mesmo. (sic)

Em termos estruturais, o excerto tem problemas de Escrita Formal, como concordância verbal, motivada pela ausência do acento diferencial de número do verbo 'ter'. Nota-se, também, a ausência de vírgulas e o uso de conectivos coordenativos de forma equivocada. À parte isso, o aluno utiliza certos recursos refinados, como a inversão do sujeito, em "morrem pessoas de ambos os lados" e orações subordinadas.

No que concerne à argumentação, observa-se que esse aluno organiza o parágrafo em torno da ideia de territorialidade dos povos indígenas, com dois pontos: (i) disputa por território entre índios e fazendeiros e (ii) governo e territórios indígenas. Cada eixo dessa argumentação é apresentado em uma frase que contém a estrutura a seguir descrita. 


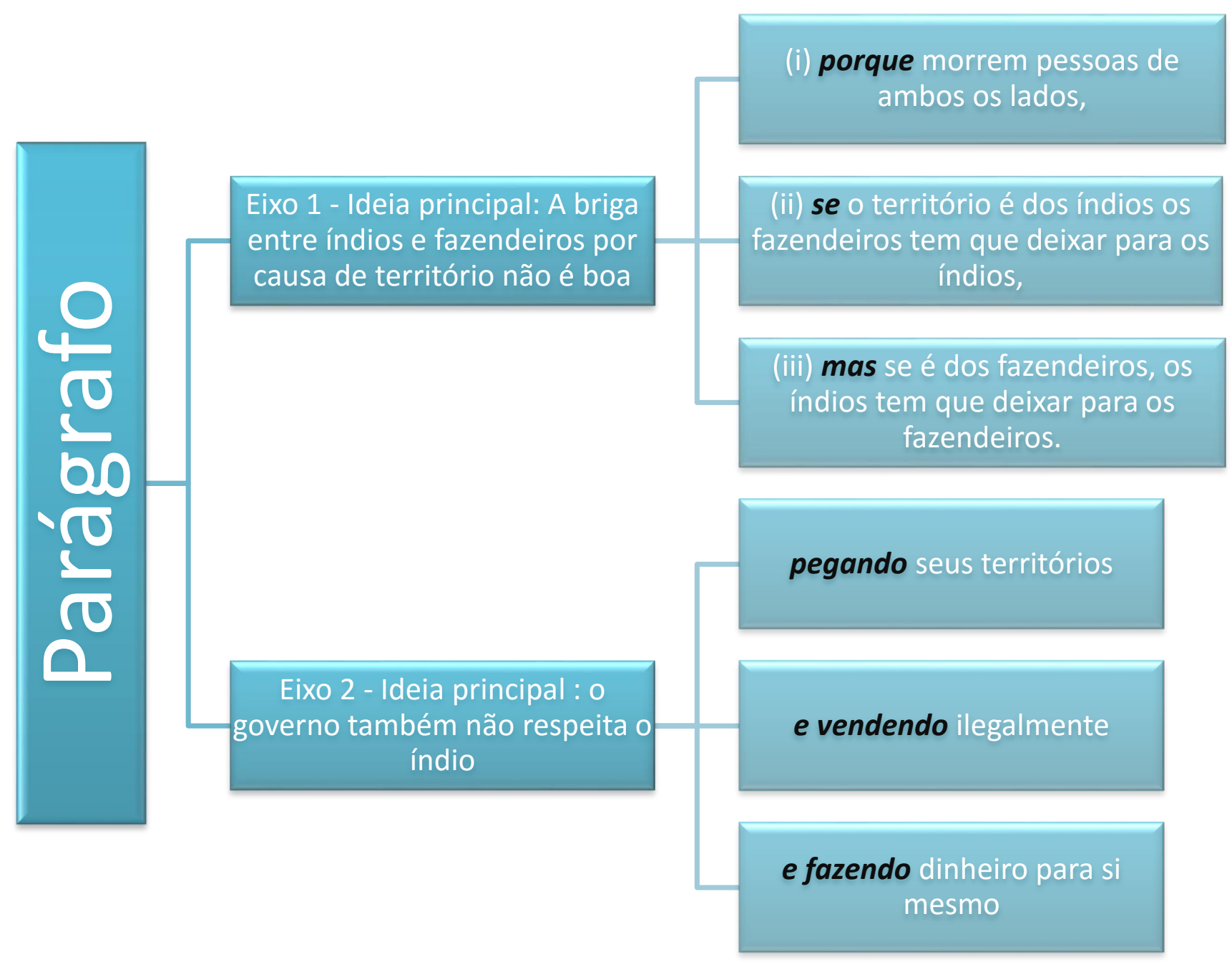

Figura 33 - Parágrafo com frases longas (3c)

Nota-se que o parágrafo foi estruturado regularmente, com três complementos para cada ideia, o que, mais uma vez, demonstra a complexidade do pensamento que se quer expressar. No desenvolvimento do eixo 1, observam-se três argumentos que estão subordinados à ideia principal, e são introduzidos no texto por elementos conectivos, como se pode observar na representação proposta anteriormente. Já as ideias que desenvolvem o argumento do eixo 2 são estruturadas com orações adverbiais reduzidas de gerúndio. Como já mencionado, o exemplo demonstra o uso de estruturas complexas para uma atividade cognitiva complexa: argumentar.

Ainda de acordo com a linha de raciocínio desenvolvida até aqui, acerca da paragrafação, o próximo exemplo sugere um autor com menos habilidade textual que o anterior. Será apresentado o parágrafo de conclusão do texto, em que o aluno se posiciona de forma direta sobre o tema, que é a importância da leitura, proposto na avaliação da segunda etapa letiva. 
3cPT052 - Se você ler muitos livros sobre ação, você provavelmente vai imaginar desenhos e escrever cenas de ação. Na minha opinião se você ler livros de qualidade, com um vocabulario avançado e sobre algum topico que você goste provavelmente vai ter mais facilidade ao escrever textos e a interpretar noticias, livros, textos e redações pois seu vocabulário avançado e seu conhecimento de gramatica vão te permitir ter facilidade com isso.

É possível notar que ele inicia apresentando uma ideia sobre a leitura de textos de ação e fazendo a relação dela com a escrita. A primeira frase é curta, e a ideia central não é desenvolvida e se encerra ao final da frase. A segunda frase é longa e confusa, e se inicia com "na minha opinião", ou seja, o autor anuncia que, a partir dali, deixará seu ponto de vista explícito, e nesse momento do texto ele demonstra como é complexo expor, de forma tão direta, sua opinião sobre a importância da leitura. Isso pode ser confirmado pela extensão da frase, lembrando que quanto mais complexo o pensamento, mais extensa é sua forma de expressão.

A segunda frase do parágrafo tenta relacionar a qualidade da leitura com a facilidade de produzir e interpretar textos escritos, e esses constituem o ponto de vista que o aluno tenta defender. Para explicar essa ideia, ele faz uso de enumerações - como em "vai ter mais facilidade ao escrever textos e a interpretar noticias, livros, textos e redações" - e essa estratégia prejudica a organização do parágrafo, a informação fica confusa e a estrutura fica comprometida, com problemas de regência nominal e verbal, além de apresentar ausência de vírgula antes de termo explicativo. Isso tudo é esperado no texto de um aluno de sexto ano e servirá como indicativo do que é preciso trabalhar com a turma para que comecem a aprimorar sua produção escrita.

\section{Parágrafo composto por frase única}

Como último microcritério da paragrafação a ser analisado, Parágrafo composto por uma só frase foi o que mais ocorrência teve nos dados e constava em 46 dos 150 textos analisados. Esse microcritério, se presente no texto de um escritor maduro e experiente, não será um problema, porém, como já foi mencionado, em textos de alunos do sexto ano merecem atenção especial. Alguns manuais definem a extensão do parágrafo para o aluno, como tendo 
uma ou mais frases, como já abordado no capítulo 1, só que não explicam como essa frase deve ser. Lida de forma superficial, como geralmente faz o aluno de sexto ano, essa característica pode acabar virando um problema, como no exemplo a seguir.

3bPT054 - A importância da leitura para os humanos é muito grande porque as crianças que ficam lendo des que elas são pequenas a inteligência delas são maior e mais eficientes, as crianças que nunca leram quando pequenas não fazem muito trabalho quando pequenas então a inteligência delas não almenta e só diminui. (sic)

Os dados indicam que, quanto maior a frase que um aluno de sexto ano elabora, maiores, também, sãos as chances de que sua qualidade seja baixa, o que é visto no exemplo 3bPT054. Uma das razões para isso, além da apresentada anteriormente, é que, nesses casos, a influência da fala na escrita fica muito marcada, como é possível observar na grafia de palavras como “des", na ausência de concordância nominal em "são maior" e na repetição de termos e ideias.

Ao analisar o exemplo em foco, nota-se que a ideia principal é a primeira a ser apresentada, “A importância da leitura para os humanos é muito grande”, e abre o parágrafo. Tudo o que segue é a justificativa para a ideia de abertura do parágrafo. O aluno tenta desenvolver polos opostos, com efeitos positivos e negativos da leitura, e nisso ele se perde na construção dessa oposição. O esquema a seguir representa a direção argumentativa desse parágrafo. 


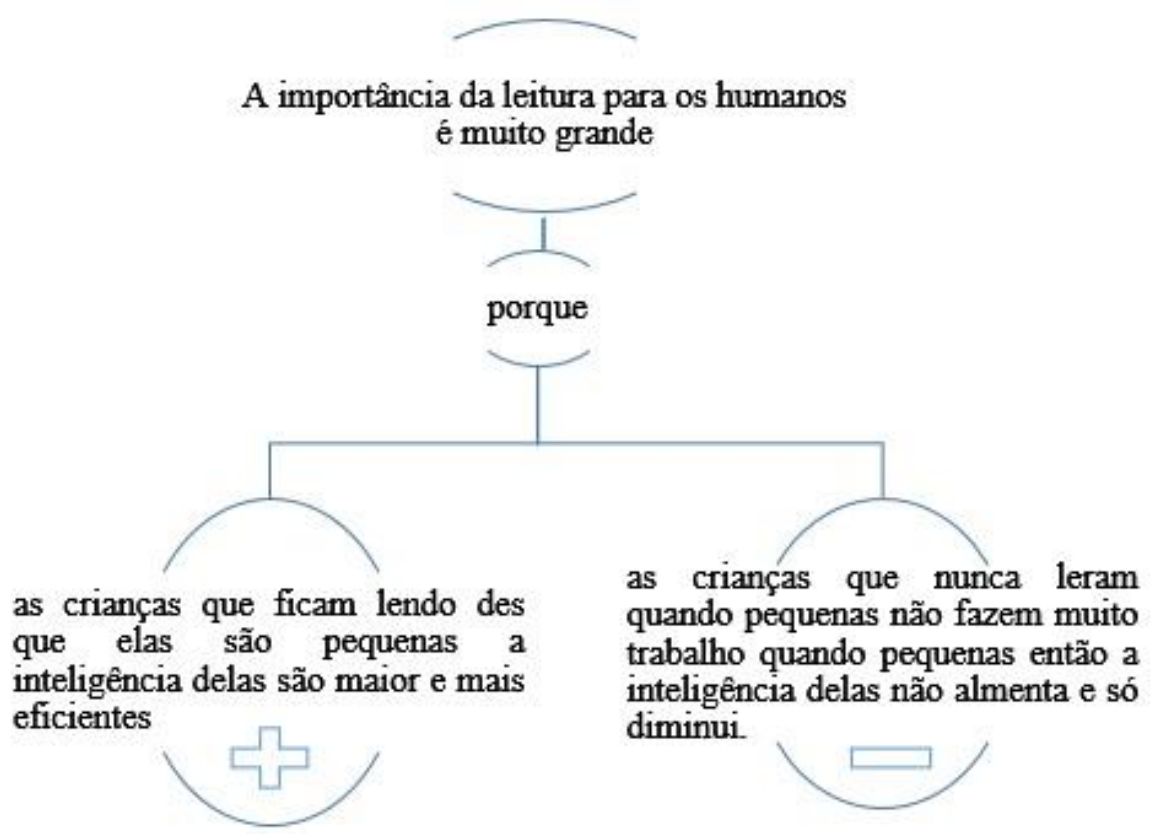

Figura 34 - Argumentação 3bPT054

No esquema, organizou-se a justificativa à ideia principal, como mencionado no parágrafo anterior, em polo positivo, em que as consequências positivas da leitura na vida das crianças são apresentadas, e polo negativo, em que se expõe o que acontece com as crianças que não leem. Nisso, é possível observar que, no polo positivo, o primeiro a ser apresentado, o aluno faz uso da estratégia duplicadora, em uma análise tendo como base a $U B L$, ao retomar o sujeito "criança" em posição em que caberia uma elipse. Assim, o autor marca a referência ao sujeito "as crianças" duas vezes, sempre no plural, com "elas" e "delas" ${ }^{47}$. Essa estratégia não é utilizada quando é feita a argumentação no polo negativo, com o uso da elipse, com retomada do sujeito pela pessoa verbal.

Nesse exemplo, a questão ausência / presença de concordância verbal chama a atenção. O aluno utiliza dois tipos de concordância verbal para o mesmo verbo, 'ser', e o mesmo sujeito, 'a inteligência delas'. Na primeira ocorrência, em que há ausência de concordância verbal, o aluno produz "as crianças que ficam lendo des que elas são pequenas a inteligência delas são maior e mais eficientes". Nesse trecho, tem-se o sujeito no singular, formado por um sintagma nominal "a inteligência delas" e um verbo de ligação no plural seguido de um adjetivo, que

\footnotetext{
${ }^{47} \mathrm{O}$ termo "delas" não funciona como sujeito na frase em análise, mas é uma das estratégias usadas para retomar o sujeito "as crianças".
} 
funciona, segundo a gramática tradicional, como o predicativo do sujeito, alinhado em número com o sujeito que ele caracteriza, mas não alinhado em "eficientes". Retomando a análise do parágrafo anterior, observa-se que, em meio a uma marcação repetida do sujeito pelo uso da estratégia copiadora, e o correto alinhamento verbal, quando há mudança de sujeito, cognitivamente o aluno demonstra não atentar para isso e é nesse momento que ele utiliza um verbo no plural para um recém introduzido sujeito no singular, e, com isso, deixa de fazer a concordância entre verbo e sujeito. Pode-se considerar que o plural do verbo é provocado pela proximidade de “deles", palavra que está no plural.

Em relação à estruturação do parágrafo, as análises apontaram que, independentemente da tipologia do texto a ser produzido pelo aluno, é importante que o professor invista em fazer com que esse conceito fique claro para o aluno, já no sexto ano, e como fazê-lo será tema do próximo capítulo. Como as redações foram analisadas em momentos distintos do ano letivo, acredita-se que o quantitativo de problemas relativos à paragrafação poderia ser maior se intervenções didáticas sobre a estrutura não tivessem sido feitas ao longo das Etapas.

Outro ponto que chamou a atenção da pesquisadora foi que, como anunciado no Capítulo 1 (subseção 1.4.2 O parágrafo no ensino de Língua Inglesa para o sexto ano), os alunos em foco estudaram a estrutura do parágrafo argumentativo nas aulas de Língua Inglesa antes de semelhante trabalho ser iniciado nas aulas de Língua Portuguesa. Assim, era esperado que os alunos fizessem a relação entre as disciplinas, e que percebessem a possibilidade de usar a estrutura ensinada para a língua inglesa nos textos produzidos em língua portuguesa. Contudo, isso não aconteceu, e conversas entre a pesquisadora e a docente da disciplina de Língua Inglesa revelaram que o grupo não demonstrava tanta dificuldade nas aulas deste idioma quanto evidenciavam as redações em Língua Portuguesa. Ou seja, além de não haver a transferência de saberes esperada, há indícios de que a metodologia proposta pelo currículo internacional é mais eficiente, no caso dos parágrafos argumentativos, do que o ensinado, na EI, no currículo brasileiro. Em relação ao currículo nacional, vale lembrar que a proposta de trabalhar a produção de textos argumentativos no sexto ano foi da docente responsável pelo ensino do português e não da instituição e (ou) do material didático adotado.

$\mathrm{Na}$ reflexão sobre os resultados do macrocritério Paragrafação, os 46 textos que apresentaram parágrafos formados por uma só frase foram abaixo da expectativa da pesquisadora. Com base em sua experiência como corretora de redações em diversos níveis e modalidades de ensino, ela pressupunha, no momento do desenho desta pesquisa, que esse problema estaria presente em torno de 90 das 150 redações analisadas, o que não aconteceu. $\mathrm{O}$ 
que convergiu com a expectativa inicial da pesquisa foi a qualidade dos erros identificados, principalmente, nos parágrafos marcados com 3b e 3c, e essas continuarão a ser analisadas, com mais profundidade, nos macrocritérios que serão explorados das próximas subseções.

\section{4.b.3 Coesão}

A coesão é fundamental para um texto escrito, e também falado, ser considerado de qualidade. Ela pode ser a responsável pelo sucesso ou fracasso da comunicação, já que é ela que conecta as informações e transforma possíveis sentenças isoladas em textos fluidos organizados. Sendo assim, é fundamental que a coesão conste da análise desta pesquisa, já que se intenciona mapear os erros dos alunos de sexto ano, em suas produções de textos escritos, para propor estratégias didáticas para o aprimoramento dessa prática.

Conforme mencionado no Capítulo 1, Halliday e Hasan (1976 [2013]) percebem a coesão como parte do sistema da língua, portanto é ligada, também, à microestrutura do texto, ou seja, da estrutura linguística que o compõe. Por isso serão avaliados neste macrocritério elementos da gramática normativa que influenciam diretamente na coesão de um texto, como os conectivos responsáveis pelas estruturas de subordinação e coordenação de orações. Os alunos do sexto ano não trabalharam esses conteúdos gramaticais em seus estudos até então, o que mapeará o uso desses elementos sem a interferência didática, exceto em alguns casos ligados à coesão referencial.

A exposição dos dados e suas análises serão organizadas de acordo com as duas modalidades de coesão indicadas por Koch (2004 e 2007): referencial e sequencial. Como último microcritério, serão apresentados os resultados referentes a "Truncamento", que podem envolver questões concernentes às duas modalidades de coesão.

No total, foram identificadas 281 ocorrências de problemas relacionados à coesão, dos quais 144 são relativos à coesão referencial e 88 à coesão sequencial. Isso demonstra que evitar a repetição de palavras e fazer referências no texto, para os alunos em foco, é um movimento cognitivo complexo, como se tomou como pressuposto desta pesquisa. Acredita-se que os problemas coesivos nos textos analisados sejam coerentes ao contexto de ensino dos alunos, principalmente ao se considerar a idade deles. O gráfico a seguir apresenta os resultados numéricos da análise do macrocritério em foco. 


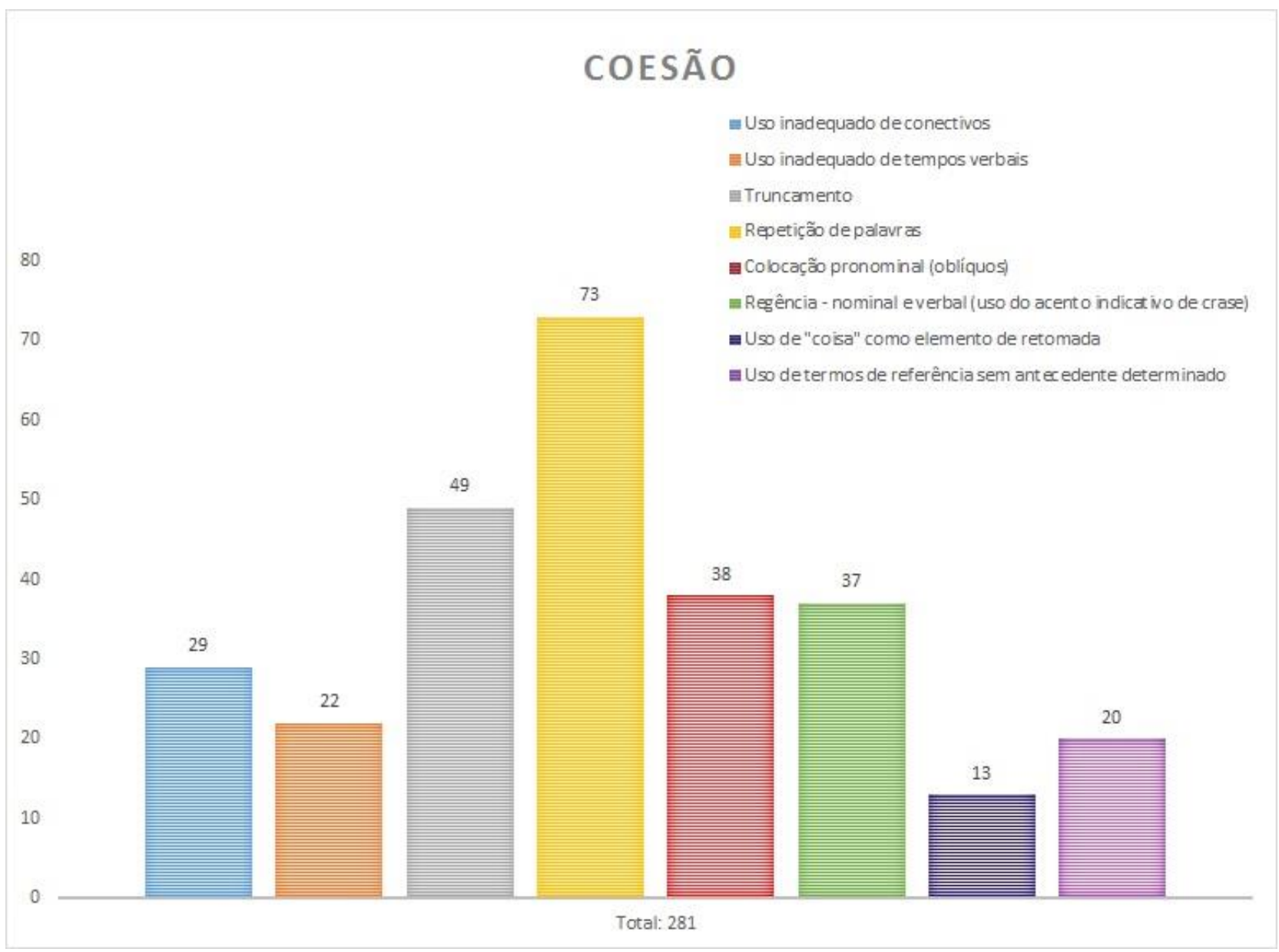

Gráfico 10 - Coesão

Conforme se pode observar no Gráfico 8, o erro mais recorrente foi a repetição de palavras, que esteve presente em 73 produções de texto, seguida pelos problemas relativos ao truncamento de informações. A menor incidência foi relativa ao uso do termo "coisa" como retomada, o que foi contra a hipótese inicial de que esse recurso estaria presente com grande frequência nas produções analisadas. Vale ponderar que a repetição de palavras em um parágrafo, principalmente se feita com planejamento pelo escritor, pode imprimir, ao discurso, efeito de ênfase. Contudo, os alunos do sexto ano, em sua maioria, não têm condições de utilizar sozinhos esse recurso textual. Por isso a repetição da palavra nesse contexto acaba atrapalhando a fluidez das informações e comprometendo a coesão do texto. Isso justifica a inclusão desse microcritério analítico, nas investigações concernentes à coesão textual. 


\section{Coesão referencial}

A coesão referencial está relacionada à superfície textual e diz respeito aos mecanismos de se evitar que uma palavra se repita intensivamente em um texto completo ou em trechos dele. A referência pode ocorrer por anáfora, retomando-se uma informação já mencionada, ou catáfora, introduzindo-se um elemento novo ao texto. A língua portuguesa oferece alguns recursos referenciais que podem ser trabalhados com os alunos do sexto ano, como as relações de hiponímia, hiperonímia e sinonímia, e os pronomes de maneira geral.

\section{a) Repetição de palavras}

Os dados revelaram que, como se poderia esperar, os alunos do sexto ano apresentam grande dificuldade de trabalhar, nos textos produzidos por eles, a referência, uma vez que as atividades de leitura, em sala de aula, indicaram que esses estudantes conseguem perceber as relações de referência com facilidade. Não é por acaso que 73 redações apresentaram problemas de repetição de palavras, como é observado no próximo exemplo.

4dPT072 - Essa história é bem interessante porque conta uma história que foi diferente de tudo que eu já li, é uma historia emocionante, e cheia de detalhes. $\mathrm{O}$ texto é bem estruturado porque ao contrário de umas histórias ele explica bem e não é tão sem graça. Eu mudaria na história a última parte, porque poderia falar se ela morre ou não para continuar a história. Eu recomendaria está história para álguem que gosta de histórias emocionantes.

O trecho acima é representativo de mais de um microcritério relacionado à coesão referencial. A repetição do termo "história" é bastante proeminente, pois, em um parágrafo, há oito ocorrências desse termo. Nota-se que a "história" é o assunto do parágrafo, sobre o que a ideia está sendo desenvolvida, e isso pode justificar a necessidade de o aluno utilizar, repetidamente, esse termo.

Outra questão a se considerar é que "história", no parágrafo analisado, tem duas acepções, uma geral, relativa a qualquer história, e outra específica, direcionada ao enredo do 
livro sobre o qual o aluno se posicionava. Isso pode ter contribuído para que apenas essa estratégia tenha sido usada, ao invés de usar o nome do livro, por exemplo, para evitar o termo "história".

É interessante observar como a coesão é afetada em casos como o apresentado em 4dPT072, uma vez que a repetição da palavra diminui o ritmo da leitura, interrompendo a fluidez das informações. Vale considerar, também, que a grafia desse termo é regular, mesmo com um acento agudo esquecido em uma das ocorrências, o que reforça a ideia vista em relação à Fonologia Baseada no Uso de que quanto mais usado um item, mais regular ele fica na língua e, consequentemente, menos variações ele apresentará. No caso do texto escrito, essa variação pode significar erro de grafia.

Ainda nesse exemplo, observa-se que o aluno tenta usar elementos de referência, com êxito em algumas das tentativas, como em "O texto é bem estruturado porque ao contrário de umas histórias ele explica bem e não é tão sem graça". Observa-se nesse trecho que o pronome pessoal "ele" para retomar, com sucesso, o termo "o texto", além da elipse desse mesmo termo na oração coordenada seguinte. Já em "porque poderia falar se ela morre ou não", nota-se que o uso do pronome pessoal “ela” foi realizado sem referente próximo, de forma que não há como retomar "ela" e saber o que representa na frase.

Nota-se também que, mais uma vez a influência do texto falado se faz presente na produção escrita, já que a repetição de termos também é uma marca da oralidade, pois, na fala, o uso intensivo de uma única palavra nem sempre é percebido, e pode ser corrigido. Sobre isso, vale lembrar que, no ENEM, marcas de oralidade são penalizadas na Competência 1, e podem diminuir, ou até zerar, a nota do participante.

Ainda sob a perspectiva da análise do exemplo anterior, acerca de a repetição da palavra ser motivada pelo tema, o exemplo a seguir segue nessa mesma direção, já que o termo repetido "Hanako" também é o assunto do parágrafo.

4dPT080 - Os personagens principais desse livro são Aiko e Maria (pais de Hanako), Mieko e Yoshiko (irmãs de Hanako). O problema central dessa história é a doença de Hanako.

Nesse exemplo o fato de "Hanako" ser também a personagem principal da história pode colaborar para a repetição do termo. Vale comentar que esse exemplo representa várias produções de texto, pois a repetição do nome da personagem central do livro foi recorrente nos 
dados. A relação do alto número de ocorrência do nome Hanako também pode indicar que termos com a característica de representar um "ser animado" tendem a ser repetido várias vezes em um texto.

\section{b) Colocação pronominal}

O segundo microcritério mais produtivo foi em relação à colocação pronominal. Os dados indicaram que os alunos têm noção de que o pronome substitui um termo e pode ser usado para favorecer a coesão textual, contudo as regras de uso dos pronomes oblíquos não lhes são familiares. Assim, conforme era esperado, é comum os alunos do sexto ano usarem o pronome pessoal como objeto direto e preferir a próclise à ênclise, como é comum no português do Brasil. Esse tipo de erro é de natureza sintática, que fica mais comprometida que a coesão, tendo em vista que é possível recuperar o referente dos termos substituídos pelos pronomes. Os trechos a seguir ilustram essas ocorrências.

4ePT011 - “então nunca é tarde demais para pegar um livro e começar a ler ele".

4ePT017 - "Lendo, você nunca vai machucar ninguém, mas ajudar ela".

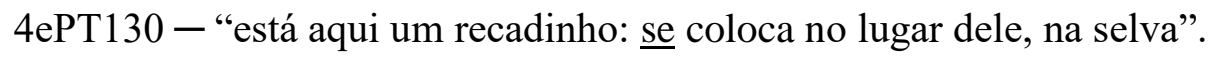

Além dos casos apresentados, outro uso de pronomes oblíquos nos dados é a transformação de verbo transitivo indireto em verbo pronominal, especificamente do verbo 'tratar'. Essa ocorrência se deu na proposta de produção 3, sobre o livro "Não se esqueça da rosa", questão já abordada no capítulo anterior, quando os alunos iam apresentar o tema da leitura, para apresentar a história e sua opinião sobre ela. A frase pretendida era algo como: o livro trata da história de Hanako. Porém, esse verbo foi usado em sua forma pronominal "tratarse", mesmo apresentando sentido diferente de sua forma sem pronome.

4ePT109 - "O livro se trata (...)".

4ePT110 - "Esse livro se trata (...)".

4ePT078 - "Ele se trata (...)". 
4ePT079 - Esse livro trata-se (...)".

A frequência nos dados demonstra que é comum, aos alunos em foco, ampliar o uso do verbo pronominal, aplicando-o também quando o verbo deveria ser usado em sua forma transitiva indireta. É importante, portanto, enfocar, durante as aulas, estratégias para que os alunos não comprometam a estrutura de seus textos escritos com equívocos dessa natureza. Apenas indicar o erro não é suficiente, pois o aluno precisa alterar seu uso da língua de forma consciente, principalmente em casos como esse.

\section{c) Uso de termos de referência sem antecedente determinado}

Um problema que interfere mais na coesão textual que em sua sintaxe é o relativo ao microcritério 4i: uso de termos de referência sem antecedente determinado. Isso compromete significativamente o desenvolvimento do texto, pois faz com que a informação esteja incompleta e não seja compreendida pelo leitor, como no exemplo a seguir.

4iPT010 - Fizeram pesquisas falando sobre a leitura. E nessas pesquisas eles fizeram testes com crianças da Inglaterra para ver se lendo desde pequeno irá ajudar no futuro.

Observa-se que o termo em negrito não apresenta referente no texto, nem nesse, nem em trechos anteriores. $\mathrm{O}$ autor do trecho, na verdade, introduz uma nova informação com o pronome pessoal utilizado, contudo a natureza dos pronomes pessoais impede que a estratégia pretendida tenha êxito, embora o contexto esclareça que o termo "eles" signifique os cientistas que "fizeram testes com crianças na Inglaterra". O problema de contar, no texto escrito, apenas com o contexto para que o leitor compreenda a informação é uma estratégia arriscada, pois o leitor, guiado pela estrutura, pode não fazer as conexões de sentido necessárias para o sucesso da comunicação pretendida.

O exemplo seguinte apresenta o primeiro parágrafo de um texto, cujo título é "Leitura". Claramente o autor deste trecho inicia o texto retomando o título, pois a primeira palavra do primeiro parágrafo é "Isso", um elemento anafórico, como se pode verificar a seguir. Assim, 
novamente o contexto é o responsável por desfazer a possível falta de informação causada pela falta do referente do pronome demonstrativo "Isso".

4iPT024 - Isso influencia no crescimento do ser humano porque ajuda ele a ter um bom futuro. Ele pode arranjar um bom emprego, estudar lá fora, quem sabe?!

Ainda nesse exemplo, nota-se que o autor conta com a colaboração do leitor também quando emprega "estudar lá fora”, em que "lá fora” é um recurso exofórico, pois se refere a um espaço fora do texto, para o qual não existe referência textual. Nesse momento, o autor conta com o conhecimento de mundo do leitor para que esse compreenda que, culturalmente, "estudar lá fora" significa estudar em outra localidade daquela em que reside, podendo ser outra cidade, estado ou país, fora do Brasil. Como se pode perceber, o leitor precisa fazer um esforço extra para compreender a informação, e, infelizmente, nem sempre se pode contar com uma leitura colaborativa por parte do interlocutor.

Nos dois casos representativos dos problemas encontrados em relação a elementos de referência sem antecedente expresso na estrutura do texto, nota-se que, por ser parte do sistema da língua, a coesão é usada pelos alunos, ainda que de maneira equivocada, sem a necessidade de um estudo formal sobre isso. Assim, caberá à escola ajudar o aluno a organizar mentalmente os recursos de referenciação que a língua oferece a fim de construir um bom texto escrito.

\section{d) O uso de COISA}

Como último recurso acerca da coesão referencial aqui observado, tem-se o uso do termo "coisa" como elemento de retomada. Na verdade, o rótulo dado a essa categorização não está adequado, o que já demonstra que as expectativas quanto a esse microcritério foram quebradas pelos dados. Não seria o uso de "coisa" como elemento de retomada, mas de referência, e o problema, nos dados, é justamente a que essa palavra se refere nas 13 redações em que ela foi identificada. O exemplo a seguir, traz dois pontos a serem discutidos aqui. 
4gPT033 - A leitura faz agente se consentrar na hora da prova, teste e quis. A leitura faz coisas extraordinárias. A leitura faz agente ser educado, e com a leitura encina coisas novas, tipo, palavras, falar serto, a consentrar, etc.

Nesse trecho, observa-se que, em sua primeira ocorrência, "coisa" apresenta um caráter generalizante, recorrente nos dados. Uma hipótese é que diga respeito à intencionalidade discursiva, na qual se pode entender que a intenção do autor seja realmente de não especificar as "coisas extraordinárias" causadas pela leitura. Outra possibilidade de analise pode associar “coisas" à imprecisão vocabular causada por uma limitação compreensível, coerente com a fase escolar dos alunos de sexto ano, na qual o autor tem muitas ideias, mas não sabe como transpôlas para o texto escrito.

A segunda ocorrência do termo "coisas" também não é feita com a intenção de retomar informações, mas sim de apresentar novos elementos ao texto, naquele trecho, sendo, portanto, um recurso catafórico. O autor explica o que são as "coisas novas" que a leitura ensina, e isso é introduzido, no texto, pelo termo "tipo", que marca que, a partir daquele ponto, será explicado o que o termo "coisas novas" significa.

No exemplo 4gPT036, a seguir, pode-se observar mais um uso do termo "coisa". Nele, essa palavra é utilizada na tentativa de especificar, ou caracterizar, o termo que predica (nos dois casos, "coisa "faz parte do predicativo do sujeito), no caso, "a leitura".

4gPT 036 - A leitura é uma coisa que usamos desde que aprendemos a falar, até o dia que morremos. Usamos ela tanto que as vezes nem percebemos. A leitura traz benefícios, como: Raciocínio, interpretação e vários outros. Por isso, a leitura é uma coisa fundamental para a nossa vida.

O mini Aurélio, dicionário da Língua Portuguesa, define coisa ou cousa como "1. o que existe ou pode existir; 2. objeto inanimado; 3. acontecimento, ocorrência; 4. matéria; 5. Popular, indisposição indeterminada, troço; e 6. Popular, qualquer objeto, troço". São seis definições de valor impreciso e generalizante, que combinam com o valor com o que foram utilizados nos textos em foco, e que justificam seu uso, mas não colaboram para a compreensão do leitor, nem para a coesão textual. 


\section{Coesão sequencial}

A coesão sequencial está ligada à microestrutura do texto, e erros dessa natureza geram problemas estruturais para a composição, comprometendo a qualidade da redação. Em geral, os problemas ligados à coesão sequencial são conteúdos abordados na escola em anos superiores ao sexto, e a análise proposta tem o objetivo de mapear o uso desses elementos pelos alunos nessa fase escolar.

\section{a) Regência nominal e regência verbal}

Os desvios produzidos pelos alunos de sexto ano e relacionados à regência, seja ela de natureza verbal ou nominal, têm influência da fala, na medida em que, cotidianamente, muitas pessoas não se preocupam com esse aspecto em suas comunicações. É comum ouvir regências equivocadas, que são capazes de soar corretas para alguns falantes nativos da língua portuguesa. Como exemplos desses casos, pode-se considerar frases como 'assistir o filme' (por assistir ao filme), 'você está aonde' (por você está onde?), ‘ele visa o sucesso' (por ele visa ao sucesso), entre outras possibilidades.

Dessa forma, é importante perceber que o papel da sala de aula, em postura alinhada aos PCN, é aproveitar a língua falada levada de casa para a escola, pelo aluno, e proporcionar condições de adequá-la à modalidade padrão da língua portuguesa. Nesse caso, é importante mostrar ao aluno os equívocos cometidos e apontar-lhe o caminho a ser seguido. Assim, no caso da regência, apenas indicar, nas produções de texto, os desvios da norma padrão pode não ser eficaz; é preciso trabalhá-la também nas produções de texto em que se usa a modalidade falada da língua.

Os dados analisados apresentaram 37 ocorrências de problemas dessa natureza, o que é um quantitativo adequado ao sexto ano. Em geral, os alunos nessa fase escolar tendem a utilizar um vocabulário simples em seus textos, o que lhes proporciona mais acertos do que erros. Quando há problemas de regência, eles geralmente vêm acompanhados de motivações como ausência do acento indicador de crase, o que, segundo os dados indicaram na análise da acentuação, é frequente na escrita do público alvo. Nesse caso, é difícil delimitar a real natureza 
do problema, pois não foi possível concluir, a partir dos dados, se esse é um desvio relacionado à regência ou à acentuação.

4fPT042 - Então ler, é uma grande importancia para o ser humano em relação a comunicação.

4fPT022 - Quando lemos uma história que você gosta muito, você imagina que é o ator principal e vai ter muita diversão.

4fPT028 - Tenho certeza que você vai reclamar, mas talvez quando você começar a ler você goste do livro.

4fPT036 - As pessoas andam cada vez, mais desinteressadas na leitura.

4fPT043 - "você fica mais informado ao que tem em sua volta".

4fPT102, 4fPT106 - "Por causa que"...

Além da influência da fala, a regência pode ser considerada uma estrutura de nível complexo da linguagem. Os exemplos anteriores apresentam desvios relativos à regência que poderiam passar sem serem percebidos por grande parte da população brasileira. Contudo, é importante valorizar o estudo sobre esse tema, pois um equívoco dessa natureza pode comprometer a estrutura e a semântica de alguns textos, já que alguns verbos têm seu significado alterado de acordo com a preposição que os acompanha, como assistir. Dessa forma, trocar a preposição provoca também alteração de sentido, o que provoca um problema de coesão e de compreensão da informação e, consequentemente, prejudica a comunicação.

\section{b) Uso inadequado de conectivos}

Recurso importante para a coesão textual, os conectivos são imprescindíveis para a organização das ideias. Além disso, é fundamental considerar esses termos para a estrutura da língua, pois são eles os responsáveis pela relação de subordinação e coordenação entre orações e termos. Podem funcionar como conectivos: conjunções, preposições, pronomes e advérbios.

Por ter seu uso intimamente relacionado a períodos compostos, não é esperado que os alunos de sexto ano usem com frequência esse recurso coesivo, nem que eles, ao utilizarem tal recurso, tenham um repertório variado de conectivos. Nos dados, 29 redações apresentaram 
problemas dessa natureza, o que pode provocar equívocos no nível do significado se for utilizado o conectivo errado. Os dados indicam que, em geral, os erros ligados a esse microcritério têm duas naturezas: (i) a grafia equivocada do termo "mas" e (ii) o posicionamento do conetivo em lugar errado, como é possível verificar no exemplo abaixo.

4aPT038 - As crianças que não desenvolvem um hábito de leitura não desenvolvem o mesmo vocabulário que as crianças que leem muito, além disso.

Mais uma vez, os dados apresentam uma dupla interpretação de um desvio da norma padrão no uso de "mais" por "mas", na organização das ideias. As dúvidas são: atribui-se a esse tipo de erro a natureza ortográfica ou coesiva? Considera-se o uso de um adverbio no lugar de uma conjunção, ou se acredita que o aluno escreveu "mas" de forma errada "mais"?

$\mathrm{Na}$ tabulação dos dados, os equívocos relacionados ao uso de "mais" por "mas" foram computados como erro de coesão, porém há a pergunta sem resposta, aqui, sobre essa análise. Quanto ao posicionamento do conectivo na sentença, observou-se que isso acarreta problemas estruturais à frase, além de comprometer seu sentido. Nessa situação, não há dúvidas quanto à natureza coesiva do problema, que deve ser trabalhado em sala de aula.

\section{c) Uso inadequado de tempo e modo verbais}

Outro problema relacionado à coesão sequencial e considerado aceitável para o sexto ano é o uso inadequado de tempos e modos verbais. Esse desvio à norma padrão é uma questão que se estende por vários níveis de ensino, e é encontrado, inclusive, em textos profissionais. Trata-se da dificuldade de se alinhar, sobretudo, os modos verbais em uma sentença. O resultado dessa dificuldade é a produção de frases confusas, que podem ser ininteligíveis, dependendo da combinação verbal feita.

O modo subjuntivo apresenta algumas especificidades em relação ao modo indicativo, e, geralmente, está presente em orações subordinadas. Quando há o uso do modo subjuntivo em uma oração dessa natureza, ainda que deslocada de sua posição prototípica, o verbo da oração principal deverá estar no modo indicativo. 
O subjuntivo se mostra próprio de uma estrutura complexa da língua portuguesa, e seu uso atrelado à subordinação corrobora essa característica. Dessa forma, não se podia esperar um uso frequente desse modo verbal entre os alunos do sexto ano, tampouco que esse uso, quando ocorresse, fosse bem-sucedido. O fato de os alunos se aventurarem no uso do subjuntivo em textos escritos demonstra que o processo cognitivo relacionado à prática da língua está em desenvolvimento. Dessa forma, as 22 redações que apresentaram problemas dessa natureza representam um quantitativo baixo no corpus em análise.

Os exemplos a seguir ilustram a principal dificuldade dos alunos em relação ao uso do subjuntivo: o já mencionado alinhamento entre verbo da oração principal e verbo da oração subordinada. Nota-se que o uso do subjuntivo guarda também relação com a tipologia dos textos produzidos pelos alunos. Os textos argumentativos demandam do usuário da língua estruturas mais complexas que os narrativos, e os alunos em foco começaram a produzir textos com críticas e defesas de ponto de vista no sexto ano.

4bPT007 - O que fez com que muitas pessoas param de ler? // Quando $\underline{\text { crescermos, }}$ pode ser que esquecemos muito do que aprendemos.

4bPT013 - Vamos botar a sua cabeça para pensar, se tudo tecnológico e moderno não existisse, mas ainda existiria tudo da época do seu pai, você seria mais culto ou menos culto? Você ja sabe a resposta.

Os exemplos demonstram que o modo verbal em foco é comum à fala dos alunos, tanto que tentam transpô-lo para a escrita. Porém, na fala espontânea, a organização textual é automática e, por vezes, a necessidade de combinação entre as estruturas não é percebida. No texto escrito, a organização das ideias é mais complexa, o que gera a dificuldade de se combinar os modos verbais corretamente.

Um fator que se deve considerar nesta análise é que o modo verbal é conteúdo do sexto ano, porém planejado para ser ensinado no último bimestre letivo. Isso é mais um indício de que o aluno não tem conhecimento formal de como se utiliza o modo verbal em questão, assim ele conta, até o momento em que as produções de texto foram realizadas, apenas com sua intuição de falante nativo, que, como se pode verificar, não é suficiente para o correto uso do subjuntivo. 


\section{Truncamento de informações}

O truncamento de informações é um problema grave para a estrutura do texto, pois, como o próprio nome sugere, a organização da frase é comprometida a ponto de deixar a informação pouco ou nada compreensível. No sexto ano, esse tipo de problema é previsível, e ocorreu em 49 redações.

Uma informação pode estrar truncada se a frase é escrita com um verbo sem complemento (sujeito, predicativo ou objetos) na suposição de que o leitor compreenderá a parte omitida. Outras formas, já analisadas neste trabalho, são o uso de pronomes demonstrativos com problema de referente e a pontuação - ausência ou presença em local indevido (a pontuação é foco da próxima subseção). É importante mencionar que esses casos foram analisados com base em microcritérios próprios e não foram contabilizados como truncamento.

A falta de paralelismo sintático também pode truncar uma informação, mas essa não foi alvo de análise, já que está fora do alcance dos alunos de sexto ano. Além das estruturas apresentadas, orações subordinadas sem a principal, como é possível ver em 4cPT059, e presença de adjuntos adnominais sem o nome para ser caracterizado também estão entre os problemas relacionados a truncamento de informação.

Os exemplos a seguir apresentam poucos casos de truncamento. Neles, pode-se observar a presença de uma oração subordinada adverbial "Quando você assiste um filme (...)" construída como frase e, portanto, separada de sua oração principal. Além disso, há termos incompletos, que prejudicam a compreensão da leitura, como em "Você percebe que é bem melhor". Fica a pergunta: o que é "bem melhor”? Há, na oração subordinada, duas possibilidades de referente para o "bem melhor", assistir a um filme ou ler um livro. Esse tipo de problema está presente em outros termos, que estão sublinhados no exemplo 4cPT059, e demonstram como é complexo o processo de destruncar ${ }^{48}$ a informação. O exemplo 4cPT012 ilustra a falta de complemento de um termo, nota-se, claramente, que há uma lacuna na frase, sobretudo no que foi sublinhado.

\footnotetext{
${ }^{48}$ É sabido que essa palavra não faz parte da língua portuguesa, mas pareceu apropriada para a informação que se quer comunicar.
} 
4cPT059 - Nunca é tarde para gostar de um bom livro. Quando você assiste um filme e depois lê o livro. Você percebe que é bem melhor, pois parece que você faz parte do livro e sente as emoções. Parece até que você está no lugar, presente. É bem melhor ler o livro do que ver o filme.

4cPT012 - A leitura é uma das mais preciosas do mundo.

Os problemas de truncamento podem refletir o fluxo e os pressupostos do texto oral, e algumas hipóteses sobre o que erros dessa natureza podem representar são: (i) a dificuldade de o aluno organizar seu pensamento no texto escrito e (ii) a presença de uma complexa atividade cognitiva na formulação de uma argumentação. A certeza, em relação a esse microcritério, é a de seu prejuízo ao texto escrito, já que pode inviabilizar a compreensão por parte do leitor. Por isso, o truncamento de informações precisa ser muito bem investigado e trabalhado didaticamente, para que os alunos, em qualquer nível de ensino, possam minimizar esse problema e produzir textos escritos de qualidade.

\section{4.b.4 Pontuação - comparação entre os dados escritos e o corpus III}

A pontuação, conforme já foi detalhado na revisão teórica deste trabalho, é um dos recursos linguísticos em que se evidencia a relação entre língua falada e língua escrita. No macrocritério Escrita Formal, essa dupla foi analisada no nível do segmento; no Paragrafação, iniciou-se a análise no suprassegmento; e, no macrocritério Pontuação, a relação entre fonologia e sintaxe ficará mais evidente, pois buscar-se-á analisar se e como os alunos de sexto ano utilizam tal recurso linguístico para relacioná-lo com a entonação.

Para a análise dos dados, é importante esclarecer que não se tem como pressuposto, aqui, que a pontuação serve para marcar a respiração durante a leitura, mas sim que ela tem uma função sintática, prosódica e discursiva. Essas dependem da intenção comunicativa do falante e da estrutura selecionada por ele para a sua comunicação, o que faz com que a pausa da fala não seja apenas para o falante respirar, mas para realizar atos de fala e para marcar alguns limites sintáticos fundamentais para o sucesso da comunicação.

O gráfico a seguir apresenta o número de desvios dos microcritérios estabelecidos para esta análise, que podem ser a presença de vírgula em local considerado pelas Gramáticas 
Tradicionais como impróprio, ou a ausência desse sinal gráfico em posições que dele prescindem. Os resultados serão apresentados com base em duas características: ausência do uso da vírgula e do ponto final e uso inadequado da vírgula. Além disso, serão apresentadas comparações entre os eventos linguísticos analisados nos dados e suas ocorrências no texto oral. Assim será possível buscar, na fala, motivações que justifiquem os desvios feitos pelos alunos em relação à norma padrão, no que tange à pontuação.

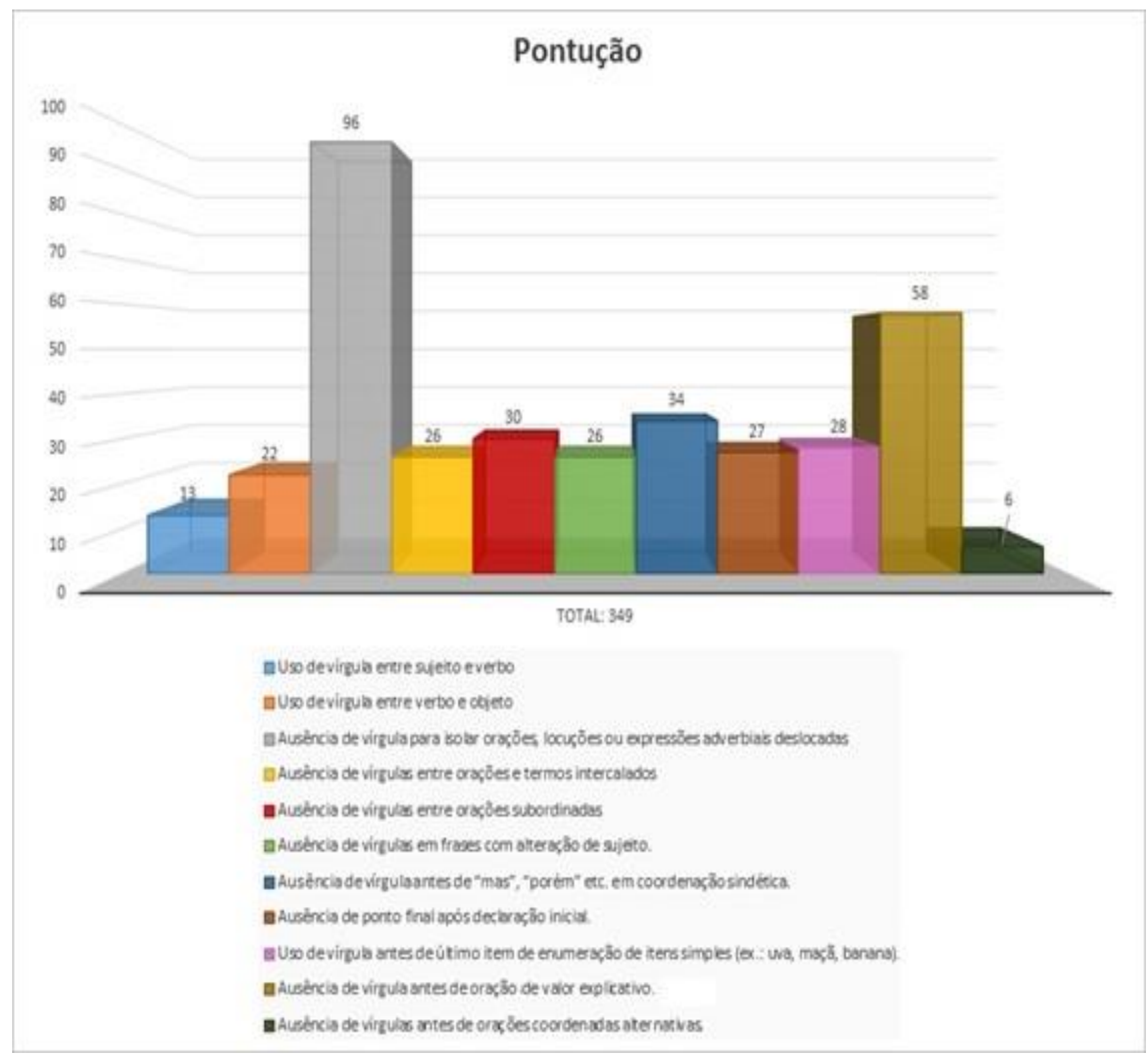

Gráfico 11 - Pontuação

O gráfico apresenta onze microcritérios de análise, definidos e analisados, conforme apresentado no capítulo anterior. Durante o processo de análise e organização dos dados, 
percebeu-se que os microcritérios 5d e 5e (ausência de vírgulas entre orações e termos intercalados e ausência de vírgulas antes de orações subordinadas) já estavam sendo utilizados nas análises dos microcritérios 5 c e $5 \mathrm{j}$ (ausência de vírgula para isolar orações, locuções ou expressões adverbiais deslocadas e ausência de vírgula antes de oração de valor explicativo). Em razão disso, foram mantidos seus resultados no gráfico, mas eles não serão analisados individualmente, pois, no fim das contas, seria apenas um recorte do que já teria sido apresentado.

\section{Ausência de vírgulas para isolar orações, locuções ou expressões adverbiais deslocadas.}

O desvio mais produtivo entre os microcritérios relacionados à pontuação foi a ausência de vírgulas para isolar as orações, locuções ou expressões adverbiais deslocadas. Sobre isso, as Gramáticas Tradicionais investigadas postulam, em linhas gerais, que advérbios, locuções adverbiais e orações adverbiais, principalmente quando deslocados de seu lugar original (o último termo da oração), devem ser isolados por vírgula, geralmente, sobretudo para efeito de ênfase.

O material do CEBRASPE, utilizado nesta pesquisa, pontua que os adjuntos adverbiais longos, com mais de três termos, quando deslocados para início da oração, devem vir isolados por vírgula. Abreu (2003) aponta que há quebra entonacional e consequente uso de vírgula, quando os adjuntos adverbiais se dão sob forma de orações; já os demais casos de adjuntos adverbiais podem ocasionar quebra entonacional ou não, a depender da intenção do falante, sendo, portanto, opcional o uso da vírgula.

O fato de o uso da vírgula ser opcional na maioria dos casos em que se usa o advérbio pode justificar o alto índice de ausência de vírgulas nos dados, já que 93 das 150 redações analisadas apresentaram esse desvio. Pode-se entender que os alunos não viram a necessidade de, na escrita, enfatizar a informação apresentada pela estrutura em foco.

5cPT012 - Em minha opinião a leitura é uma das maiores importâncias do ser humano.

5cPT019 - Porém, ao ler um livro você enche sua cabeça de gramática e informações muito mais confiáveis. 
5cPT135 - Hoje em dia o povo indígena está sendo maltratado por várias pessoas, espêcialmente por pessoas que nem moram no Brasil.

5cPT137 - Cada vez mais os índios vivem mais nas aldeias que viviam.

5cPT139 - Depois de um tempo a cultura deles irá esgotar, não vao mais viver em ocas vão comessar a viver em casas modernas.

Os dados indicam que há preferência pelo deslocamento do adjunto adverbial e de orações adverbiais, entre os alunos do sexto ano, para o início da frase. A expectativa dessa análise era de que os alunos fossem marcar, com maior frequência, os adverbiais com vírgula, tendo em vista que, na fala, haveria uma pausa depois da estrutura em foco. Contudo, os dados contrariaram a hipótese inicial. Assim, haveria uma baixa influência da entonação na pontuação de construções que usem as estruturas analisadas no microcritério em baila. Apesar disso, há, também, o uso esperado da vírgula no caso em questão, como se pode ver no exemplo a seguir.

5cPT002 - Antes dos aparelhos eletrônicos virarem fama, o hábito de ler era grande. Agora, as pessoas acham que vão aprender mais com joguinhos eletrônicos e elas estão parando de ler.

Nota-se que o autor do trecho marcou adjuntos adverbiais simples e sob forma de oração, ambos deslocados para o início da frase. Nesse caso, pode-se falar de influência da entonação na pontuação. Como parte do processo de análise deste estudo, buscou-se averiguar se, na fala, de fato, a quebra prosódica acontece quando há estruturas com adverbiais, a fim de verificar se a percepção da maioria dos alunos está pertinente aos fatos da fala. Para isso, selecionou-se uma edição do quadro "Caderninho da Bel ${ }^{49}$ ", da rádio CBN que foi submetido à analise acústica no programa PRAAT, a fim de se identificar se há quebra entonacional quando o adverbial é deslocado de sua posição prototípica. Os dados relativos à oralidade, sempre serão, aqui, apresentados de acordo com a transcrição grafemática, com a pontuação indicada pela norma padrão, independentemente de sua correspondência com as marcas entonacionais da sentença. Além disso, como o foco da análise não tem relação com os segmentos, não haverá transcrição dos dados para o alfabeto fonético.

\footnotetext{
${ }^{49}$ Disponível em: https://www.youtube.com/watch?v=9jcF969SU3s . Acesso e download em 11 de setembro de 2015.
} 


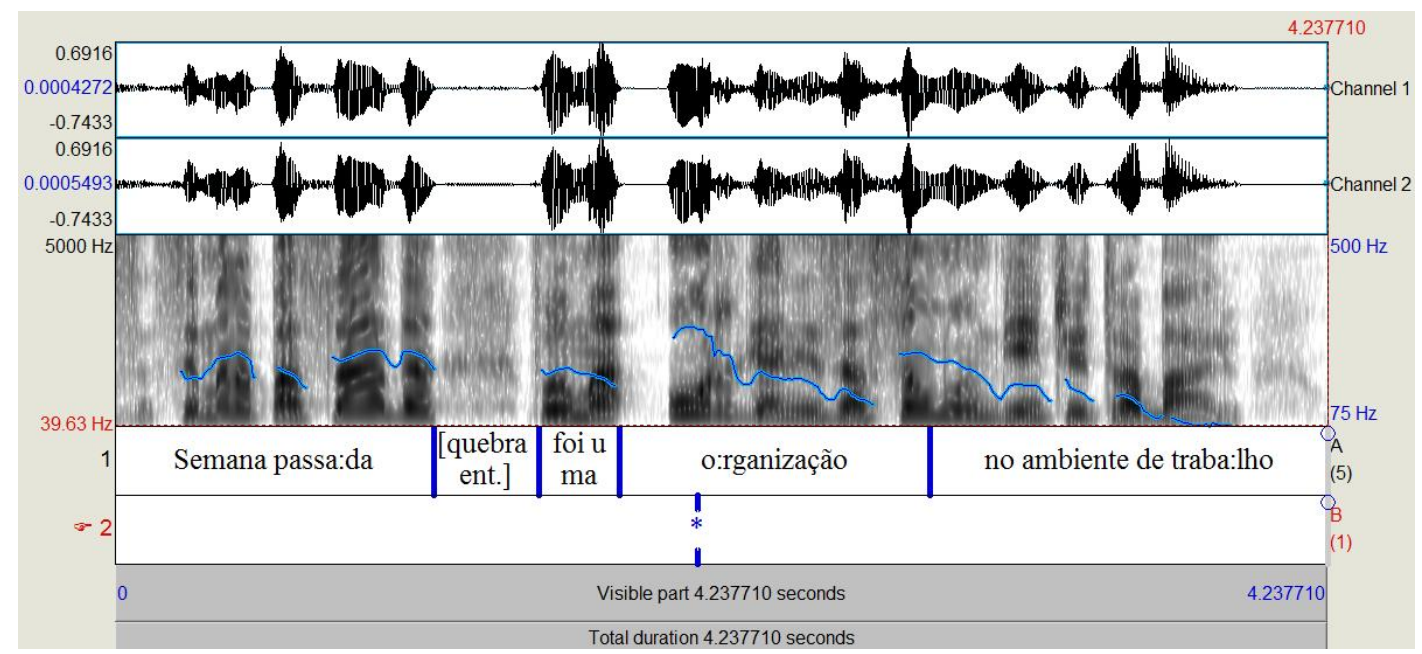

Figura 35 - PRAAT 1

A figura PRAAT 1 analisa o trecho " $\mathrm{Na}$ semana passada, foi uma organização no ambiente de trabalho". Nela é possível comprovar que, quando o adjunto adverbial está em sua posição prototípica (fim da oração, como já mencionado) não há quebra entonacional, porém, quando o adverbial é deslocado para o início da frase, há quebra bem visível na análise acústica. $\mathrm{O}$ adjunto adverbial deslocado "Na semana passada" é considerado longo, portanto deve vir isolado por vírgula na escrita. Nesse caso, observa-se que, se os alunos usassem sua percepção de falante nativo para pontuar o texto escrito, mais acertos eles teriam sobre o uso da vírgula no caso em foco.

Os dados escritos também apresentam a inserção de advérbios antes de verbos, não marcados pelo uso da vírgula, assim como orações adverbiais, ambos marcados na fala pela quebra entonacional. $\mathrm{O}$ exemplo a seguir apresenta uma sequência de adverbiais, em que, pelo menos, a oração adverbial condicional deveria ter a quebra entonacional que a acompanha na fala, marcada pela vírgula na escrita. Além disso, relembrando-se os ensinamentos de Abreu (2003), quando há mais de um adverbial juntos, ainda mais estando fora da posição original, pelo menos uma vírgula deverá ser usada no texto escrito, o que não tem sido feito pelos alunos de sexto ano.

5cPT003 - A leitura influencia a inteligência, e se você ler bastante desde pequeno eventualmente será mais inteligente.

Para comparar o exemplo acima com o texto oral, será analisado o trecho "E... a gente comentou, recentemente, no "Desafio do Caderninho", que a limpeza ou a organização do seu ambiente acabam influenciando na organização dos seus pensamentos também". As estruturas 
a serem analisadas estão destacadas, e, como se pode observar, é o caso de ocorrer dois adjuntos adverbiais, consecutivos. Para gerar uma análise mais nítida da fala, o trecho será analisado em segmentos. O primeiro segmento, com foco nos advérbios, será: "E... a gente comentou, recentemente, no "Desafio do Caderninho", que a limpeza ou organização".

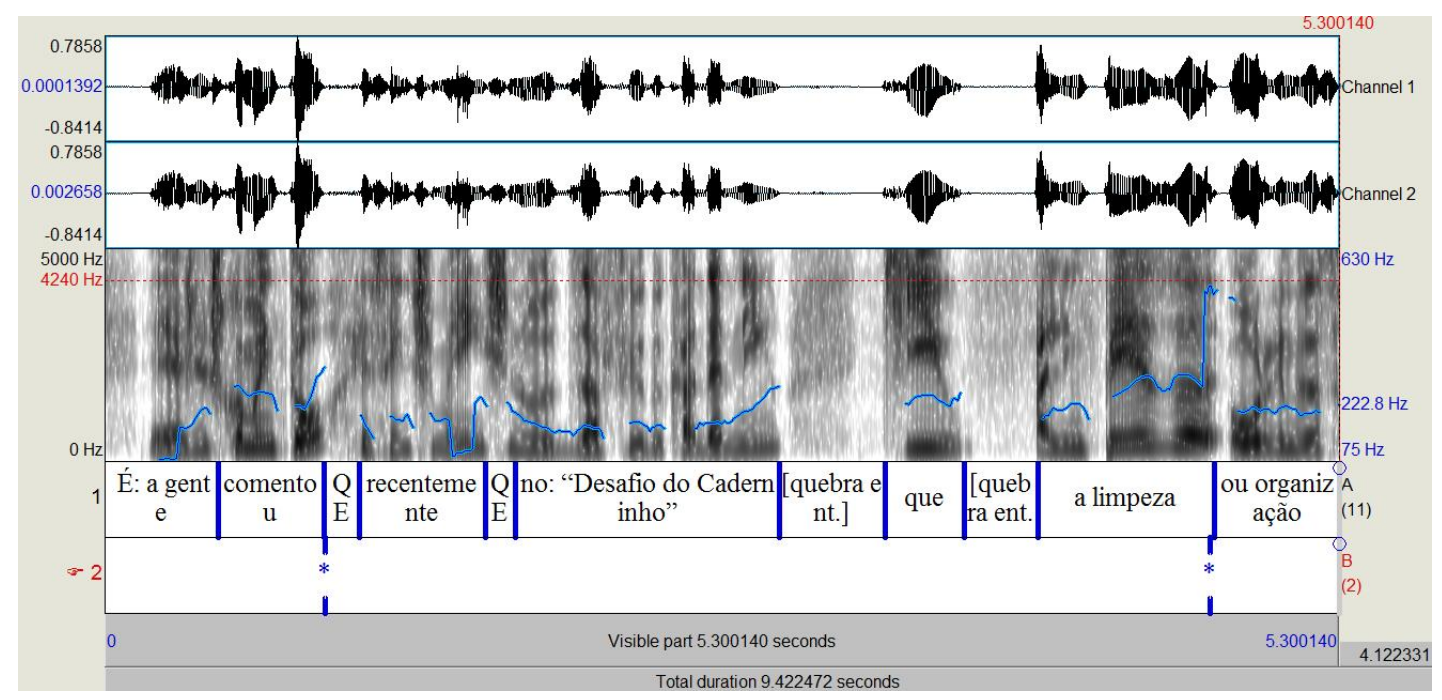

Figura $36-$ PRAAT 2

A figura PRAAT 2 revela que há correspondência entre quebra entonacional (QE) e pontuação, isolando os termos adverbiais. Nota-se duas naturezas de QE, uma, curta e com indícios acústicos de formação e finalização de sílaba, e outra, longa, com marcação de respiração. Para isolar "recentemente", é visível a quebra da linha que marca o pitch (linha azul), o que indica uma breve quebra entonacional. Porém, ao se analisar os formantes, nota-se que as quebras correspondem ao início da formação do som da letra 'r', e com o final da sílaba 'ti', como se pode observar a seguir. Na figura, podem-se notar os formantes (em vermelho), os quais podem ser definidos como picos de energia em uma região do espectro sonoro, em outras palavras, indica a presença de um som. Além disso, a quebra entonacional entre "que" e "a limpeza" parece ser de motivação discursiva, para enfatizar o segundo termo, e não tem justificativa sintática. 


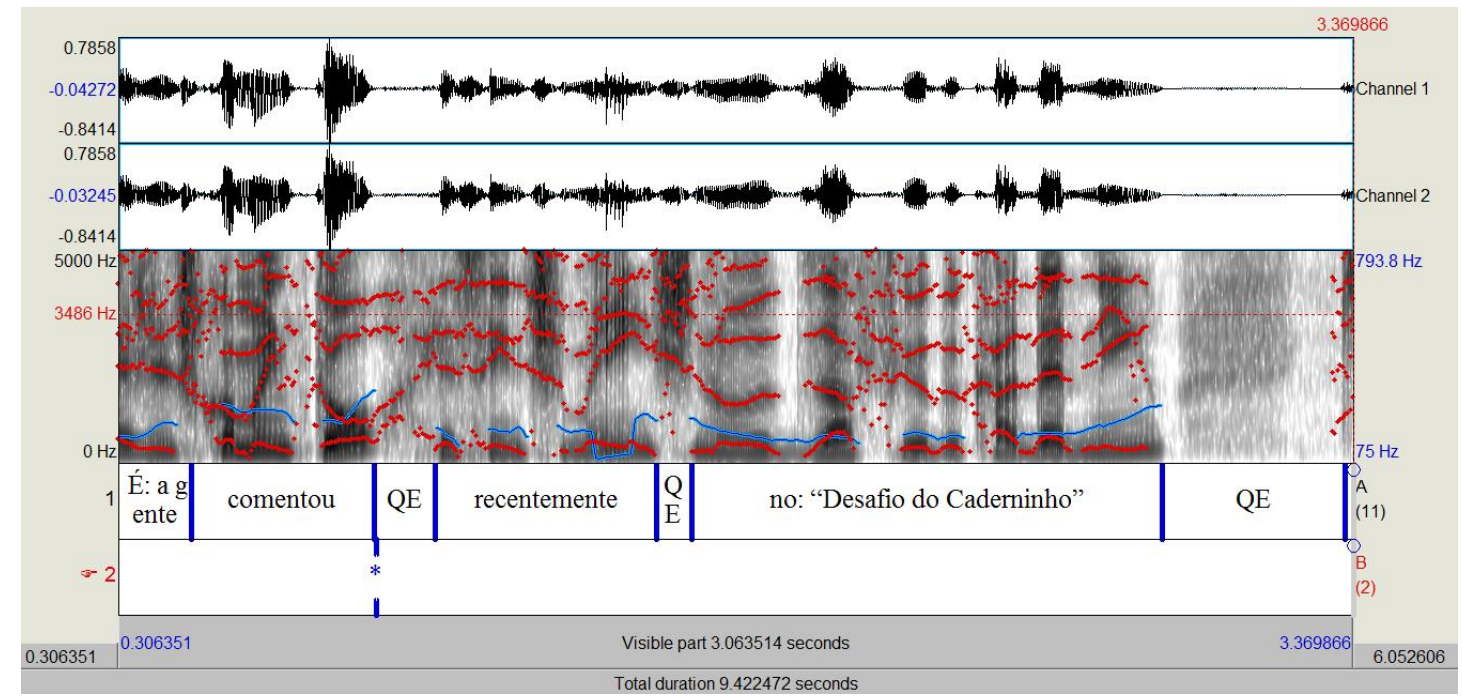

Figura 37 - PRAAT 3

A figura PRAAT 3 deixa evidente que, na realidade, não há quebra entonacional para isolar "recentemente", o que justifica o uso opcional da vírgula, como recurso para a ênfase no discurso. Isso já não se observa em "no Desafio do Caderninho", que tem seu final marcado com real QE, explicitada pela ausência de sinais indicadores de formantes, pois não há ressonância de som ao final desse termo adverbial.

Retomando a análise dos dados escritos, nota-se que os alunos relacionam, em alguma medida, a percepção sonora com o uso da pontuação. Isso justifica a ausência de pontuação em alguns casos, como, no exemplo 5cPT003. Nele o autor não isolou o adverbio "eventualmente", o que indica a falta de intencionalidade discursiva em destacar o termo, a não obrigatoriedade sintática de uso da vírgula e a não percepção de QE na relação entre fala e escrita. Esse uso do adverbial, então, está alinhado ao uso ideal da língua portuguesa.

Ainda sobre o exemplo 5cPT003, é interessante observar que o autor não isola por vírgulas a o termo adverbial oracional "e se você ler bastante desde pequeno", que deveria ser obrigatoriamente isolado por vírgulas. Esse aluno seguiu na contramão dos demais exemplos apresentados anteriormente, em que os alunos percebem a necessidade de se usar a vírgula no uso dessa estrutura, como se pode confirmar nos excertos já apresentados e analisados, como em 5cPT002, “Antes dos aparelhos eletrônicos virarem fama, o hábito de ler era grande”. Para se comparar a estrutura escrita com o texto oral, selecionou-se o trecho "E se for algumas daquelas coisas que não têm solução, tenta finalizar de alguma forma esse assunto também", do áudio em análise. 


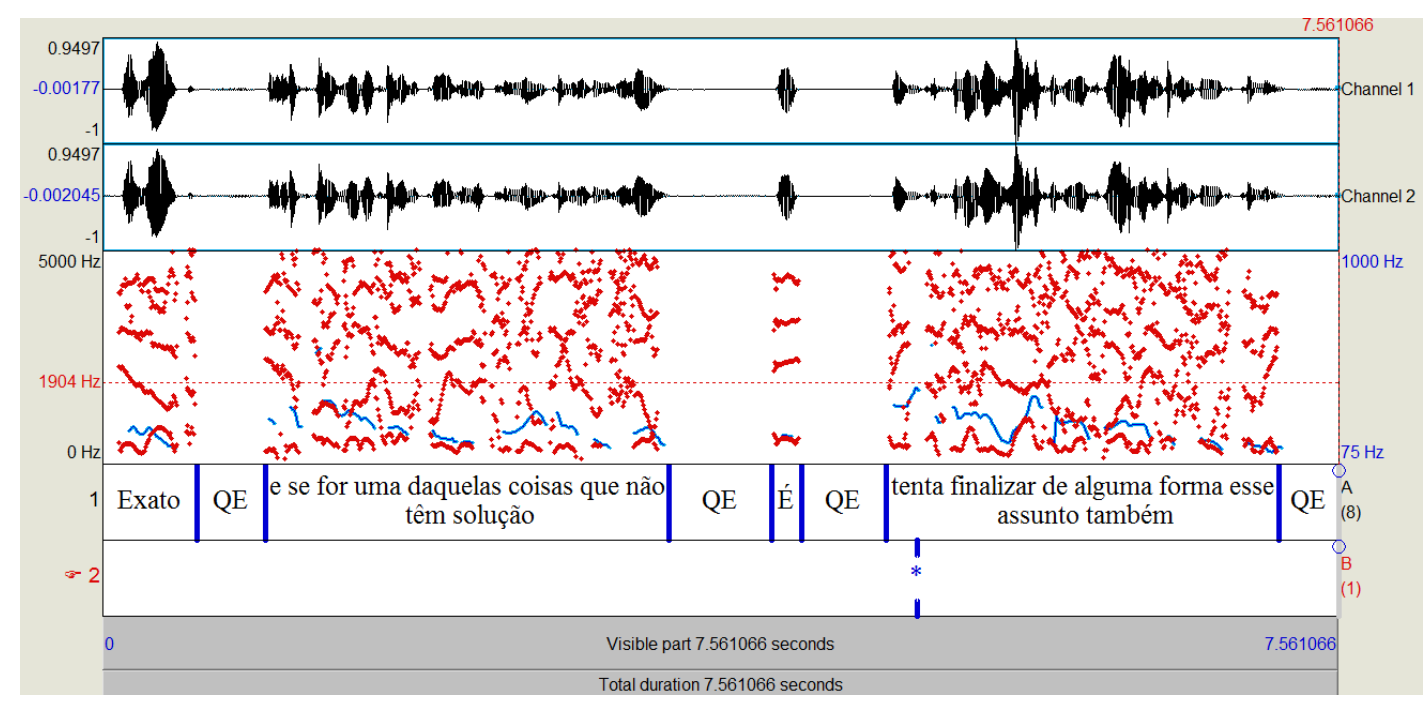

Figura 38 - PRAAT 4

Nessa representação, optou-se por mostrar as formantes, em vermelho e o pitch em azul. Não foi preciso recorrer ao espectrograma para se ter claro que o termo adverbial oracional "se for uma daquelas coisas que não têm solução" vem isolado por QEs, visíveis também pela ausência de vibrações marcadas em Channel 1 e Channel 2. Dessa forma, o texto oral confirma a necessidade de se isolar por vírgulas a estrutura em foco. Essa análise sugere, então, que o autor do exemplo 5cPT003 não percebeu a QE, portanto não a transpôs para o texto escrito, ou não relacionou entonação com a pontuação.

\section{Ausência de vírgula antes de oração com valor explicativo.}

As orações que apresentam, no discurso, um valor de explicação, são, em geral, antecedidas pelo uso da vírgula, segundo prescrevem gramáticos como Cunha \& Cintra. É o caso dos apostos explicativos e das orações adjetivas explicativas. Em termos entonacionais, Abreu (2003) defende que há QE antes de expressões explicativas e em apostos. Assim, esperava-se que os termos explicativos, nos dados, fossem precedidos pela vírgula.

Porém, esse microcritério foi o segundo mais produtivo em número de desvios entre os textos escritos, presente em 58 textos, o que leva a considerar que os alunos não percebem a necessidade sintática da pontuação, nem a variação de sentido que a ausência da vírgula pode causar, tampouco a quebra entonacional que deve anteceder, na fala, a estrutura explicativa. Vale considerar que o uso de estruturas explicativas, sobretudo no nível oracional, é um recurso 
mais complexo da língua, considerando a faixa etária dos alunos, porém está presente na maioria dos textos, até pela natureza argumentativa que esses apresentam. Assim, são comuns trechos como os que seguem.

5jPT129 - Eles são importantes pois fazem parte dos brasileiros.

5jPT130 - Por isso que os índios devem receber a atenção dos governantes e da sociedade porque eles também são pessoas normais.

5jPT133 - Não devemos descriminar ninguém porque existe uma regra de ouro que vale para qualquer um(...).

5jPT134 - Eles (os índios) não são animais eles tem uma cultura e família como todos nós e querem distruir as terras deles e isso não é justo porque os índios chegaram lá antes então o espaço é deles.

Observa-se que os exemplos indicam a ausência de vírgula em um caso específico, apresentado por Azeredo (2008: 522) condição obrigatória para o uso da vírgula: orações coordenadas, que não sejam aditivas. Os dados indicam que os alunos não percebem, estrutural e prosodicamente, a necessidade de se usar a vírgula antes de termos como "pois" em situações como as apresentadas.

A análise acústica do trecho que é a continuação do excerto analisado anteriormente, representado pela figura PRAAT 4, mostra a quebra entonacional entre uma oração coordenada e outra, antes ao termo "porque". Assim, é necessário representar essa quebra na escrita, e, como ensinou Azeredo (2008), usar a vírgula antes da conjunção em orações coordenadas, com exceção da aditiva.

A imagem seguinte representa o trecho "tenta finalizar de alguma forma esse assunto também, porque esses pensamentos ficam voltando e algumas vezes são pensamentos negativos". É visível o silêncio entre "também” e "porque", com atenção para os formantes, que não ressonam som nesse intervalo, o que confirma a quebra entonacional. No mesmo exemplo, pode-se ver que, entre coordenadas aditivas, com o uso do "e", não acontece a QE quando o sujeito é o mesmo, como prova "esses pensamentos ficam voltando e $\underline{\text { algumas vezes }}$ são pensamentos negativos”. Na figura PRAAT 5, não há qualquer indicação de pausa entre as orações aditivas, o que justifica essa ser a exceção marcada por Azeredo em sua gramática. 


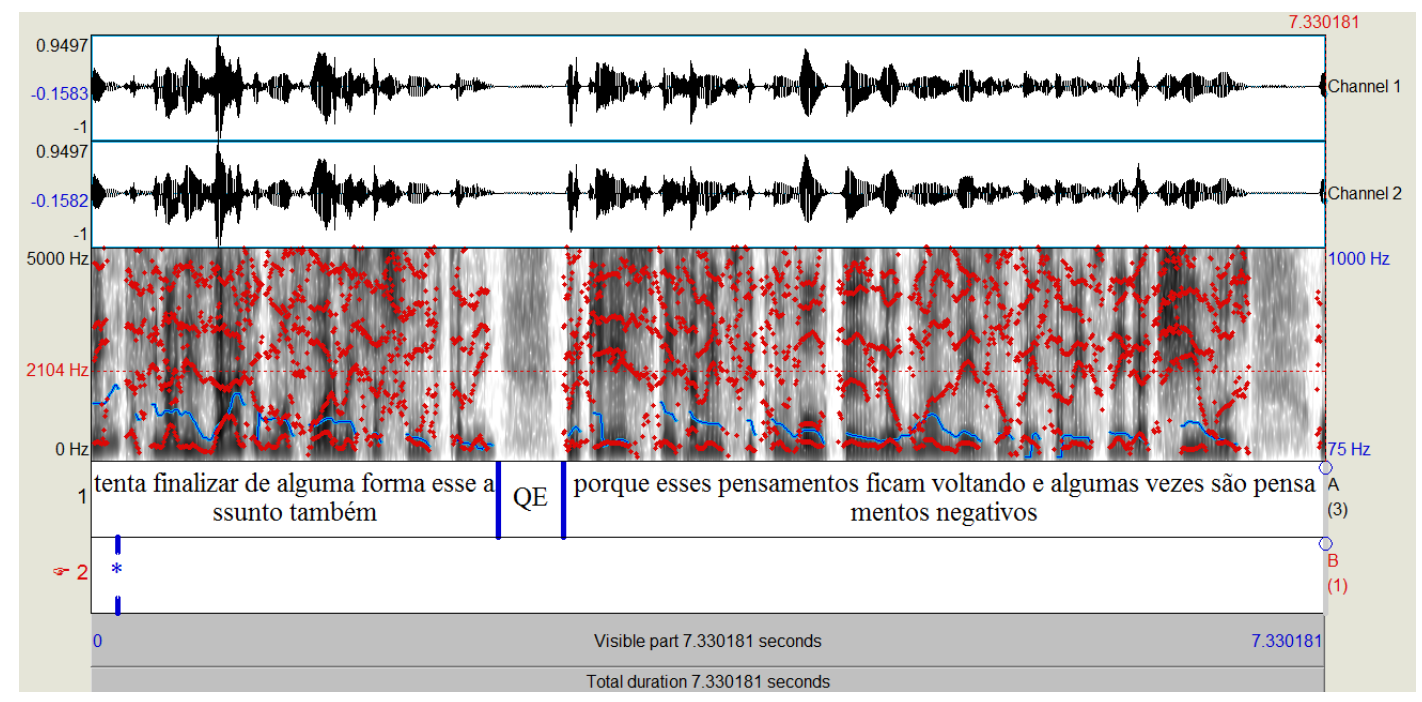

Figura 39 - PRAAT 5

Mais uma vez, os dados confirmam o que os questionários indicaram: os alunos têm dificuldade em relacionar fala e escrita, tanto no nível segmental, quanto no suprassegmental. Esperava-se que a influência da entonação interferisse na escrita dos alunos nos casos de orações de valor explicativo, pois a pausa que a antecede já havia sido considerada no momento da elaboração dos microcritérios de análise. Contudo, era preciso comprovar a hipótese na análise acústica e confrontar seu resultado com o texto escrito. Assim, a alta frequência da ausência de vírgula nessa posição é mais uma quebra de expectativa proporcionada pelas produções de textos dos alunos.

Além da coordenação, a análise acústica também confirma a necessidade do uso de vírgula para marcar a oração adjetiva explicativa. A representação a seguir mostra a análise do trecho "E eu queria falar um pouquinho de uma limpeza muito importante que às vezes a gente deixa de lado, que é a limpeza da sua mente". 


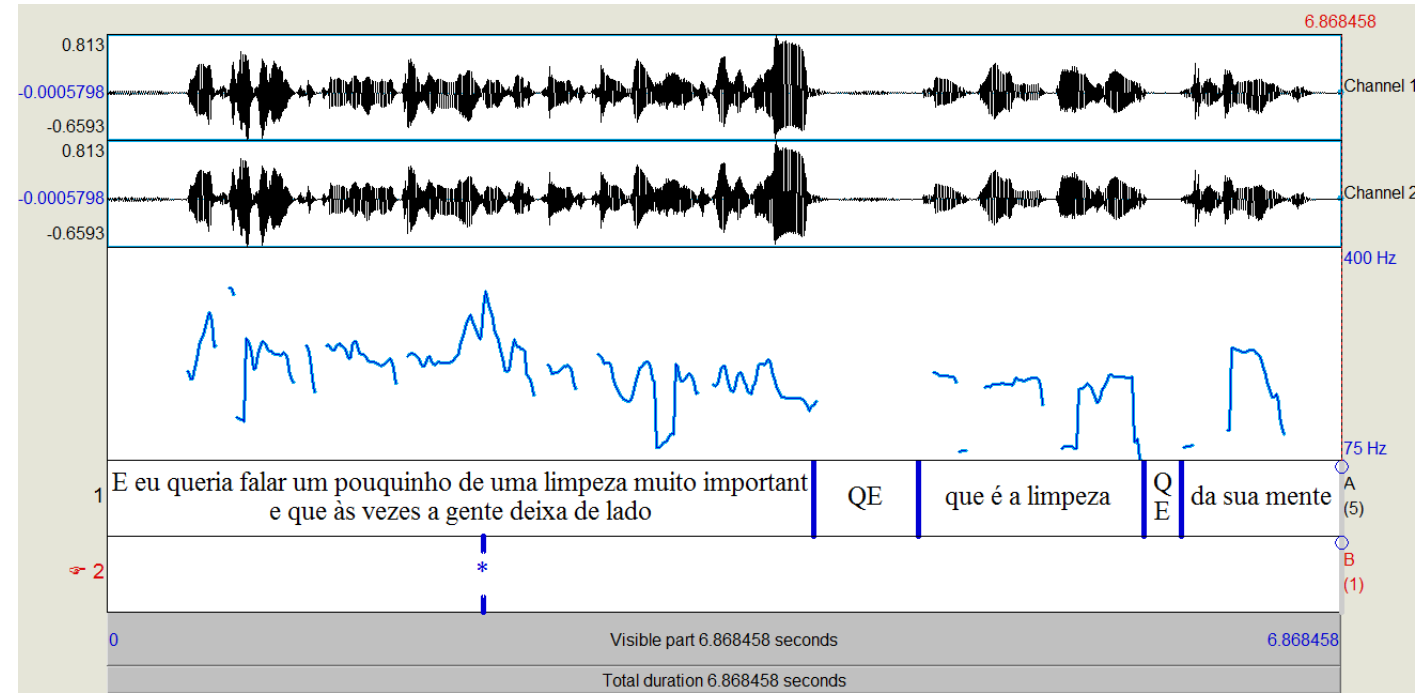

Figura 40 - PRAAT 6

A análise do pitch mostra que há, de fato, uma necessidade também entonacional de se usar a vírgula antes da oração adjetiva de valor explicativo. A quebra entonacional marcada antes do pronome relativo "que" é de aproximadamente 0.5 segundos, apenas 0.3 segundos mais curta que o tempo de produção do termo "da sua mente", formado por três palavras morfológicas. Isso indica ser uma pausa considerável e perceptível, que motiva e justifica a regra ensinada aos alunos de que as orações adjetivas explicativas são marcadas pelo uso da vírgula.

\section{Ausência de vírgula antes de "mas", "porém” etc. em coordenação sindética}

Em terceiro lugar em número de desvios, presente em 34 redações, a ausência de vírgula antes de termos adversativos, como "mas" e "porém", é mais uma dificuldade no uso da pontuação de textos escritos. Bechara (2009) ensina que se deve usar a vírgula para separar conjunções e advérbios adversativos, sobretudo quando pospostos. A posposição é um recurso que prescinde do uso da vírgula, por sua própria natureza de deslocamento de estrutura, portanto não é fator relevante para esta pesquisa. Além disso, esse movimento denota refinamento no uso da língua escrita que os alunos do sexto ano ainda não detêm.

Nos dados escritos, o exemplo a seguir representa o uso da estrutura em questão, com destaque para o fato de o aluno não usar a vírgula nessa sentença. Isso demonstra a pouca 
familiaridade, também esperada e comum aos alunos do sexto ano, com os recursos proporcionados pela pontuação.

5gPT139 - Então o governo devia fazer algo sobre isso mas não o governo quase não se preocupa com os índios fazendo assim que a cultura indígena acabe.

É interessante observar que no texto de língua oral, com o qual as análises acústicas estão sendo realizadas, não há a ocorrência da estrutura em foco, como pode ser confirmado em sua transcrição, no capítulo anterior. Em virtude disso, o único critério de avaliação para a presença ou ausência de quebra entonacional antes de adversativas é o conhecimento de falante nativa da língua portuguesa da pesquisadora, que acredita haver quebra entonacional para justificar a instrução de Bechara (2009). Porém, vale ressaltar, que Abreu (2003) não menciona essa ocorrência entre as situações em que há, obrigatoriamente, a quebra entonacional.

\section{Ausência de vírgulas em frases com alteração de sujeito - aditivas e alternativas}

Em 26 textos, foi percebida a ausência de vírgula para indicar orações coordenadas com sujeitos diferentes, que devem ser marcadas, na escrita, por essa pontuação, principalmente quando se usa "e" como conjunção. O exemplo a seguir mostra uma frase em que há relação de coordenação introduzida por "e" entre as orações "As culturas deles são diferentes das nossas" e "eu acho isso muito legal”. Na primeira oração, o sujeito é o termo "As culturas deles", já na segunda oração, o sujeito é "eu”, assim está claro que se trata de orações coordenadas, ligadas por "e", com sujeitos diferentes.

5fPT135 - As culturas deles são diferentes das nossas e eu acho isso muito legal porque é bom ser diferente as veses.

Diferentemente do que ensinam as gramáticas tradicionais, o aluno não utilizou vírgula antes da conjunção aditiva. Isso pode ser justificado por essa possibilidade de a pontuação ser a exceção à regra de que não se pode usar vírgula antes de "e". A obrigatoriedade da vírgula 
nessa posição é justificada pela entonação, já que a análise a seguir comprova haver uma quebra entonacional exatamente antes do "e".

O trecho dos dados de fala analisado, e representado a seguir, apresenta a necessidade de uso da vírgula, quando representado no texto escrito, exatamente nas posições indicadas pela gramática tradicional. O primeiro caso de quebra entonacional diz respeito à introdução do tema a ser tratado, um recurso catafórico evidenciado pelo termo "seguinte". Nesse caso, os dois pontos poderiam ser um recurso usado para representar a quebra entonacional marcada na oralidade, na posição em análise.

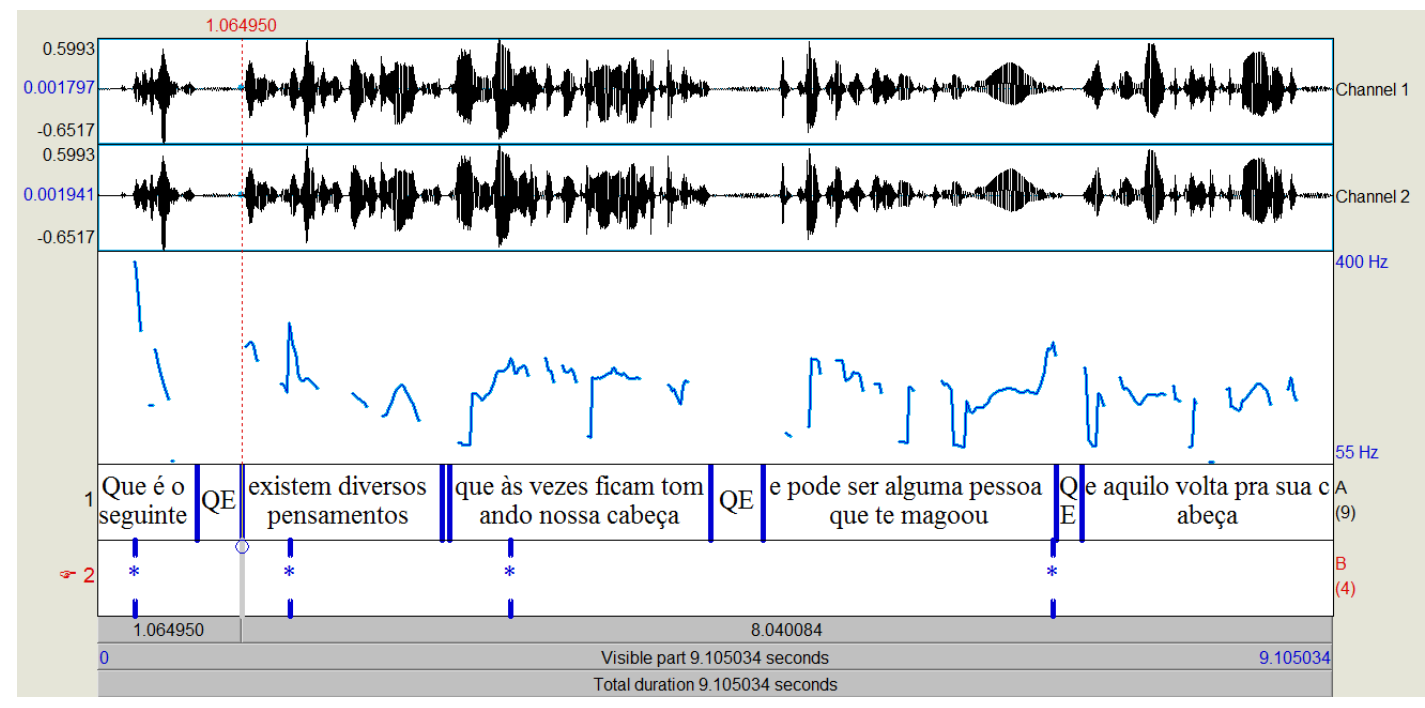

Figura $41-$ PRAAT 7

Como se pode observar, há no trecho "que é o seguinte: existem diversos pensamentos que, às vezes, ficam tomando nossa cabeça, e pode ser alguma pessoa que te magoou, e aquilo volta pra sua cabeça", quatro quebras entonacionais, sendo a segunda bem curta. Nessa construção, há três estruturas coordenadas, cada uma com um sujeito próprio, e essa alternância é marcada pela quebra entonacional, como já mencionado, logo esse é mais um caso em que a entonação confirma a necessidade de, na escrita, se usar a vírgula.

Outro tipo de coordenação que tem a mesma característica da aditiva, de possibilitar sujeitos diferentes em uma mesma frase, é a coordenada alternativa. Nos dados escritos, seis redações apresentaram ausência de vírgula antes desse tipo de oração, número baixo se comparado às aditivas. Nota-se, então, que é mais fácil para o aluno de sexto ano perceber a quebra entonacional em mudanças de sujeito nas orações alternativas que nas aditivas.

Retomando o exemplo 5fPT135, nota-se, então, que seu autor não percebeu a característica prosódica da estrutura que utilizou, isto é, não identificou a quebra entonacional 
entre as orações. Se o fez, não se sentiu seguro para usar a pontuação em questão na estrutura criada. É interessante observar que, nos questionários, os alunos responderam que a vírgula tem a função de indicar pausa, mas, em suas produções, eles não percebem a necessidade desse recurso.

Vale considerar que o Manual do CEBRASPE não recomenda, nas correções de seus certames, que seja penalizada a ausência de vírgula no caso enfocado. Para ele, exceto se a estrutura possibilitar ambiguidade sintática ou semântica, o não uso de vírgulas em orações coordenadas com sujeitos diferentes não deve ser visto como um erro.

\section{Ausência de ponto final após declaração inicial.}

Como último microcritério relativo à ausência de pontuação, tem-se a troca do uso do ponto final pelo da vírgula, em final de declaração inicial. A inserção desse microcritério deveuse à prescrição encontrada no Manual CEBRASPE, em que se considera erro a substituição apresentada.

É possível relacionar a estrutura desejada com a frase núcleo, ou tópico frasal, do parágrafo padrão, já que essa delimita o assunto que deverá ser abordado no parágrafo a ser desenvolvido, e, em geral, aparece como a primeira frase. A declaração inicial, que deve ser marcada pelo ponto final (e não ser completada pelo uso da vírgula), conserva características semelhantes ao tópico frasal, a começar pelo fato de ser o primeiro elemento da estrutura paragrafal.

Nos dados, 27 redações apresentaram a substituição em foco. Não é um número alto de erros, o que leva a concluir que, nesse aspecto, os alunos percebem a quebra entonacional existente, e a relacionam com a necessidade de encerrar a frase. O exemplo a seguir ilustra essa ocorrência.

5hPT141 - Eles (os índios) merecem a atenção da sociedade e do governo, isso porque os índios estão morrendo de doenças, porque não têm medicamentos para curar as doenças como gripe e sarampo. 
O autor do exemplo inicia seu parágrafo com a afirmativa de que os índios "merecem a atenção da sociedade e do governo". Esse era o assunto a ser desenvolvido nessa parte do texto, e, por isso, exercia a função de tópico frasal. Sendo assim, essa é considerada uma frase declarativa, que requer o ponto final ao seu término, e não uma vírgula como foi usada no texto do aluno.

Para confirmar a necessidade, de se finalizar a declaração inicial com um ponto final, e não como uma vírgula, na escrita, será analisado o trecho da oralidade em que a colunista Bel Pesci introduz o tema sobre o qual ela irá tratar durante o programa de onze de setembro de 2015. Nesse ponto, o apresentador do programa diz: "Semana passada, foi uma organização no ambiente de trabalho. Hoje você está propondo limpeza onde?”. Em seguida, Bel Pesci diz o trecho que será analisado acusticamente: "Uma limpeza mental. Eu vou explicar isso um pouquinho melhor".

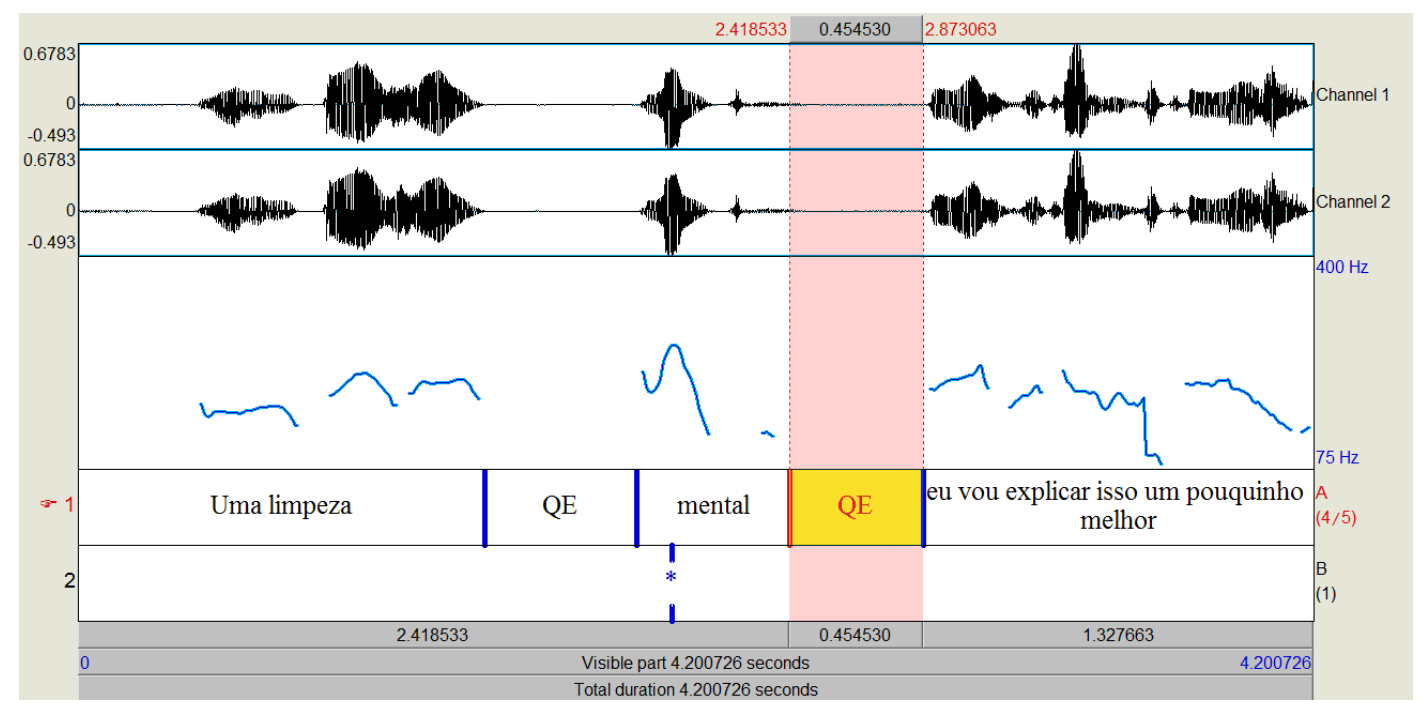

Figura $42-$ PRAAT 8

Como se pode observar, a figura PRAAT 7 apresenta, no final da declaração inicial, uma quebra entonacional. Essa quebra pode ser representada, na escrita, tanto pela vírgula quanto pelo ponto final. Chega-se a essa conclusão ao se analisar o tempo da pausa no final da declaração inicia, que é de 0,45 segundos. Há ainda, no trecho, outra quebra entonacional, realizada sem função gramatical, mas com a função discursiva de enfatizar o termo que sucede essa pausa. No texto escrito, essa ênfase poderia ser marcada por vírgulas duplas, de forma que o termo "mental" ficasse entre vírgulas. Nesse caso, há a possibilidade de se gerar um problema estrutural, de forma que a melhor opção é não transpor para a escrita essa marca enfática da 
fala, pois estaria se separando termos que precisam permanecer sintaticamente juntos "limpeza mental".

É interessante, então, comparar o tempo de duração das duas pausas para se observar a possibilidade de haver uma duração maior em pontos finais que em vírgulas, como apregoam alguns professores de língua portuguesa em suas aulas, e confirmam as respostas dos questionários dos alunos, apresentados anteriormente. $\mathrm{O}$ primeiro silêncio, entre os termos "limpeza" e "mental", tem duração de 0.51 segundos, já o segundo, que marcaria o ponto final, dura 0,45 segundos. Com base nisso, o tamanho da pausa não justifica a diferença de uso da vírgula e do ponto final. Essa distinção, na verdade será feita pela curva entonacional (picth).

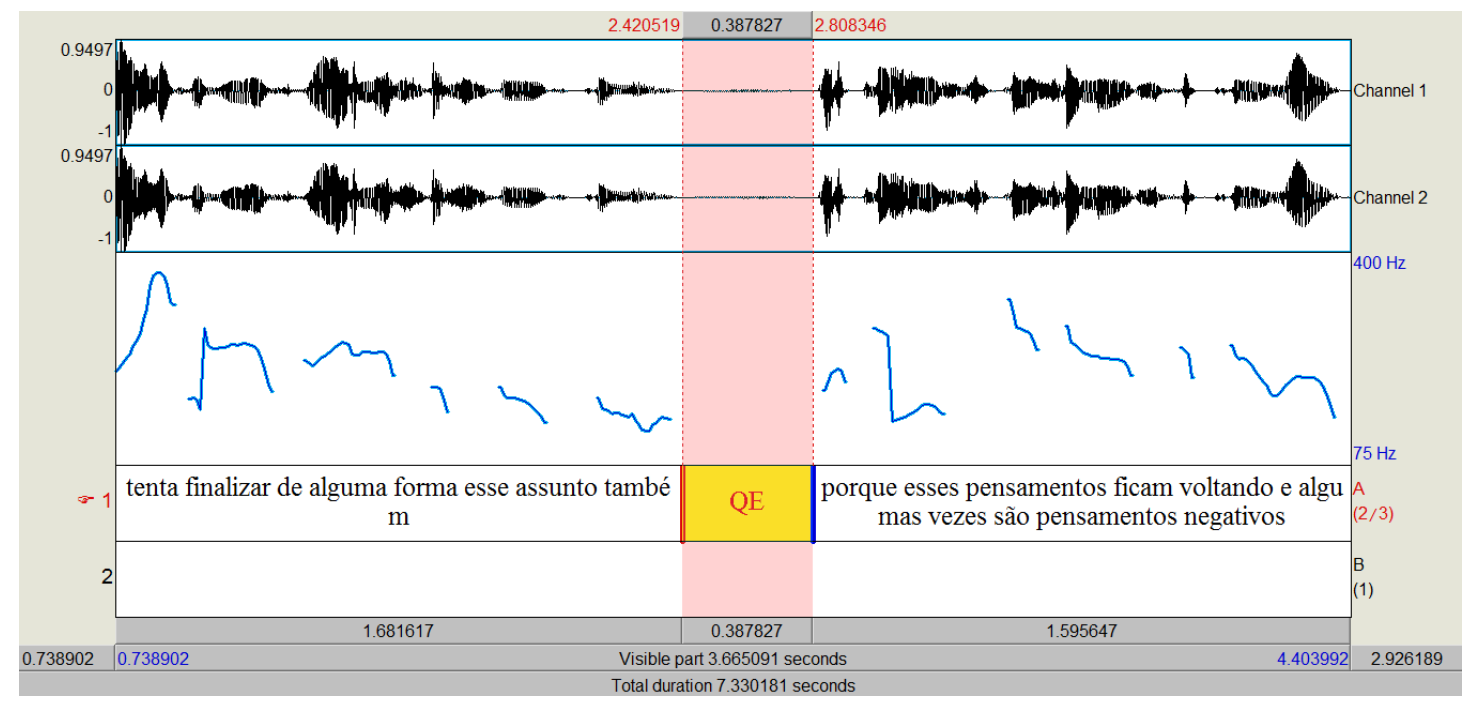

Figura $43-$ PRAAT 9

Quando se trata de uso da vírgula, como pode ser observado nas figuras PRAAT 7 e PRAAT 9, a curva vem em sentido ascendente, subindo, acontece a pausa, e o movimento de subida da curva continua. Quando se tem uma posição em que se deve usar o ponto final, a curva vem em um movimento descendente, acontece a pausa, e o próximo trecho de fala se inicia já com a curva mais alta, do que antes da pausa, e estável, seguindo em um leve movimento ascendente, como na figura PRAAT 8.

Em uma análise mais precisa, a curva entonacional (pitch) representada na figura PRAAT 8, inicia o movimento de descida a partir de 264,2 hertz (Hz) e para no momento antecedente ao silêncio em $126 \mathrm{~Hz}$. Após a pausa, a fala é iniciada com uma frequência de 196,8 $\mathrm{Hz}$, com ascendência para $233,2 \mathrm{~Hz}$, aproximadamente 0,2 segundos depois, o que indica certa estabilidade da altura da curva. Dessa forma, apenas em casos nos quais a curva entonacional mantenha movimento similar a esse é que se usará o ponto final. Vale destacar que perceber 
essas variações na fala é muito complexo, o que justifica o uso de vírgula no lugar do ponto final após declaração inicial.

\section{Uso de vírgula antes de último item de enumeração de itens simples e o uso de reticências.}

$\mathrm{Na}$ fala, a enumeração de itens tem um ritmo próprio, que reflete na escrita dos alunos de sexto ano de duas formas distintas e complementares: uso de vírgula antes do último termo da enumeração e uso de reticências para encerrar a sequência. Ambos os usos estão fora do padrão de língua que deve ser empregado para a construção de textos argumentativos, sobretudo os de circulação acadêmica, sendo os dois recursos aceitáveis em narrativas.

Em 28 redações, enumerações foram feitas com a vírgula antecedendo o último item, acompanhada ou não da conjunção "e". O uso de reticências não foi um microcritério estabelecido para análise, porém seu alto índice de ocorrência chamou a atenção, e por isso também será comentado.

Em geral, as duas pontuações acontecem juntas, quando o aluno usa a vírgula antes do último item, usa também as reticências para atribuir à informação um sentido de continuidade ou de suspensão da ideia, não de finalização. É comum, ainda, a ocorrência de "etc" e reticências, ou seja, há uma marcação dupla da continuidade da informação. Em relação à argumentação, esse recurso pode trazer imprecisão informacional e, consequentemente, enfraquecimento do argumento. Outra possibilidade, sobretudo nos exemplos a seguir, é que a enumeração em si seja um recurso para esticar um pouco o argumento, e as reticências serviriam para alongá-lo um pouco mais.

5iPT130 - Isso poderia acontecer porque o índio não está acostumado com cidades, carros, ruas ..., e você não está acostumado com leões, animais selvagens, florestas...

5iPT137 - As aldeias estão vem mais modernas, com televisão, fornos... coisas da nova geração. // (...) Um dos motivos é que suas línguas estão desaparecendo pois estão aprendendo outras línguas como português, inglês ... 5iPT139 - Hoje em dia a cultura dos índios está acabando. Eles estão comprando televisão, carro etc... 
A análise da fala justifica esse uso das reticências, tão comum nos exemplos. Essa estrutura é uma das que mais evidencia a relação entre entonação e pontuação. A figura a seguir representa a análise do trecho "porque esses pensamentos ficam voltando e algumas vezes são pensamentos negativos ou pensamentos de frustração, de mágoa, também fazem muito mal”. Para uma clara noção da enumeração na fala, será apresentada a análise apenas do trecho em que ocorre a enumeração, seguida da palavra que a sucede, ou seja. "pensamentos de frustração, de mágoa, também".

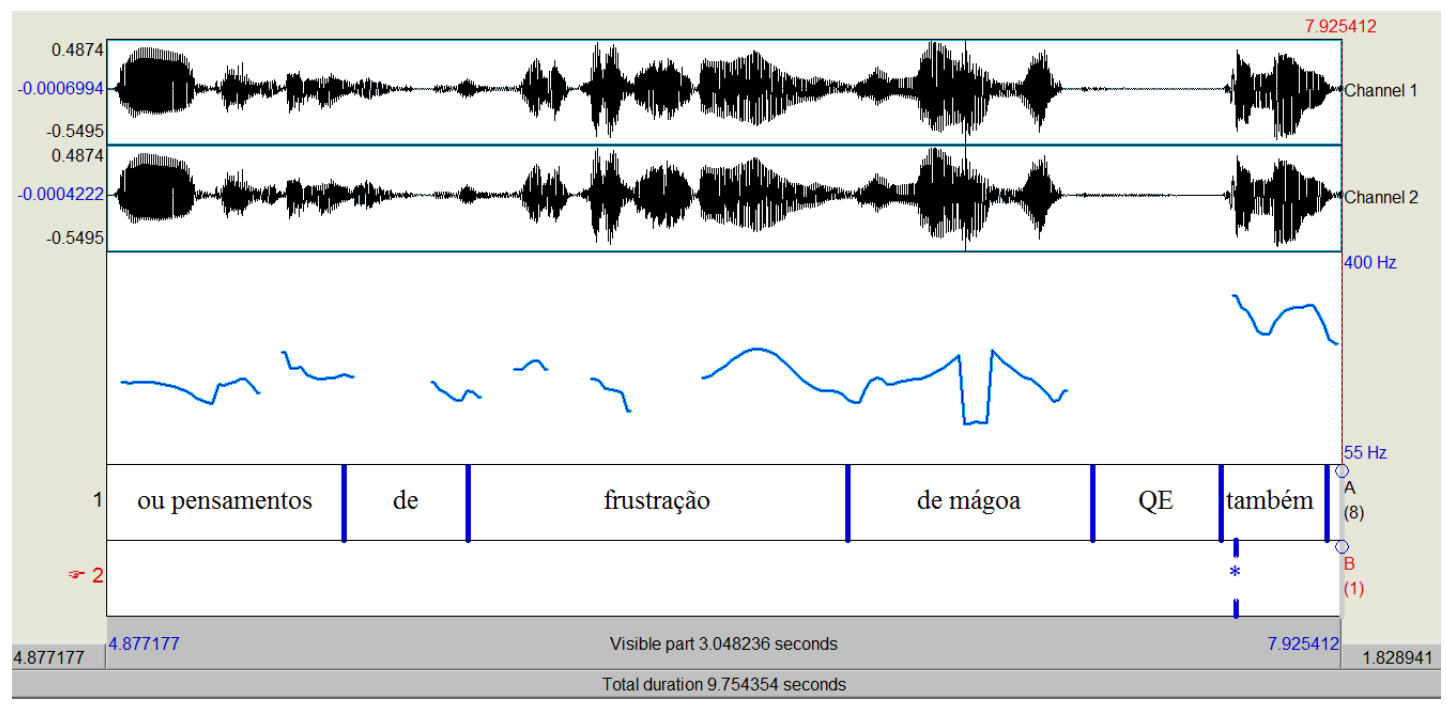

Figura 44 - PRAAT 10

É interessante observar que entre os termos da enumeração, “de frustração, de mágoa”, não há quebra entonacional, assim, não há motivação prosódica que justifique o uso de vírgula ali. Mas há a marca que indica a continuidade da enumeração, depois de seu último item, local em que o aluno de sexto ano colocaria as reticências, como pode comprovar o exemplo 5iPT137. Assim, essa análise indica que as reticências podem ser percebidas como sendo de motivação prosódica, enquanto o uso da vírgula é de motivação sintática, tendo em vista que não há quebra entonacional entre um item e outro da enumeração, contrariando, inclusive, os ensinamentos de Abreu (2003), que afirma existir quebra entonacional entre termos da enumeração. Como apenas uma sentença foi identificada no texto falado e analisada, pode-se considerar que há necessidade de mais dados para uma conclusão mais categórica sobre isso. 


\section{Uso de vírgula entre o verbo e os argumentos verbais - Sujeito e Objetos}

Quando se pensou nesta pesquisa e na análise da relação entre pontuação e prosódia, acreditava-se que haveria, nos dados escritos, alta ocorrência de uso de vírgulas para separar sujeito e objetos de seus verbos. Assim, a analise entonacional poderia justificar esse equívoco por parte dos alunos do sexto ano. Contudo, os dados escritos indicaram que apenas treze redações apresentaram vírgula entre sujeito e verbo, e cinco apresentaram vírgula entre verbo e objeto, um quantitativo abaixo do esperado para a fase escolar em foco.

O exemplo a seguir mostra uma ocorrência de vírgula entre sujeito e verbo. Nele o aluno usou um sujeito que apresenta dois itens em sua estrutura "algumas" e "pessoas", e há a vírgula separando-os do verbo ter. Uma hipótese de justificativa para esse uso equivocado da vírgula é que sujeitos mais robustos, como os oracionais, propiciariam, na fala, uma quebra entonacional entre o verbo e seu sujeito. Contudo, o exemplo em foco demonstra que sujeitos simples também podem ser isolados de seus verbos por vírgula. Os dados escritos não apresentaram o uso da vírgula após sujeitos formados por apenas uma palavra, o que deixa em aberto a possibilidade de o aluno considerar que duas palavras lexicais em um único termo sintático já o torne robusto.

5aPT017 - Algumas pessoas, têm preguiça de ler!

No capítulo 1 deste trabalho, foi mencionado que, em sua Gramática Mínima, Abreu (2003: 252) afirma que não há “quebra de ligação entonacional entre o sujeito e o verbo e entre o verbo e seus complementos". Porém, nesse capítulo, inicia-se o questionamento sobre os sujeitos oracionais, que podem passar pelo processo de empacotamento sintático-prosódico e provocar uma quebra prosódica entre o sujeito, oracional, e seu verbo. Aqui, neste capítulo, essa ideia será desenvolvida, com base em exemplo do corpus de fala.

$\mathrm{Na}$ fala de Bel Pesci, ocorreu a seguinte sentença, que será analisada acusticamente, a seguir: "Toma alguma atitude, para que aquilo que está virando uma repetição na sua cabeça possa não ficar te matutando na sua cabeça como está fazendo". Nesse trecho, observa-se a presença do verbo 'poder', utilizado no modo subjuntivo “possa”. Seu sujeito é a oração “aquilo que está virando uma repetição na sua cabeça", e seu objeto também é oracional, "não ficar te matutando na sua cabeça". Sintaticamente, sujeito e objeto não podem ser separados do verbo 
por vírgula, porém é comum verificar o uso equivocado da referida pontuação em textos escritos.

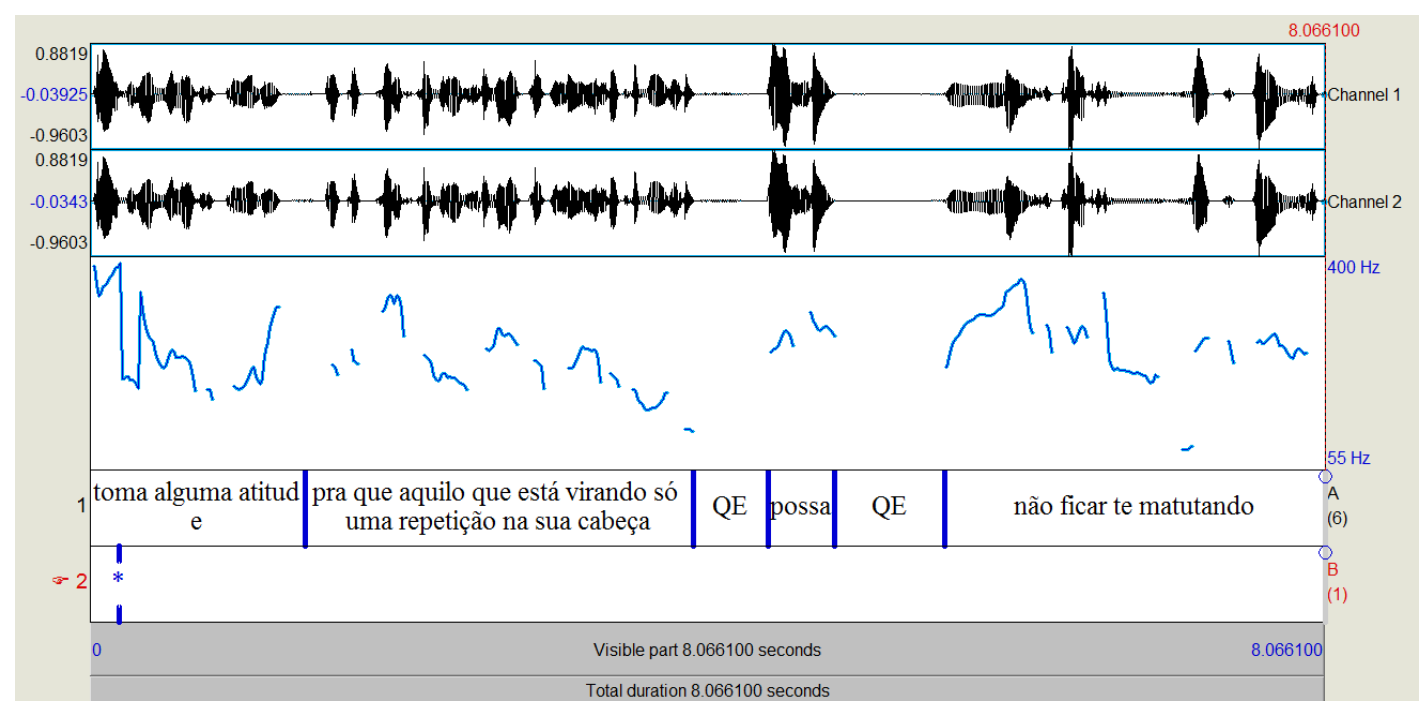

Figura 45 - PRAAT 11

A figura PRAAT 11 representa a fala do trecho mencionado no parágrafo anterior. Notase que, contrariando o ensinamento de Abreu (2003), a sentença apresenta duas quebras entonacionais: uma entre sujeito e verbo, e outra entre verbo e objeto. Ou seja, o verbo "possa" se localiza entre dois empacotamentos prosódico-sintáticos. Dessa forma, pode-se afirmar que não separar o verbo de seus complementos diretos é uma exigência estrutural, percebida pelos alunos do sexto ano, pelo que indica a baixa ocorrência de problemas dessa natureza.

Porém, o texto oral analisado demonstra que, nesse caso, o uso equivocado de vírgula pode ter motivação prosódica, tendo em vista as quebras entonacionais bem marcadas entre sujeito oracional e verbo, verbo e objeto oracional. As pausas, nesse caso, podem ter sido motivadas pela extensão tanto do sujeito, quanto do objeto direto, pois não são termos simples, mas sim orações subordinadas.

Com tudo o que foi apresentado sobre o uso da pontuação e sua relação com a entonação, percebe-se que explicar e justificar o uso da vírgula pela presença de pausa na fala é temerário. Os dados indicaram que há casos em que a correspondência entre entonação e pontuação é real, e há casos em que não, por isso é preciso extrapolar essa noção e tratar a vírgula, principalmente, como componente sintático da língua. As respostas dos questionários dos alunos indicam que é muito forte a compreensão de que a vírgula na escrita corresponde a pausas na fala, o que pode ser exitoso em diversos casos de uso dessa pontuação, como foi demonstrado anteriormente. Porém, como mencionado, é preciso ir além, pois as pausas não sustentam 
algumas exigências de uso da vírgula, assim como leva o aluno ao erro, como foi demonstrado em PRAAT 11. 


\section{Capítulo 5 - Propostas pedagógicas}

A aula de português seria então um exercício contínuo de descrição e análise desse instrumento de comunicação. Para isso, várias estratégias podem ser utilizadas, entre elas, a de levar o aluno a reconhecer a variação inerente à língua que faz com que cada grupo social possua sua própria variedade, mas ao mesmo tempo seja capaz de conviver com todas as outras. Callou, 2009: 27.

Analisar dados produzidos em sala de aula é uma atividade que provoca reflexão sobre a prática docente e gera o desejo de tentar solucionar os pontos críticos encontrados. Quando se faz uma análise de erros, isso se potencializa; por essa razão aqui serão propostas algumas intervenções didáticas baseadas nos resultados apresentados e discutidos no capítulo anterior. Algumas das propostas foram aplicadas aos alunos investigados neste trabalho; assim, seus resultados serão também mostrados aqui.

Os documentos oficiais abordados no Capítulo 2 indicam que o ensino de Língua Portuguesa deve se pautar na dinâmica Uso $\rightarrow$ Reflexão $\rightarrow$ Uso, em que a língua usada pelo aluno passa por uma reflexão a partir da análise linguística e retorna ao uso pelo aluno. Esse uso pressupõe comunicação, interação, e redações escolares tradicionais, por exemplo.

É importante frisar que, quando se trata de língua escrita, não há como deixar de considerar o uso da norma padrão. O livro didático adotado pela Escola Internacional aborda essa questão logo em seu primeiro capítulo, pois o aluno precisa saber que ela existe e porque ela existe e que, diariamente, os próprios estudantes a utilizam. É comum encontrar docentes enfatizando que o ensino de gramática não é útil aos alunos, mas esta pesquisa demonstra que, em alguns casos, é necessário haver o ensino, por exemplo, de regras de pontuação. Quando se usa a língua portuguesa em uma interação, usa-se a norma padrão, em alguma medida. Não se pode negar que até os mais eruditos, em alguns momentos, podem acabar cometendo algum desvio no uso dessa norma, mas não há como negar sua existência, tampouco a necessidade de se ensiná-la.

Acredita-se, sobretudo após a análise dos dados, que o problema não é a norma, mas, sim, como ela é trabalhada em sala de aula. Pouco eficiente em sala de aula é usar a metalinguagem, é trabalhar a língua de forma descontextualizada, é expor o aluno a um conteúdo, sem enfocar a importância desse conhecimento para a vida cotidiana. Da mesma maneira, é pouco eficiente apontar os desvios que o aluno comete em relação à norma padrão, condená-los e não realizar um trabalho para que esses erros sejam menos recorrentes.

A proposta dos PCN vige desde 1998, e os dados demonstraram que a efetividade das práticas definidas é questionável, já que o uso da língua, mesmo após o processo de reflexão, 
não é o esperado. Assim, é importante pensar em adaptações do modelo proposto pelos PCN e reafirmado pela BNCC para que resultados efetivos possam emergir.

A teoria que fundamenta esta pesquisa $(U B L)$ defende que a gramática de uma língua é organizada cognitivamente a partir da experiência do falante com a linguagem. Assim, pode-se compreender que, se o aluno tem experiências frequentes com a língua portuguesa escrita padrão, que é a enfocada na escola, essas poderão gerar um efeito positivo cognitivamente. Esse efeito positivo poderia ser a aquisição de estruturas próprias do texto escrito sem parecer artificial para o aluno, que tem a fala como sua língua de referência.

Bybee (2005) ensina que a frequência de uso das construções linguísticas, sobretudo as mais complexas, tem impacto em sua representação. Isso, para a linguista, fica evidente nas convenções de fala, naquilo que o falante reconhece como natural ou não em sua língua. Um exemplo disso são as gírias. Se certa palavra é utilizada por um grupo de fala, ela apresenta alta frequência de uso e, portanto, é reconhecida pelos falantes pertencentes àquela comunidade. Contudo, a mesma palavra pode causar estranhamento a um falante externo àquele grupo, simplesmente por não lhe ser familiar, ou seja, ter baixa, ou nenhuma, frequência de uso daquele termo. Vale ressaltar que o exemplo dado toma como base que os falantes mencionados tenham a mesma língua materna, e apenas pertençam a grupos de falas distintos.

Com base nesses pressupostos, acredita-se que à escola não cabe promover apenas a reflexão sobre o uso da língua, mas sim intervir sistematicamente sobre ele. Dessa forma, partese da língua em uso pelos alunos, sobretudo na oralidade, passa-se por uma reflexão daquele uso, comparando-o com padrões de uso de alto nível, o professor intervém nesse uso por meio de atividades que evidenciem as diferenças entre o que o aluno produz e o que se espera dele, e, por fim, parte-se para o uso da língua, que, com base nas interferências do professor, deverá estar mais próxima à língua padrão, própria da escola. Assim, propõe-se uma adaptação ao fluxo apresentado nos PCN e na BNCC, para Uso $\rightarrow$ Reflexão $\rightarrow$ Intervenção Docente $\rightarrow$ Uso Incrementado. $\mathrm{O}$ esquema a seguir ilustra a proposta. 


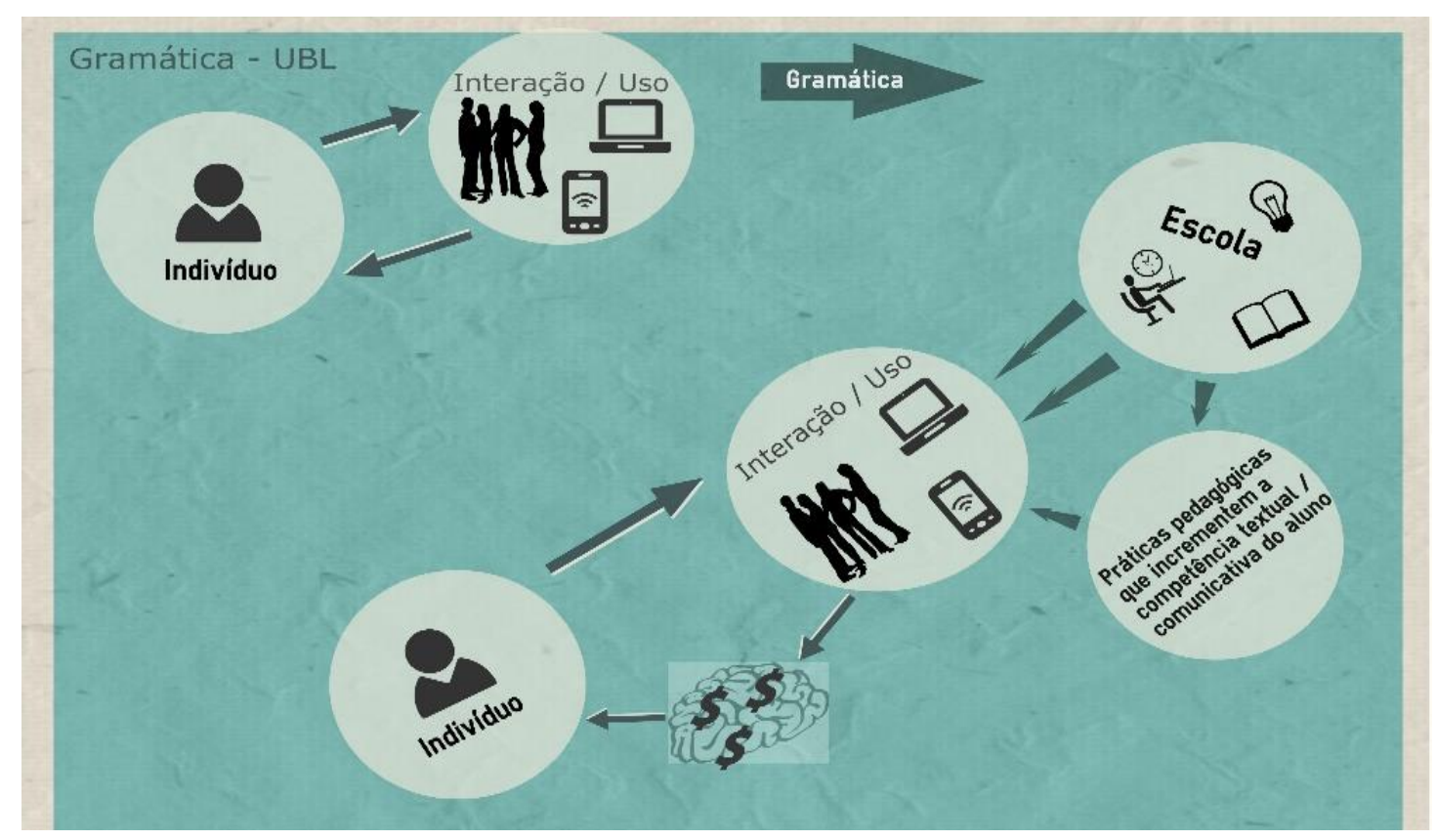

Figura 46 - Uso, Reflexão, Intervenção, Uso. Esquema.

A premissa inicial da representação proposta na figura apresentada é que a gramática de uma língua, independentemente de ser considerada como materna ou estrangeira, se consolida, se solidifica no uso, em um movimento cíclico. Na primeira representação da figura, tem-se a relação defendida por Bybee (2005), já mencionada, de que a frequência de uso colabora para a consolidação da gramática. Assim, um indivíduo que é exposto ao uso da estrutura 'Nós gosta de jogá bola', como motivação, armazena esse conhecimento e passa a usá-la em sua interação. No uso, esse indivíduo começa a testar hipóteses a partir dessa estrutura, e produz, então, 'Nós gosta de cantá', 'Nós vai estudá', entre outras possibilidades. Com o tempo de uso, essa estrutura vai se consolidando com a forma padrão. Quando ele chega à escola e a professora ensina, via análise linguística ou ensino tradicional, que o correto é usar a estrutura "Nós gostamos de jogar bola”, essa não tem sentido. Além disso, ela é usada com uma frequência baixíssima pelo o aluno, provavelmente restrito ao ambiente escolar e aos textos escritos para aulas de Língua Portuguesa. Como o indivíduo não usa a estrutura tida como padrão escolar, essa não tem impacto em sua representação, e, assim, o conteúdo relativo à concordância verbal e (ou) conjugação verbal é apenas algo que deve ser estudado para a prova.

A segunda representação na figura faz menção à escola e ao papel do professor de Língua Portuguesa. Assume-se, então, o uso como elemento central na representação da estrutura, por isso é no uso que o professor deve agir. $\mathrm{O}$ docente identifica o ponto a ser trabalhado no uso da linguagem pelo aluno, promove a reflexão sobre ele, via análise linguística, e intervém na maneira de se usar tal estrutura. Essa intervenção se dá por meio de 
ações que incrementem o uso textual (linguístico) do aluno, com criação de condições para a utilização da estrutura que se quer aprimorar no aluno. Com isso, amplia-se a frequência de uso, o que possibilitará, que a estrutura, até então utilizada, seja reconfigurada cognitivamente.

No contexto em que a pesquisa foi desenvolvida, ampliar as condições de uso foi possível através das novas tecnologias de informação e comunicação que estavam, naquela escola, presentes em sala de aula. A implementação de redes sociais educacionais para fins didáticos e de aplicativos, também com esses fins, proporcionaram a expansão do contexto de uso da língua escrita tida como padrão pela escola e também da interação entre alunos, entre si, e com a professora de Língua Portuguesa. Assim, serão apresentadas propostas de intervenção para promover a reconfiguração de uso da língua pelos alunos, com base em problemas identificados na análise de dados, acerca dos erros dos alunos.

\section{Problema 1 - Ortografia}

Um dos conteúdos a serem trabalhados na segunda etapa (segundo bimestre letivo) era a relação entre letra e som. No início do trabalho com o conteúdo, percebeu-se que os alunos não tinham consciência dos problemas que essa relação pode causar às suas produções escritas. Para conscientizá-los, foi criado um personagem que produzia, em seus textos escritos, incorreções relativas à grafia das palavras, motivadas pela não correspondência entre fala e escrita.

Os dados desta pesquisa, como apresentado no capítulo anterior, indicaram que a grafia das palavras, incluindo a acentuação, é o principal problema relacionado à escrita dos alunos

do sexto ano. É importante considerar que grande parte dessa questão deveria ter sido resolvida na fase de alfabetização, o que não ocorreu. A BNCC propõe um trabalho expressivo com a apropriação do sistema de escrita alfabético/ortográfico no primeiro ano da Educação Infantil. Os objetivos que os alunos devem alcançar, nessa fase escolar, seguem na figura a seguir apresentada. 
LILP1FOA025. Compreender o funcionamento do sistema de escrita alfabética;

LILP1FOA026. Reconhecer e nomear letras do alfabeto distinguindo-as de outros sinais gráficos;

LILP1FOA027. Reconhecer diferentes tipos de letras em diferentes contextos, suportes e gêneros textuais;

LILP1FOA028. Realizar análise fonológica de palavras, segmentando-as oralmente em unidades menores (partes de palavras, silabas), identificando rimas, aliterações, observando a função sonora que os fonemas assumem nas palavras, relacionando os elementos sonoros com sua representaçâo escrita;

LILP1FOA029. Reconhecer que as silabas variam quanto à sua combinação entre consoantes e vogais (CV, CCV, CVV, CVC, V,VC, VCC, CCVCC) e que as vogais estão presentes em todas as silabas;

LILP1FOA030. Compreender que alteraçōes na ordem escrita dos grafemas provocam alteraçōes na composição da palavra;

LILP1FOA031. Ler, ajustando a pauta sonora ao escrito;

LILP1FOA032. Ler palavras e textos, apoiando-se em imagens;

LILP1FOA033. Escrever o próprio nome e utilizá-lo como referência para escrever e ler outras palavras, construindo a correspondência fonema/ grafema;

LILP1FOA034. Escrever palavras e textos, segundo sua compreensão do sistema alfabético, ainda que não convencionalmente;

LILP1FOA035. Reconhecer palavras e frases frequentes em textos, sem a necessidade de decodificação;

LILP1FOA036. Reconhecer palavras em textos, a partir de alguns índices sonoros e suas correspondèncias gráficas;

LILP1FOA037. Ler oralmente textos familiares e curtos (titulos de histórias, manchetes, quadrinhas, entre outros) após leitura silenciosa;

LILP1FOA038. Dominar correspondências entre letras ou grupos de letras e o seu valor sonoro, construindo a correspondência fonema/grafema- grafema/fonema de modo a ler e escrever palavras e textos;

LILP1FOA039. Ler, ajustando a pauta sonora ao escrito;

LILP1FOA040. Conhecer o uso de variados tipos de letras, de suportes e instrumentos de escrita (papel, lápis/caneta, tela/ teclado);

LILP1FOA041. Manusear adequadamente livros didáticos e de literatura e outros suportes frequentes no contexto social;

LILP1FOAO42. Compreender os modos de organização da biblioteca da turma.

Figura 47 - Base Nacional Curricular Comum - páginas 48 e 49.

Os objetivos mostrados anteriormente são apresentados sob o título de "Apropriação do sistema de escrita alfabético/ortográfico e tecnologias da escrita", e apontam para o desejo de 
se formar cidadãos que saibam escrever adequadamente, o que, atualmente, não acontece com eficiência. Se, na Escola Internacional, a fase de alfabetização tivesse enfocado com mais vigor a relação som/letra, os resultados desta pesquisa teriam sido diferentes. O que causa preocupação é que a escola em foco, como mencionado no Capítulo 3, atende a uma clientela de grande poder aquisitivo, e, ainda nesse contexto, os objetivos relativos à apropriação do sistema alfabético não são alcançados.

Retomando o primeiro parágrafo desta seção, por meio da personagem criada, a professora conseguiu conscientizar os alunos para os problemas ortográficos por eles cometidos. Em seguida, elaborou uma situação problema em que os alunos eram professores da personagem e deveriam identificar as causas dos erros ortográficos, propor uma aula e atividades que visassem melhorar o desempenho da aluna hipotética. Esse processo deveria ser realizado por meio de pesquisas em materiais didáticos de referência e cada passo do trabalho precisava ser registrado na rede social educativa utilizada pela escola ${ }^{50}$. Os registros, na rede, deveriam ser feitos - conforme instruções e normas de utilização definidas e divulgadas pela professora do grupo, logo no início dos trabalhos com esse recurso - com o uso de escrita formal, com o máximo de correção possível, e um aluno poderia corrigir o outro em caso de grafia equivocada ao longo dos relatos na rede. A atividade culminou nas aulas com exercícios, que os alunos, organizados em grupos, apresentaram, e envolveram a turma toda.

A partir da intervenção, que objetivou ampliar as condições de uso da escrita correta, os alunos conseguiram melhorar alguns problemas dessa natureza. Vale destacar que monitoramento constante e atividades frequentes de correção da grafia foram desenvolvidos a partir da atividade problema (pontapé inicial do trabalho com ortografia no sexto ano). Como nessa fase os alunos respondem bem aos estímulos visuais, esses foram explorados na tentativa de incentivar a frequência de uso e o contato com a grafia correta de palavras com índices elevados de desvio, como nas em que o som da letra 's' pode ser representado por mais de uma letra.

\footnotetext{
50 Desde o início do ano letivo 2014/2015, a Escola Internacional decidiu adotar, como recurso didático, a plataforma de ensino online Schoology - disponível em https://www.schoology.com/home.php.
} 


\section{Problema 2 - Paragrafação}

Logo nas primeiras atividades do ano letivo em que o uso da língua escrita era o foco, foi identificada a paragrafação como ponto sensível, que demandaria investimento didático, do grupo de alunos do sexto ano. Iniciou-se, então, um longo percurso em prol de textos argumentativos melhores organizados. Como os dados comprovam, era muito comum a produção de parágrafos formados por frase única. Essa geralmente era confusa semanticamente e prejudicada em relação à sua estrutura. O exemplo abaixo ilustra essas características.

Eu achei o livro "Yakima" muito bom apesar de , no incío quando o caso estava sendo explicado, eu achei um pouco parado, a forma como o escritor teve a criatividade o bastante de escrever um livro como esse é impressionante retratando os fatos da realidade e ao mesmo tempo nos ensinando um pouco sobre como os indios no brasil se comportam e como vivem eu adorei!!!!!!!!!!!!

Tue Sep 16, 2014 at 7:11 pm · Like · Reply

Figura 48 - Exemplo de Paragrafação, Aluno 1, Etapa 1.

Nessa tarefa, os alunos deveriam produzir um parágrafo em que apresentassem sua opinião sobre o livro lido ao longo da etapa 1 (primeiro bimestre). Essa atividade foi realizada pela plataforma educacional que a escola usava, Schoology. É importante considerar que a produção proposta é comum aos alunos em foco, já que são nativos digitais e se comunicam frequentemente por meio de comunidades online. Assim, a ampliação de uso da língua escrita foi realizada por meio de uma situação plausível, com o auxílio da tecnologia. Atividades como essa revelaram o problema de organização das ideias, que foram trabalhados sistematicamente.

Sobre paragrafação, as respostas do questionário revelaram que os alunos, apesar de usarem essa estrutura em seus textos, não tinham real noção de sua função e de como ele deveria ser organizado, o que, mais uma vez, revela a manutenção de um ensino que não se converte em uso efetivo para o aluno. Como não sabiam exatamente o que era e qual a função de um parágrafo, os alunos o estruturavam como julgavam conveniente. Para alterar esse uso assistemático do parágrafo e tentar modificar a percepção dos alunos em relação a essa estrutura, algumas intervenções didáticas foram realizadas. 
Iniciou-se o trabalho pela análise de um texto argumentativo, elaborado pela docente, cumprindo uma proposta de produção de texto aplicada aos alunos. Durante a análise, os alunos foram apresentados ao que a professora definiu como o parágrafo padrão para eles. Foi esclarecido que aquele seria o padrão para aquele momento didático, para o nível de ensino em que o grupo se encontrava, com o objetivo específico de atender às necessidades do grupo, e que não se tratava de um padrão universal e inalterável.

Após essa etapa, os alunos passaram a desenvolver parágrafos guiados, os quais seriam formados pelas respostas a algumas orientações específicas. Seguem-se trechos de material produzido pela docente para a prática de produção textual monitorada.

\section{Brasília, terra de contrastes?}

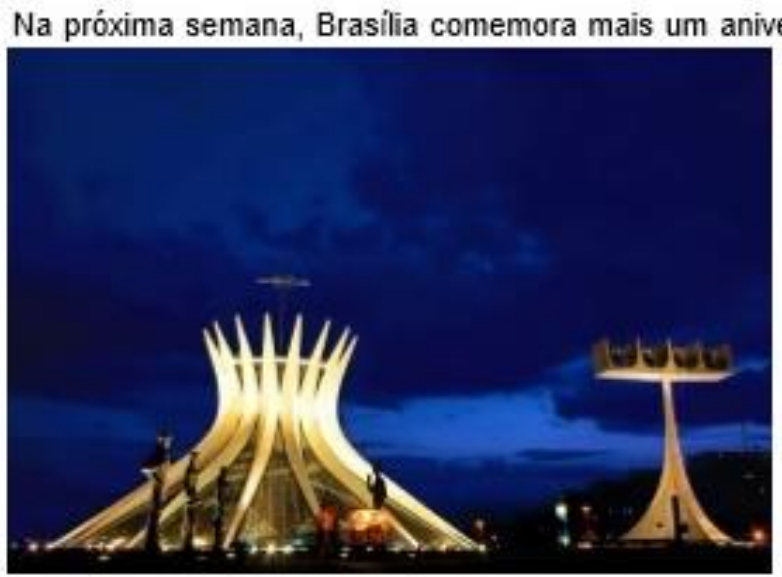

Vamos aproveitar o momento e fazer uma reflexão sobre nossa cidade, diversidade e peculiaridades.

Assim, siga as recomendações seguintes.

\section{Tarefa 01}

Reflita um pouco sobre sua vida em Brasília. A partir disso, escreva nos comentários da postagem sobre esta atividade, no nosso blogue

3 aspectos positivos (vermelho) e 3 aspectos negativos (azul) de Brasilia. Em seguida, no mesmo texto, escreva: o que você daria de presente para a cidade (roxo)? Você pode se

inspirar no exemplo abaixo.

Sugestão

Brasillia tem de positivo a arquitetura, os grandes espaços verdes - como o Parque da Cidade -e as boas oportunidades de emprego. Em compensação, a diferença social entre o Plano Piloto e as cidades satélites é muito grande. Além disso, o transporte público e o sistema de saúde são outros dois pontos negativos dessa cidade. No dia 21 de Abril, presentearia Brasilia com melhores governantes, que possam dar ao povo, que aqui mora, boas condições de vida e de crescimento social e econômico.

Figura 49 - Proposta Didática: paragrafação 1.

Mais uma vez, a tecnologia foi importante nessa intervenção, pois os alunos precisavam produzir uma postagem para o blogue que o sexto ano desenvolveu (e que foi retirado do ar no final do ano letivo). O trabalho com conjunto de atividades sobre o aniversário de Brasília foi iniciado em sala de aula, durante a etapa 4 (quarto bimestre letivo), para que os alunos pudessem contar com o auxílio e com a intervenção da professora. A finalização seria realizada em casa, para ampliar o tempo de uso da língua escrita padrão. A seguir, há o resultado da progressão do 
Aluno 2, com um trecho de produção realizada na primeira etapa e o produto dessa atividade sobre o aniversário de Brasília.

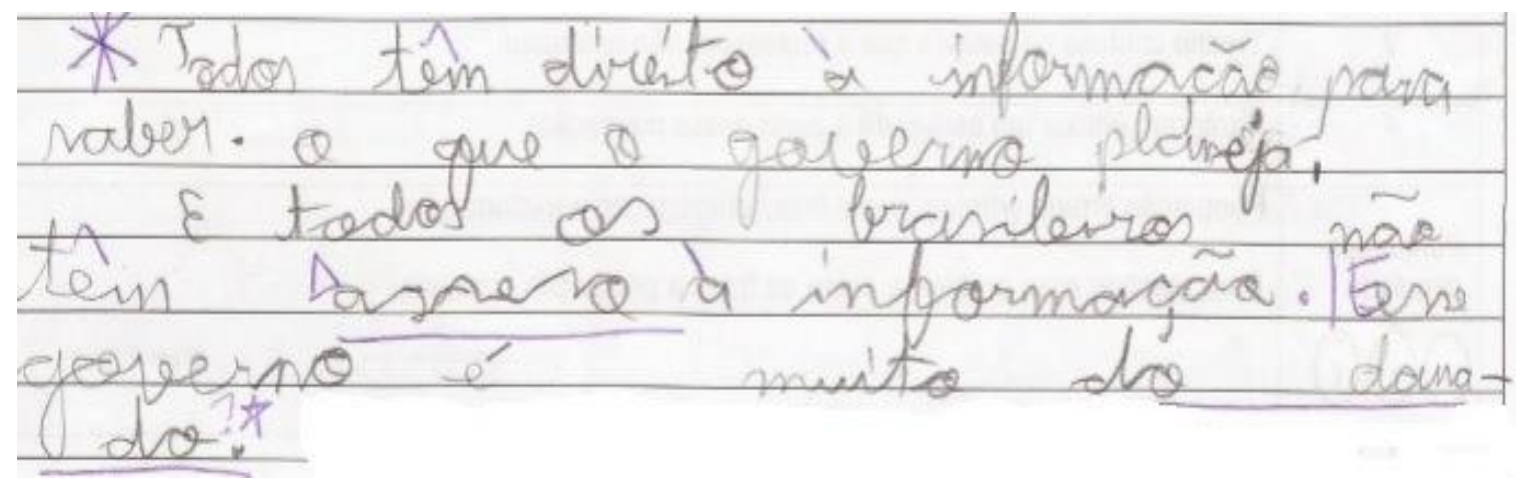

Figura 50 - Exemplo: Aluno 2, Etapa 1



Figura 51 - Exemplo: Aluno 2, Etapa 4.

Apesar de problemas de ordem coesiva, o aluno apresenta incremento na organização textual e uso mais adequado do parágrafo. Esse aluno, claramente, precisa continuar investindo no trabalho com a produção de texto, mas já demonstra que o esforço feito e a intervenção no uso da língua influenciaram a estrutura e modificaram o uso e promoveram um incremento na estrutura linguística utilizada, mais próxima à língua escrita padrão.

Resultado semelhante, mas de melhor qualidade, obteve o Aluno 1, do primeiro exemplo desta seção, que apresentava um parágrafo formado por uma única frase, na qual apresentava sua opinião sobre o livro lido no mês de setembro de 2014, "Yakima: o menino onça". O exemplo a seguir mostra um parágrafo de sua produção de texto acerca do livro "Não se esqueça da rosa", tema da avaliação da terceira etapa letiva. É importante notar que a primeira produção foi realizada, pelo Aluno 1, em casa e que o exemplo abaixo foi produzido em sala de aula, em momento de avaliação. 
"O livro, na verdade, é um reflexo do mundo real. A bomba aconteceu de fato. E milhares de pessoas morreram. Tudo que diz respeito à história mundial no livro é verdade. Só Hanako foi inventada, para mostrar as consequências da bomba. Eu achei a história muito interessante porque continha muitas informações históricas e o fato de ela ter desenvolvido uma doença foi preciso e deu emoção ao texto. Eu acho que a autora do livro usou bem seu conhecimento como escritora para produzir a estrutura do livro, pois ela soube onde por os parágrafos, e, acima de tudo, ela soube empregar a função de cada coisa. Eu colocaria mais detalhes sobre a doença e menos ladainha sobre a morte que estava próxima. E, por fim, eu recomendaria esse livro para pessoas sensíveis, que gostam de histórias de drama".

- Aluno 01 (Etapa 03)

Figura 52-Exemplo: Aluno 1, Etapa 3.

O trecho acima traz o último parágrafo do texto. Na finalização de sua análise da história narrada, os alunos precisavam comparar a história mundial com os fatos do livro, apresentar sua opinião e fazer a recomendação da obra. Apesar de tratar de um parágrafo em que vários assuntos são abordados, o parágrafo apresenta organização bastante diferente da realizada na primeira etapa letiva, o que confirma a importância da intervenção docente no processo de aprendizagem do texto escrito.

\section{Problema 3 - Pontuação}

O último ponto sensível que será discutido é a pontuação. A análise dos dados relativa a esse macrocritério revelou informações importantes acerca do uso da vírgula. As respostas dos alunos, acerca da pontuação, no questionário, indicaram que o conceito trabalhado com os alunos até então é temerário e conduz a uma visão simplista e, em alguns casos, equivocada da pontuação.

Nos questionários, os alunos revelaram entender que a vírgula é uma pausa pequena no texto e que o ponto final é uma pausa maior. Afirmaram que essa pausa é para garantir a respiração do leitor. Além disso, como apresentado no capítulo anterior, assim como no caso do parágrafo, os alunos não conhecem a motivação do uso da pontuação, ou seja, utilizam-na de forma irrefletida, apesar de não ter ocorrido, nos dados, algum texto totalmente sem o uso de pontuação. É importante que os alunos sejam ensinados, desde o início de seu trabalho com 
a pontuação, que a vírgula é uma necessidade da estrutura do período, sendo muito importante para separar constituintes sintáticos.

O principal ponto a ser investigado pelo macrocritério Pontuação foi a relação entre a pontuação e a entonação. Nessa análise foi possível perceber que nem sempre a vírgula representa, verdadeiramente, uma pausa, fazendo com que a definição reproduzida pelos alunos caia por terra. Há casos em que a sintaxe exige o uso da vírgula, que não é equivalente a pausas na fala. Em outras ocorrências, o contrário acontece, a fala indica pausa, e a sintaxe pede continuidade da estrutura, como entre sujeito e verbo de uma oração. O que chama atenção, também, são as ocorrências em que a entonação marca, de forma clara, a pausa e o aluno não a transporta para seu texto escrito, talvez por não confiar em sua intuição de falante nativo.

No que diz respeito à pontuação, não há experiências realizadas com as turmas em foco para se apresentar os resultados, contudo serão feitas algumas sugestões de atividades que poderão ser aplicadas em sala de aula. Os dados indicaram que a maioria das vírgulas utilizadas, no texto escrito, é motivada pela quebra entonacional na fala. Assim, se o aluno for treinado a perceber essa relação, haverá maiores índices de correspondência à norma padrão da língua escrita do que se ele se pautar em outros critérios - isso no caso dos alunos do sexto ano.

Dessa forma, é preciso treinar os alunos na análise do texto oral, para que relacionem entonação e texto escrito, ou seja, para que valorizem os conhecimentos que já detêm acerca da gramática da língua, e os adapte às peculiaridades do texto escrito escolar. Para isso, o professor pode solicitar aos alunos que gravem trechos de conversas para que possam partir da análise de suas próprias produções de texto oral e percebam como usam as pausas como recurso discursivo. O seguinte passo seria apresentar aos alunos um texto originalmente produzido pela linguagem oral, transcrito, e pedir que os alunos indiquem as vírgulas e os pontos finais na transcrição, a partir da audição. Com isso é possível aferir a percepção dos alunos em relação às pausas da fala, para que eles possam perceber que a vírgula não representa uma pausa para respirar, como parte do grupo afirmou nos questionários. O professor pode, também, partir da oralidade para traçar, com os alunos, as regras de uso da vírgula, com base nas pausas identificadas.

Os alunos precisam também entender o uso da entonação para o discurso, por isso é importante ensiná-los a perceber a intenção comunicativa por trás das pausas, para realçar a informação seguinte, por exemplo. Essas ações podem guiar os alunos a alterar sua percepção sobre o uso da pontuação, que é das mais complexas possível, segundo o dicionário. Com ações como as apresentadas, o aluno pode relacionar a pontuação a seu uso diário da linguagem. 
Os PCN, conforme apresentado no Capítulo 2 desta tese, enfoca a necessidade de se trabalhar com o texto oral de forma sistematizada. Nesse ponto, a proposta aqui feita também atenderia à recomendação desse documento, em que há a recomendação sobre o aluno reconhecer "a contribuição complementar dos elementos não-verbais", dentre os quais se inclui a entonação, no processo comunicativo. 


\section{Considerações finais}

A teoria selecionada para subsidiar o estudo empreendido definiu o desenho da tese apresentada. Foi o olhar no uso da língua portuguesa que motivou os instrumentos de coleta de dados que lançaram luz sobre as questões aqui enfocadas. Analisar o uso da língua dentro do recorte de público selecionado para a pesquisa trouxe novas nuances sobre velhas discussões a respeito do ensino do componente curricular Língua Portuguesa.

A análise do uso da língua portuguesa escrita fez com que o enfoque desta investigação fossem os desvios cometidos pelos alunos do sexto ano em relação à norma padrão escrita, colocando a análise de erros no centro metodológico do trabalho. A observação dos erros levou também à percepção dos acertos, e esses indicaram que os alunos, no nível em foco, têm consolidado muito mais conhecimento da língua escrita na norma padrão do que podem julgar alguns professores e os próprios alunos. Nesse viés, se eles já detêm grande parte da estrutura formal da língua, como, por exemplo, o uso dos tempos verbais no modo indicativo, como indicaram os dados deste estudo, não há necessidade de se deter no ensino desse conteúdo. É mais eficiente e desafiante, ao aluno, trabalhar, então, com a correlação entre os verbos do indicativo e do subjuntivo, por exemplo, conhecimento que eles ainda não têm consolidado, também de acordo com os dados.

Com o mapeamento dos principais problemas dos alunos do sexto ano da Escola Internacional, foi possível perceber que os alunos não apresentam problemas em relação a desenvolver textos argumentativos escritos que exijam um posicionamento crítico por parte deles. Coerentemente à faixa etária, o nível de argumentos utilizados não é equivalente a um aluno do final do Ensino Médio, mas é uma pedra bruta que deverá ser lapidada ao longo do Ensino Fundamental II. Na contramão dessa tendência dos dados, a BNCC e os materiais didáticos, para o sexto ano, recomendam o trabalho intensivo com textos de tipologia narrativa e deixam a argumentação para anos posteriores. Essa perspectiva é válida e interessante, porém, como o trabalho com uma tipologia não exclui a possibilidade de enfocar outra, é possível ter, também, a argumentação como prática no sexto ano. Uma justificativa para isso é que, na fala, os alunos, nessa faixa etária, argumentam o tempo todo, não havendo problemas, portanto, em enfocar essa tipologia também na escrita.

Com base no parágrafo anterior, é possível responder à seguinte pergunta de pesquisa desta tese: em que medida a tipologia argumentativa influencia na qualidade das produções de texto em alunos de sexto ano? Nota-se que trabalhar argumentação no sexto ano, seja em textos 
escritos ou orais, influencia positivamente o desempenho dos alunos, e faz com que eles exercitem, desde cedo, as capacidades crítica e analítica da realidade, o que colabora para a formação de cidadãos críticos e reflexivos. Para o trabalho com textos argumentativos, é possível promover situações de uso da língua coerentes com a faixa etária dos alunos, por exemplo, o trabalho com gêneros textuais como debate regrado, júri simulado, indicação de leitura e campanhas de conscientização. Assim, amplia-se o uso da norma padrão da língua e se exercita $\mathrm{o}$ ato de argumentar.

Os dados evidenciaram que a influência da língua falada em textos escritos ainda é muito frequente entre os alunos do sexto ano, sobretudo em relação à grafia das palavras. Acerca desse macrocritério, os dados corroboraram o que a ANA revelou em seus resultados, que a ortografia é um ponto crítico dos alunos brasileiros. Vale a ressalva de que tal avaliação é aplicada para alunos de terceiro ano do Ensino Fundamental I, e os dados desta pesquisa foram coletados com alunos do sexto ano (Ensino Fundamental II). Isso leva a concluir que o processo de alfabetização desses alunos foi pouco eficaz, e o fato de a escola ser da rede privada deixa a situação ainda mais grave. Nessa escola, é comum o aluno ingressar na Educação Infantil e ficar até o fim do Ensino Fundamental II, então é necessário olhar para os anos iniciais de formação (Educação Infantil e Ensino Fundamental I) para se tentar melhorar o desempenho dos alunos em relação à Escrita Formal.

Interferência da fala na ortografia está relacionada ao segmento fonológico da estrutura da língua, mas a relação entre fala e escrita não é observada só nesse nível. O suprassegmento, ou entonação, também influencia na escrita dos alunos de sexto ano. Acredita-se que, nesse nível, a influência não se dê apenas no âmbito dos alunos investigados, mas que a entonação influencie em textos escritos produzidos inclusive por adultos. É possível notar tal influência no que diz respeito à pontuação do texto escrito, mais especificamente no uso da vírgula. Os dados revelaram que a entonação mais ajuda do que atrapalha o aluno a pontuar seu texto corretamente.

A pontuação foi o principal ponto crítico identificado na estruturação de textos argumentativos, ficando à frente de problemas que se julgavam mais recorrentes, como a paragrafação. Sobre isso, as análises indicaram que a valorização da fala ao se abordar, em sala de aula, a questão da pontuação, poderia alterar os resultados aqui encontrados. O aluno demonstra não confiar em sua intuição de falante nativo da língua portuguesa para pontuar seu texto escrito, isso porque a oralidade não é privilegiada na escola na mesma medida do texto escrito. Assim é difícil atender às recomendações dos documentos oficiais de ensino, nos quais 
se lê que é preciso valorizar, em aula, a língua que o aluno traz de sua comunidade de fala, pois a língua que o aluno traz é a língua falada. Seguindo esse raciocínio, ela deve ser mais explorada, inclusive para o ensino de aspectos estruturais da língua escrita.

O fluxo da fala influencia também a organização das ideias, sobretudo no tamanho de frases e parágrafos. Nesses casos, entretanto, observa-se que a pontuação pode vir a ser prejudicada pelo tamanho do parágrafo, pois quanto maior a oração, maior são as chances de erros de pontuação serem cometidos. Sobre a influência da fala na escrita, mais especificamente em relação à pontuação, os dados orais analisados acusticamente colocaram em cheque a relação tão difundida de que a vírgula, na escrita, corresponde a uma pausa na fala, pois se mostrou que há sim algumas pausas na fala as quais correspondem a estruturas que não podem ser separadas por vírgulas na escrita. Essas pausas, então, provavelmente têm valor discursivo, o que não ajuda as prescrições das gramáticas tradicionais. As análises acústicas também mostraram que não há relação entre tamanho de pausa na fala e obrigatoriedade de uso do ponto final na escrita, e isso indica que ensinar para o aluno que a vírgula é uma pausa pequena e o ponto final uma pausa grande na leitura do texto é um equívoco.

Além da pontuação, a coesão também é comprometida pela transposição de estruturas da fala para o texto escrito. É comum, na oralidade, a repetição de algum termo, sobretudo do tema da comunicação ou do sujeito, até mesmo para efeito de ênfase; em contrapartida, na escrita, devem-se usar estratégias de referenciação para se evitar a repetição de palavras. Esse também foi um problema recorrente nos dados, mas compreende-se que recursos coesivos ligados à coesão referencial demonstram um refinamento no uso da linguagem ainda não adquirido por alunos da faixa etária em foco.

A abstração dos conceitos relativos à produção de texto também ficou evidente nesta pesquisa. Assim, ensinar ao aluno as noções de parágrafo e pontuação deve ser um processo cuidadoso, já que esses conceitos, tão importantes para a produção de textos escritos de qualquer tipologia, não são compreendidos efetivamente pelos alunos de sexto ano. Ficou claro que eles não sabem para que essas estruturas servem, portanto não lhes são úteis. E, se não lhes são úteis, para quê perder tempo com isso? Explica-se, portanto, o pouco apego que os alunos têm às aulas de produção de texto em geral.

Aliás, as análises feitas acerca da paragrafação foram importantes para delimitar o que e como a organização textual poderia ser trabalhada com os alunos de sexto ano. Tomar, em sala de aula nos anos iniciais do Ensino Fundamental II que a paragrafação é conhecimento prévio não é uma escolha profícua, pois tanto o questionário aplicado, quanto as produções de 
texto evidenciaram que o aluno de sexto ano não sabe para que serve e como se deve organizar um parágrafo. As estratégias apresentadas no Capítulo 5 sobre esse tema indicam que investir na sistematização desse conteúdo é significativo para a qualidade dos textos dos alunos.

A união dos dados com os pressupostos teóricos conduziu a uma reflexão sobre a prática do ensino de Língua Portuguesa em escolas brasileiras, como a Escola Internacional. Isso fez com que se fizesse necessária uma nova visita aos documentos oficiais, como apresentado no Capítulo 2, e também à BNCC. Assim, os dados indicaram a necessidade de se dar um passo adiante na proposta trazida pelos PCN, e na BNCC, de ensino de Língua Portuguesa, que apresentam o fluxo USO $\rightarrow$ Reflexão $\rightarrow$ Uso. Propõe-se, então, um incremento aos resultados promovidos pela reflexão, de forma que essa não retorne imediatamente para o uso, mas sim que promova uma intervenção por parte do docente, que deve ampliar as condições de o aluno usar a língua que lhe está sendo ensinada na escola, a escrita padrão. Essa ampliação do uso da língua que está sendo ensinada na escola pode ser feita com a criação de situações-problema em que sua solução seja feita por meio do uso da língua padrão escrita.

Demonstrou-se que a referida intervenção docente promoveu a melhora na estrutura textual dos alunos, de forma que a escola deve usar seu espaço para incrementar a frequência de uso da modalidade de língua em foco, tendo como base o pressuposto próprio da $U B L$ de que é a frequência de uso que constrói a gramática de um falante. Defende-se, então, que quanto mais se usa a língua escrita padrão, menos artificial ela se torna para o aluno, sobretudo no sexto ano. Assim, o esquema proposto pelos documentos oficiais seria reestruturado da seguinte forma: Uso $\rightarrow$ Reflexão $\rightarrow$ Intervenção Docente $\rightarrow$ Uso Incrementado, o que possibilitaria dar maior ênfase à produção textual. Isso se justifica no fato de que é a capacidade de compreender textos e produzir textos bem estruturados que o aluno da educação básica levará de mais produtivo para sua vida profissional, tendo em vista que a metalinguagem, ainda tão frequente em sala de aula, tende a ser esquecida ao longo do tempo. A eficácia do incremento proposto no modelo difundido pelos PCN pode ser verificada no trabalho com a paragrafação.

As evidências mostram que o atual formato do ensino do componente curricular Língua Portuguesa não está surtindo os efeitos desejados, claramente expressos nos documentos oficiais. Os PCN têm mais de uma década de existência e até hoje pouco do que ele propõe foi aplicado, o que fica evidente em escolas que, por exemplo, separam o ensino da Língua Portuguesa em três frentes: gramática, literatura e produção de textos ou redação. O modelo proposto nos PCN continua atual, tendo em vista que estão presentes nas propostas da Base 
Nacional Curricular Comum. Fica a esperança de que um dia ele seja de fato implementado e que traga bons e novos resultados à educação.

O ensino da norma padrão já foi muito debatido pela academia, e os dados indicam que ela deve ser ensinada, o que precisa ser repensado é como trabalhar com ela em sala de aula, além de tentar descobrir como torná-la mais natural e menos artificial para o aluno. Ademais, muito se tem pesquisado sobre o ensino da língua materna brasileira, inclusive nesta tese, mas a união entre universidades e a prática docente ainda é escassa. Por essas e outras questões é que aqui foram apresentadas novas nuances de antigos problemas.

A prática docente no Ensino Fundamental II ensina que o aluno do sexto ano tem uma incrível capacidade de assimilar os conteúdos. Assim, o que lhe for bem ensinado, será aprendido. Dessa forma, é importante pensar em um ensino que aproveite essa capacidade cognitiva e promova, com soluções realísticas e eficazes, condições para o desenvolvimento das competências em Língua Portuguesa. Assim, entende-se que é importante plantar no sexto ano os frutos que se deseja colher nas notas das redações do ENEM e, mais do que isso, para a vida profissional do aluno, pois é importante salientar que o ensino não deve ser planejado e pensado para uma avaliação, e sim para a vida do aluno, para torná-lo capaz de crescer enquanto cidadão, e ser verdadeiramente proficiente em sua língua materna, usando-a para alcançar seus objetivos comunicativos - pessoais, profissionais e sociais. 


\section{Referências}

ABRAÇADO, Jussara. Entrevista com Maria Margarida Martins Salomão sobre a Linguística Cognitiva e suas relações com outras ciências. Cadernos de Letras da UFF - Dossiê: Letras e cognição, no 41, p. 15-25, 2010

ABREU, Antônio S. Gramática mínima: para o domínio da língua padrão. Cotia, SP: Ateliê Editorial, 2003 [2012] $3^{\text {a }}$ edição.

ALONSO, Karen S, B. Construções binominais quantitativas e construção de modificação de grau: uma abordagem baseada no uso. Tese (Doutorado em Linguística) - Programa de PósGraduação em Linguística, Faculdade de Letras, Universidade Federal do Rio de Janeiro, Rio de Janeiro, 2010.

AZEREDO, José Carlos de. Gramática Houaiss da língua portuguesa. São Paulo: Publifolha, 2008.

BAKHTIN, Mikhail. Marxismo e filosofia da linguagem. 2a ed. SP: Hucitec, 2002.

BEAUGRANDE, Robert. Linguistic Theory: The Discourse of Fundamental Works. London: Longman, cap. 9, 1981.

BECKNER, Clay; BYBEE Joan. A usage-based account of constituency and reanalysis. In: Language Learning, 59: 27-46. 2009.

BRASIL, Guia de livros didáticos: PNLD 2014: língua portuguesa: ensino fundamental: anos finais. - Brasília: Ministério da Educação, Secretaria de Educação Básica, 2013.

BRASIL. Ministério da educação. INEP. A redação no Enem 2013 - Guia do participante. Brasília, 2013. Disponível em: http://download.inep.gov.br/educacao_basica/enem/guia_participante/2013/guia_de_redacao_ enem_2013.pdf Acesso em: 08 de abr. 2015.

BRASIL. Secretaria de Educação Fundamental. Parâmetros curriculares nacionais: terceiro e quarto ciclos do ensino fundamental: língua portuguesa/ Secretaria de Educação Fundamental. Brasília: MEC/SEF, 1998.

BROWN, Penélope. \& LEVINSON, Stephen. C.. Politeness: someuniversals in language usage. Cambridge: Cambridge University Press, 2000 [1987].

BYBEE, Joan L.; CHAKRABORTI, Paromita, JUNG, Dagmar; SCHEIBMAN Joanne. Prosody and segmental effect: Some paths of evolution for word stress. In: Studies in Language 22: 267-314. 1998 (B)

BYBEE, Joan L. From usage to grammar: the mind's response to repetition. In Language, 82(4): 711-733. 2006.

BYBEE, Joan L. Usage-based theory and exemplar representation. In Thomas Hoffman and Graeme Trousdale (eds.) The Oxford Handbook of Construction Grammar, pp. 49-69. Oxford University Press. 2013. 
BYBEE, Joan L. A functionalist approach to grammar and its evolution. In: Evolution of Communication 2: 249-278. 1998 (A)

BYBEE, Joan L. A view of phonology from a cognitive and functional perspective. In: Cognitive Linguistics 5-44: 285-305. 1994.

BYBEE, Joan L. Domain-general processes as the basis for grammar. In TALLERMAN, Maggie; GIBSON, Kathleen R. (eds.) The Oxford Handbook of Language Evolution, pp. 528536. Oxford: Oxford University Press. 2012

BYBEE, Joan L. Usage-based theory and grammaticalization. In NARROG, Heiko and HEINE, Bernd (eds.) The Oxford Handbook of Grammaticalization, 69-78. Oxford: Oxford University Press. 2011

BYBEE, Joan L.; BECKNER, Clay. Usage-based Theory. In Bernd Heine and Heiko Narrog (eds), The Oxford Handbook of Linguistic Analysis. Oxford: Oxford University Press. 827856. 2010

BYBEE, Joan L.; CACOULLOS, Rena T. Phonological and grammatical variation in exemplar models. In: Studies in Hispanic and Lusophone Linguistics 1(2): 399-413. 2008.

BYBEE, Joan L.; EDDINGTON, David. A usage-based approach to Spanish verbs of 'becoming. In Language 82(2): 323-355. 2006

BYBEE, Joan. Language universals and usage-based theory. In M.H. Christiansen, C. Collins, and S. Edelman (eds.), Language Universals. Oxford: Oxford University Press. 17-40. 2009

BYBEE, Joan. Usage-based phonology. Functionalism and Formalism In Linguistics VI, ed. by M. Darnell, E. Moravcsik, F. Newmeyer, M. Noonan, \& K. Wheatley. Amsterdam: John Benjamins 1999.

CALLOU, Dinah. Gramática, variação e normas. In: VIEIRA, Silvia R.; BRANDÃO, Silvia F. Ensino de gramática, descrição e uso. São Paulo: Contexto, 2009.

CAGLIARI, Luiz Carlos. "Entoação e Fonologia.” Estudos Linguísticos, jan - abr 2012: 8-22.

CASTILHO, Ataliba T. de, e Vanda Maria ELIAS. Pequena Gramática do português brasileiro. São Paulo: Contexto, 2012.

CASTILHO, Ataliba T. de. Nova gramática do português brasileiro. São Paulo: Contexto, 2010.

CEBRASPE, Centro Brasileiro de Pesquisa em Avaliação e Seleção e de Promoção de Eventos. Prova de redação do PAS, critérios de avaliação. Brasília, out. 2015.

CRISTÓFARO-SILVA, Thais. Descartando fonemas: a representação mental na Fonologia de Uso. In: Teoria Lingüística: Fonologia e outros temas. HORA, Dermeval; COLLISCHONN, Gisela. (org). PB: Ed. Universitária.UFPB.2002. pp 200-231

CROFT, William. Grammar: Functional Approaches. Albuquerque. Disponível em: http://www.unm.edu/ wcroft/Papers/Functionalism-IESBS2ed.pdf Acesso em: 30/03/2015.

CUNHA, Celso \& CINTRA Lindley. Nova gramática do português contemporâneo. - $3^{\mathrm{a} e d .}$ Rio de Janeiro: Nova Fronteira, 2001. 
CUNHA, Maria Angélica F. Funcionalismo. In: MARTELOTTA, Mário Eduardo (org.). Manual de linguística. São Paulo: Contexto, 2009.

CUNHA, Maria Angélica F.; BISPO, Edvaldo B.; SILVA, José Romerito. Linguística funcional centrada no uso e ensino de português. In: Revista Gragoatá. Niterói, n. 36, p. 80-104, 1. sem. 2014.

DAHLET, V. A pontuação e as culturas da escrita. Revista de Filologia Linguística Portuguesa, 2006, n. 8, p. 287-314.

FÁVERO, Leonor Lopes, Maria Lúcia da Cunha V. de Oliveira ANDRADE, e Zilda Gaspar Oliveira de AQUINO. Oralidade e escrita: perspectivas para o ensino de língua materna. São Paulo: Cortez, 2007 6a Edição.

FIGUEIREDO, Luiz Carlos. A redação pelo parágrafo. DF: Editora UnB, 1999.

GARCIA, Othon Moacyr. Comunicação em prosa moderna: aprenda a escrever, aprendendo a pensar. 26. Rio de Janeiro: FGV, 2006.

GIVÓN, Talmy. Functionalism and Grammar. Amsterdam/Philadelphia: John Benjamins Publishing Company, 1995.

HALLIDAY, Michael K.; HASAN, Ruqaiya. Cohesion in English. NY: Routledge, 2013 [1976] - Primeira edição publicada em 1976 por Pearson Education Limited.

HASPELMATH, Martin. "From purposive to infinitive - a universal path of grammaticization." In: Folia Linguistica Historica10.1-2: 287-310. 1989.

HIRST, Daniel; Di CRISTO, Albert. Intonation Systems: A Survey of Twenty Languages. Cambridge, Cambridge University Press. eds 1998.

HOPPER, Paul J. \& TRAUGOTT, Elizabeth C. Grammaticalization. Cambridge: Cambridge University Press. 2003

KENEDY, E; MARTELOTTA, M. E. T. A visão funcionalista da linguagem no século XX. In: CUNHA, Maria Angélica F.; OLIVEIRA, Mariangela R. de; MARTELOTTA, Mário Eduardo T. (Org.). Lingüística Funcional: teoria e prática. Rio de Janeiro: DP\&A / Faperj, 2003, v. , p. 17-28.

KERBRAT-ORECCHIONI, Catherine. Análise da Conversação: princípios e métodos. São Paulo: Parábola Editorial, 2006.

KHANSIR, Ali Akbar. Error Analysis and Second Language Acquisition. In: Theory and Practice in Language Studies Vol. 2, No. 5, pp. 1027-1032, May 2012.

KLEIMAN, Angela B. Letramento e suas implicações para o ensino de língua materna. In: Signo. Santa Cruz do Sul, v. 32 n 53, p. 1-25, dez, 2007.

$\mathrm{KOCH}$ Introdução à linguística textual: trajetória e grandes temas. São Paulo: Martins Fontes, 2004 [2006].

KOCH, Ingedore V. A inter - ação pela linguagem. 10. ed. São Paulo: Contexto, 2007.

LAKOFF, George. The Cognitive Science of Presocratic Metaphysics. 1994. 
LEHMANN, Christian. Thoughts on grammaticalization. Second, revised edition July 2002

LEMLE, Miriam. Guia teórico do alfabetizador. São Paulo: Ática, 2011 (Princípios, 104).

LEVINSON, Stephen C. Pragmática. São Paulo: Martins Fontes, 2007.

MADUREIRA, Sandra. Entoação e síntese de fala: modelos e parâmetros. (p. 53 - 65) In: SCARPA, Ester M. (org.) Estudos de prosódias. São Paulo: Editora da Unicamp, 1999.

MARCHETTI, Greta; COSTA Cibele L.; SOARES, Jairo J. B.; TAKEUCHI, Márcia. Para viver juntos português. - $3^{\mathrm{a}}$ ed. - São Paulo: Edições SM, 2014.

MARCONI, Marina de A.; LAKATOS, Eva Maria. Fundamentos de metodologia científica. $5^{\text {a }}$ ed. São Paulo: Atlas, 2003.

MARTINS, Dileta S. \& ZILBERKNOP, Lúbia S. Português Instrumental: de acordo com as atuais normas da ABNT. - 29 ed. - São Paulo: Atlas, 2010.

MATEUS, Maria H. M. Estudando a melodia da fala: traços prosódicos e constituintes prosódicos. Em: atas do Encontro sobre o ensino das línguas e a linguística APL e ESE de Setúbal, 2004. Disponível em http://www.iltec.pt/pdf/wpapers/2004-mhmateus-prosodia.pdf Acesso em : 22 de março de 2009.

MATEUS

A contribuição do estudo dos sons para a aprendizagem da língua. Em: Atas do $7^{\circ}$ Encontro Nacional da APP: Saber Ouvir / Saber Falar, 2007. Disponível em http://www.iltec.pt/pdf/wpapers/2007-mhmateus-congresso7-app.pdf Acesso em: 22 de março de 2009

MIRANDA, Izabel Cristina C.; GUIMARÃES, Daniela Mara. O. Contribuição dos modelos multirrepresentacionais à variação fonológica. In Letrônica, Porto Alegre, v. 6, n. 1, p. 214-227, jan. $\quad / \quad$ jun., $2013 . \quad$ Disponível em http://revistaseletronicas.pucrs.br/ojs/index.php/letronica/article/viewFile/13413/10101 Acesso em 25 de agosto de 2015.

MORAES

\& COLAMARCO, Manuela. Você está pedindo ou perguntando? Uma análise entonacional de pedidos e perguntas na fala carioca. Rev. Est. Ling., Belo Horizonte, v. 15, n. 2, p. 113-126, jul./dez. 2007.

MORAES, João. The pitch accents in Brazilian Portuguese: analysis by synthesis. 2008. Disponível em http://aune.lpl.univ-aix.fr/ sprosig/sp2008/papers/8inv.pdf Acesso em 21 de abril de 2009.

NOLAN, Francis. Intonation. In: B. Aarts \& A. McMahon (eds), Handbook of English Linguistics. $\quad$ Oxford: $\quad$ Blackwell, $2006 . \quad$ Disponível em http://www.ling.cam.ac.uk/francis/FN_inton_prepub.pdf

PERINI, Mário. A. Gramática do português brasileiro. 1. ed. São Paulo: Parábola Editorial, 2010. v. 1.368p .

PIERREHUMBERT, J. The Phonology and Phonetics of English Intonation. Ph.D. Thesis, Mass., MIT, Cambridge, 1980.

PIERREHUMBERT, Janet B. Phonetic diversity, statistical learning, and acquisition of phonology. In Language and speech, v. 46, p. 115-154, 2003. 
POSSENTI, Sírio. Por que (não) ensinar gramática na escola / Sírio Possenti - Campinas, SP: Mercado de Letras: Associação de Leitura do Brasil, 1996. (Coleção Leituras no Brasil)

POZNAN, Wiktor J. A Review of Intonation Systems: A Survey of Twenty Languages. Phonetica 57:70-75 2000.

RODRIGUES, Violeta V. Advérbios aspectuais de valor conectivo. VIII CONGRESSO NACIONAL DE LINGÜÍSTICA E FILOLOGIA, 2004.

SILVA, Leila N. da. Ensino e aprendizagem da paragrafação: concepções de práticas de professores e conhecimentos de seus alunos. Maio de 2014. 411 fl. Tese de Doutorado. Universidade Federal de Pernambuco. Programa de Pós-graduação em Educação, 2014.

TENANI, Luciani. A segmentação não-convencional de palavras em textos do ciclo ii do ensino fundamental. In: Revista da ABRALIN, v.10, n.2, p. 91-119, jul./dez. 2011 Disponível em http://ojs.c3sl.ufpr.br/ojs/index.php/abralin/article/viewFile/32061/20400 acesso 31/07/2015

TOMASELLO, Michael. The usage-based theory of language acquisition. Artigo disponível em https://www.princeton.edu/ adele/LIN_106:_UCB_files/Tomasello-BavinChapter09.pdf Acesso em: 20 de out. 2015.

TORRENT, Tiago T. Usage-based models in linguistics: an interview with Joan Bybee. Revista LinguíStica / Revista do Programa de Pós-Graduação em Linguística da Universidade Federal do Rio de Janeiro. Volume 8, número 1, junho de 2012. ISSN 1808-835X 1. [http://www.letras.ufrj.br/poslinguistica/ revistalinguistica]

TRAUGOTT, Elizabeth C. "Grammaticalization", in LURAGHI Silvia; BUBENIK Vit, eds., Continuum Companion to Historical Linguistics, 269-283. London: Continuum Press. 2010

TRAVAGLIA, Luiz Carlos. Gramática ensino plural. 2a ed. São Paulo: Cortez, 2004. 
Anexos 


\section{Anexo 1 - O questionário}

Idade:

Gosta de ler?

Quantos livros por mês você lê?

Você tem o hábito de ler na internet?

Se sim, o quê?

Com base em seu ponto de vista e em seus conhecimentos adquiridos até este momento de sua vida escolar, responda as questões abaixo.

1. Você gosta de produzir textos?
( ) $\operatorname{Sim}$
( ) Não
( ) Mais ou menos

2. Que tipo de textos você mais gosta de produzir? Marque apenas uma alternativa.

( ) Narrativos - que contam histórias.

( ) Argumentativos - que apresentam opiniões.

( ) Diários - que contam suas experiências e sentimentos.

( ) Nenhuma das respostas anteriores (N.R.A.).

3. Para você, o que é o PARÁGRAFO?

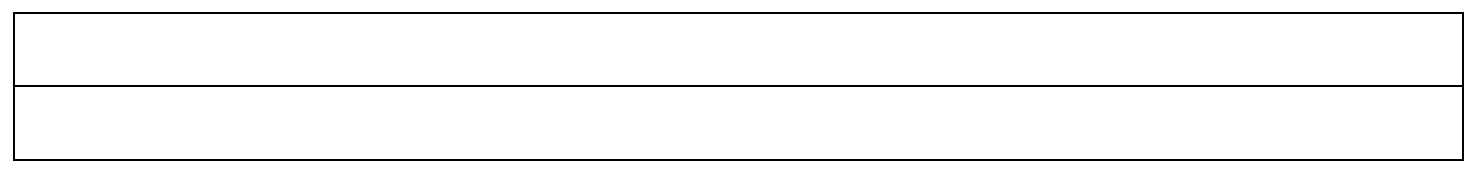

4. Em sua opinião, para que serve o PARÁGRAFO?

5. Como é organizado o PARÁGRAFO? 
6. Das opções abaixo, marque apenas uma alternativa. Em seguida, explique a razão de sua escolha.

a) ( ) O parágrafo só existe nos textos falados (em conversas, aulas, palestras, diálogos de filmes etc.).

b) ( ) O parágrafo existe nos textos escritos e nos textos falados.

c) ( ) O parágrafo só existe nos textos escritos.

d) ( ) O parágrafo não existe.

Justificativa.

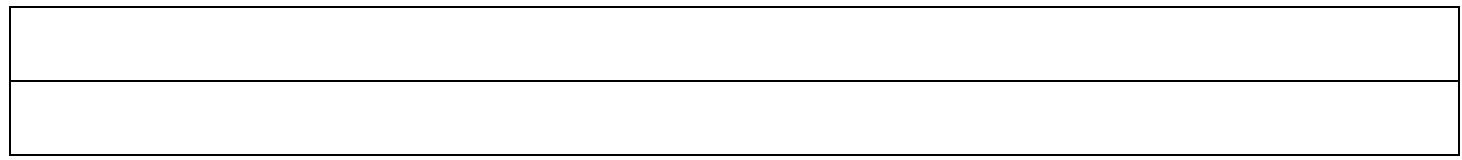

7. Você gosta que as pessoas contem ou leiam histórias para você?

( ) Sim ( ) Não

Por quê?

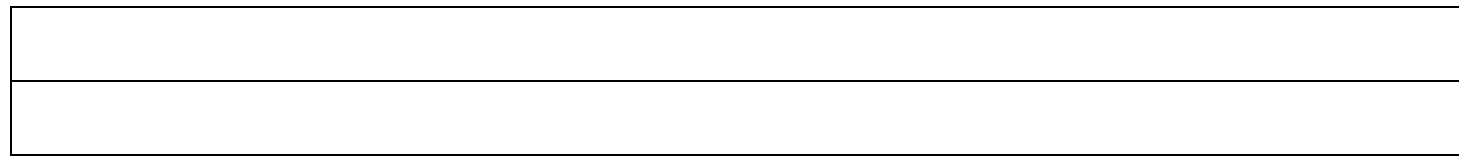

8. Em sua opinião, o que são os sinais de pontuação (vírgula, ponto final, ponto de interrogação, reticências, ponto de exclamação e ponto e vírgula)?

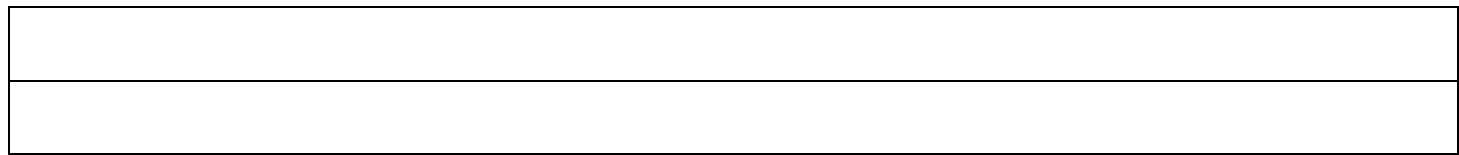

9. Em sua opinião, para que servem os sinais de pontuação?

10. Para que você costuma usar a vírgula e o ponto final em seus textos?

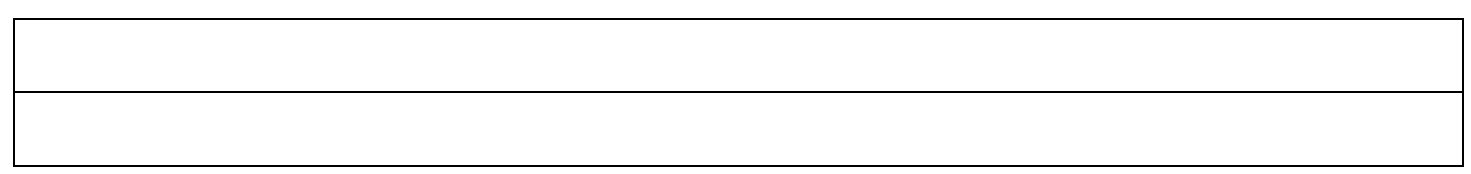


11. Sobre o uso da vírgula e do ponto final, marque apenas a única alternativa com a qual você concorda. Em seguida, explique a razão de sua escolha.

a) ( ) O ponto final e a vírgula só existem nos textos falados.

b) ( ) O ponto final e a vírgula existem nos textos escritos e nos textos falados.

c) ( ) O ponto final e a vírgula só existem nos textos escritos.

d) ( ) O ponto final e a vírgula não existem.

Justificativa.

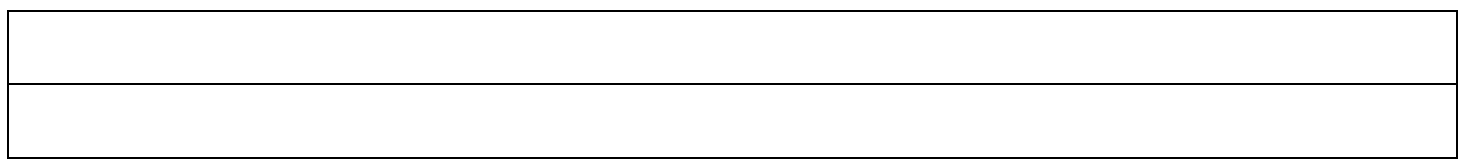

12. Escreva um pequeno texto (entre 10 e 15 linhas), apresentando sua opinião sobre o tema proposto na pergunta abaixo.

EDUCAÇÃO NO BRASIL: O QUE PRECISA MUDAR?

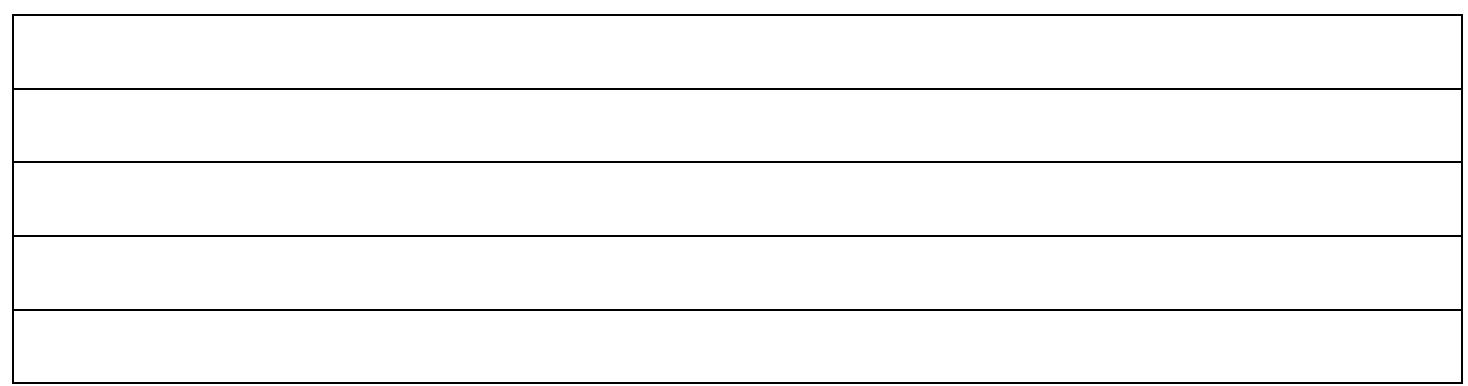


Anexo 2 - Livro Didático "Para viver juntos"

\section{SUMÁRIO}

\begin{tabular}{|c|c|c|}
\hline 61 & Q25 Romance de aventura & 11 \\
\hline Leitura? & 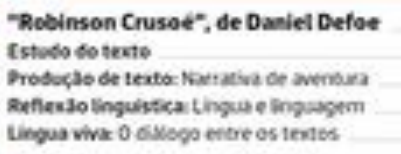 & $\begin{array}{l}12 \\
15 \\
20 \\
22 \\
27\end{array}$ \\
\hline Leitura 2 &  & $\begin{array}{l}28 \\
31 \\
34 \\
36 \\
40 \\
41\end{array}$ \\
\hline
\end{tabular}

\subsection{Conto popular}

Leltura 1 "O marido da Mase-digua", Setuls da Camara Cascudo

tstudo do terito



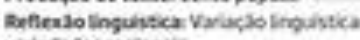

viriestades reglonat

Lingua viva $A$ valacso inguissica ef

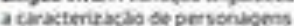

Leitura 2 "A moқa que pegoes a serpente",

\section{de Tres Pinguilly}

tstodio to trats

Predocle de texto concte popdar.

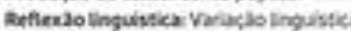

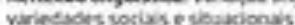

Unguaviva Linguagem e actequaclo

a sifuklo dscurbi

puestlets de escrits

Enconbo consonartate digats

\section{9}

Oratissde

Belato de Nisteria famalar

82

\begin{tabular}{|c|c|c|}
\hline \multicolumn{2}{|c|}{5 es: História em quadrinhos } & 85 \\
\hline \multirow[t]{5}{*}{ Leitura 1} & "Ze Pequeno Voluntario", & 85 \\
\hline & totudo do texito & 87 \\
\hline & Frodoctse de teato Histisris en euadrinhos & 92 \\
\hline & Nefieazo lngubstica: S. Dostartivo & 94 \\
\hline & $\begin{array}{l}\text { Ungua viva } 0 \text { substantivo em } \\
\text { diastificados e potmas }\end{array}$ & 201 \\
\hline \multirow[t]{8}{*}{ teitura 2} & "A estrela misteriosa", de Hergé & 102 \\
\hline & Estado to vento & 104 \\
\hline & Droducha de tecta inaska om quadrinhot & 106 \\
\hline & Deflesio Inguatica o westardivo & \\
\hline & e saas fleodes & 108 \\
\hline & Lingua wive o roter semsetice & \\
\hline & da fiexio dos westanteves & 173 \\
\hline & Questles de escrita Segaracas de slubas & Ho \\
\hline
\end{tabular}

\begin{tabular}{|c|c|c|}
\hline & A Noticia & 121 \\
\hline \multirow[t]{5}{*}{ Leitura 1} & $\begin{array}{l}\text { "Ziogàs substitui lenha no Sertäo", } \\
\text { de Verbinica Falclos }\end{array}$ & 122 \\
\hline & Estode do texto & 124 \\
\hline & Producta ce tente: Nosion & 128 \\
\hline & Refiexse linguiaties Adirtivo & 130 \\
\hline & Linpua viva 0 adfetivo ru nodicla & 135 \\
\hline
\end{tabular}

Leitura 2 "Grande concentraçlo de unubus

e de andorinhas compromete energia

em Parintins", de Elaire Farias

Carodo do terto

140

Reflexse langistica 0 adjesive

esuar frobs

142

tingua viva o valar semincico

datecio dos adjetives.

Qutures de escota stibationica

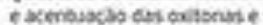

proparoniboras.

Orasidade

Dilage em roteirs de ciedm

153

E veré Relato de viagem e diário de viagem

Leitura 1 "Partir" "Uma foca solitirla".

de Amyr Klink

Espudes do testo

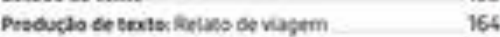

Reflexds Inguistica Actipo e rumera $\quad 166$

Ungua viva A, determinxto

ea indecerninacle

Leitura 2 "Prolets Expeciçso Estrada fieat $\mathrm{r}$.

de Gusherne Chaves Correa

Figueiredo

ritudo do teratg



Reflex so lingulatica redriekso $\quad 178$

Lingou viva: a intertection

eatcinstraxtlo de sertipos. 181

Qutiobes oe escoto:



Oralldade

Eemunicate 186

Figura 53 - Livro didático "Para viver juntos", para o sexto ano, 2014, página 8. 


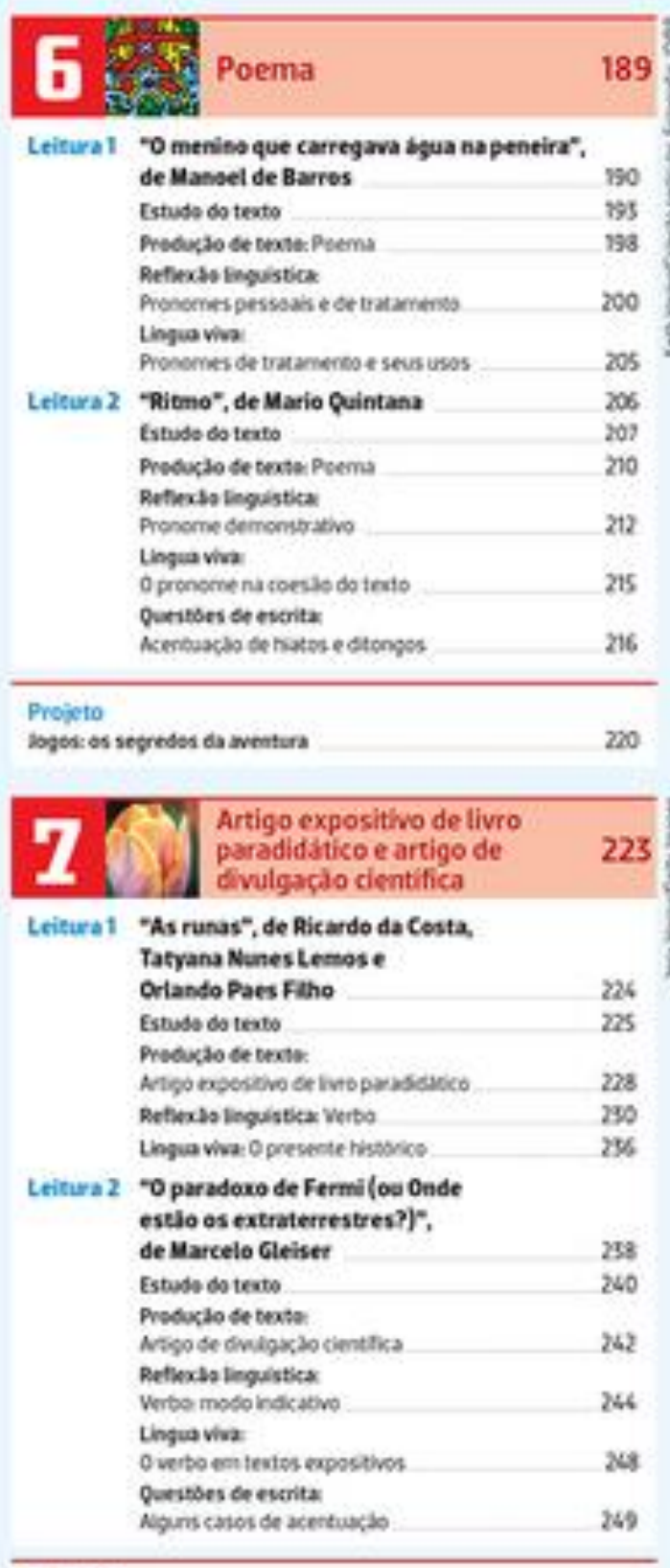

\begin{tabular}{|c|c|c|}
\hline in & Entrevista & 257 \\
\hline Leitura ! & $\begin{array}{l}\text { Entrevista cem Fernanda Takal } \\
\text { (Pato Fu), de Asdre Azentha }\end{array}$ & 88 \\
\hline & Estudo do teato & 260 \\
\hline &  & 264 \\
\hline & Reflexas inguastica & \\
\hline & Yerber modo sibienton & 266 \\
\hline & Lingua vilaz o werbo na construclo & $x 0$ \\
\hline
\end{tabular}

Leitura 2 Entrevista con Carlos Saldarhat "A preducio brasiletra é pouco centhedda ts forx",

de Catarina Cicarelli 210

Esoudo do teato 275

Producho et texte: Enorests. 276

Reflexso lingustica

Veros formas nitainis 278

Linguavive Ogeruisisns 281

Quersses de escrita:

Emonoso doge soi $\quad 292$

Oralidade
sarnat falase
285

\begin{tabular}{|c|c|c|}
\hline 1 & Revisão & 289 \\
\hline Leitura 1 & $\begin{array}{l}\text { "Piratas sem pledade..", } \\
\text { de Suely Mendes Brazaso } \\
\text { Ertodo do texto }\end{array}$ & $\begin{array}{l}290 \\
293\end{array}$ \\
\hline Leitura 2 & 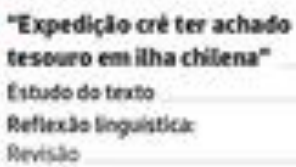 & $\begin{array}{l}294 \\
296 \\
298\end{array}$ \\
\hline $\begin{array}{l}\text { Beferenci } \\
\text { Foners da }\end{array}$ & $\begin{array}{l}\text { is biblogrificas } \\
\text { internet }\end{array}$ & $\begin{array}{l}302 \\
303\end{array}$ \\
\hline
\end{tabular}

Orallade

Exposicto oral

254
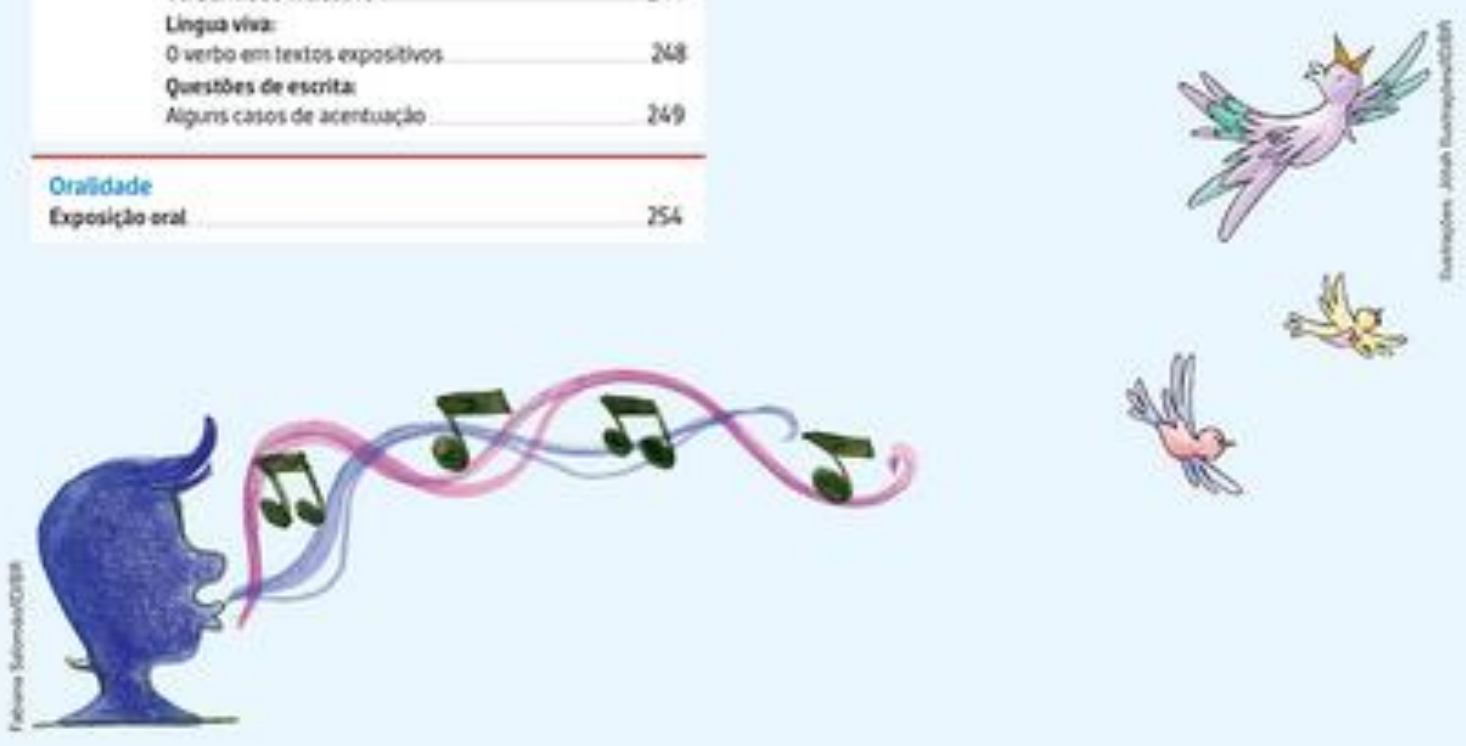

Figura 54 - Livro didático "Para viver juntos", para o sexto ano, 2014, página 9. 


\section{Anexo 3 - Tabela de Critérios de Análise dos dados}

\begin{tabular}{|c|c|}
\hline Escrita formal & \\
\hline 1a) Acentuação & 113 \\
\hline 1b) Concordância Nominal & 19 \\
\hline 1b) Concordância Verbal & 28 \\
\hline 1c) Ortografia & 103 \\
\hline 2. Tipologia e Proposta & 01 \\
\hline 3. Paragrafação & \\
\hline 3a) Texto formado por um parágrafo. & 07 \\
\hline 3b) Parágrafo composto por uma só frase. & 46 \\
\hline 3c) Parágrafo composto por frases longas. & 21 \\
\hline $\begin{array}{l}\text { 3d) Parágrafo com mais de uma ideia sendo } \\
\text { desenvolvida. }\end{array}$ & 8 \\
\hline 4. Coesão & \\
\hline 4a) Uso inadequado de conectivos. & 29 \\
\hline 4b) Uso inadequado de tempos verbais. & 22 \\
\hline 4c) Truncamento de informações & 49 \\
\hline 4d) Repetição de palavras. & 73 \\
\hline 4e) Colocação pronominal (oblíquos). & 38 \\
\hline $\begin{array}{l}\text { 4f) Regência - nominal e verbal (uso do acento } \\
\text { indicativo de crase). }\end{array}$ & 37 \\
\hline 4g) Uso de "coisa" como elemento de retomada. & 13 \\
\hline $\begin{array}{l}\text { 4i) uso de termos de referência sem antecedente } \\
\text { determinado. }\end{array}$ & 20 \\
\hline 5. Pontuação & \\
\hline 5a) Uso de vírgula entre sujeito e verbo. & 13 \\
\hline 5b) Uso de vírgula entre verbo e objetos. & 05 \\
\hline $\begin{array}{l}\text { 5c) Ausência de vírgula para isolar orações, } \\
\text { locuções ou expressões adverbiais deslocadas. }\end{array}$ & 96 \\
\hline $\begin{array}{l}\text { 5d) Ausência de vírgulas entre orações e termos } \\
\text { intercalados. }\end{array}$ & 26 \\
\hline $\begin{array}{l}\text { 5e) Ausência de vírgulas antes de orações } \\
\text { subordinadas. }\end{array}$ & 30 \\
\hline $\begin{array}{l}\text { 5f) Ausência de vírgulas em frases com alteração de } \\
\text { sujeito. }\end{array}$ & 26 \\
\hline $\begin{array}{l}\text { 5g) Ausência de vírgula antes de "mas", "porém" } \\
\text { etc. em coordenação sindética. }\end{array}$ & 34 \\
\hline 5h) Ausência de ponto final após declaração inicial. & 27 \\
\hline $\begin{array}{l}\text { 5i) Uso de vírgula antes de último item de } \\
\text { enumeração de itens simples (ex.: uva, maçã, } \\
\text { banana). }\end{array}$ & 28 \\
\hline $\begin{array}{l}\text { 5j) Ausência de vírgula antes de oração de valor } \\
\text { explicativo. }\end{array}$ & 58 \\
\hline $\begin{array}{l}\text { 5k) Ausência de vírgulas antes de orações } \\
\text { coordenadas alternativas. }\end{array}$ & 06 \\
\hline
\end{tabular}

